HILTON KENJI TAKAHASHI

\title{
MECANISMOS ENVOLVIDOS NA MORTE E SOBREVIVÊNCIA DE LINFÓCITOS EXPOSTOS AO ÁCIDO PALMÍTICO
}

Tese apresentada ao Programa de PósGraduação em Fisiologia e Biofísica do Instituto de Ciências Biomédicas da Universidade de São Paulo, para obtenção do Título de Doutor em Ciências.

São Paulo

2010 
HILTON KENJI TAKAHASHI

\section{MECANISMOS ENVOLVIDOS NA MORTE E SOBREVIVÊNCIA DE LINFÓCITOS EXPOSTOS AO ÁCIDO PALMÍTICO}

Tese apresentada ao Programa de PósGraduação em Fisiologia e Biofísica do Instituto de Ciências Biomédicas da Universidade de São Paulo, para obtenção do Título de Doutor em Ciências.

Área de concentração: Fisiologia Humana

Orientador: Prof. Dr. Rui Curi

São Paulo

2010 
DADOS DE CATALOGAÇÃO NA PUBLICAÇÃO (CIP)

Serviço de Biblioteca e Informação Biomédica do Instituto de Ciências Biomédicas da Universidade de São Paulo

(c) reprodução total

Takahashi, Hilton Kenji.

Mecanismos envolvidos na morte e sobrevivência de linfócitos expostos ao ácido palmítico / Hilton Kenji Takahashi. -- São Paulo, 2010.

Orientador: Rui Curi.

Tese (Doutorado) - Universidade de São Paulo. Instituto de Ciências Biomédicas. Departamento de Fisiologia e Biofísica. Área de concentração: Fisiologia Humana. Linha de pesquisa: Fisiologia Celular.

Versão do título para o inglês: Mechanisms involved in death and survival of lymphocytes exposed to palmitic acid.

Descritores: 1. Apoptose 2. Linfócito 3. Linhagem Celular 4. Ácido graxo 5. Metabolismo celular 6. Insulina I. Curi, Rui II. Universidade de São Paulo. Instituto de Ciências Biomédicas. Programa de PósGraduação em Fisiologia Humana. III. Título. 


\section{UNIVERSIDADE DE SÃO PAULO \\ INSTITUTO DE CIÊNCIAS BIOMÉDICAS}

Candidato(a):

Título da Tese:

Mecanismos envolvidos na morte e sobrevivência de linfócitos expostos ao ácido palmítico.

Hilton Kenji Takahashi.

Orientador(a):

A Comissão Julgadora dos trabalhos de Defesa da Tese de Doutorado, em sessão pública realizada a ................., considerou

\section{( ) Aprovado(a) \\ ( ) Reprovado(a)}

\begin{tabular}{|c|c|}
\hline Examinador(a): & $\begin{array}{l}\text { Assinatura: } \\
\text { Nome:........ } \\
\text { Instituição:. }\end{array}$ \\
\hline Examinador(a): & $\begin{array}{l}\text { Assinatura:. } \\
\text { Nome:....... } \\
\text { Instituição:. }\end{array}$ \\
\hline Examinador(a): & $\begin{array}{l}\text { Assinatura: } \\
\text { Nome:...... } \\
\text { Instituição:. }\end{array}$ \\
\hline Examinador(a): & $\begin{array}{l}\text { Assinatura: } \\
\text { Nome:...... } \\
\text { Instituição:. }\end{array}$ \\
\hline Presidente: & $\begin{array}{l}\text { Assinatura: } \\
\text { Nome:...... } \\
\text { Instituição:. }\end{array}$ \\
\hline
\end{tabular}


Aos meu pais pelo todo suporte, incentivo e confiança , À Jamille por estar sempre ao meu lado, Ao amigo Rui Curi, pela oportunidade e ter acreditado em mim mais do que eu prórpio 


\section{AGRADECIMENTOS}

Aos amigos do laboratório de Fisiologia Celular pelo aprendizado, colaborações e convivência.

Aos técnicos do laboratório Roberto "Bob" e Geraldina pelo suporte e pela manutenção da estrutura para o andamento dos experimentos.

Ao secretário de pós-graduação José Maria por todo o auxílio e conselhos.

Ao prof. Phillip Newsholme pelo convite e oportunidade de trabalhar em seu laborátorio

Ao staff do laboratório da University College Dublin: Maurício, Josiane, Manuella, Marc, Rodolfo, Niammh, Sarah, Celline, Mia e Peter.

Aos funcionários do biotério Cláudio e Vilson e aos animais de experimentação utilizados

À CAPES, CNPq e FAPESP pelo suporte financeiro 
"Sciece is an essentially anarchic enterprise"

Paul Feyerabend 


\section{RESUMO}

TAKAHASHI, H. K. Mecanismos envolvidos na morte e sobrevivência de linfócitos expostos ao ácido palmítico. 2010. 188 f. Tese (Doutorado em Fisiologia Humana) - Instituto de Ciências Biomédicas, Universidade de São Paulo, São Paulo, 2010.

Os ácidos graxos podem atuar na via de sinalização da morte celular programada, ativando e/ou desativando sinais que regulam este processo. Células Jurkat de linhagem de linfócitos-T, humano, foram tratadas com concentrações subtóxicas de ácido palmítico (PA) (50, 100 e $150 \mu \mathrm{M})$ e foi avaliada a ativação de vias de sinalização de morte e de sobrevivência. Verificou-se que o PA induziu apoptose de maneira dose-dependente. A exposição ao PA induziu despolarização da membrana mitocondrial e extravasamento do citocromo c. Foi observada ativação de proteínas da família das MAPK (JNK, p38 e ERK), caspases 3 e 9 e da PKC-ס, envolvidas na via de apoptose. O tratamento com PA aumentou a produção de espécies reativas de oxigênio e de óxido nítrico. A exposição das células Jurkat ao PA elevou a expressão do receptor de insulina (IR) e GLUT-4 na membrana plasmática. $O$ mesmo efeito foi observado em linfócitos humanos obtidos de doadores saudáveis expostos ao PA e de ratos em jejum. Correlação positiva foi obtida entre fragmentação de DNA e a expressão de IR e GLUT-4. O tratamento das células Jurkat com insulina após o tratamento com PA promoveu um aumento da fosforilação de IR, IRS-1 e de Akt, o que demonstra ativação da via de sinalização da insulina. Um aumento da captação de glicose foi observado na presença de PA, mas observou-se diminuição da sua oxidação e aumento do acúmulo deste em triacilgliceróis, fosfolípides e ésteres de colesterol. Assim a via de sinalização da insulina e o metabolismo de glicose não oxidativo são estimulados como parte de uma coordenada resposta de sobrevivência de linfócitos expostos ao PA em baixas concentrações mas em altas concentrações o ácido graxo induz morte das células.

Palavras-chave: Apoptose. Ácido graxo. Linfócito. Linhagem celular. Metabolismo celular. Insulina 


\begin{abstract}
TAKAHASHI, H. K. Mechanisms involved in death and survival of lymphocytes exposed to palmitic acid. 2010. 188 p. Ph. D. Thesis (Human Phisyology) - Instituto de Ciências Biomédicas, Universidade de São Paulo, São Paulo, 2010.
\end{abstract}

Fatty acids affect the programmed cell death signaling pathway activating or deactivating signals that regulate this process. Jurkat cells, a human Tlymphocyte lineage, were treated with sub-lethal concentrations of palmitic acid (PA) $(50,100$ e $150 \mu \mathrm{M})$ and the activation of cell death and survival signaling pathways were investigated. PA induced apoptosis in a dose dependent manner. Exposure of the cells to PA induced mitochondrial membrane depolarization and release of cytochrome $\mathrm{c}$ from mitochondria and activated members of the MAPK family (JNK, p38 e ERK), caspases 3 and 9 and PKC- $\delta$, responsible for the activation of the apoptosis pathway. PA treatment led to increased production of reactive oxygen species and nitric oxide. Jurkat cells exposed to PA showed increased insulin receptor (IR) and GLUT-4 expression in the plasma membrane. Similar effect was observed in human lymphocytes obtained from healthy donors and lymphocytes from fasted rats. A correlation was found between the proportion of cells with DNA fragmentation and expression levels of both IR and GLUT-4. Insulin treatment of Jurkat cells after PA treatment promoted the phosphorylation of IR, IRS-1 and Akt, which demonstrates the involvement of the insulin signaling pathway. Glucose uptake was increased in the presence of PA, however, its oxidation was diminished. Also an increase of the accumulation of triacylglycerol, phospholipids and cholesterol ester was observed. Therefore, insulin signaling and non oxidative glucose metabolism are stimulated as a part of a coordinated response to survival of lymphocytes exposed to low concentration of PA but in high concentration this fatty acid induces cell death.

Keywords: Apoptosis. Lymphocyte. Cell lineage. Fatty acid. Cell Metabolism. Insulin 
1 INTRODUÇÃO

1.1 MORTE CELULAR 12

1.1.2 Morte celular programada $\quad 13$

1.1.3 Apoptose clássica $\quad 15$

1.1.3.1 Indução 16

1.1.3.1.1 Via extrínseca 16

1.1.3.1.2 Via intrínseca 19

1.1.3.2 Decisão $\quad 21$

1.1.3.3 Execução $\quad 24$

1.1.4 Apoptose independente de caspases 26

$\begin{array}{ll}\text { 1.1.5 Morte por autofagia } & 27\end{array}$

1.1.6 Morte por necrose $\quad 29$

1.2 METABOLISMO E FUNÇÃO DE LINFÓCITOS T 32

1.2.1 Linfócitos $T$

1.2.2 Metabolismo de linfócitos $T$

1.3 OS ÁCIDOS GRAXOS $\quad 40$

1.3.1 Classificação de ácidos graxos $\quad 40$

1.3.2 Metabolismo e função de ácidos graxos 42

1.3.3 Modulação da função celular por ácidos graxos $\quad 44$

2 PROPOSTA DO ESTUDO 46

3 OBJETIVOS

4 MATERIAL E MÉTODOS 48

4.1 LINHAGENS CELULARES 48

4.2 OBTENÇÃO E PREPARAÇÃO DE LINFÓCITOS HUMANOS 48

4.3 OBTENÇÃO E PREPARAÇÃO DE LINFÓCITOS DE RATOS 48

4.4 TRATAMENTO DAS CÉLULAS 49

4.5 ANÁLISE MORFOLÓGICA 49

4.6 AVALIAÇÃO DAATIVIDADE MITOCONDRIAL 49

4.7 ANÁLISE DA FRAGMENTAÇÃO DE DNA 50

4.8 ENSAIO DA ATIVIDADE DA ENZIMA 
LACTATO DESIDROGENASE (LDH)

4.9 AVALIAÇÃO DA DESPOLARIZAÇÃO DA

MEMBRANA MITOCONDRIAL

4.10 AVALIAÇÃO DA DISTRIBUIÇÃO DO CITOCROMO C 51

4.11 WESTERN BLOTTING 52

4.12 IMUNOPRECIPITAÇÃO 53

4.13 ENSAIO DO RETARDAMENTO DA MOBILIDADE

ELETROFORÉTICA (EMSA) PARA O NF-kB

4.14 AVALIAÇÃO DA ABUNDÂNCIA DO RECEPTOR DE INSULINA

E DE GLUT-4 POR CITOMETRIA DE FLUXO

4.15 DETERMINAÇÃO DA CAPTAÇÃO DE GLICOSE 54

4.16 ENSAIO DA OXIDAÇÃO DE D-[U- $\left.{ }^{14} \mathrm{C}\right]$ GLICOSE

4.17 DETERMINAÇÃO DO CONSUMO DE GLICOSE E DE GLUTAMINA E DA PRODUÇÃO DE LACTATO E GLUTAMATO 55

4.18 ANÁLISE QUALITATIVA DO CONTEÚDO DE TRIACILGLICERÓIS 57

4.19 DETERMINAÇÃO DO ACÚMULO INTRACELULAR

DE LIPÍDEOS NEUTROS 57

4.20 INCORPORAÇÃO DE $\left[{ }^{14} \mathrm{C}\right]$-PALMITATO EM FRAÇÕES LIPÍDICAS 57

4.21 DETERMINAÇÃO DA COMPOSIÇÃO DE ÁCIDOS GRAXOS

EM CÉLULAS JURKAT E PLASMA DE RATOS

4.22 QUANTIFICAÇÃO DE ÁCIDOS GRAXOS LIVRES

DE PLASMA DE RATOS 58

4.23 DETERMINAÇÃO DA PRODUÇÃO DE SUPERÓXIDOS 59

4.24 ENSAIO DA PRODUÇÃO DE PERÓXIDO DE HIDROGÊNIO 59

4.25 ENSAIO DA PRODUÇÃO DE NITRITO 59

4.26 QUANTIFICAÇÃO DO CONTEÚDO INTRACELULAR DE GLUTATIONA REDUZIDA (GSH) E OXIDADA (GSSG) 60

4.27 ANÁLISE ESTATÍSTICA $\quad 61$

5 RESULTADOS $\mathbf{6 2}$

5.1.CARACTERIZAÇÃO DA MORTE CELULAR 62

\subsubsection{Efeito da incubação com PA sobre a fragmentação}


5.1.2 Efeito do PA sobre a atividade mitocondrial nas células Jurkat

5.1.3 Efeito do PA sobre a proporção de células Jurkat em Necrose

5.1.4 Efeito do PA sobre a despolarização da membrana mitocondrial

5.1.5 Liberação do citocromo c da mitocôndria 66

5.1.6 Avaliação da ativação das caspases 3 e 9

5.1.7 Avaliação da ativação de PKC-ठ 69

5.1.8 Efeito do PA sobre a via de sinalização das MAPK na morte das células Jurkat

5.2 AVALIAÇÃO DO EFEITO DO PA SOBRE O

ESTRESSE OXIDATIVO

5.2.1 Efeito do tratamento com PA na produção de superóxido em células Jurkat.

5.2.2 Efeito do PA sobre a produção de peróxido de hidrogênio em células Jurkat

5.2.3 Efeito do PA sobre a produção de nitrito em células Jurkat

5.2.4 Efeito do PA sobre a expressão da proteína iNOS 75

5.2.5 Quantificação de GSH e GSSG

5.3 AVALIAÇÃO SOBRE O PERFIL LIPÍDICO

5.3.1 Avaliação morfológica de células Jurkat tratadas com PA

5.3.2 Avaliação do conteúdo de lípides neutros em células Jurkat tratadas com PA

5.3.3 Incorporação do PA nas frações de lipídios intracelular

5.3.4 Análise da composição de ácidos graxos em

células tratadas com PA

5.4 EFEITO DO PA SOBRE O METABOLISMO DOS LINFÓCITOS

5.4.1 Efeito do PA sobre a expressão dos receptores de insulina e de GLUT-4

5.4.2 Efeito do PA sobre a via de sinalização de insulina

5.4.3 Efeito do PA sobre o metabolismo de glicose nas células Jurkat 
5.4.4 Avaliação do consumo de glicose e glutamina e da produção de lactato e glutamato

5.4.5 Avaliação do efeito do tratamento com PA

na expressão e ativação da AMPK

5.4.6 Efeito do AICAR sobre a fragmentação das células Jurkat tratadas com PA.

5.4.7 Efeito da insulina sobre a fragmentação das células Jurkat tratadas com PA

5.5 AVALIAÇÃO DO EFEITO DO PA SOBRE

LINFÓCITOS HUMANOS

5.6 AVALIAÇÃO DO EFEITO DO JEJUM SOBRE

LINFÓCITOS DE RATOS

5.6.1 Quantificação de ácidos graxos livres no plasma 102

5.6.2 Avaliação do perfil de ácidos graxos do plasma 103

5.6.3 Avaliação do efeito do PA sobre linfócitos de ratos 104

5.7 AVALIAÇÃO DOS EFEITOS DOS INDUTORES DE APOPTOSE, ESTAUROSPORINA E ETOPOSIDE SOBRE A

EXPRESSÃO DE IR E GLUT-4 105

5.8 AVALIAÇÃO DAATIVIDADE DO NF-kB EM CÉLULAS JURKAT 107

6 DISCUSSÃO 108

7 CONCLUSÃO 118

REFERÊNCIAS

ANEXO 153 


\section{INTRODUÇÃO}

\subsection{MORTE CELULAR}

Os primeiros estudos sobre morte celular datam do início do século XIX, mas apenas em 1951, Glücksman definiu que este processo é um componente normal no desenvolvimento do organismo. A morte de células é fator determinante no desenvolvimento e manutenção do organismo, seja na retirada de células defeituosas, na manutenção do controle do número de células bem como na formação de estruturas como no desenvolvimento dos dedos das mãos no embrião. Tal processo é fisiológico e geneticamente regulado, opondo-se à necrose em que a morte ocorre frente a uma injúria, que leva ao extravazamento do conteúdo celular induzindo resposta inflamatória (BAEHRECKE, 2002)

A morte celular é definida como uma perda irreversível da integridade da membrana plasmática. Historicamente, três tipos de morte celular foram distinguidos em células de mamíferos por critérios morfológicos. A morte celular do tipo I, conhecida hoje como apoptose, é definida por mudanças características na morfologia nuclear, incluindo condensação da cromatina (piquenose) e sua fragmentação (cariorrequise), encolhimento da célula e a formação de corpos apoptóticos contendo material nuclear ou citoplasmático. Estas mudanças ocorrem antes que a membrana plasmática perca sua integridade. A morte celular do tipo II é caracterizada pelo acúmulo massivo de vacúolos autofágicos no citoplasma. A morte celular do tipo III, conhecida como necrose, é caracterizada pela dilatação de organelas citoplasmáticas, em especial a mitocôndria e ruptura da membrana plasmática.

Schweichel e Merker (1973), baseando-se em estudos morfológicos durante o desenvolvimento de embriões de vertebrados, definiram três tipos de morte celular fisiológica: heterofagia, autofagia e morte não lisossomal. A heterofagia, conhecida hoje por apoptose, é caracterizada pela condensação do núcleo e do citoplasma seguida pela fragmentação do núcleo e fagocitose desta por células vizinhas. A morte por autofagia tem como característica a formação de vacúolos contendo lisossomos que degradam o conteúdo celular 
(LOCKSHIN e ZAKERI, 2002). A morte não lisossomal é caracterizada pelo inchaço de organelas seguido pela sua degeneração sem a atividade de lisossomos e rompimento da membrana plasmática.

\subsubsection{Morte celular programada}

A apoptose, conhecida também como morte celular programada (Programmed cell death - PCD), é um processo fisiológico importante na manutenção da homeostasia. O objetivo principal é a retirada de células defeituosas, que tenham alcançado o limite do seu ciclo de vida, por exemplo, sendo removidas "silenciosamente" e sem desencadear resposta inflamatória, como na remoção de linfócitos potencialmente auto-reativos. O processo apoptótico é um programa de suicídio celular presente na maioria das células e pode ser iniciado por uma variedade de sinais extrínsecos e intrínsecos (FADEEL e ORRENIUS, 2005). O termo apoptose foi introduzido pela primeira vez por Kerr et al., em 1972, por significar queda de folhas, uma analogia a uma parte do ciclo de vida das árvores. O processo é caracterizado pela alteração de aspectos morfológicos e bioquímicos como a ativação de proteínas conhecidas como caspases que orquestram o desmantelamento da célula, tendo como característica a condensação do núcleo e do citoplasma, seguido por fragmentação do núcleo (SHI, 2004).

A PCD é um processo altamente regulado. A desregulação desta pode desencadear distúrbios patológicos. A ativação excessiva, por exemplo, pode levar a degenerações neuronais que são observadas em pacientes com síndrome de Alzheimer e na doença de Parkinson (ECKERT et al., 2003; DLAMINI;MBITA;ZUNGU, 2004). A inibição da PCD leva ao surgimento do câncer, por exemplo, pois, as células cancerígenas não são retiradas e, portanto, proliferam-se formando o tecido neoplásico. Durante a senescência, a desregulação da PCD torna-se mais pronunciada, o que pode explicar a prevalência maior deste tipo de distúrbios em pessoas idosas (JOAQUIN e GOLLAPUDI, 2001). A PCD possui papel importante também na fisiopatologia da sepse. Pacientes sépticos exibem grau excessivo de apoptose dos linfócitos circulantes, principalmente das células T CD4 e CD8, B e NK. O grau de 
apoptose de células T CD3 correlacionado-se com o estado clínico destes pacientes (HOTCHKISS et al., 2005).

Existem vias alternativas de disparo da PCD, permitindo que esta seja dividida em duas subclasses: apoptose clássica e apoptose independente de caspases (JAATTELA e TSCHOPP, 2003).

\subsubsection{Apoptose clássica}

A apoptose clássica, conhecida também como apoptose dependente de caspase, era a única via de PCD conhecida. No entanto, em estudos mais elaborados e específicos sobre o tema, questões importantes foram levantadas. A ativação da via das caspases não necessariamente induz apoptose, bem como a inibição desta não confere proteção para a célula, ao ser exposta ao fator de necrose tumoral (TNF), por exemplo (WILSON e BROWNING, 2002; DIESSENBACHER et al., 2008).

As alterações morfológicas que uma célula sofre durante o processo apoptótico clássico foram descritas por Wyllie et al., em 1980. A célula em apoptose apresenta agregação de cromatina em grandes corpos granulares que se ligam à carioteca, que se apresentam anormalmente convolutas. $O$ nucléolo torna-se evidente e aumentado com grânulos pronunciados e dispersos. Concomitantemente, há condensação do citoplasma com o desaparecimento dos microvilos e surgimento de protuberâncias na superfície celular, os chamados "blebs" (Wyllie et al., 1980). Este processso é conhecido também por zeiose (PERL;CHUNG;AYALA, 2005). A condensação e o encolhimento do citoplasma deve-se à ativação de canais de $\mathrm{K}^{+}$e/ou $\mathrm{Cl}^{-}$e o extravazamento de osmólitos como cloreto de potássio ( $\mathrm{KCl}$ ) e água (LANG et al., 2005). Há o surgimento de vacúolos citoplasmáticos translúcidos, enquanto que no núcleo ocorre a clivagem do DNA por uma série de endonucleases que originam pedaços deste com tamanhos que variam entre 18 a 200 pares de bases (pb) (ISRAELS e ISRAELS, 1999). Esta é uma fase irreversível do processo apoptótico. Por fim, há o destacamento das "blebs" que formaram os corpos apoptóticos a serem fagocitados. 
Durante o processo apoptótico, há perda de assimetria dos fosfolipídeos da membrana plasmática, o que leva à externalização da fosfatidilserina (MARTIN et al., 1996). O reconhecimento das células apoptóticas a serem fagocitadas deve-se principalmente à apresentação da fosfatidilserina na superfície, que é reconhecida pelos receptores de membrana das células fagocíticas (FADOK et al., 2000; HENSON;BRATTON;FADOK, 2001). A célula em processo apoptótico também induz extravasamento de constituintes celulares, entre eles a lisofosfatidilcolina, um potente agente quimiotático lipídico para monócitos e macrófagos (FADOK, 2003).

A PCD não é limitada apenas a células nucleadas, podendo afetar similarmente os eritrócitos. Recentemente o termo eriptose foi utilizado para descrever a morte de eritrócitos, caracterizada pelo encolhimento do conteúdo celular e exposição de fosfatidilserina na superfície (BARVITENKO;ADRAGNA;WEBER, 2005; BOSMAN;WILLEKENS;WERRE, 2005; RICE e ALFREY, 2005). O processo apoptótico pode ser divido em três fases independentes: indução, decisão e execução.

\subsubsection{Indução}

Existem dois caminhos que levam à indução da apoptose: o extrínseco e o intrínseco (RATHMELL e THOMPSON, 2002).

\subsection{Via extrínseca}

$\mathrm{Na}$ via extrínseca, os indutores desencadeiam o processo apoptótico através de receptores de morte, pertencentes à superfamília dos receptores do fator de necrose tumoral (TNF). Em linfócitos, os membros mais importantes da superfamília de receptores de TNF envolvidos na sinalização intracelular são: receptores de TNF dos tipos 1 e 2 (TNFR1 e 2), conhecidos também como CD120a e CD120b, respectivamente, e receptor Fas, conhecido também por CD95 e Apo-1 (AGGARWAL, 2003). A sinalização via receptores de morte no sistema imune contribui, por exemplo, na regulação da resposta imune adaptativa, principalmente na ativação induzida de morte celular (AICD) nas células T. Portanto, a desregulação da sinalização dos receptores de morte 
leva a exacerbação ou inibição da apoptose, provocando alterações na função imunitária que pode impactar na tumorigênese e outras condições patológicas (FAS et al., 2006). Em resposta aos ligantes, TNFR1 e 2 e Fas recrutam proteínas que ligam-se aos seus domínios citoplasmáticos. Estas proteínas efetoras, que se diferenciam em estrutura e função, determinam a propagação do sinal intracelular que determina a sobrevivência ou apoptose. Os efetores podem ser enzimas como quinases, fosfatases e proteases (MAK e YEH, 2002).

Conforme o tipo de proteína efetora recrutada, os receptores da superfamília de TNF podem ser divididos em duas classes. Fazem parte da classe 1, TNFR1 e Fas, que possuem em sua região citoplasmática um domínio de morte - Death Domain (DD). Este domínio capacita os receptores a realizarem interações proteína-proteína. As proteínas recrutadas também possuem um DD. Por exemplo, TNFR1 contém DD que se liga à TRADD (TNF receptor associated $D D$ protein) e Fas contém um DD que se liga à FADD (Fas associated $D D$ protein). Essas proteínas (TRADD e FADD) regulam a apoptose, pois recrutam e ativam a caspase 8 (TIBBETTS;ZHENG;LENARDO, 2003). A ligação da FADD ao receptor Fas permite o recrutamento do complexo DISC (Death Inducing Signalling Complex) que contém proteínas adaptadoras que se ligam à pró-caspase 8 ativando-a para caspase 8 , conhecida também como FLICE (FADD-Like Interleukin 1 beta-Converting Enzyme), que subseqüentemente cliva-se para a ativação da caspase 3 , sendo esta a caspase efetora do processo apoptótico. A caspase 3 leva à degradação de proteínas celulares necessárias à manutenção da integridade e sobrevivência da célula como proteínas do citoesqueleto e da carioteca (SALVESEN e DUCKETT, 2002). A FADD regula negativamente as interações entre a interleucina 2 (IL-2) e seu receptor (IL-2R). Em linfócitos T, a deficiência desta interação reduz a capacidade proliferativa (MACK e HACKER, 2002).

A classe 2 dos receptores de morte (TNFR2) não contém DD. Esses receptores possuem uma seqüência de aminoácidos que se liga a adaptadores intracelulares denominados TRAF (TNF receptor associated factors) (LOCKSLEY;KILLEEN;LENARDO, 2001). As proteínas TRAFs são importantes 
para a sobrevivência celular porque recrutam proteínas inibidoras de apoptose e ativam o NF-kB (Nuclear Factor- kB), evitando a morte celular (WAJANT e SCHEURICH, 2004).

O NF-kB é um fator de transcrição que promove a expressão de mais de 200 genes, que atuam em diversos processos celulares tais como: sobrevivência, proliferação, respostas imune e inflamatória (BRADLEY e POBER, 2001). A desregulação do NF-KB é o fator essencial no surgimento de algumas desordens genéticas humanas como câncer, diabetes do tipo 1 , distrofia muscular como a de Duchenne e artrites reumatóides (KUMAR et al., 2004). Atualmente, cinco membros da família NF-kB são conhecidos: o p50, p52, p65 (conhecido também por RelA), c-Rel e RelB (Li et al., 2002). Esses formam entre si vários homo e heterodímeros, sendo que a grande parte ativa é formada pelos heterodímeros p50/RelA e p52/RelA (Pahl, 1999). As diversas combinações entre os membros da família NF-kB formam vários produtos que complexam em regiões diferentes do DNA, o que leva à transcrição de diversos genes (LI e VERMA, 2002). Ratos que possuem deficiência da RelA (p65), a principal sub-unidade do NF-kB, morrem durante a embriogênese, devido a apoptose excessiva que degrada o tecido hepático (SENFTLEBEN et al., 2001). O NF-KB está no citoplasma complexado com o seu inibidor I-KB. Este deve ser removido via fosforilação em um resíduo de serina, seguido por ubiquitinação e degradação proteassomal, que o NF-kB ser ativado (SENFTLEBEN e KARIN, 2002). A fosforilação de I-KB é mediada pela I-KB quinase (IKK), que é um complexo formado pelas proteínas IKKa, IKK $\beta$ e IKKץ, sendo esta última, conhecida também por NEMO (NF-kB Essential Modulator) (CLAUDIO et al., 2002).

Dentre os genes regulados pelo NF-KB estão os das proteínas: TRAF, IAP (Inhibitor of Apoptosis Protein), Fas ligante, Fas, caspase 11, Bcl-2 e Bcl-XL. O NF-kB, além de regular a atividade de proteínas anti-apoptóticas, controla a expressão de genes pró-apoptóticos (KARIN e LIN, 2002). O efeito próapoptótico pode ser mediado pela expressão elevada dos oncogenes p53 e cMYC que inibem a ativação do NF-kB (KLEFSTROM et al., 1997; YOU et al., 2002). Além destas, o NF-kB induz a expressão da FLIP (FLICE Inhibitor 
Protein), uma proteína inibidora da caspase 8. A desregulação desta proteína constitui um dos mecanismos de tumorigênese, como ocorre na doença de Hodgkin (THOMAS et al., 2002).

Legler et al (2003) demonstraram que, após a ligação do TNF, o TNRF1 transloca-se para um microdomínio de membrana, lipid raft rico em colesterol e esfingolípides, e associa-se com as proteínas TRADD, TRAFF e RIP (Receptor-Interacting Protein) formando um complexo. TNRF1 e RIP são então ubiquitinados e degradados. A alteração da organização do microdomínio, observada em células humanas de fibrossarcoma, não apenas inibe o processo de ubiquitinação, mas também altera a sinalização do TNF que deixa de ativar o NF-kB e permite a indução do processo apoptótico.

\subsection{Via intrínseca}

Pela via intrínseca, a apoptose pode ser induzida pela privação de fatores de crescimento e de diferenciação, defeitos na sinalização de receptores ou exposição a drogas e agentes que danificam o DNA, como a radiação ultravioleta (UV). Tais estímulos levam à translocação de proteínas pró-apoptóticas como a Bax para a mitocôndria. Esta proteína altera a integridade da membrana desta organela liberando seu conteúdo para o citoplasma (SALVESEN e DUCKETT, 2002).

A mitocôndria é uma organela essencial para a sobrevivência da célula pelo sua função na produção de ATP e como reguladora da programação da morte celular. Um dos principais fatores que medeiam a injúria mitocondrial é a abertura do poro de transição de permeabilidade (PTP). O PTP é constituído por um complexo de multi-proteínas que formam poros não seletivos na membrana mitocondrial interna. A abertura do PTP leva imediatamente à despolarização do potencial de membrana mitocondrial $(\Delta \psi \mathrm{m})$ e transforma esta organela de produtor de ATP em consumidor, revertendo a ATP sintase em uma tentativa inútil de manter a $\triangle \Psi m$ (NEWMEYER e FERGUSON-MILLER, 2003). A membrana mitocondrial apresenta potencial transmembrânico determinado pela disposição de íons entre o espaço intramembranoso e a matriz sendo esta última carregada negativamente. A ruptura do potencial 
transmembrânico é indicativo da formação do PTP (KROEMER;DALLAPORTA;RESCHE-RIGON, 1998; MINAMIKAWA et al., 1999). Esta ruptura pode ser detectada determinando a permeabilização da membrana mitocondrial interna, utilizando-se fluoróforos como a rodamina 123 (HENRY-MOWATT et al., 2004; FENNELL et al., 2005). Acredita-se que este poro cause perda da seletividade de íons da membrana mitocondrial (GREEN e AMARANTE-MENDES, 1998; ISRAELS e ISRAELS, 1999; SUSIN et al., 1999).

A abertura do PTP em longo prazo pode levar à entrada excessiva de água na matriz mitocondrial e o inchaço desta. Este desequilíbrio osmótico gerado leva à ruptura da membrana e o extravazamento de proteínas próapoptóticas. Dentre as proteínas que extravazam da mitocôndria, o primeiro a ser identificado foi o citocromo c, um componente da cadeia de transporte de elétrons. Junto com o citocromo c, há extravazamento das proteínas AIF (Apoptosis-Inducing Factor), Smac (Second Mitochondria-Derived Activator of Caspase), conhecida também como DIABLO (Direct Inhibitor of Apoptosis Protein Binding Protein with Low Isoeletric Point), Omi (também chamado de HtrA2) e endonuclease G (endo G) (PATTERSON et al., 2000; PLAS;RATHMELL;THOMPSON, 2002; ZHOU et al., 2005). O AIF e a endo G deslocam-se para o núcleo onde promovem condensação da cromatina e fragmentação de DNA. O citocromo c juntamente com ATP (trifosfato de adenosina) ativam a proteína citoplasmática Apaf-1 (Apoptosis Protease Activating Factor-1). O complexo formado pelo citocromo c, ATP e Apaf-1, juntamente com dímeros de pró-caspase 9, formam o apoptossomo. No interior deste, há ativação da caspase 9 que inicia a ativação de outras caspases, como as pró-caspases 3 e 7, iniciando uma cascata proteolítica (Adrain et al., 2001). A proteína Smac/DIABLO é clivada pela Omi/HtrA2, que é uma serina protease, expondo um domínio IBM/RHG (Inhibitor of Apoptosis Protein Binding Domain/ Reaper, Hid and Grim) amino terminal que regula a atividade das proteínas inibidoras de apoptose (IAPs- Inhibitors of Apoptosis Protein), neutralizando sua atividade anti-apoptótica (HENGARTNER, 2000; PLAS;RATHMELL;THOMPSON, 2002). 
As IAPs mais conhecidas são as c-IAP1, c-IAP2 e a XIAP (conhecida também como hILP-1 e MIHA), sendo esta última a melhor caracterizada (SUN et al., 1999). Estas proteínas inibem diretamente certas caspases como a 3, 7 e 9. O mecanismo pela qual a XIAP liga-se a cada tipo de caspase é diferente. Para a caspase 9, a XIAP possui um domínio BIR3 que tem um resíduo de zinco e que permite sua ligação ao terminal carboxila de uma subunidade da caspase. Esta subunidade é formada a partir da clivagem proteolítca em uma região conservada da caspase que apresenta um resíduo de aspartato, reconhecido pelo domínio BIR3 da XIAP (HUANG et al., 2003). A interação XIAP-caspase 9 é um potencial alvo terapêutico para apoptose de células neurais após convulsões e isquemias cerebrais (SHIBATA et al., 2002; SIEGELIN et al., 2005), doenças auto-imunes e câncer como o de próstata (HOLCIK;GIBSON;KORNELUK, 2001; HOLCIK e KORNELUK, 2001; DEVI, 2004). Para as caspases 3 e 7, a XIAP possui um domínio BIR2 que liga-se com alta afinidade a uma porção amino terminal, resultando em impedimento estérico para as caspases frente aos seus substratos. As atividades das IAPs são controladas por estímulos apoptóticos e pelo NF-KB (SALVESEN e DUCKETT, 2002). As IAPs podem ser inibidas pelo AMPc (adenosina monofosfato cíclico). Em estudo realizado com células de câncer de colo retal, observou-se grande aumento na atividade da COX-2 (enzima ciclooxigenase-2) e na formação de prostaglandinas (PG) do tipo E2. A PGE2 estimula os receptores EP2 e EP4, que aumentam a produção de AMPc (NISHIHARA et al., 2003), inibindo a ação das IAPs.

A via intrínseca pode também ser ativada pela via extrínseca quando a caspase 8 ativada cliva e ativa a proteína pró-apoptótica Bid, pertencente à família Bcl-2, em resposta à sinalização dos receptores de morte (ZHA et al., 2000). A Bid ativada transloca-se para a mitocôndria e auxilia na liberação do citocromo $\mathrm{c}$ atuando junto com a Bax. Tal mecanismo amplifica a sinalização para a morte celular (YIN et al., 1999). 


\subsubsection{Decisão}

A fase de decisão da apoptose é altamente regulada pelos membros pré e anti-apoptóticos da família de proteínas Bcl-2. Estas são integrantes de uma ampla variedade de cascatas de sinalização e, através de interações proteínaproteína, determinam se o balanço dos sinais recebidos irá levar a célula à morte (KAUFMANN e HENGARTNER, 2001).

Os membros da família Bcl-2 podem ser divididos em três subfamílias: (1) família Bcl-2 que inclui as proteínas anti-apoptóticas: $\mathrm{Bcl}-2, \mathrm{Bcl}-\mathrm{xL}, \mathrm{Bcl}-\mathrm{W}, \mathrm{A} 1 /$ Bfl-1, Boo/Diva, Nr-13 e Mcl-1, (2) família Bax que inclui as proteínas próapoptóticas: Bax, Bak e Boxk/Mtd e (3) família BH3-only que inclui as proteínas pró-apoptóticas: Bad, Bim/Bod, Bid, Bik/Nbk, Bnip3, Blk, Bmf, Hrk, Nix, Puma e Noxa (OPFERMAN e KORSMEYER, 2003).

As proteínas anti-apoptóticas, sendo a $\mathrm{Bcl}-2$ e a $\mathrm{Bcl}-\mathrm{XL}$ as mais caracterizadas, possuem a habilidade de controlar a integridade mitocondrial impedindo a oligomerização das proteínas pró-apoptóticas Bax e Bak, responsáveis pela formação de poros que permitem o extravazamento do conteúdo mitocondrial como o citocromo c (BOUILLET e STRASSER, 2002). Bcl-2 e Bcl-x são transportadas pela proteína FKBP38 que promove também a inserção destas na membrana mitocondrial, auxiliando, portanto, na sobrevivência da célula. Em estudos recentes, verificou-se que a ausência ou mutação do gene da FKBP38 altera a distribuição de Bcl-2 e Bcl-x, permitindo que a célula seja mais suscetível ao processo apoptótico (SHIRANE e NAKAYAMA, 2004). O FKBP38 é considerado inibidor constitutivo da serina/ treonina fosfatase ativada pela calcineurina. A serina/treonina fosfatase desfosforila a proteína Bad e também ativa a translocação de NF-AT (normal factor-AT) para o núcleo promovendo a transcrição da proteína Fas-Ligante (Fas-L) (SHIRANE e NAKAYAMA, 2003). Na presença de sinais promovidos por citocinas que ativam quinases como a proteína quinase $A(P K A)$ e a proteína quinase B (PKB ou Akt), ocorre fosforilação dos resíduos de serina/ treonina das proteínas Bad e FKHR (Fork Head Transcription Factor), que é um fator de transcrição de proteínas pró-apoptóticas. Estas são seqüestradas pela proteína 14-3-3, permanecendo no citossol da célula (MACKINTOSH, 2004). 
As proteínas da família 14-3-3, presentes nos eucariotos, regulam um grande número de vias de sinalização ligando-se a proteínas que possuem um resíduo específico de serina e/ou treonina fosforilados (FERL, 2004). Atualmente, são conhecidas mais de 100 proteínas que têm atividade regulada pela 14-3-3, através de diferentes mecanismos que incluem sequestro intra e intercompartimental, ativação/inibição da atividade enzimática e promoção/ inibição de interações protéicas. Entre as proteínas que interagem com a 14-3-3 podem ser destacadas a proteína quinase C (PKC), proteína G, Bad e IRS-1 (Insulin receptor substrate 1) (HERMEKING, 2003). A família das proteínas 14-3-3 em humanos compreende 7 isoformas: $\alpha, \beta, \gamma, \varepsilon, \sigma, \theta, \zeta$. O mecanismo de ação da 14-3-3 depende da formação de um dímero para que se crie um sítio de ligação para as proteínas fosfoforiladas, sendo este, um fator limitante para o funcionamento desta proteína (POZUELO RUBIO et al., 2004). Podem ser formados homo ou heterodímeros que se ligam a um ou dois ligantes simultaneamente. A regulação da 14-3-3 é feita através da fosforilação de um resíduo de serina na posição 58 (Ser58) que inibe a formação do dímero (YAFFE, 2004). Em células tumorais, por exemplo, este mecanismo leva a perda da resposta a sinais apoptóticos. Este processo pode ser devido a alteraçôes genéticas na maquinaria apoptótica ou em vias de sinalização, como a exacerbação da atividade da Akt (SAITO et al., 2004) e na perda da atividade do gene PTEN, que é um supressor tumoral, havendo então ativação da fosforilação da Bad na Ser136. A Bad possui uma alta afinidade pelas proteínas $\mathrm{Bcl}-2$ e Bcl-XL. Sua conformação é alterada quando ligada à 14-3-3, diminuindo esta afinidade (DATTA et al., 2000).

A Bad possui 3 sítios de fosforilação: a Ser112, Ser136 e Ser155 que são fosforilados por Akt, proteína quinase A (PKA), MAPK e ERK (TAN et al., 2000; HIRAI e WANG, 2001). Em estudo com células cancerígenas de pulmão, foi observado que a nicotina também pode induzir fosforilação destes resíduos de serina na Bad. É interessante o fato de que a inibição de receptores $\beta$ adrenérgicos destas células por propanolol inibe a ativação das proteínas relacionadas à fosforilação de Bad (JIN et al., 2004). A desfosforilação da Bad pode ocorrer através da calcineurina e pela proteína fosfatase 2A (PP2A) (WANG;PATHAN et al., 1999; CHIANG et al., 2001). 
Sob a perda dos sinais extrínsecos, Bad e FKHR são desfosforiladas e liberadas da proteína 14-3-3 (CHIANG et al., 2003). FKHR transloca-se para o núcleo e inicia a transcrição gênica de Bim, que, assim como a Bax, translocase para a mitocôndria. Bim liga-se à $\mathrm{Bcl}-2$ e $\mathrm{Bcl}-\mathrm{x}$ inibindo suas funções (RATHMELL e THOMPSON, 2002).

A apoptose pode também ser iniciada através da proteína Nur 77 (conhecida também como TR3), membro da superfamília de receptores nucleares orfãos de esteróide/tiróide/retinóide (ZHANG, 2002). A família das proteínas Nur77 compreende a própria Nur77, que está presente em todos os tecidos, a Nurr1, presente no timo, osteoblastos, fígado e glândula pituitária, e a Nor1, presente no timo, rins, coração, músculo esquelético e glândulas adrenais (BANDOH et al., 1997; MARUYAMA et al., 1997). Estas proteínas estão ligadas ao DNA como monômeros, homodímeros ou heterodímeros com o receptor retinóide X (WINOTO e LITTMAN, 2002). A Nur77 medeia principalmente a apoptose em timócitos imaturos, hibridomas de linfócitos $\mathrm{T}$ e tumores, sendo reportada a sua atuação em células cancerígenas de pulmão, próstata, ovário, cólon e estômago (SUZUKI et al., 2003). Um dos mecanismos de ação da Nur77 é a sua translocação do núcleo para a mitocôndria induzindo a liberação do citocromo c (CASTRO-OBREGON et al., 2004). A liberação do citocromo c está relacionada à ligação da Nur77 com a Bcl-2, alterando a conformação de sua estrutura o que a leva a apresentar seu domínio BH3, tornando-se um potente agonista da Bad (LIN et al., 2004).

Danos ao DNA como a quebra da dupla fita provocada por radiações, fármacos e agentes tóxicos, podem levar à apoptose caso não ocorra o reparo destes. O sinal para ativação do processo apoptótico é dado pela translocação de uma histona, a H1.2, que induz alteração conformacional e oligomerização da proteína Bak (YAN e SHI, 2003).

\subsubsection{Execução}

Nesta fase há ativação das caspases, enzimas que coordenam o processo apoptótico. As caspases (cisteína proteases) são constitutivamente expressas na forma de zimogênios (precursores inativos) presentes no 
citoplasma. As caspases ativam outras pró-caspases em uma cascata sequencial, mas podem também se autoativarem (PERFETTINI;KROEMER;KROEMER, 2004). Conforme sua função na célula e no processo apoptótico, as caspases são classificadas em 2 grupos principais: as caspases iniciadoras (caspases 2, 8, 9 e 10) cuja função é basicamente atuar sobre outras caspases e as efetoras que realizam o processo apoptótico (caspases 3, 6 e 7). A proteólise induzida pelas caspases efetoras é restrita e limitada. As proteínas são clivadas somente após apresentação de um resíduo específico de ácido aspártico produzindo uma desmontagem da proteína e não uma proteólise generalizada (MAK e YEH, 2002). A ativação das caspases resulta em: clivagem do citoesqueleto e da membrana nuclear e da liberação da DNA nuclease-CAD (Caspase Activated Deoxyribonuclease), permitindo a fragmentação nuclear (THORNBERRY e LAZEBNIK, 1998; ISRAELS e ISRAELS, 1999).

Os sinais de morte podem regular a expressão de genes como p-53, cmyc e genes da família $\mathrm{Bcl}-2$ que, por sua vez, regulam aspectos associados à sobrevivência e à morte celular (DBAIBO e HANNUN, 1998). A proteína p-53 é um fator de transcrição que normalmente está presente em baixas concentrações no citoplasma das células em eventos onde ocorrem danos ao DNA, sinais hiperproliferativos e hipóxia (SUTCLIFFE e BREHM, 2004). A p-53 é regulada por um fator de transcrição, o MDM2, que o regula negativamente diminuindo sua atividade e acelerando a sua degradação (BROOKS e GU, 2004). Em eventos no qual há degradação do DNA, ocorre aumento na transcrição do p-53 seguido de sua fosforilação, que a ativa e diminui sua ligação ao MDM2, aumentando a sua meia vida. Como resultado, há aumento de até cem vezes na atividade da p-53 (ATTARDI e DEPINHO, 2004). Dependendo da extensão do dano ao DNA, a p-53 pode induzir transcrição de genes que causam parada do ciclo celular para o reparo do DNA como a p21 ou genes que levam a célula à morte por apoptose como os genes de Bax, Bid, Puma e Noxa (OHTSUKA et al., 2004). Uma outra função da p-53 é regular a razão da expressão dos genes Bcl-2 e Bax cujos produtos são proteínas anti e pró apoptóticas, respectivamente. Um aumento da expressão dos genes homólogos de Bcl-2 inibe a apoptose. Todavia, a elevação da expressão do 
grupo de genes Bax promove apoptose. A p53 medeia a permeabilização mitocondrial através da interação física direta com as proteínas Bax e Bak. A interação entre p53 e Bak leva à oligomerização desta e a liberação do citocromo c. A formação do complexo p53-Bak coincide com a perda da interação de Bak com a proteína Mcl1, membro da família Bcl-2, que precede a ativação de caspases (LEU et al., 2004). Além disso, a p53 está envolvida também na distribuição rápida de receptores Fas do complexo de Golgi para a membrana plasmática (BENNETT et al., 1998).

A proteína c-myc é um fator de transcrição que regula a expressão de aproximadamente $15 \%$ de todos os genes através da sua ligação às seqüências E-boxes (Enhancer Box) e recrutando as histonas acetiltranferases (HATs), regulando assim a estrutura global da cromatina (GEARHART;PASHOS;PRASAD, 2007; COTTERMAN et al., 2008). Uma versão mutada do gene c-myc é encontrada em diversos tipos de câncer como no linfoma de Burkitt. A desregulação da expressão de c-myc não somente promove a proliferação como pode também induzir ou sensibilizar a célula à apoptose (PELENGARIS;KHAN;EVAN, 2002). O efeito de c-myc em potencializar a apoptose pode ocorrer por vários mecanismos. Dentre esses, cmyc induz a liberação de citocromo $c$ da mitocôndria (HOFFMAN e LIEBERMANN, 1998; SOUCIE et al., 2001). Em Trabalho conduzido por Soucek et al. (2008) foi verificado que a inibição temporária de c-myc induz a morte seletiva in vivo de células tumorais de ratos com câncer de pulmão, tornando esta técnica um potencial tratamento à doença.

\subsubsection{Apoptose independente de caspases}

A regulação da PCD envolve uma malha complexa de reações em cadeia, que ativa proteínas ativadoras, inibidores e até mesmo inibidores de inibidores, fenômeno comparado ao sistema complemento. A inibição das caspases inibe a formação do fenótipo característico da apoptose clássica definido pela condensação e encolhimento do material nuclear e formação dos corpos apoptóticos. Morfologicamente, as células que possuem a via das caspases interrompida possuem uma aparência "necrótica" ou "subapoptótica" (HOLLER 
et al., 2000). No entanto, tais processos podem ter algumas das características da apoptose clássica como a exposição de fosfatidilserina, perda do potencial de membrana mitocondrial e formação de corpos apoptóticos (LEIST e JAATTELA, 2001).

O fenótipo necrótico apresenta freqüentemente vacuolização citoplasmática e condensação de cromatina sem a presença dos corpos apoptóticos (VERCAMMEN et al., 1998). A exacerbação da morte por apoptose via TNF- $\alpha$ pode levar à necrose da célula. O TNF- $\alpha$ quando ligado ao TNFR1 sinaliza para a ativação da pró caspase 8 . No entanto, em estudos com inibição das caspases, observa-se que há aumento na produção e liberação de EROs da mitocôndria para o citossol, o que pode levar a degradação de estruturas e organelas. O mecanismo pelo qual a sinalização pelo TNFR1 induz a formação de EROs é desconhecido, mas, especula-se que caspases possuem a capacidade de digerir e inativar a fosfolipase $A_{2}$, responsável pela geração de ácido araquidônico e tendo como subproduto a formação de EROs. A formação de EROs, portanto, levaria à exacerbação da letalidade da célula (CAUWELS et al., 2003). Conclui-se que a ativação de caspases não necessariamente significa ativação da PCD, visto que estas podem inibir a formação de EROs. Acredita-se que as caspases podem atuar na destruição seletiva de organelas como no processo de desnucleação dos eritroblastos na formação dos eritrócitos (ZERMATI et al., 2001; KRAUSS et al., 2005), formação de plaquetas a partir dos megacariócitos (DE BOTTON et al., 2002) e na destruição seletiva de sinapses, requerida na plasticidade neuronal (PERFETTINI et al., 2002; VARMA et al., 2009).

\subsubsection{Morte por Autofagia}

A autofagia, conhecida também como morte celular do tipo II, ocorre devido à formação de vacúolos proteolíticos e a indução de morte necrótica ativada pelos receptores de morte (TOLKOVSKY et al., 2002). A autofagia pode ser estimulada pela privação de nutrientes nas células. Em modelos de leveduras, foi observado que a autofagia representa um mecanismo de sobrevivência que permite a sobrevida em períodos de privação alimentar 
(LEVINE e KLIONSKY, 2004). Durante a autofagia, uma porção do citoplasma é seqüestrada por uma estrutura conhecida como autofagossomo, que é formado por estruturas de membrana plasmática. Os autofagossomos fundemse com lisossomos que degradam o material sequestrado. Morfologicamente, a autofagia é caracterizada pelo aparecimento de vários vacúolos no citossol (LOCKSHIN e ZAKERI, 2002; GUIMARAES et al., 2003). No entanto, a autofagia não necessariamente induz a morte celular, visto que tal mecanismo pode ser utilizado como processo de reparo através da remoção de organelas danificadas/defeituosas ou reciclagem do material para obtenção de uma fonte de energia para células nutricionalmente deprimidas (JAATTELA e TSCHOPP, 2003).

$\mathrm{Na}$ apoptose clássica, a perda do potencial de membrana mitocondrial pode ativar a autofagia removendo a mitocondria, o que resulta em morte "atrasada" por inibição metabólica. Em células leucêmicas que têm inibição da expressão ou diminuição da atividade da Bcl-2, observa-se a ocorrência mais frequente de morte por autofagia do que pela apoptose clássica (SAEKI et al., 2000). Casos de doenças neurodegenerativas como Alzheimer e Parkinson, células em estado avançado de autofagia são freqüentemente observadas. Isto reforça a idéia de que a autofagia não está limitada apenas a uma resposta adaptativa à falta de nutrientes, mas também como mecanismo de suicídio celular (YUAN;LIPINSKI;DEGTEREV, 2003; GOZUACIK e KIMCHI, 2004).

Os lisossomos também atuam de maneira ativa na morte celular. Conhecidos como "bolsas de suicídio" devido à liberação de enzimas digestivas inespecíficas, levam a autólise celular que pode danificar células vizinhas devido ao conteúdo extravazado. Uma classe de proteases lisossomais, conhecida como catepsinas, participa da PCD, tanto na apoptose clássica e na independente de caspases, sendo induzida por diversos estímulos como os receptores de morte, a p53, sais biliares, pró-oxidantes e retinóides (GUICCIARDI et al., 2000; FOGHSGAARD et al., 2001). A ação das catepsinas resulta da clivagem da proteína Bid que induz a formação de poro na membrana mitocondrial junto à Bax (STOKA et al., 2001). Uma outra via independente de caspase utiliza a AIF, que originalmente extravaza do 
conteúdo mitocondrial junto com o citocromo c, translocando-se para o núcleo e iniciando a formação de fragmentos de cromatina contendo 50 pares de bases, através de mecanismos ainda desconhecidos (SUSIN et al., 1999). A AIF também participa da morte atrasada de neurônios induzida por injúrias agudas, como isquemias, e pode ser um importante executor da morte de células cancerígenas na ausência da atividade das caspases. A fragmentação do DNA pode ser induzida também por proteínas endo G e Omi/Htra2 conforme mencionado anteriormente (FOGHSGAARD et al., 2001).

\subsubsection{Morte por necrose}

A morte por necrose é induzida quando a célula é submetida a insultos drásticos como elevação da temperatura, pHs extremos, hipóxia, infecções por microorganismos e exposição a toxinas. A necrose é um processo considerado como passivo porque não requer a síntese de novas proteínas e não é regulada por mecanismo homeosático (WALKER et al., 1988; NICOTERA;LEIST;MANZO, 1999). Várias síndromes neurodegenerativas e doenças como Alzheimer, Hutington, Parkinson e epilepsia envolvem processo necrótico (PRICE;SISODIA;BORCHELT, 1998).

Do ponto de vista morfológico, nota-se, principalmente, perda de integridade da membrana plasmática, responsável pela manutenção da pressão osmótica no interior da célula, o que leva à alteração do diâmetro e do volume celular e de organelas, como retículo endoplasmático e mitocôndria, com a perda de suas funções. Como a célula possui uma pressão osmótica maior em relação ao meio externo, há a entrada de líquido, que causa o inchaço e rompimento desta. O colapso da membrana leva a liberação de proteases e lisossomos do conteúdo celular que induzem resposta inflamatória, sendo esta uma característica da morte por necrose (FERRI e KROEMER, 2001).

Os lisossomos contém mais de 80 tipos de enzimas hidrolíticas, incluindo as catepsinas, uma classe de protease não específica. O extravazamento destas enzimas para o citoplasma devido a injúrias à membrana lisossomal ou a ruptura desta são implicadas na morte celular por necrose após injúrias 
isquêmicas no cérebro e coração (ADAMEC et al., 2000). A resposta inflamatória causada pela necrose, entretanto, apresenta significância adaptativa atuando como resposta imunológica emergencial em condições patológicas como infecções e câncer. Por outro lado, distúrbio do balanço fino entre necrose e apoptose pode ser uma resposta para o desenvolvimento de patologias ligadas morte celular (PROSKURYAKOV;KONOPLYANNIKOV;GABAI, 2003). Em modelos celulares de diabetes, ilhotas de Langerhans isoladas morrem por apoptose e necrose quando expostas a citocinas como IL-1 $\beta$, TNF- $\alpha$ e IFN-Y (SALDEEN, 2000).

Em modelos de necrose celular induzida por depleção energética como a isquemia, foi observada uma série de eventos que podem caracterizar este tipo de morte. A isquemia leva à depleção energética da célula induzindo desequilíbrio iônico, através da diminuição da atividade da sódio/potássio ATPase, que resulta na perda do potássio e acúmulo de sódio e água. Há acúmulo de cálcio devido à falta de ATP, que é necessário para a manutenção da bomba de cálcio. Como o sequestro de cálcio intracelular é prejudicado, o acúmulo promove ativação de proteases, lipases e nucleases iniciando-se assim o processo de desmantelamento da célula (SZABO, 2005).

A reperfusão desta célula desencadeia a geração de uma série de oxidantes e radicais livres que culmina na depleção de antioxidantes e na disfunção mitocondrial, bem como na ruptura do DNA e ativação da poliadenosina ribose difosfato polimerase (PARP). A PARP é uma enzima nuclear que possui função de reparo do DNA. Durante a apotose, a PARP é normalmente inativada pela clivagem por uma caspase específica. Se este mecanismo de inativação não ocorre, a célula torna-se mais suscetiva à necrose quando exposta a radiação UV e lou TNF (HERCEG e WANG, 1999; KIM et al., 2000). No entanto, em condições patológicas como na injúria por reperfusão e choque circulatório, a ativação da PARP participa do processso inflamatório e da necrose celular. Estresse oxidativo e nitrosativo induz quebra do DNA em regiões que são reconhecidas pela PARP resultando em mudanças conformacionais que ativam domínios catalíticos de sua porção carbono terminal. A PARP ativada cliva o seu substrato nicotina adenina dinucleotídeo 
oxidada $\left(\mathrm{NAD}^{+}\right)$em ADP-ribose e nicotinamida (VIRAG;SALZMAN;SZABO, 1998). O gasto energético elevado deste processo culmina na disfunção mitocondrial, que pode induzir ao extravazamento de seu conteúdo. Um dos produtos liberados é o AIF, que potencializa o processo de quebra do DNA (HONG;DAWSON;DAWSON, 2004). A BNIP3 é uma proteína da família das $\mathrm{Bcl}-2$ que também é extravasada sendo forte indutora de necrose celular. $\mathrm{O}$ mecanismo de atuação desta ainda é incerto, mas supõe-se que seja ativada pelo óxido nítrico (YOOK et al., 2004; ZAMORA et al., 2005). Em estudo com células de câncer pancreático, observou-se que a expressão do gene da BNIP3 estava reduzida quando comparada com células normais. Este resultado foi correlacionado com a contribuição na resistência das células cancerígenas quanto ao tratamento quimioterápico e a piora do prognóstico (ERKAN et al., 2005).

Os lípides e seus produtos de peroxidação também podem induzir morte por necrose. A LDL (lipoproteína de baixa densidade) oxidada, por exemplo, tem efeito citotóxico dose e tempo dependente estando associado ao aumento do cálcio intracelular. Em estudos realizados com modelos de células que sintetizam grande quantidade de $\mathrm{Bcl}-2$, verificou-se que a morte pela $\mathrm{LDL}$ oxidada ocorre via necrose e em células com baixa síntese de Bcl-2 a morte deu-se por apoptose (MEILHAC et al., 1999; TASHIRO et al., 1999). Esteróis oxidados também induzem necrose em fibroblastos e apoptose em células do endotélio e de músculo liso (LIZARD et al., 1999). O acúmulo de ceramidas, que é um produto de hidrólise de esfingomielinas, pode induzir necrose em hepatócitos, próstata e glioma (ENGEDAL e SAATCIOGLU, 2001; MOCHIZUKI et al., 2002).

Recentemente, foi descoberta uma proteína, a HMGB-1 (High Mobility Group Box 1), que é liberada pelas células necróticas e possui atividade de citocina induzindo processo inflamatório (WANG;BLOOM et al., 1999; SCAFFIDI;MISTELI;BIANCHI, 2002). A HMGB-1 era conhecida por ser uma proteína nuclear e produzida por quase todos os tipos celulares. No núcleo, esta se liga ao DNA e altera a sua conformação propiciando sítios de ligação para fatores nucleares como o NF-kB e receptores de hormônios esteróides 
(BIANCHI, 2004). As funções nucleares da HMGB-1 são essenciais à sobrevida das células. Em estudo realizado com ratos nocautes para a HMGB-1, verificou-se que estes sobrevivem apenas por curto período após o nascimento. Fenotípicamente apresentaram tamanho pequeno, crescimento e distribuição desorganizada dos pêlos e ausência de gordura (CALOGERO et al., 1999). Como um mediador inflamatório, a HMGB-1 liga-se a receptores de membrana como os Toll-like receptors (TLR) 2 e 4, elicitando uma série de respostas celulares como febre, disfunção da barreira epitelial, quimiotaxia e liberação de citocinas pró-inflamatórias como TNF- $\alpha$ e IL-1 $\beta$ (WANG;YANG;TRACEY, 2004; YANG et al., 2005). A HMGB-1 não é liberada por células que morrem por apoptose. Esta é liberada somente de forma passiva pelas células necróticas ou ativamente pelos monócitos e macrófagos, potencializando o processo inflamatório (ERLANDSSON HARRIS e ANDERSSON, 2004).

\subsection{METABOLISMO E FUNÇÃO DE LINFÓCITOS T}

\subsubsection{Linfócitos T}

Os linfócitos são células importantes na resposta imunológica tanto humoral quanto celular e sua funcionalidade está relacionada não só com a capacidade de defesa do organismo contra infecções mas também com o desenvolvimento de doenças autoimune (ROITT, 1972).

Os linfócitos T originam-se a partir de precursores pluripotentes presentes na medula óssea ou fígado fetal que migram para o timo onde iniciará o processo de diferenciação e viabilidade de células T. Poucas células progenitoras de linfócitos $T$ migram por dia para o timo. No entanto, o microambiente proporcionado por este órgão permite a proliferação dessas células extensivamente enquanto iniciam o programa de transcrição para a diferenciação celular e o silenciamento de genes que podem levar ao diferenciação de outros tipos celulares (ANDERSON, 2006; HAYDAY e PENNINGTON, 2007). Em seguida há o rearranjo do gene do receptor de 
células T (TCR) o que permite a formação de complexos de TCR, responsável pela sobrevivência e função destas células. Estas células maturam-se e podem diferenciar-se em diferentes linhagens de células $T$ incluindo as células $T \gamma \delta$ e as $T \alpha \beta$. As células $T \alpha \beta$ podem ainda originar sub linhagens como as células $T$ CD4+, T CD8, Natural Killers (NK) e as T regulatórias (T reg), cada uma com funções diferentes no sistema imune uma vez que migram do timo para a periferia.

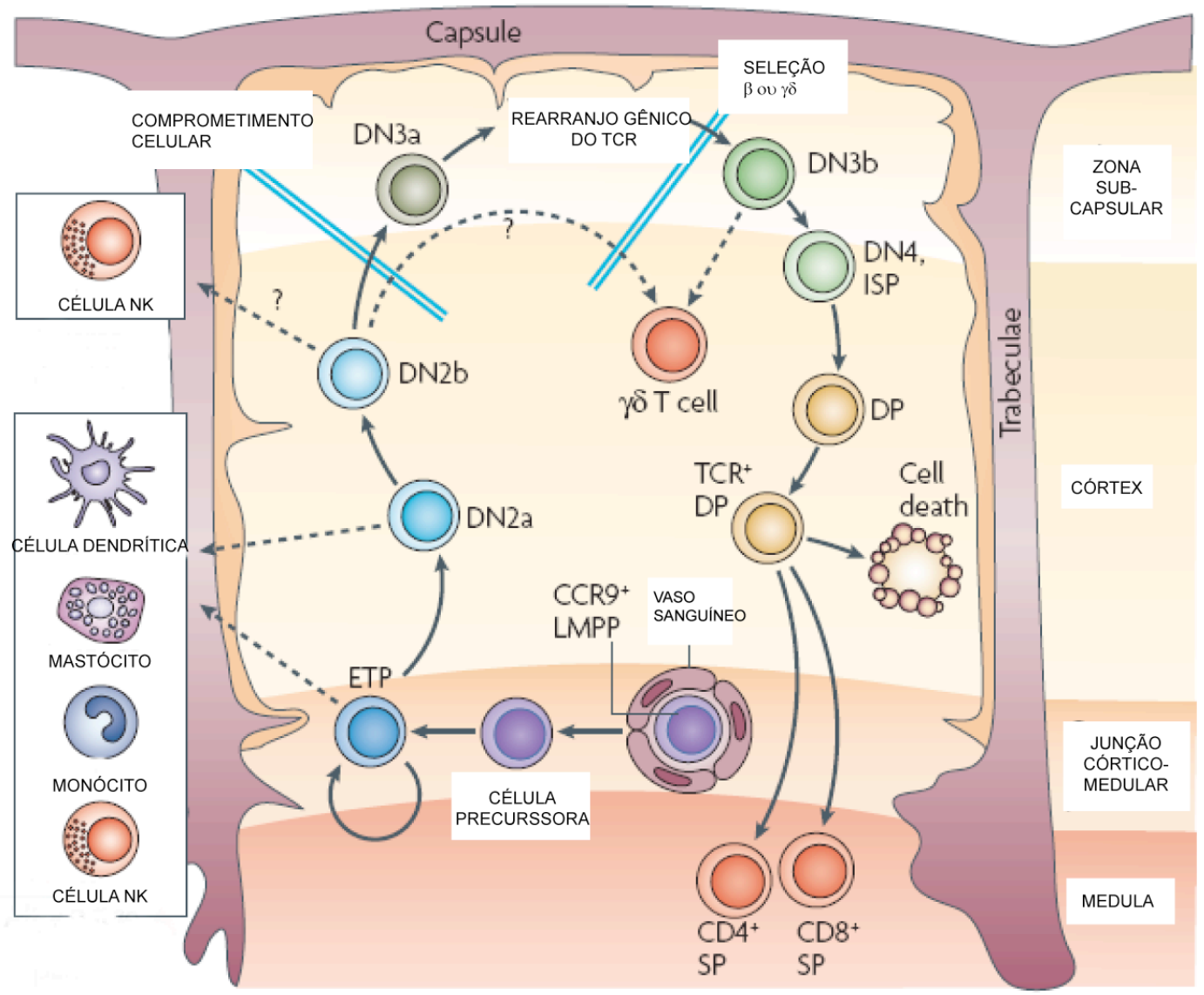

Figura 1- Estágios de desenvolvimento do linfócito $T$. Corte transversal de um lóbulo tímico mostrando a migração de precursores de célula $T$ durante $o$ desenvolvimento. Os precursores inicialmente entram no timo através dos vasos sangüíneos próximos da junção córtico medular. Subseqüentemente, os precursores de células $T$ (ETP) migram e diferenciam-se a estágios duplos negativos (DN) ou duplos positivos(DP) ou único positivos (SP) pelos diversos microambientes do timo. Estas células maturam-se e diferenciam-se dando origem a diferentes linhagens de células $\mathrm{T}$.

FONTE: Rothenberg, Moore e Yui (2008). 
O processo de comprometimento da linhagem de células-T consiste em uma progressão irreverssível de estágios distintos de desenvolvimento. Isto implica em mudanças regulatórias particulares que intervém no avanço da célula de um estágio para o próximo. O controle deste desenvolvimento é realizado especialmente pela via de sinalização Notch. Esta via de sinalização é altamente conservada e está presente na maioria dos organismos multicelulares (LAI, 2004). Regula o destino e desenvolvimento de células e também de células tronco. A via de sinalização Notch medeia a regulação de diversos arrays de decisões durante o desenvolvimento celular de sistemas como o neuronal, cardíaco e endócrino através de sinalização justácrina entre células adjacentes. Esse requerimento do contato direto permite o controle preciso da diferenciação celular (PUI et al., 1999; JOSHI et al., 2009). As proteínas Notch são receptores transmembrana compostos de domínios extracelular (NECD), transmebrânicos (TM) e intracelular (NICD). O processamento dos receptores Notch é feito pelo retículo endoplasmático e complexo de Golgi. Após estímulo, há a clivagem do precurssor Notch que resulta em um heterodímero glicosilado e estabilizado pelo $\mathrm{Ca}^{2+}$, composto pelo NECD ligado não-covalentemente ao TM-NICD que regulam a decisão do destino da célula durante o desenvolvimento (BRAY, 2006). A família Notch inclui quatro receptores: $\mathrm{NOTCH} 1, \mathrm{NOTCH} 2, \mathrm{NOTCH} 3$ e $\mathrm{NOTCH} 4$, cujos ligantes incluem as proteínas das famílias do tipo JAG (JAG1, JAG2) e do tipo Delta (DLL1, DLL3, e DLL4), todos secretados pelas células que enviam o sinal para as células alvo. Esses receptores apresentam um domínio extracelular contendo múltiplas repetições de fator de crescimento da epiderme (EGF) e uma região intracelular contendo o domínio RAM, repetições ancirina (uma proteína da membrana eritrocitária que se liga a espectrina proteína tetramérica do citoesqueleto) e um domínio PEST (proteína tirosina fosfatase) no terminal C (terminal carboxila) (DAS et al., 2004). A interação do ligante ao receptor Notch inicia a clivagem deste separando a porção NECD da porção TM-NICD pela enzima TACE (ADAM metalloprotease TNF- $\alpha$ converting enzyme). A porção NECD continua ligada ao ligante e este complexo é endocitado e degradado/reciclado. A porção TM-NICD é clivada pela Y-secretase e libera a NICD da TM que transloca-se para o núcleo e associa-se ao fator de 
transcrição CSL (complexo formado pelas unidades CBF1/Su(H)/Lag-1), resultando na ativação dos genes alvos Notch: Myc, p21 e membros da família HES (FIUZA e ARIAS, 2007).

As mutações do receptor Notch podem levar ao acúmulo de NICD, característica comum em casos de leucemia linfoblástica aguda e linfoma (Aster et al., 2008). A perda da função do receptor Notch e a mutação dos ligantes estão implicados em diversas desordens como a síndrome de Alagille (mutação do ligante JAG1 ou do receptor NOTCH2 implica na má formação de órgãos como o coração e fígado, ductos biliares e coluna espinhal) e arteriopatia cerebral autossômica dominante (ODA et al., 1997; SAMEJIMA et al., 2007).

A sinalização via receptores Notch e de interleucina-7 (IL-7) atua na manutenção da viabilidade celular e a promoção da diferenciação de timócitos a linfócitos T. A sinalização via Notch é importante para a expressão dos receptores de célula $T$ (TCR) e para o metabolismo de glicose via ativação de Akt (CIOFANI e ZUNIGA-PFLUCKER, 2005). A IL-7 é o fator de crescimento de células T imaturas mais importante induzindo a proliferação destas no timo .

\subsubsection{Metabolismo de linfóctios T}

O sistema imune é de fundamental importância, não apenas prevenindo ou limitando uma infecção mas também no processo de reparo e recuperação frente a uma injúria. $O$ disparo de uma resposta imune eficiente e efetiva envolve um aumento significativo nas atividades celulares quanto a proliferação (linfócitos), biossíntese e secreção (macrófagos). As mudanças necessárias na expressão de genes e proteínas para mediar estes processos requer demanda bioenergética elevada. A provisão de substratos metabólicos para gerar ATP e precurssores anabólicos para o crescimento celular é essencial para a função imune (CALDER, 1995; NEWSHOLME et al., 1996).

Os linfócitos $T$, quando saem do timo, alcançam a circulação periférica como células quiescentes. Estas células consomem glicose e outros nutrientes essenciais como a glutamina para manterem as suas funções basais ( et al., 1978; TOLLEFSBOL e COHEN, 1985). Mesmo neste estado, a taxa de 
utilização destes metabólitos é alta, cerca de 100 vezes maior que a necessidade biossintética para o estado (CURI et al., 1999). A utilização de glicose é dividida principalmente entre síntese de oligossacarídeos (reações de glicosilação), produção de lactato (via glicólise) e oxidação a $\mathrm{CO}_{2}$ (via glicólise e ciclo de Krebs e via das pentoses) (HUME et al., 1978). A manutenção da taxa metabólica basal das células $\mathrm{T}$ requer também sinais extracelulares incluindo citocinas e estimulação do TCR. Na ausência destes sinais, os linfócitos $T$ reduzem sua capacidade de captar glicose a valores inferiores àqueles necessários para manter a homeostase celular (RATHMELL et al., 2000; RATHMELL et al., 2001). Portanto, a manutenção do metabolismo basal de linfócitos $\mathrm{T}$ depende não só da disponibilidade de metabólitos energéticos mas também de sinais tróficos como citocinas. Em adição à glicose e glutamina, outros metabólitos como corpos cetônicos e ácidos graxos também podem ser utilizados por linfócitos (NEWSHOLME, 2001).

Quando estas células são estimuladas por antígenos como vírus ou bactérias, é observado aumento na utilização desses substratos. Nestas condições ocorre uma rápida proliferação celular e, para assegurar a eficiência no suprimento da demanda metabólica, as vias glicolítica e glutaminolítica estão sempre ativas mesmo em linfócitos no estado quiescente. Trata-se da regulação em ramo proposta por Crabtree e Newsholme (1985) e que explicaria o alto fluxo de metabólitos em células no estado quiescente, que apresentam potencialidade para proliferação rápida. Assim, essas vias, além de fornecerem consideráveis quantidades de ATP, gerariam intermediários importantes para a síntese de purinas, pirimidinas, DNA, RNA, NADPH, glicerolfosfato e acetilCoA.

A sinalização de insulina é o principal sistema controlador do metabolismo de glicose em diversos tipos celulares como as células musculares e adipócitos. A ligação da insulina ao seu receptor leva à ativação da fosfatidilinositol-3-quinase (PI3K) e o seu efetor Akt, que induz captação de glicose e sua utilização. As células $T$ não respondem à insulina, necessitando ligantes para o receptor co-estimulatório CD28, que similarmente ao hormônio, ativa a via PI3K/Akt (PARRY et al., 1997). 
a

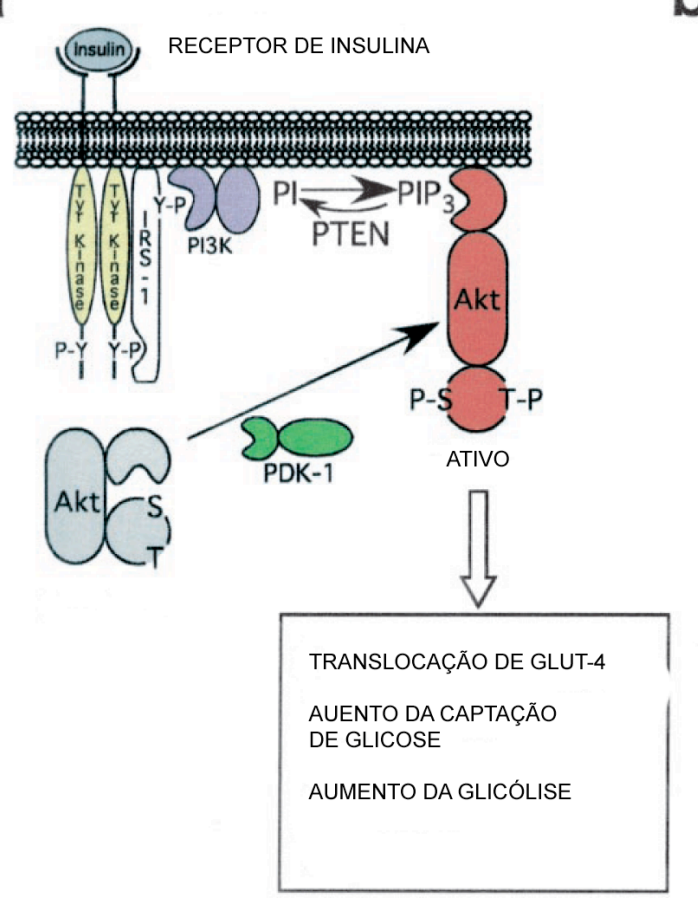

D

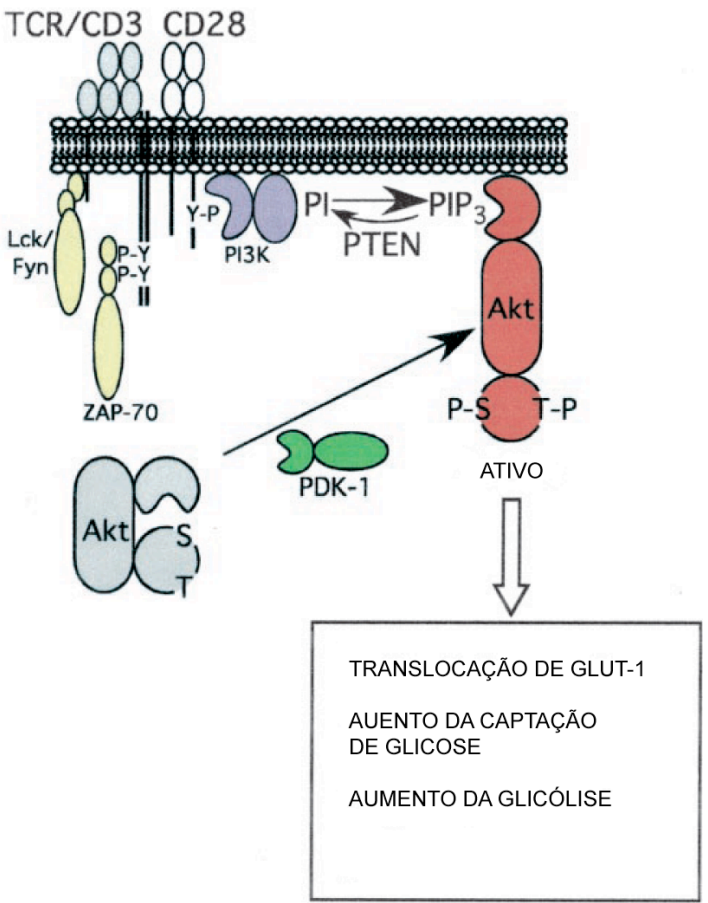

Figura 2 - Comparação do processo de captação de glicose nas células que respondem à insulina (a) e os linfócitos $T$ (b). (a). Ligação da insulina ao seu receptor dispara a atividade intrínseca de tirosina quinase levando ao recrutamento e fosforilação da proteína adaptadora IRS-1 seguidos pelo recrutamento e ativação de PI3K. PI3K gera PIP3 que recruta Akt para a membrana plasmática onde pode ser ativada pela quinase responsiva aPI3K, a PDK-1. A Akt ativa promove a redistribuição de GLUT-4 para a superfície celular e aumenta a captação de glicose e a metabolização desta em células que respondem à insulina. (b). Co-ligação do complexo TCR com CD28 em células T leva à fosforilação do CD28 e o recrutamento de PI3K. Como no exemplo anterior, a PI3K leva à ativação de Akt com os efeitos metabólicos da síntese de GLUT-1 e sua translocação à superfície e o aumento da captação de glicose e ativação da glicólise.

FONTE: Rathmell et al. (2000).

Além do metabolismo de glicose, a ativação de linfócitos T aumenta a biossíntese de macromoléculas. O regulador central deste processo é proteína a mTOR (mammalian Target Of Rapamycin). A inibição de mTOR por rapamicina leva à interrupção do ciclo celular e mimetiza os efeitos de um programa de restrição de aminoácidos (SCHMELZLE e HALL, 2000). A rapamicina é também um potente supressor de células $T$, indicando a importância da mTOR durante a sua ativação. A mTOR regula também a síntese de proteínas via fosforilação de múltiplos alvos incluindo a p70S6 quinase, um regulador da função ribossômica, e a 4E-BP1, um inibidor do processo de transcrição. A mTOR também direciona a expressão de uma 
variedade de transportadores de nutrientes na membrana plasmática como os transportadores de aminoácidos, receptores de lipoproteínas de baixa densidade e de transferrina em resposta à sinalização de Akt (EDINGER e THOMPSON, 2002). Portanto, o controle do transporte de glicose é coordenado com o importe de outros nutrientes requeridos para o crescimento celular via sinalização de Akt e mTOR.

Em adição à função de ativador da maquinaria metabólica, a Akt pode interagir com outros reguladores do metabolismo. A proteína quinase dependente de AMP (AMPK) é um importante sensor do conteúdo celular de ATP, sendo ativada quando a razão AMP/ATP é aumentada, com isso há a busca de processos alternativos de geração de energia como a oxidação de ácidos graxos na mitocôndria bem como supressão de processos que consomem muita energia como a síntese de proteínas, colesterol e ácidos graxos (RUTTER;DA SILVA XAVIER;LECLERC, 2003). Contudo, o crescimento de células $\mathrm{T}$ requer a síntese de uma rede de citoesqueleto e membranas e portanto, a ativação de AMPK rapidamente inibe o crescimento celular. A ativação de Akt leva à inibição da quinase de AMPK. A Akt pode, portanto, por meio dessa regulação permitir que uma célula $T$ ativada aumente a produção de ATP, sem a oxidação de ácidos graxos, requerido para a síntese de novas membranas e para o crescimento celular (KOVACIC et al., 2003).

Esta correlação estreita entre metabolismo e a função celular, constitui a base para o entendimento de mecanismos potenciais no controle da funcionalidade de linfócitos e, portanto, da função imune (DONG et al., 1992; NONNECKE;FRANKLIN;YOUNG, 1992; NEWSHOLME e DIMITRIADIS, 2007).

\subsection{OS ÁCIDOS GRAXOS}

Os ácidos graxos (AG) possuem diversas funções nas células atuando como substrato energético, componentes estruturais de membrana e moléculas de sinalização. No sistema imune, podem atuar diretamente na sua forma livre ou através da geração de metabólitos biologicamente ativos como os eicosanóides. Os AG podem também atuar em vias de sinalização indiretamente através da modulação da fluidez da membrana plasmática, na 
composição dos microdomínios de membrana (lipid rafts) e na produção de segundos mensageiros como o diacilglicerol. Alternativamente podem atuar diretamente via receptores de membrana como os TLRs ou através de receptores nucleares como o PPAR e o NF-KB. Em maior extensão os AG podem afetar sistemas biológicos através da geração de espécies reativas de oxigênio e de nitrogênio (ROS e RNS, respectivamente) e induzir morte celular (MARTINS DE LIMA et al., 2007).

\subsubsection{Classificação de ácidos graxos}

Os AG são ácidos carboxílicos com uma cadeia alifática de 4 a 28 carbonos e podem ser classificados como saturados, monoinsaturados ou poliinsaturados. Os AG monoinsaturados possuem uma única dupla ligação e os poliinsaturados (PUFA - polyunsaturated fatty acids) contêm duas ou mais duplas. Como qualquer ácido carboxílico, os $A G$ podem ser esterificados e formar compostos lipídicos como os triacilgliceróis, fosfolípides, ésteres de colesterol e ceramidas. Em mamíferos, os ácidos graxos podem ser sintetizados pela enzima ácido graxo sintetase (FAS - Fatty Acid Synthetase), em processo denominado síntese de novo de AG, caracterizado por uma série de reações de condensação e descarboxilação entre moléculas de acil-CoA e malonil-CoA. O produto final desta síntese é o ácido palmítico (PA), saturado de 16 carbonos (16:0) e que pode ser elongado dando origem aos ácidos esteárico (18:0), eicosanóico (20:0), behênico (22:0) e lignocérico (24:0) ( et al., 1975; CHIRALA et al., 2001). O ácido esteárico ainda pode ser convertido a ácido oleico $(18: 1, \omega-9)$ com uma insaturação introduzida pela enzima $\Delta^{9}$ dessaturase entre os carbonos da posição $\mathrm{C}_{9}$ e $\mathrm{C}_{10}$.

No entanto, os humanos não têm a capacidade de produzir os AG insaturados $\omega-3$ e os $\omega-6$, conhecidos como $A G$ essenciais e que são obtidos através da dieta, bem como todos os outros citados.

Dentre os AG $\omega-6$ destaca-se os ácido linoleico (18:2) e y -linolênico (18:3), que são precursores do ácido araquidônico (20:4) que participa da biossíntese dos eicosanóides. A essencialidade dos ácidos graxos $\omega-6$ é conhecida desde a década de 1930 quando George e Milfred Burr observaram 
que ratos com dieta deficiente de AG $\omega-6$ apresentavam descamação anormal da pele, inchaço da cauda que evolui para necrose, aparecimento de feridas, parada de crescimento do animal, entre outros sintomas que culminara na morte.

Dentre os $A G \omega-3$ destaca-se os ácidos $\alpha$-linolênico (18:3), eicosapentaenóico (EPA, 20:5) e o docosaexaenóico (DHA, 22:6) que também podem participar do processo de síntese de eicosanóides. Em estudos realizados com animais e crianças, verificou-se a essencialidade dos ácidos $\omega-3$ principalmente durante o desenvolvimento do sistema nervoso central (embriogênese e infância). A deficiência destes acarretava em alterações na capacidade de aprendizado, menor acuidade visual, diminuição na tolerância ao etanol e a anestésicos (AUESTAD e INNIS, 2000; GIBSON e MAKRIDES, 2000).

\subsubsection{Metabolismo e funções de ácidos graxos}

Os AG são acumulados em células adiposas na forma de triacilgliceróis. Além da função de estocagem, os adipócitos produzem citocinas como a leptina, resistina e adiponectina, que atuam como moléculas de comunicação entre o tecido adiposo e outros tecidos. A quebra desta comunicação causa acúmulo de $A G$, na forma de triacilgliceróis em músculos, fígado, coração e pâncreas (UNGER e ORCI, 2001). Em resposta a hormônios como o glucagon, há ativação da lipase sensível a hormônio que promove a quebra dos triacilgliceróis em ácidos graxos livre ( $A G L)$ que são liberados na circulação. Os AGL são complexados a moléculas de albumina circulantes o que aumenta a sua solubilidade e o seu transporte para tecidos como o fígado e músculos para serem oxidados (RICHIERI e KLEINFELD, 1995; ZECHNER et al., 2005). Os AG atravessam a membrana plasmática rapidamente por difusão simples ou mediada pela criação de um gradiente de concentração promovido por proteínas citoplasmáticas como as FABPs (Fatty Acid Binding Protein). No interior da célula, os AG são transportados à mitocondria pela proteína carnitilpalmitoil transferase I (CPT-I). Nesta organela ocorre o processo de $\beta$-oxidação no qual moléculas de acetli-CoA são geradas à partir da degradação do AG. O acetil-CoA é então introduzido ao ciclo de Krebs. Neste, ocorre a geração de 
$\mathrm{NADH}$ e $\mathrm{FADH}_{2}$ que subseqüentemente serão utilizadas na cadeia de transporte de elétrons para a produção de ATP.

No entanto, o aumento do aporte de $A G$ às células pode diminuir a captação de glicose como descrito por Randle et al. (1963). Esses autores observaram que o aumento na disponibilidade de AG diminui a utilização de glicose em músculos cardíaco e diafragma de ratos. Os autores concluíram que o excesso de AG eleva a produção de acetil-CoA e NADH, que inibem a enzima piruvato desidrogenase $(\mathrm{PDH})$, diminuindo a conversão de piruvato a acetil-CoA. O aumento do conteúdo de acetil-CoA proveniente de AG eleva também a produção de citrato, que juntamente com a razão ATP/ADP elevada inibe a enzima fosfofrutoquinase, resultando em redução da via glicolítica. Como conseqüência, há aumento do conteúdo de glicose-6-fosfato, o qual passa a inibir a enzima hexoquinase II, causando acúmulo de glicose intracelular e portanto, redução do seu transporte. Deste modo, a diminuição da captação e utilização de glicose resulta em resistência à insulina.

A fluidez da membrana plasmática é determinada principalmente pela composição lipídica. O aumento na incorporação de ácidos graxos saturados leva ao surgimento de estruturas rígidas. Em contraste, o aumento da incorporação de PUFA torna a membrana celular mais fluídica. O número de receptores e a afinidade destes pelos seus respectivos ligantes dependem da fluidez da membrana celular. Por exemplo, o aumento da rigidez da membrana celular reduz o número de receptores de insulina e a afinidade por este hormônio, o que leva à resistência insulínica (CALDER, 1997).

Os $A G$ atuam também na regulação e síntese de mediadores lipídicos como os eicosanóides. Estes participam da cascata de síntese das lipoxinas, leucotrienos e prostaglandinas, que modulam a atividade e extensão da resposta imune. Em adição aos eicosanóides outros mediadores lipídicos importantes como os endocanabinóides, lisofosfolípides, fator ativador plaquetário e as resolvinas também são sintetizados à partir dos AG (YAQOOB, 2004). 


\subsubsection{Modulação da função celular por ácidos graxos}

Embora os AG estejam ligados à albumina no sangue, uma concentração extremamente baixa encontra-se na sua forma livre prevenindo o efeito direto dos AGL em diversas funções celulares. A elevação da concentração de AGL pode, por exemplo, inibir a sua ativação, degranulação e funções citossólicas de linfócitos (RICHIERI e KLEINFELD, 1989; et al., 1993). A ativação do linfócito $T$ é primordial para a iniciação da resposta imune e a inibição desta função pelos AGL pode evocar um efeito imunossupressor relevante. Os AGL têm sua concentração plasmática aumentada em situações de jejum, exercício físico intenso e obesidade. Além disso, esta elevação está associada a patologias como o diabetes do tipo 2 (T2DM - Type 2 Diabetes Mellitus) (REAVEN et al., 1988), câncer ( et al., 1987), sepse e isquemias (HENDRICKSON et al., 1997).

No T2DM é observada uma alteração metabólica caracterizada pela glicemia e concentração de lípides circulantes elevada acompanhadas por uma diminuição na secreção de insulina estimulada pela glicose. A diminuição da secreção do hormônio é atribuída à exposição crônica das células $\beta$ pancreáticas a concentrações elevadas de glicose e AGL, que pode levar à uma redução da massa funcional de células $\beta$ (glicolipotoxicidade) (ZHOU e GRILL, 1994; YANEY e CORKEY, 2003).

Além da inibição das funções celulares, concentrações elevadas de AGL podem induzir morte celular. Em um estudo utilizando células de Leydig de ratos tratadas com os ácidos palmítico e esteárico, verificou-se a promoção de apoptose via formação de ceramida, induzindo ativação expressiva de Bax (LU et al., 2003).

A mitocôndria possui função de destaque na morte celular induzida por AG. Diferentes mecanismos têm sido descritos como (1) inibição e/ou desacoplamento da fosforilação oxidativa com subsequente queda na produção energética; (2) geração de espécies reativas de oxigênio, como consequência da inibição da atividade da cadeia de transporte de elétrons; (3) alteração na permeabilidade das membranas interna e externa, tendo como consequência a liberação de proteínas pró apoptóticas confinadas no espaço 
intermembranoso como o citocromo c e Bax. Os AG podem induzir também redução dos conteúdos de glutationa, o que afeta a manutenção do estado redox da célula. Este quadro resulta em injúrias oxidativas associadas com a degeneração da mitocôndria (TRONSTAD et al., 2003). Em estudo realizado por Lima et al (2002), foi determinada a toxicidade de vários AG sobre linhagens de células leucêmicas humanas, Jurkat (linfócitos T) e Raji (linfócitos B). A toxicidade dos $A G$ não foi diferente entre os linfócitos $T$ e $B$, sendo esta, relacionada ao número de carbonos e de insaturações da cadeia. Os AG com maior número de carbonos e insaturações foram os mais citotóxicos.

Há evidências de que os AGL podem ativar a PKC e a expressão da FasL (ANEL;RICHIERI;KLEINFELD, 1994; WANG et al., 1998). A infusão de uma emulsão de lipídeos em ratos resulta em acúmulo intracelular de acil-CoA e diacilglicerol, que leva à ativação da PKC pela fosforilação do resíduo de serina da IRS-1 (YU et al., 2002). Hirabara et al (2003) demonstraram que em músculo sóleo de obtidos de ratos e incubados com palmitato, observa-se diminuição da fosforilação de IRS-1 e 2, Akt e proteína quinase ativada por mitógeno (MAPK) quando estimuladas com insulina. Dey et al (2005) observaram que na incubação do mesmo músculo com palmitato, a expressão do gene do receptor de insulina está diminuída bem como o número destes na membrana plasmática. 


\section{PROPOSTA DO ESTUDO}

O ácido palmítico é um dos $A G$ saturado mais abundantes da dieta e do plasma. A concentração plasmática deste ácido graxo é elevada no jejum e em patologias como o diabetes, câncer, isquemia e sepse. $O$ aumento da concentração de ácidos graxos livres pode alterar as funções de células bem como induzir morte celular.

O presente estudo tem como objetivo avaliar o metabolismo e os mecanismos envolvidos na apoptose de linfócitos induzida pela exposição ao ácido palmítico. Além disso, serão investigados os possíveis mecanismos antiapoptóticos tais como: expressão do receptor de insulina (IR) e GLUT4 e acúmulo de triacilgliceróis. 


\section{OBJETIVOS}

1) Investigar os efeitos do ácido palmítico (PA) na via de sinalização da apoptose:

- Ativação de caspases e PKC-ס,

- Liberação de citocromo c,

- Ativação das via das MAPK (JNK, ERK, p38 MAPK) e

2) Avaliar o efeito do PA sobre o estresse oxidativo e nitrosativo

3) Investigar os possíveis mecanismos de sobrevivência ativados durante a indução de morte celular pelo PA.

4) Avaliar a modulação da via de sinalização à insulina pelo PA. 


\section{MATERIAL E MÉTODOS}

\subsection{LINHAGENS CELULARES}

As células de linhagem leucêmica humana (Jurkat) e macrófagos de ratos (J774) foram mantidos em crescimento de fase log em estufa a $37{ }^{\circ} \mathrm{C}$ com atmosfera de $\mathrm{CO}_{2}$ a $5 \%$. Estas foram cultivadas em meio RPMI-1640 suplementado com soro fetal bovino a 10\%, 5,6 mM de glicose, $2 \mathrm{mM}$ de glutamina, $20 \mathrm{mM}$ de HEPES, $10 \mathrm{U} / \mathrm{mL}$ de ampicilina e $10 \mu \mathrm{g} / \mathrm{mL}$ de estreptomicina. A população celular foi mantida entre $1 \times 10^{5}$ e $1 \times 10^{6}$ células por $\mathrm{mL}$.

\subsection{OBTENÇÃO E PREPARAÇÃO DE LINFÓCITOS HUMANOS}

Linfócitos foram isolados do sangue periférico $(10 \mathrm{~mL})$ de voluntários sadios e diluídos em volume igual de tampão fosfato (PBS). Sobre a solução foram colocados $10 \mathrm{~mL}$ de Lymphoprep $(\mathrm{d}=1.077$ ) (Sigma Chemical Co, St Louis, MO, USA). Os tubos foram centrifugados a $1200 \mathrm{rpm}$ a $4{ }^{\circ} \mathrm{C}$, por $30 \mathrm{~min}$, e o sobrenadante, rico em células mononucleares, foi separado e submetido a incubação em frasco de cultura com meio RPMI-1640 por $1 \mathrm{~h}$ a $37{ }^{\circ} \mathrm{C}$ em atmosfera humidificada com $5 \%$ de $\mathrm{CO}_{2}$. Este procedimento permite que monócitos sejam aderidos à superfície do frasco. $O$ meio foi centrifugado a $1200 \mathrm{rpm}$ a $4{ }^{\circ} \mathrm{C}$, por $10 \mathrm{~min}$, e os linfócitos ressuspendidos em PBS. O número de linfócitos viáveis (>95\%) foi determinado utilizando o corante azul de Tripan.

\subsection{OBTENÇÃO E PREPARAÇÃO DE LINFÓCITOS DE RATOS}

Foram utilizados ratos machos da linhagem Wistar (Rattus norvegicus). Os animais foram mantidos em gaiolas coletivas ( 5 animais por gaiola) em ambiente climatizado $\left(22^{\circ} \mathrm{C}\right)$ e com controle de luminosidade (12h escuro: $12 \mathrm{~h}$ iluminado), recebendo alimentação balanceada (contendo $52 \%$ de carboidratos, $21 \%$ de proteínas e $4 \%$ de lípides - Nuvilab CR1-Nuvital $\circledast$ ) e água ad libitum. 
Como modelo experimental, os animais foram mantidos em jejum por $48 \mathrm{~h}$ e sacrificados por decapitação. O sangue foi colhido e o plasma foi separado e estocado para posterior análise.

Os linfócitos foram obtidos à partir dos linfonodos mesentéricos pressionando o tecido linfóide entre duas malhas de aço inoxidável, conforme Vieira et al., (1990), que resulta em uma preparação contendo pelo menos 95\% de linfócitos (ARDAWI e NEWSHOLME, 1983). As células foram coletadas em PBS e centrifugadas por $10 \mathrm{~min}$, a $1200 \mathrm{rpm}$ a $4{ }^{\circ} \mathrm{C}$. O precipitado foi ressuspenso em meio RPMI 1640.

\subsection{TRATAMENTO DAS CÉLULAS}

A suspensão celular foi transferida para placas de 24 poços adicionandose $2 \mathrm{~mL}$ desta em cada um. As placas foram incubadas por 24 horas em estufa a $37^{\circ} \mathrm{C}$ com atmosfera de $\mathrm{CO}_{2}$ a $5 \%$, obtendo-se ao final do período, cerca de $8 \times 10^{5}$ células/mL em cada poço. Em cada um destes foi adicionado o PA, previamente diluído em etanol, nas concentrações de 50, 100 ou $150 \mu \mathrm{M}$. O etanol é utilizado sempre abaixo de $0,05 \%$ do volume total do meio contendo as células. Foi observado que, nesta concentração, o etanol não é citotóxico (LIMA et al., 2002).

\subsection{ANÁLISE MORFOLÓGICA}

Após tratamento com PA por 24h, foram confeccionadas lâminas histológicas das células Jurkat. As suspensões celulares foram citocentrifugadas e coradas pelo método de May-Grunwald-Giemsa para análise de alterações nucleares e citoplasmáticas.

\subsection{AVALIAÇÃO DAATIVIDADE MITOCONDRIAL}

O ensaio da atividade mitocondrial foi realizado usando-se o método de redução do reagente WST-1 (Roche Diagnostics, Mannheim, Alemanha). Este sal tetrazólico é convertido em formazan pela atividade da desidrogenase mitocondrial. O aumento no número de células viáveis resulta em aumento da atividade total da desidrogenase. Neste ensaio, as células Jurkat $\left(2 \times 10^{4}\right)$ foram 
colocadas em uma placa escura de 96 poços por $24 \mathrm{~h}$ em estufa a $37^{\circ} \mathrm{C}$ com atmosfera de $\mathrm{CO}_{2}$ a $5 \%$, obtendo-se, ao final do período, cerca de $4 \times 10^{4}$ células em cada poço. As células foram tratadas com PA por $24 \mathrm{~h}$, e no final da

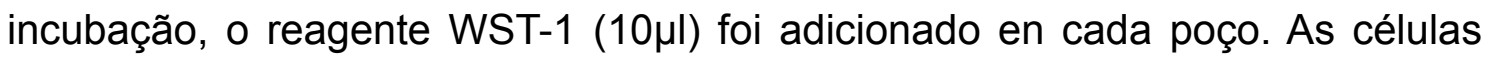
foram incubadas por $1 \mathrm{~h}$ em estufa a $37{ }^{\circ} \mathrm{C}$ e o formazan produzido foi quantificado avaliando-se sua absorbância a 450nm utilizando-se um leitor de placas Spectramax Plus (Molecular Devices, Sunnyvale, CA, EUA).

\subsection{ANÁLISE DA FRAGMENTAÇÃO DE DNA}

Durante o processo apoptótico é observado a fragmentação do DNA e pode ser detectado utilizando-se o iodeto de propídeo $(\mathrm{PI})$, um composto fluorescente que se intercala eficientemente entre bases nitrogenadas. O DNA fragmentado, caracteriza-se por partículas altamente condensadas nos quais o fluoróforo não consegue ligar-se eficientemente às bases nitrogenadas e mostram-se como partículas pouco fluorescentes.

A avaliação da fragmentação de DNA foi realizada de acordo com método descrito por Nicoletti et al. (1991). Após o tratamento com PA, as células foram centrifugadas (Spin I, Incibrás, São Paulo) a alta velocidade (12000 rpm) por 20 segundos e o precipitado ressuspendido em tampão fosfato. Após uma nova centrifugação, este foi ressuspenso em $0,2 \mathrm{~mL}$ de tampão de lise $(0,1 \%$ de citrato de sódio e $0,1 \%$ de Triton X-100) e PI a $100 \mu \mathrm{g} / \mathrm{mL}$. As células foram incubadas em temperatura ambiente no escuro por 30 minutos e a fluorescência foi medida em um citômetro de fluxo FACScalibur (Becton Dickinson, CA, EUA), utilizando o software Cell Quest (Becton Dickinson). Para cada teste, foram avaliados dez mil eventos.

\subsection{ENSAIO DA ATIVIDADE DA ENZIMA LACTATO DESIDROGENASE (LDH)}

O ensaio da atividade de LDH tem como finalidade mensurar a citotoxicidade e a lise celular através da detecção da atividade da enzima liberada pelo citossol de células danificadas. Após tratamento com PA por $24 \mathrm{~h}$, as células Jurkat foram centrifugadas a $250 \times g$ e o sobrenadante recolhido. Alíquotas de $100 \mu \mathrm{L}$ foram transferidas para uma placa de 96 poços e a estas 
$100 \mu \mathrm{L}$ da mistura de reação (diaforese/NAD ${ }^{+}$, iodotetrazolium de cloro e lactato de sódio) do kit LDH-Cytotoxicity Assay (Biovision Research, Mountain View, CA, EUA) foram adicionados. A placa foi incubada à temperatura ambiente por 30min e a absorbância lida imediatamente a 490nm.

\subsection{AVALIAÇÃO DA DESPOLARIZAÇÃO DA MEMBRANA MITOCONDRIAL}

Células Jurkat, após tratamento com PA, foram centrifugadas a $1000 \times g$, por $15 \mathrm{~min}$, a $4{ }^{\circ} \mathrm{C}$ e o precipitado obtido foi ressuspendido em $1 \mathrm{~mL}$ de PBS. Rodamina 123 é um corante fluorescente que é rapidamente sequestrado pela mitocôndria ativa sem induzir efeitos citotóxicos. A captação e o equilíbrio da rodamina 123 ocorrem rapidamente. Portanto, este fluoróforo permite uma deteç̧ão rápida de mudanças no potencial de membrana da mitocôndria. A rodamina $123(5 \mu \mathrm{M})$ foi adicionada às células e incubadas por $15 \mathrm{~min}$ a $37^{\circ} \mathrm{C}$ no escuro. Em seguida, as células foram lavadas e incubadas com PBS gelado por $30 \mathrm{~min}$ no escuro. A fluorescência da rodamina 123 foi determinada por citometria de fluxo utilizando o canal FL1 (530/30nm).

\subsection{AVALIAÇÃO DA DISTRIBUIÇÃO DO CITOCROMO C}

Para a detecção da redistribuição do citocromo c, as frações citossólica e mitocondrial foram isoladas das células Jurkat utilizando tampão de lise (250 $\mathrm{mM}$ sacarose, $70 \mathrm{mM} \mathrm{KCl} \mathrm{e} 2 \mathrm{mg} / \mathrm{mL}$ de digitonina em PBS). A suspensão celular foi centrifugada a $250 \mathrm{~g}$, por $5 \mathrm{~min}$, a $4^{\circ} \mathrm{C}$. O sobrenadante contendo a fração citossólica foi removida e armazenada a $-70{ }^{\circ} \mathrm{C}$. O precipitado foi ressuspendido em tampão de imunoprecipitação (100 mM Tris-HCl, pH 7.0; 10 mM EDTA; $100 \mathrm{mM} \mathrm{NaF} ; 10 \mathrm{mM}$ pirofosfato de sódio; $10 \mathrm{mM}$ ortovanadato de sódio e $0.1 \mathrm{mM}$ PMSF) e mantido em gelo por $10 \mathrm{~min}$. À seguir, a suspensão foi centrifugada a $12,000 \mathrm{rpm}$, por $10 \mathrm{~min}$, a $4{ }^{\circ} \mathrm{C}$ e o sobrenadante armazenado a $-70{ }^{\circ} \mathrm{C}$ como fração mitocondrial. As frações foram submetidas ao ensaio de western blotting. 


\subsection{WESTERN BLOTTING}

Após o término do período de incubação, as células foram homogeneizadas em tampão de extração (Tris-base 10 mM, pH 7.5; EDTA 0,5 $\mathrm{mM}$; fluoreto de sódio $100 \mathrm{mM}$; pirofosfato de sódio $10 \mathrm{mM}$; ortovanadato de sódio $10 \mathrm{mM}$; PMSF $2 \mathrm{mM}$; aprotinina $0,01 \mathrm{mg} / \mathrm{ml}$ ) a $4{ }^{\circ} \mathrm{C}$. Em seguida, Triton $\mathrm{X}$ 100 a $1 \%$ foi adicionado aos homogeneizados. Após incubação a $4^{\circ} \mathrm{C}$, por $30 \mathrm{~min}$, as amostras foram centrifugadas a $12,000 \mathrm{rpm}$, a $4{ }^{\circ} \mathrm{C}$, por 20 minutos e os sobrenadantes submetidos à quantificação protéica pelo método de Bradford (1976), usando curva de albumina como padrão. Alíquotas das amostras contendo a mesma quantidade de proteínas foram submetidas a processo de eletroforese em gel de poliacrilamida SDS-PAGE (LAEMMLI, 1970), utilizando tampão de corrida (trisma base 50mM; glicina 0,38 M; EDTA $1,8 \mathrm{mM}$; SDS $0,1 \%$ ). As proteínas fracionadas foram transferidas para uma membrana de nitrocelulose, utilizando tampão de transferência (trisma base 25mM; glicina 192 mM; metanol 20\%) e tensão de 100 V. A transferência foi avaliada por coloração com Ponceau-S.

Para a avaliação das proteínas citocromo c, PKC- $\delta$, Caspases 3 e 9, JNK, p-JNK, P38 MAPK, p-P38 MAPK, ERK1/2, p-ERK1/2, Akt, p-Akt, IRS-1, pIRS-1 e $\beta$-Actina, a membrana foi bloqueada durante uma noite a $4^{\circ} \mathrm{C}$ em tampão TBS-T (10 mM Tris- $\mathrm{HCl}, \mathrm{pH} 7.0 ; 150 \mathrm{mM} \mathrm{NaCl} ; 0.05 \%$ Tween 20) contendo $5 \%$ de leite desnatado. A membrana foi incubada por 1 hora à temperatura ambiente com diluições adequadas dos anticorpos primários, em TBS-T contendo $5 \%$ de leite desnatado. Posteriormente, a membrana foi lavada 3 vezes por 10 minutos com PBS-T. A seguir, a membrana foi incubada com anticorpos secundários conjugados com peroxidase, em PBS-T contendo $5 \%$ de leite desnatado. Após três lavagens de 10 minutos com PBS-T, a membrana foi tratada com o substrato Amersham ECL (GE Healthcare, Buckinghamshire, Inglaterra) por $1 \mathrm{~min}$ e revelada em um filme de raio-X de maneira convencional.

Para a avaliação das proteínas $A M P K, p-A M P K$, iNOS e GAPDH, após separação das proteínas por eletroforese em gel de poliacrilamida e transferência em membrana de nitrocelulose, esta foi colocada no sistema 
SNAP id Protein Detection System (Millipore, EUA). A membrana foi bloqueada utilizando-se tampão TBS-T contendo $0.3 \%$ de leite desnatado por $10 \mathrm{~min}$. À seguir, a membrana foi incubada com os anticorpos primários por 10 min. Após a incubação, a membrana foi lavada com TBS-T e imediatamente incubada com o anticorpo secundário por $10 \mathrm{~min}$. Após lavagem com TBS-T, a membrana foi tratada com o reagente quimioluminescente do kit Pierce ECL western blot substrate (Pierce, Rockford, IL) por 5 min e revelada em um filme de raio-X de maneira convencional.

As intensidades das bandas foram quantificadas por densitometria óptica pelo uso do programa Image J (Frederich, Maryland, EUA).

\subsection{IMUNOPRECIPITAÇÃO}

Alíquotas das diferentes amostras, com a mesma concentração de proteínas totais, foram utilizadas para imunoprecipitação com anticorpos para receptor de insulina (IR) e p-IR e GLUT-4, por 12 horas, a $4{ }^{\circ} \mathrm{C}$ sob agitação. Os imunocomplexos formados são precipitados com proteína $A$ Sepharose $6 M B$ (GE Healthcare) e, em seguida, submetidos à eletroforese em $6 \%$ SDSPAGE. Em seguida, as proteínas do gel foram transferidas eletricamente para uma membrana de nitrocelulose para a realização do Western Blotting.

\subsection{ENSAIO DO RETARDAMENTO DA MOBILIDADE ELETROFORÉTICA (EMSA) PARA O NF-kB}

Neste ensaio, proteínas do extrato nuclear ligam-se a uma seqüência específica de nucleotídeos com o seu fator de transcrição, sendo esta previamente marcada com ${ }^{32} \mathrm{P}$ pela $\mathrm{T}_{4}$ polinucleotídeo quinase. Quando este complexo DNA-proteína é submetido a uma eletroforese em gel de poliacrilamida, a sonda livre (oligonucleotídeo) migra mais do que a sonda ligada ao fator nuclear (banda de retardo).

Os extratos nucleares das células tratadas com PA foram obtidos utilizando método descrito por Andrew e Faller (1991). Para a marcação da sonda, o oligonucleotídeo de DNA para o NF-KB contendo a seqüência 5'AGTTGAGGGGACTTTCCCAGGC-3' foi marcado com [Y-32P]ATP (GE Healthcare) em solução tampão T4 quinase. A sonda $(30,000 \mathrm{cpm})$ foi ligada a 
$10 \mu \mathrm{g}$ de proteína nuclear à temperatura ambiente, por $20 \mathrm{~min}$, em $20 \mu \mathrm{L}$ de tampão de ligação consistindo de 20 mM HEPE, pH 7,6, $50 \mathrm{mM} \mathrm{KCl,} \mathrm{10 \%}$ glicerol, 0,2 mM EDTA, 1 mM DTT e $2 \mu \mathrm{g}$ ácido polideoxinosínico-deoxicitidilico (poly[dl-dC]). Ensaio de ligação de competidor foi conduzido de mesma forma com a adição de 2 pmol de oligonucleotídeo sem marcação. Os complexos DNA-proteína foram submetidos a processo de eletroforese em gel de poliacrilamida a $4 \%, 4{ }^{\circ} \mathrm{C}$, em tampão contendo $45 \mathrm{mM}$ Tris, $45 \mathrm{mM}$ ácido bórico e $1 \mathrm{mM}$ EDTA. Ao final da corrida, o gel foi seco e autoradiografados. As autoradiografias foram escaneadas e analisadas com o programa Image $\mathrm{J}$.

\subsection{AVALIAÇÃO DA ABUNDÂNCIA DO RECEPTOR DE INSULINA E DE GLUT-4 POR CITOMETRIA DE FLUXO}

Após o período de tratamento as células os mesmos foram centrifugadas e o precipitado ressuspendido em PBS contendo anticorpo para IR ou GLUT-4 na proporção 1:50 e incubado no escuro a $4{ }^{\circ} \mathrm{C}$ por 1 hora. Em seguida, as células foram lavadas e incubadas com anticorpo secundário conjugado com o fluoróforo FITC na proporção 1:50, no escuro por 1 hora a $4^{\circ} \mathrm{C}$. Após este período, as células foram lavadas e ressuspendidas em PBS e analisadas por citometria de fluxo no canal FL1.

\subsection{DETERMINAÇÃO DA CAPTAÇÃO DE GLICOSE}

Após tratamento com PA, $1 \times 10^{6}$ células foram transferidas para tubos eppendorffs e os mesmos incubados na presença ou não de insulina $(10 \mathrm{mU} /$ $\mathrm{mL}$ ) por 25 minUTOS. Subseqüentemente, PBS contendo 0,5 mM 2-deoxi-Dglicose e 0,5 $\mathrm{CCi}$ 2-[1, 2 -3H] deoxi-D-glicose foram adicionados às células por 5 min. As incubações foram interrompidas com a adição de citocalasina $B$ (concentração final de $50 \mu \mathrm{M}$ ). As células foram separadas do meio de incubação contendo o radioativo por centrifugação a 5,000 rpm por 30 s. Uma alíquota de células foi utilizada para determinar a concentração de proteínas de cada amostra utilizando o método de Bradford. As células e o meio de incubação foram transferidas para tubos de cintilação e a radioatividade foi mensurada em um contador de cintilação Beckman-LS 5000 TD (Beckman Instruments, Fullerton, CA, EUA). 


\subsection{ENSAIO DA OXIDAÇÃO DE D-[U- $\left.{ }^{14} \mathrm{C}\right]$ GLICOSE}

A oxidação de glicose foi determinada a partir da conversão de D-[U- $\left.{ }^{14} \mathrm{C}\right]$ glicose à ${ }^{14} \mathrm{CO}_{2}$. Células $\left(1 \times 10^{6}\right)$, após tratamento com $\mathrm{PA}$, foram incubadas por $1 \mathrm{~h}$ a $37^{\circ} \mathrm{C}$ em tubos de cintilação contendo $1 \mathrm{~mL}$ de PBS com 5,6 mM de glicose e $0,2 \mu \mathrm{Ci} / \mathrm{mL} \mathrm{D}-\left[\mathrm{U}-{ }^{14} \mathrm{C}\right]$ glicose na presença ou ausência de insulina (10 $\mathrm{mU} / \mathrm{mL}$ ). No interior dos frascos, foram adicionados um pedaço de papel de filtro umedecido com solução de 2-feniletilamina/metanol (1:1, v/v). Após 1 hora de incubação, o meio foi acidificado com $0,4 \mathrm{~mL}$ de $\mathrm{HCl}(5 \mathrm{~N})$. Os frascos foram selados e mantidos a $37{ }^{\circ} \mathrm{C}$ por 30 minutos. Ao término deste período, os papéis de filtro foram removidos e transferidos para tubos de cintilação para a mensuração da radioatividade.

\subsection{DETERMINAÇÃO DO CONSUMO DE GLICOSE E DE GLUTAMINA E DA PRODUÇÃO DE LACTATO E GLUTAMATO}

Após tratamento com PA por $24 \mathrm{~h}$ as células Jurkat foram centrifugadas a $12,000 \mathrm{rpm}$ por 10 minutos e o sobrenadante recolhido. A mensuração dos metabólitos foi realizada utilizando o aparelho YSI 7100 Biochemistry Analyzer (YSI Life Sciences, Yellow Springs, OH, EUA) que possui sensores específicos para cada um. Os sensores possuem enzimas específicas que ficam imobilizadas entre uma membrana de policarbonato e de acetato de celulose para cada metabólito. O metabólito reage com a enzima produzindo peróxido de hidrogênio que atravessa a membrana de acetato de celulose e entra em contato com um eletrodo de platina. O peróxido de hidrogênio é então oxidado e a corrente elétrica resultante é proporcional à concentração do substrato. 

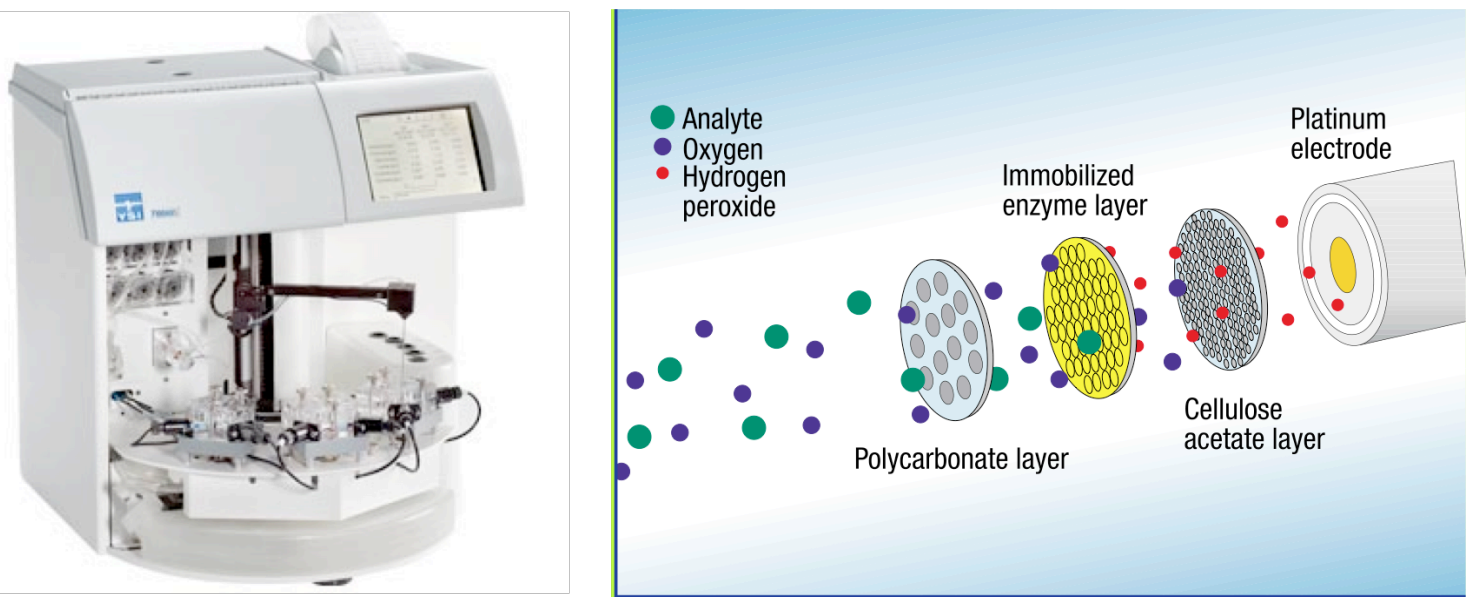

Figura 3. Ilustração do aparelho YSI 7100 e o esquema representativo da composição do sensor. 


\subsection{ANÁLISE QUALITATIVA DO CONTEÚDO DE TRIACILGLICERÓIS}

Após tratamento com PA, as células foram citocentrifugadas em lâminas para microscopia e em seguida fixadas por 15 minutos com solução de paraformaldeído a $3,7 \%$. As lâminas foram então lavadas e coradas com o corante Oil Red, que possui a capacidade de se ligar às moléculas de triacilgliceróis, por 10 minutos. Após este período, as lâminas foram lavadas e coradas com hematoxicilina por 10 minutos. À seguir, as lâminas foram lavadas, secas e observadas em microscópio óptico.

\subsection{DETERMINAÇÃO DO ACÚMULO INTRACELULAR DE LIPÍDEOS NEUTROS}

As células foram centrifugadas a $1000 \mathrm{~g}$ por 15 minutos a $4{ }^{\circ} \mathrm{C}$ e o precipitado ressuspenso em $500 \mu \mathrm{L}$ de PBS. Nile Red $(0,1 \mu \mathrm{g} / \mathrm{mL})$, um corante fluorescente seletivo para gotículas lipídicas intracelulares foi adicionado e a fluorescência foi determinada através de análise por citometria de fluxo utilizando o canal FL1.

\subsection{INCORPORAÇÃO DE $\left[{ }^{14} \mathrm{C}\right]$-PALMITATO EM FRAÇÕES LIPÍDICAS}

As células foram tratadas com PA $(50,100$ e $150 \mu \mathrm{M})$ junto com $0,5 \mu \mathrm{Ci}$ $\left[{ }^{14} \mathrm{C}\right]$-palmitato por 24 horas. Após o período de incubação, as células foram submetidas à uma extração lipídica utilizando o método de Folch et al., (1957). Os extratos lipídicos foram ressuspensos em $50 \mu \mathrm{L}$ de solução de clorofórmio/ metanol $(2: 1, v / v)$ e cromatografados utilizando placa de cromatografia de camada delgada com fase estacionária de $250 \mu \mathrm{m}$ de sílica gel (Sigma Chemical Co) e fase móvel constituída de hexano/dietil éter/ ácido acético (70:30:1, v/v/v). A placa foi mantida em uma câmara contendo iodo para a visualização das frações lipídicas. Estas frações foram gentilmente raspados da placa de sílica e transferidos para frascos de cintilação para a determinação da radioatividade. 


\subsection{DETERMINAÇÃO DA COMPOSIÇÃO DE ÁCIDOS GRAXOS EM CÉLULAS JURKAT E PLASMA DE RATOS}

As células tratadas com PA $(50,100$ e $150 \mu \mathrm{M})$ ou plasma de ratos foram submetidos à extração lipídica utilizando o método de Folch. Os lipídeos foram saponificados utilizando $2 \mathrm{~mL}$ de uma solução metanólica alcalina (solução de $1 \mathrm{M}$ de $\mathrm{NaOH}$ em $90 \%$ de metanol), a $37^{\circ} \mathrm{C}$, por 2 horas em banho-maria sob agitação. Após este período, a solução alcalina foi acidificada com solução $1 \mathrm{M}$ de $\mathrm{HCl}$. Os ácidos graxos foram extraídos com a adição de $2 \mathrm{~mL}$ de hexano e secos em speed-vac e armazenados a $-20{ }^{\circ} \mathrm{C}$. Para o processo da determinação da composição de ácidos graxos, as amostras foram ressuspendidas em acetonitrila e derivatizadas com 4-bromometil-7-cumarina. A análise foi realizada em um cromatógrafo líquido de alta performance (HPLC) Shimadzu LC-10A acoplado a um detector de fluorescência Shimadzu RF-55XL. As amostras foram eluídas utilizando uma coluna C8 de fase reversa ( $25 \mathrm{~cm} \times 4,6$ i.d., partículas de $5 \mu \mathrm{m})$ com pré-coluna C 8 de fase reversa $(2,5 \mathrm{~cm}$ x 4,6 i.d., partículas de $5 \mu \mathrm{m}$ ), e fase móvel com velocidade de $1 \mathrm{~mL}$ de solução de acetonitrila/água $(70: 30, v / v)$.

\subsection{QUANTIFICAÇÃO DE ÁCIDOS GRAXOS LIVRES DE PLASMA DE RATOS}

Os ácidos graxos livres foram quantificados utilizando o kit NEFA-HR (Wako Diagnostics, Richmond, VA, EUA). Neste método, os ácidos graxos não esterificados quando tratados com a enzima acil-CoA sintetase, na presença de ATP e CoA, formam acil-CoA que são oxidados pela acil-CoA oxidase produzindo peróxido de hidrogênio. Este, na presença da enzima peroxidase, permite a condensação oxidativa da 3-metil-N-etil-N-hidroximetil-anilina (MEHA) com a 4-aminoantipirina formando um composto de cor roxa que possui absorbância máxima a 550nm.

Para o ensaio, alíquotas de $20 \mu \mathrm{L}$ de plasma foram transferias a uma placa de 96 poços e os reagentes foram adicionados conforme o manual do 
fabricante. A absorbância das amostras foi lida a $450 \mathrm{~nm}$ utilizando-se um leitor de placas Spectramax Plus (Molecular Devices).

\subsection{DETERMINAÇÃO DA PRODUÇÃO DE SUPERÓXIDOS}

Após o tratamento com PA as células foram incubadas com diidroetidina $(100 \mu \mathrm{M})$ por 30 minutos sob agitação no escuro. A diidroetidina, em contato com superóxidos, é rapidamente oxidada a etídeo que se intercala ao DNA levando à emissão de fluorescência pela célula. Em seguida, as células foram analisadas em citômetro de fluxo utilizando o canal FL3 (670nm).

\subsection{ENSAIO DA PRODUÇÃO DE PERÓXIDO DE HIDROGÊNIO}

A determinação da produção de peróxido de hidrogênio nas células tratadas com PA foi realizada utilizando o kit Amplex Red (Molecular Probes) seguindo as instruções do fabricante. As células foram centrifugadas e incubadas em tampão contendo o corante Amplex Red e peroxidase. Na presença do peróxido de hidrogênio, há a formação de um composto fluorescente, a resorufina. A detecção deste composto foi feita em fluorímetro utilizando como comprimento de onda de absorção e emissão, respectivamente, 563 e $587 \mathrm{~nm}$.

\subsection{ENSAIO DA PRODUÇÃO DE NITRITO}

O óxido nítrico (NO) é um composto muito instável e sua produção foi mensurada indiretamente pela quantificação de nitrito, um composto de degradação do NO estável e não-volátil, através da reação modificada de Griess (1879). Este método consiste na reação da sulfanilamida com o nitrito produzindo um composto que em contato com o dicloroidrato de $\mathrm{N}$-1naftiletilenodiamina (NED), em condições acídicas catalisa uma reação de diazotização formando um composto que pode ter sua absorbância lida a 520 $\mathrm{nm}$.

Após o tratamento com PA, as células Jurkat foram centrifugadas a 12,000 rpm por 5 minutos e o sobrenadante recolhido. O nitrito foi quantificado utilizando-se o kit Griess Reagent System (Promega, Madison, WI, EUA). As 
células foram lisadas com tampão de lise para a quantificação de proteína. Os resultados foram expressos em $\mu \mathrm{M}$ de nitrito/ mg de proteína.

\subsection{QUANTIFICAÇÃO DO CONTEÚDO INTRACELULAR DE GLUTATIONA REDUZIDA (GSH) E OXIDADA (GSSG)}

A determinação do conteúdo intracelular de GSG e GSSG foi realizada utilizando o método descrito por Rahman et al. (2007). O ensaio baseia-se na reação enzimática do GSH com DTNB [5'-5'-ditio-bis-(2-ácido nitrobenzóico)], também conhecido como reagente de Ellman, que produz o cromóforo TNB e o aduto oxidado glutationa-TNB (GS-TNB). A taxa de formação do TNB , avaliada a $412 \mathrm{~nm}$ é proporcional à concentração de GSH na amostra. O produto GSTNB é reduzido pela enzima Glutationa Redutase (GR) na presença de $\beta$ NADPH, reciclando o GSH de volta para a reação.

Após o tratamento das células Jurkat com PA, estas foram lisadas em tampão de extração $(0,1 \%$ Triton $X-100$ and $0,6 \%$ ácido sulfosalicílico em tampão fosfato de potássio $0.1 \mathrm{M}$ contendo $5 \mathrm{mM}$ de EDTA disódico, $\mathrm{pH} 7.5$ ) por 15 min sob agitação e centrifugadas a 12,000 rpm por 10 min. O sobrenadante foi colhido e estocado a $-80^{\circ} \mathrm{C}$. Uma alíquota foi guardada para a quantificação de proteínas.

Para o quantificação de GSH, as amostras e padrões da enzima foram adicionados a uma placa de 96 poços com a mistura de reação (RM) contendo DTNB, $\beta$-NADPH, GR e incubada à temperatura ambiente por 5 min. A absorbância foi lida a $412 \mathrm{~nm}$ utilizando um leitor de placas Spectramax Plus (Molecular Devices).

Para a determinação de GSSG, as amostras e os padrões foram incubados com 2-vinilpiridina e trietanolamina por $1 \mathrm{~h}$ em temperatura ambiente para a conversão em GSH e transferidos para uma placa de 96 poços com a RM. A placa foi incubada à temperatura ambiente por 5 min e a absorbância lida a $412 \mathrm{~nm}$. Os resultados foram expressos como $\mu \mathrm{g} / \mathrm{mg}$ de proteína.

\subsection{ANÁLISE ESTATÍSTICA}

Os dados serão apresentados como média \pm erro padrão da média (EPM) e analisados por ANOVA one way com pós-teste de Tukey, $(p<0,05)$ ou ANOVA 
two way com pós-teste de Bonferroni $(p<0,05)$ para os teste pareados e pelo teste de Student para os testes não pareados com $p<0,05$. 


\section{RESULTADOS}

\subsection{CARACTERIZAÇÃO DA MORTE CELULAR}

\subsubsection{Efeito da incubação com PA sobre a fragmentação de DNA nas}

células Jurkat

A fragmentação de DNA é uma das características das células em processo de apoptose. A incubação com PA (50, 100 e $150 \mu \mathrm{M})$ elevou a proporção de células com DNA fragmentado (Figura 4A). Correlação positiva é observada quanto à concentração de PA e porcentagem de células com DNA fragmentado (Figura 4B).

A

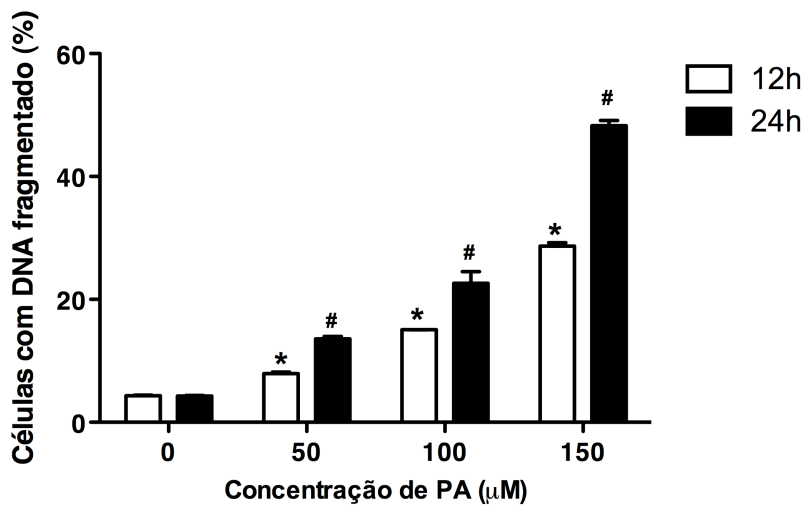

B

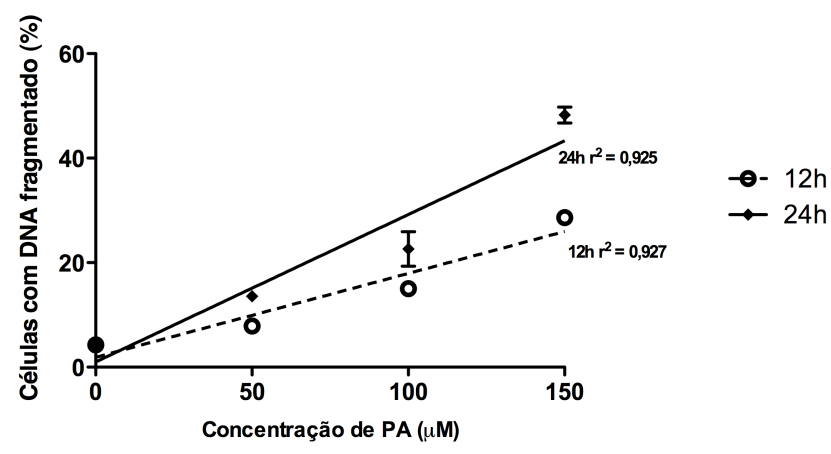

Figura 4 - Análise da fragmentação de DNA. A) Avaliação por citometria de fluxo do efeito do PA sobre a fragmentação de DNA de células Jurkat nos períodos de 12 e $24 \mathrm{~h}$. Resultados estão expressos como média \pm E.P.M de $n=6$ ensaios. ${ }^{*} p<0,05$ quando comparado ao controle; ${ }^{*} p<0,001$ quando comparado com o respectivo grupo de 12h. B) Correlação entre a concentração de PA e porcentagem de células Jurkat com DNA fragmentado nos períodos de 12 e $24 \mathrm{~h}\left(\mathrm{r}^{2}=0,925\right.$ e 0,927 , respectivamente). 


\subsubsection{Efeito do PA sobre a atividade mitocondrial nas células Jurkat}

As células viáveis possuem a capacidade de reduzir o reagente WST-1 em formazan através da enzima desidrogenase mitocondrial. O formazan pode ser quantificado através de sua absorbância e a sua formação está diretamente ligada à viabilidade celular e a atividade mitocondrial. $\mathrm{O}$ tratamento das células Jurkat por 24h com PA, no entanto, indica uma diminuição na absorbância de maneira dose-dependente, indicando a perda da viabilidade celular e redução da atividade mitocondrial.

A
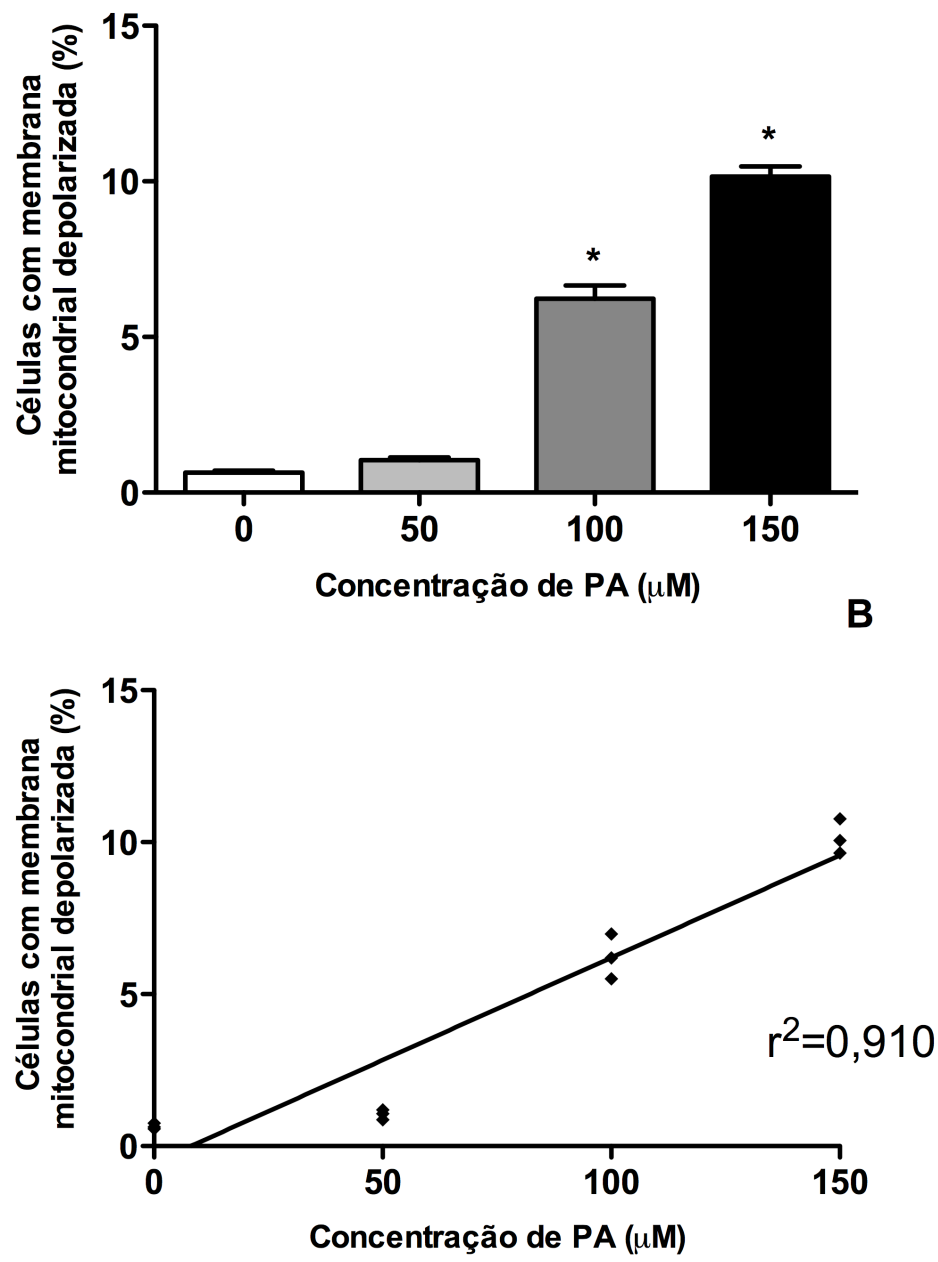

Figura 5 - Análise da atividade mitocondrial. A) Avaliação do efeito do PA sobre a atividade mitocondrial de células Jurkat através do método de redução do reagente WST-1 à formazan. Resultados estão expressos como média \pm E.P.M de $n=6$ ensaios. * $p<0,0001$ quando comparado ao controle. B) Correlação entre a concentração de PA e a atividade mitocondrial $\left(r^{2}=0,86\right)$. 


\subsubsection{Efeito do PA sobre a proporção de células Jurkat em Necrose}

A detecção do aumento da atividade da LDH no sobrenadante das células é indicativo de necrose devido ao processo de lise celular e extravasamento de seu conteúdo. Foi observado que o tratamento com PA levou ao aumento da atividade da LDH de maneira dose-dependente.

A

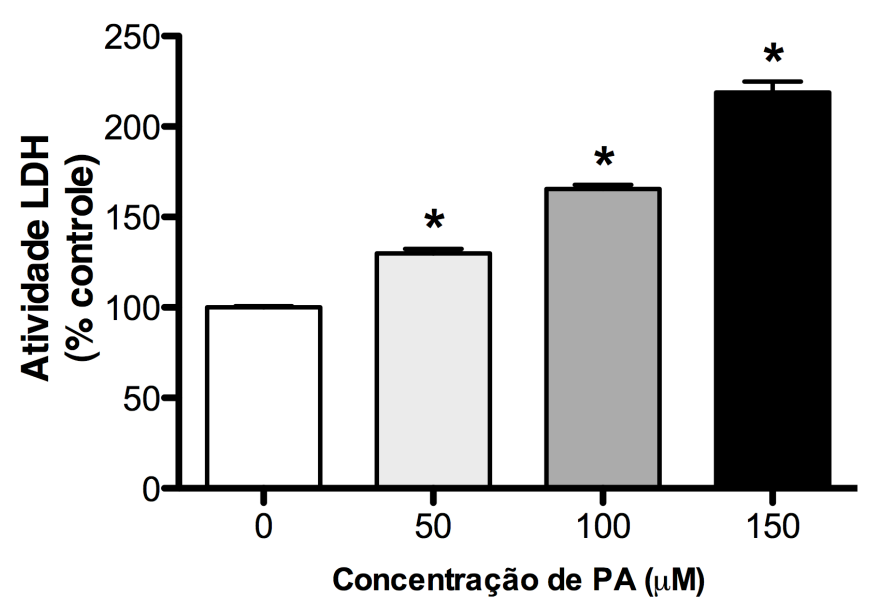

B

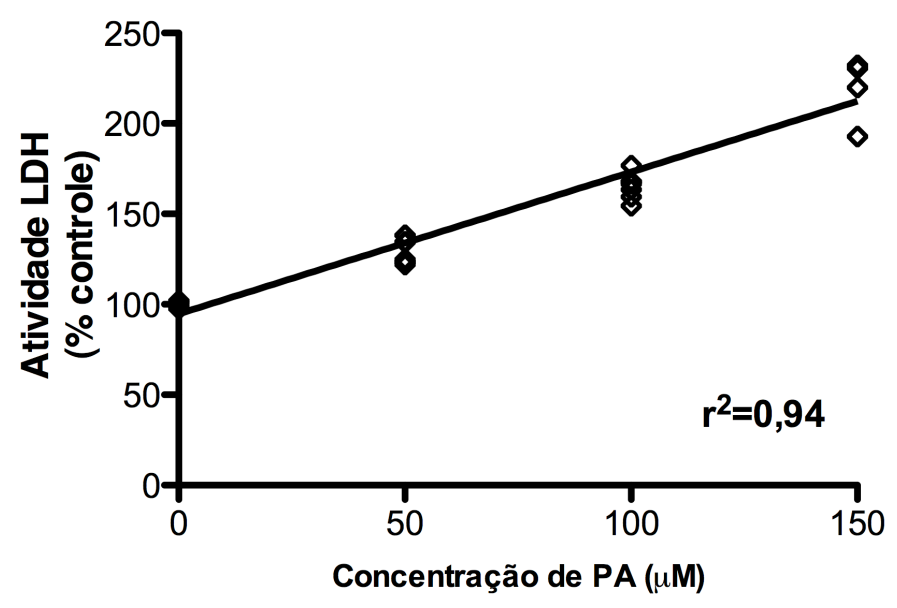

Figura 6 - Análise da atividade de LDH no sobrenadante A) Avaliação do efeito do PA sobre a proporção de células Jurkat em necrose através da determinação da atividade da LDH. Resultados estão expressos como média \pm E.P.M de $n=6$ ensaios. * $p<0,0001$ quando comparado ao controle. B) Correlação entre a concentração de PA e porcentagem de células Jurkat viáveis $\left(r^{2}=0,94\right)$. 


\subsubsection{Efeito do PA sobre a despolarização da membrana mitocondrial}

A perda do potencial de membrana mitocondrial é também uma das características de células em apoptose, permitindo a liberação do conteúdo mitocondrial como o citocromo c que pode ativar mecanismos de morte como a via das caspases. As células $\left(1 \times 10^{6}\right)$ foram incubadas com rodamina 123 (5 $\mu \mathrm{M})$. A incubação com PA aumentou a porcentagem de células com membrana mitocondrial despolarizada à partir de $100 \mu \mathrm{M}$.

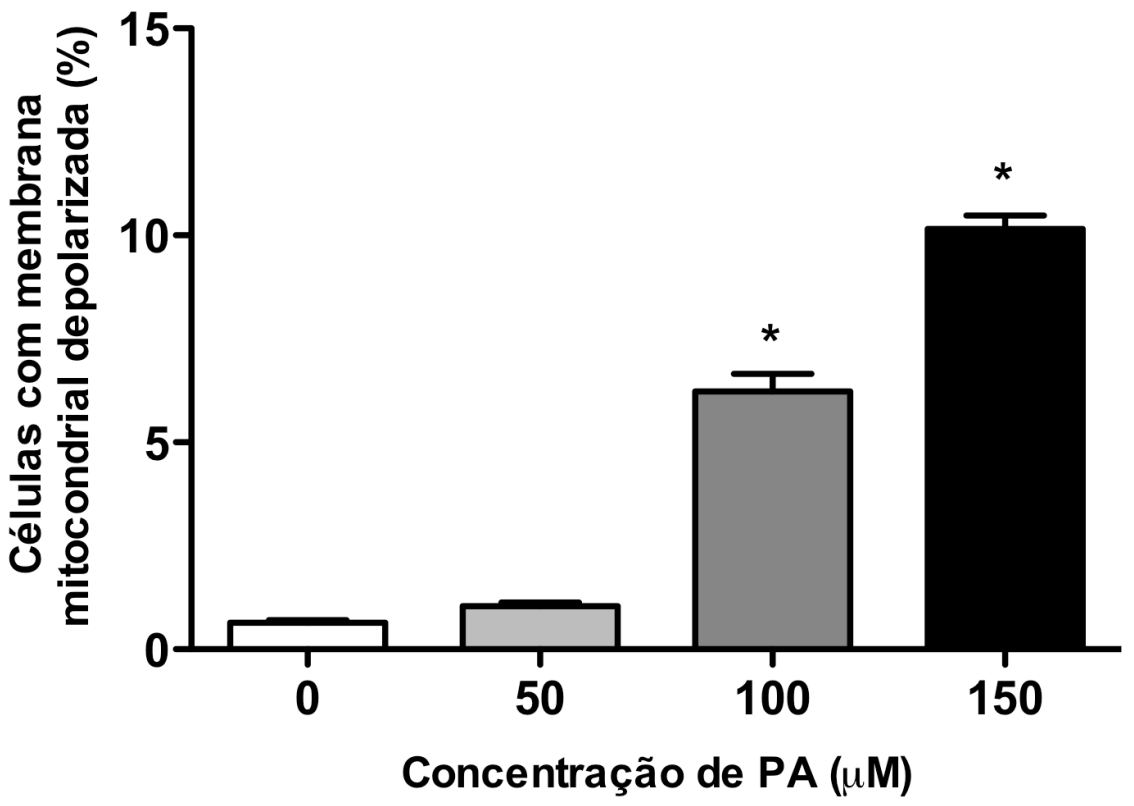

Figura 7 - Avaliação do efeito de PA sobre a despolarização da membrana mitocondrial de células Jurkat. Análise por citometria de fluxo da despolarização da membrana mitocondrial de células Jurkat incubadas com PA por 24h. Resultados estão expressos como média \pm E.P.M de $n=3$ ensaios. * $p<0,05$ quando comparados ao controle. 


\subsubsection{Liberação do citocromo c da mitocôndria}

O citocromo c é uma proteína do grupo heme que está associada à membrana interna da mitocôndria. Em resposta a sinais pró-apoptóticos, há indução da liberação do citocromo c para o citossol possibilitando a ativação de vias de morte celular. A incubação com PA aumentou o conteúdo de citocromo c no citossol e diminuição na mitocôndria de maneira dose dependente (Figura $5)$. 


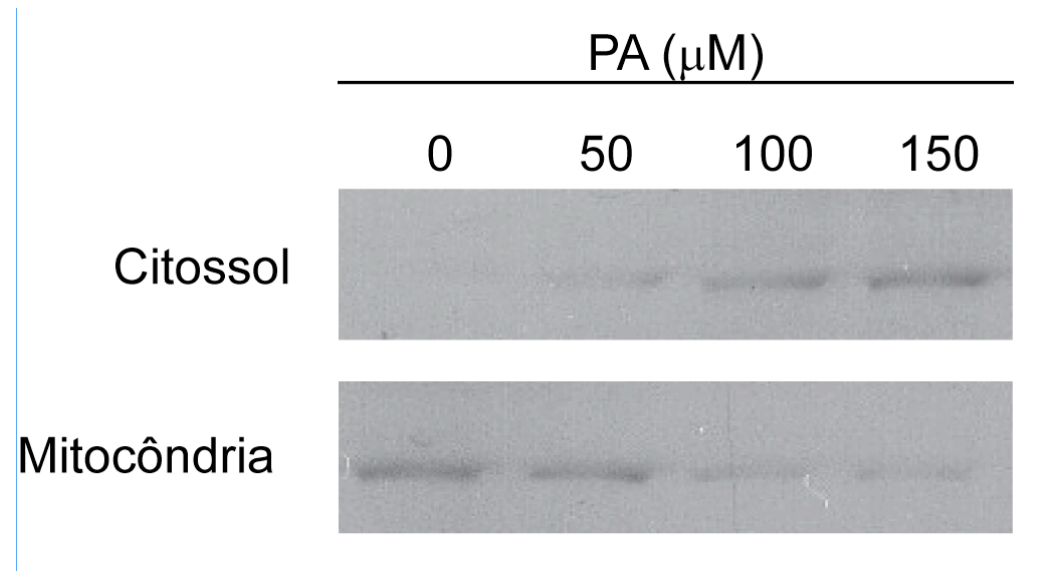

\section{$14 \mathrm{kDa}$}

B
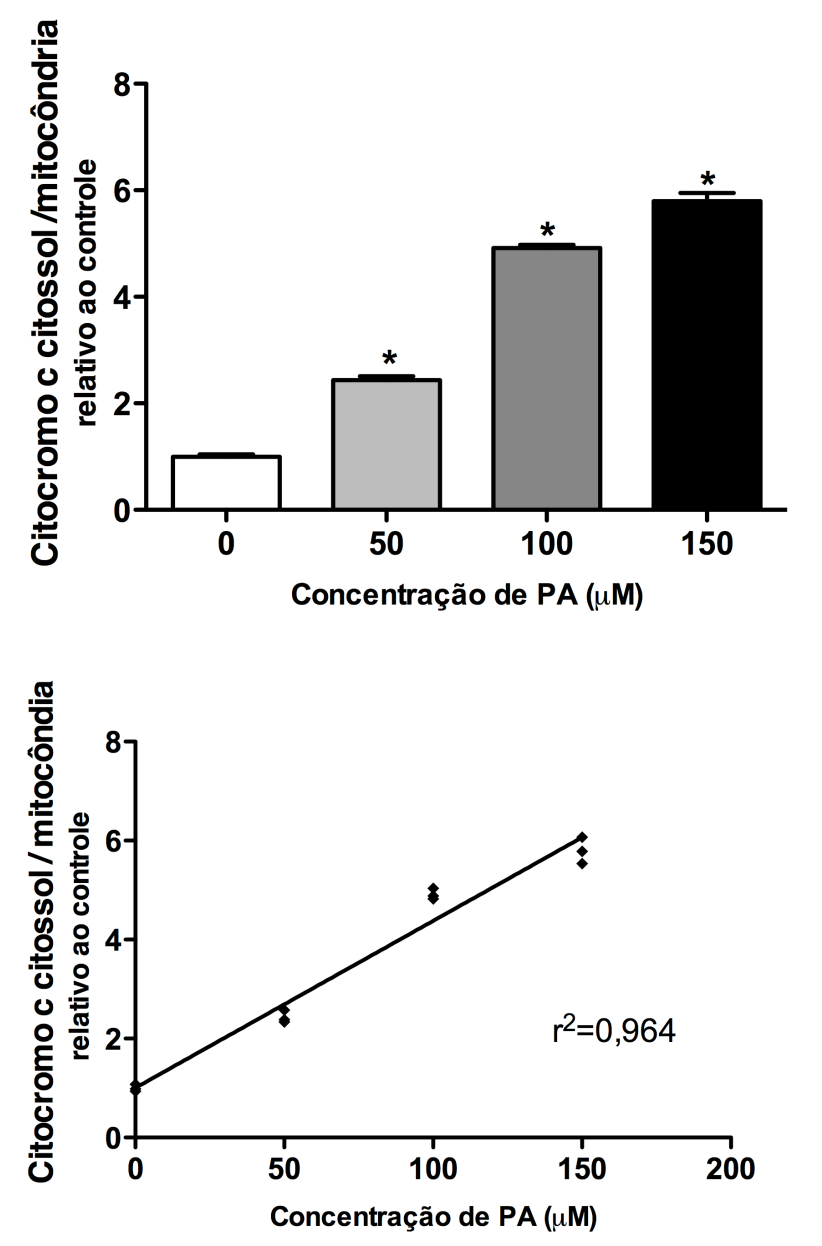

Figura 8 - Sub-fracionamento celular de células incubadas com diferentes concentrações de PA. (A) A análise do citocromo c foi realizada por western blotting. Amostras de mesma quantidade de proteínas foram submetidas à separação protéica por eletroforese em gel de poliacrilamida. (B) O citocromo c liberado para o citossol e da fração mitocondrial foi quantificado por densidade óptica e apresentado como razão citossol/mitondria. Os resultados estão expressos como média \pm E.P.M de $n=3$ ensaios. ${ }^{*} p<0,001$ e ${ }^{*} p<0,0001$ quando comparado ao controle. 


\subsubsection{Avaliação da ativação das caspases 3 e 9}

As caspases são responsáveis pelo desencadeamento do processo apoptótico. A ativação das caspases 3 e 9 sugere que o processo apoptótico foi disparado pela via intrínseca. A ativação dessas caspases é mostrada a partir da formação de produtos de clivagem. A caspase 3 é uma proteína de 35 kD que é clivada gerando produtos de 17 e 19 kD. A caspase 9 possui 47 kD de peso molecular e quando ativada gera um produto de clivagem de $37 \mathrm{kD}$. A análise por western blotting indica que as caspases 3 e 9 levam à geração de formas ativas de maneira dependente da concentração de PA. 


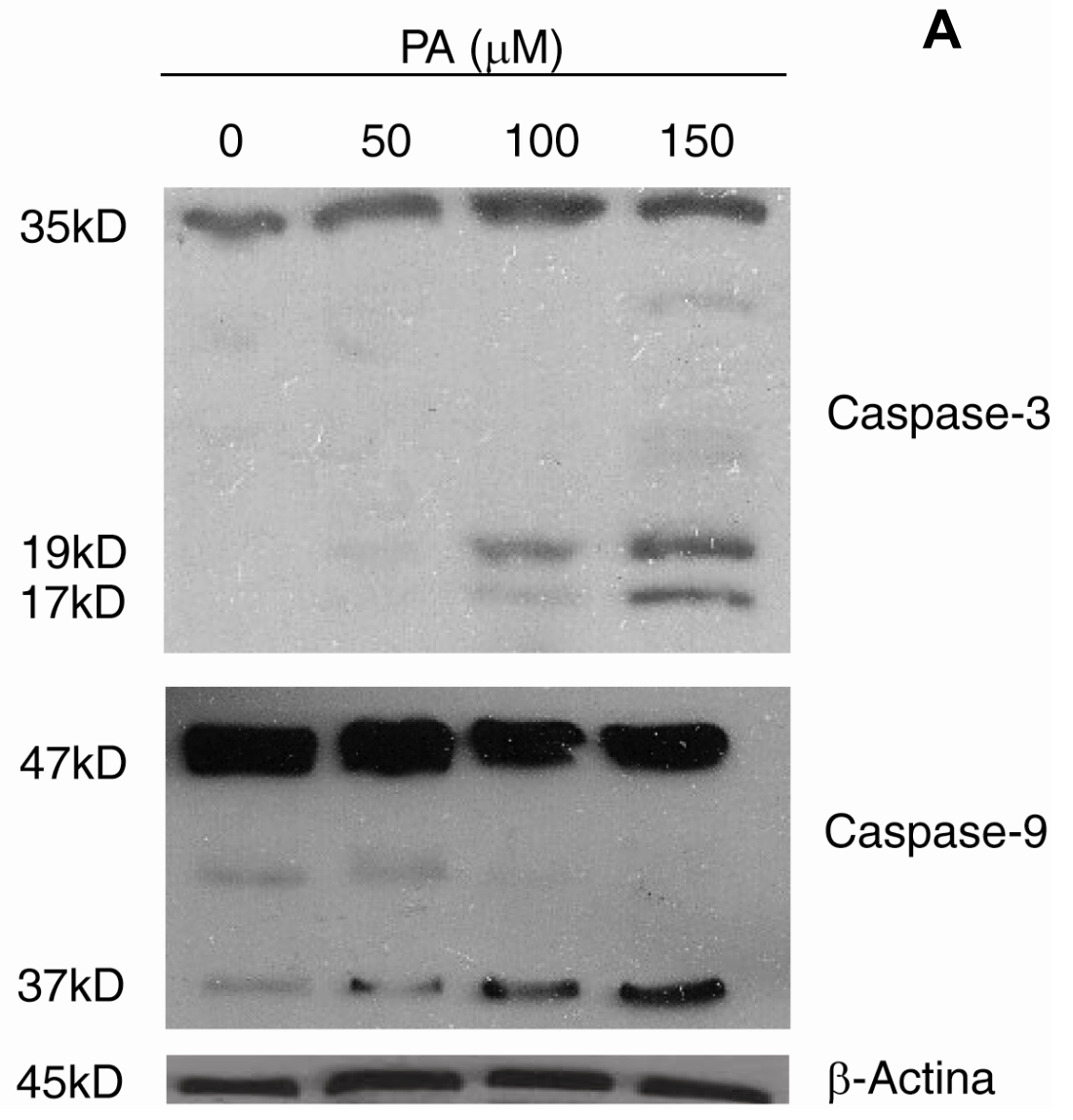

B
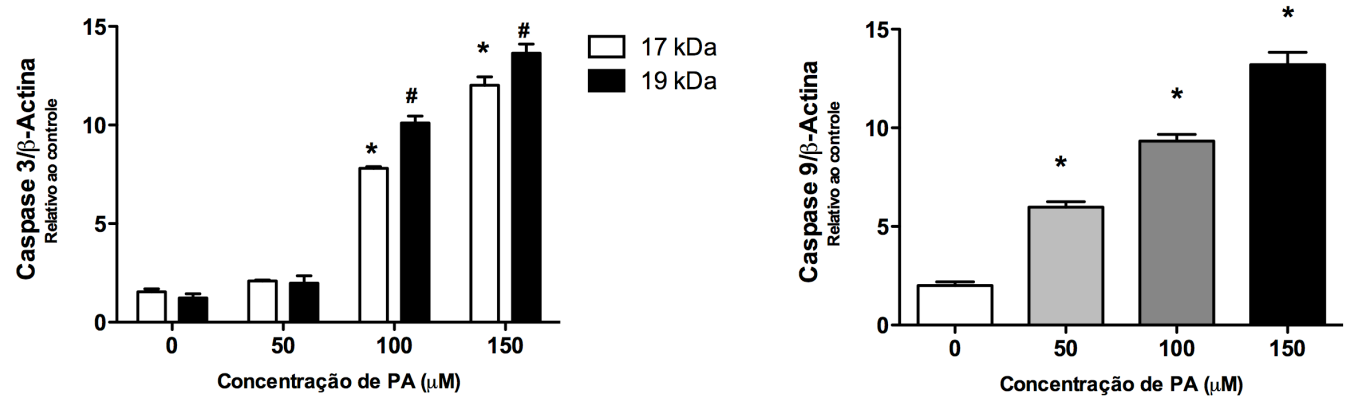

Figura 6 - Avaliação da atividade das caspases 3 e 9 de células Jurkat tratadas com PA (50, 100 e $150 \mu M$ ) por $24 h$. (A) Amostras com mesma quantidade de proteínas foram analisadas por western blotting após separação protéica por eletroforese em gel de poliacrilamida. A análise indica a ativação da caspase 3 pela sua clivagem e o surgimento das sub-unidades de 17 e $19 \mathrm{kDa}$. Para a ativação da caspase 9 há a clivagem desta e o surgimento da sub-unidade de $37 \mathrm{kDa}$. (B e C) Quantificação por densidade óptica da sub-unidades 17 e 19 kDa da caspase 3 e da sub-unidade de $37 \mathrm{kDa}$ da caspase 9 . Os resultados estão expressos como média \pm E.P.M de $n=3$ ensaios. ${ }^{*} p<0,05$ quando comparado ao controle $(17 \mathrm{kDa}) \mathrm{e}^{*} \mathrm{p}<0,05$ quando comparado ao controle (19 kDa). 


\subsubsection{Avaliação da ativação de PKC-ठ}

A PKC é uma superfamília de proteína quinase de serina e treonina. Estas proteínas fosforilam um grande número de proteínas alvo que participam em diversas vias de sinalização como a da insulina. A PKC-ס é uma isoforma e sua ativação está ligada ao processo de apoptose. O tratamento com PA mostra que a PKC- $\delta$ foi ativada de forma dose-dependente à concentração do ácido graxo.

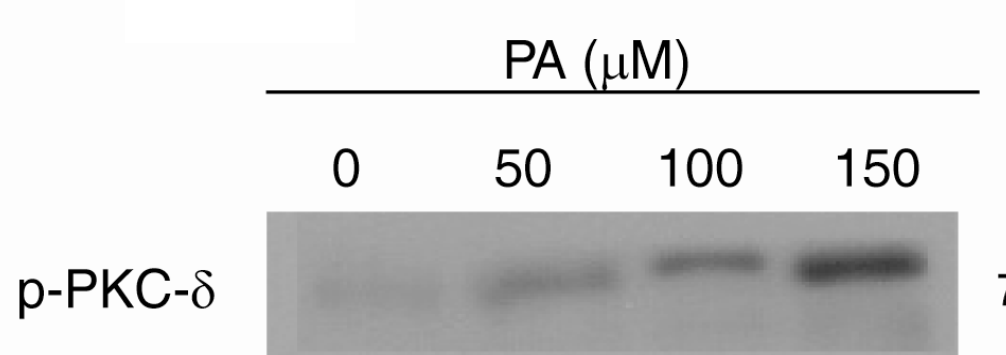

A

$77 \mathrm{kDa}$

Actina

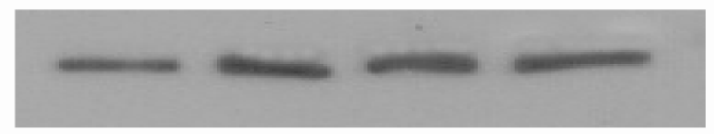

$43 \mathrm{kDa}$

B

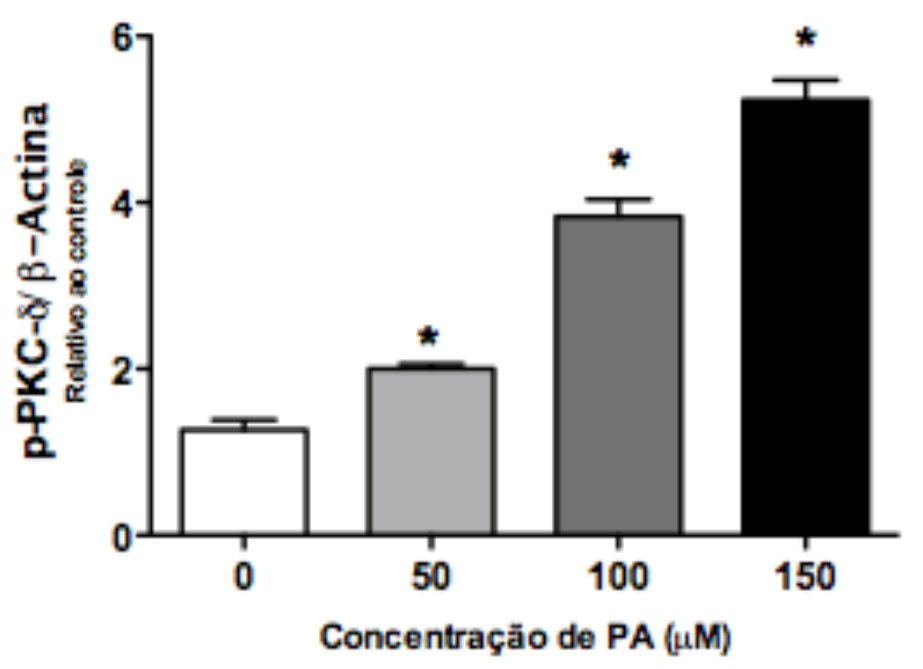

Figura 7 - Avaliação da atividade da PKC-ס de células Jurkat tratadas com PA (50, 100 e $150 \mu M)$ por $24 \boldsymbol{h}$. (A) Amostras com mesma quantidade de proteínas foram analisadas por western blotting após separação protéica por eletroforese em gel de poliacrilamida. (B) Quantificação do conteúdo de $p-P K C-\delta$. Resultados mostrados como média \pm E.P.Mde $n=3$ ensaios. * $p<$ $0,001 \mathrm{e}^{\#} \mathrm{p}<0,0001$ quando comparado ao controle. 


\subsubsection{Efeito do PA sobre a via de sinalização das MAPK na morte das células Jurkat}

A MAPK é uma superfamília de proteínas quinases que respondem a estímulos extra-celulares como por exemplo mitógenos, estresse osmótico e citocinas pró-inflamatórias. As MAPK regulam processos celulares como mitose, diferenciação celular, proliferação e apoptose. Dentre os grupos das MAPK destaca-se as ERK, que respondem a fatores de crescimento e regulam os processos de diferenciação e proliferação celular; e as p38 e as JNK, que respondem a estímulos estressantes (citocinas, irradiação UV e ROS, por exemplo) e estão envolvidas na diferenciação celular e apoptose (CHANG e KARIN, 2001; WESTON;LAMBRIGHT;DAVIS, 2002).

As proteínas quinases, JNK, p38 MAPK e ERK, foram analisadas por western blotting após tratamento das células Jurkat com PA. O PA induziu fosforilação de JNK, enquanto que a quantidade total de JNK não foi alterada. A fosforilação da p38 MAPK também apresenta-se aumentada pelo tratamento com PA. A ERK também teve aumento significativo da sua forma fosforilada pelo tratamento com PA. 


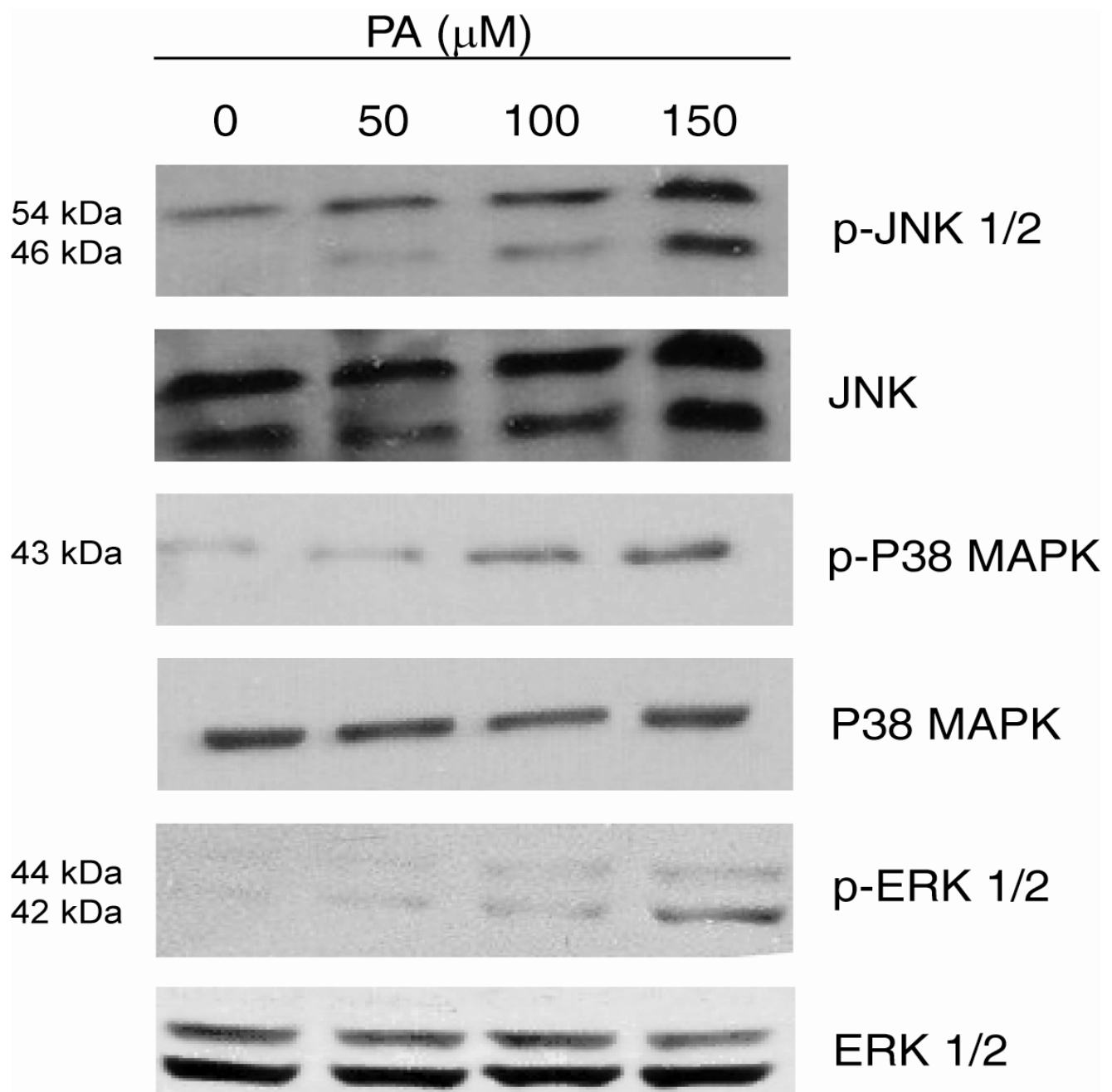

Figura 8 - Análise da ativação das MAPK por PA. Avaliação do grau de fosforilação das quinases JNK, p38 MAPK e ERK de células Jurkat tratadas com PA (50, 100 e $150 \mu \mathrm{M})$ por 24h. Amostras com a mesma quantidade de proteínas foram analisadas por western blotting após separação protéica por eletroforese em gel de poliacrilamida. 


\subsection{AVALIAÇÃO DO EFEITO DO PA SOBRE O ESTRESSE OXIDATIVO}

\subsubsection{Efeito do tratamento com PA na produção de superóxido em células}

Jurkat

A incubação de células Jurkat com PA induziu a formação de espécies reativas de oxigênio como o superóxido, determinadas pela marcação desta com o fluoróforo diidroetidina e analisadas em citometria de fluxo (Figura 9A). Observa-se que a concentração de superóxido está diretamente relacionada com a concentração de PA utilizada.

A

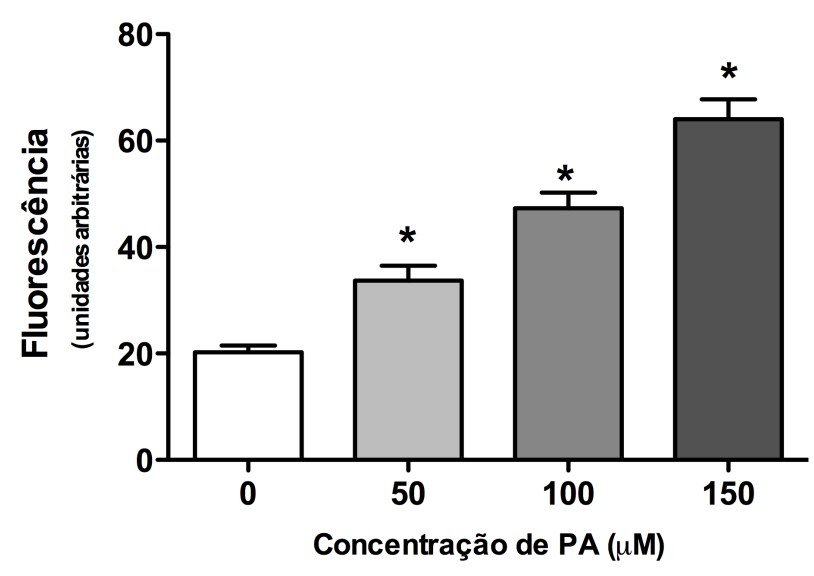

B

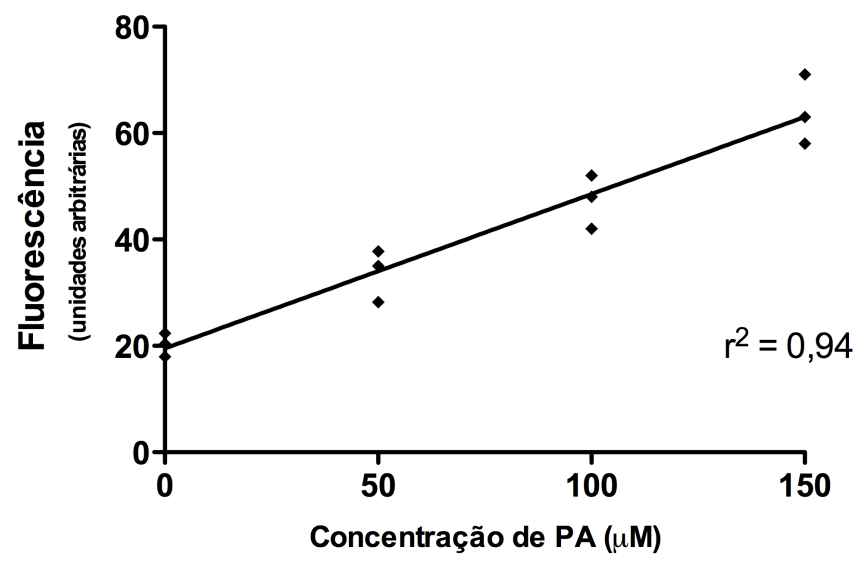

Figura 9 - Efeito do tratamento de PA sobre a produção de superóxido em células Jurkat. (A) Análise da detecção de ROS por citometria de fluxo após incubação de células Jurkat com $\mathrm{PA}(50,100$ e $150 \mu \mathrm{M})$ por 24 h. Resultados estão expressos como média \pm E.P.M de $n=3$ ensaios. ${ }^{*} p<0,001$ quando comparado ao controle. (B) Correlação entre a concentração de PA e a produção de ROS em células Jurkat $\left(r^{2}=0,94\right)$. 


\subsubsection{Efeito do PA sobre a produção de peróxido de hidrogênio em células}

Jurkat

Para a detecção da produção de peróxido de hidrogênio nas células tratadas com PA foi utilizado o corante Amplex Red. Observa-se que a produção de peróxido de hidrogênio está relacionada de maneira dosedependente com a concentração de PA.

A

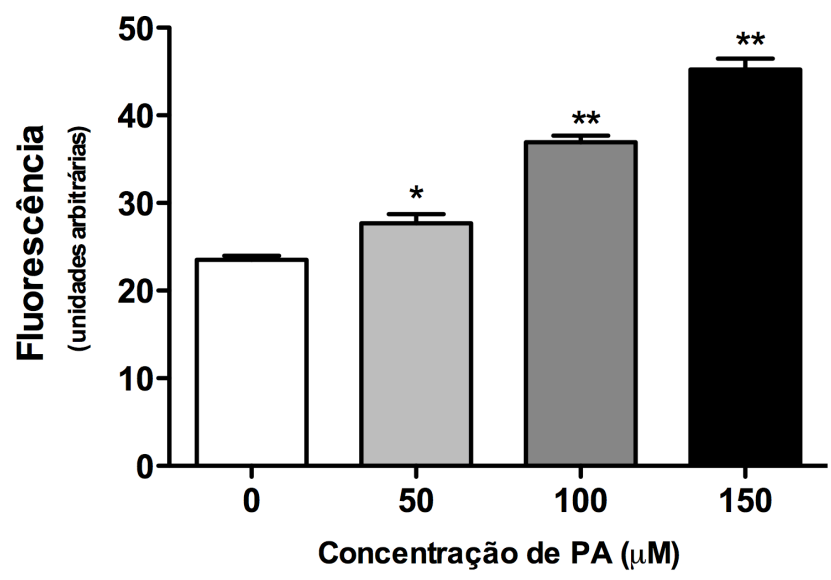

B

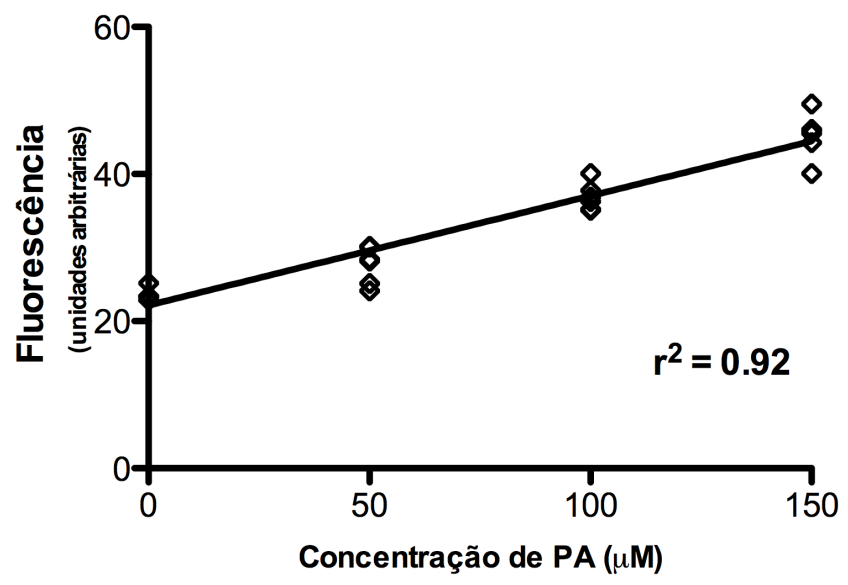

Figura 10 - Efeito do tratamento de PA sobre a produção de peróxido de hidrogênio em células Jurkat. (A) Avaliação da produção de peróxido de hidrogênio em células Jurkat tratadas com PA $(50,100$ e $150 \mu \mathrm{M})$ por $24 \mathrm{~h}$ pelo método do Amplex Red. Resultados estão expressos como média \pm E.P.M de $n=6$ ensaios. * $p<0,05$ e ** $p<0,001$ quando comparado ao controle. (B) Correlação entre a concentração de PA e a fluorescência do ensaio de produção de peróxido de hidrogênio de células Jurkat $\left(r^{2}=0,92\right)$. 


\subsubsection{Efeito do PA sobre a produção de nitrito em células Jurkat}

O óxido nítrico é um importante mensageiro intracelular modulando o fluxo sangüíneo, trombose e a atividade neural. No entanto, a sua produção em excesso pode ser tóxica às células pois em ambientes oxidativos pode reagir com superóxido produzindo peroxinitrito, um potente oxidante.

A produção de $\mathrm{NO}$ foi quantificada indiretamente à partir da dosagem de nitrito , um produto de oxidação mais estável. O nitrito foi quantificado no meio de incubação através do método de Griess. O tratamento com PA causou aumento significativo na produção de nitrito à partir de $100 \mu \mathrm{M}$.

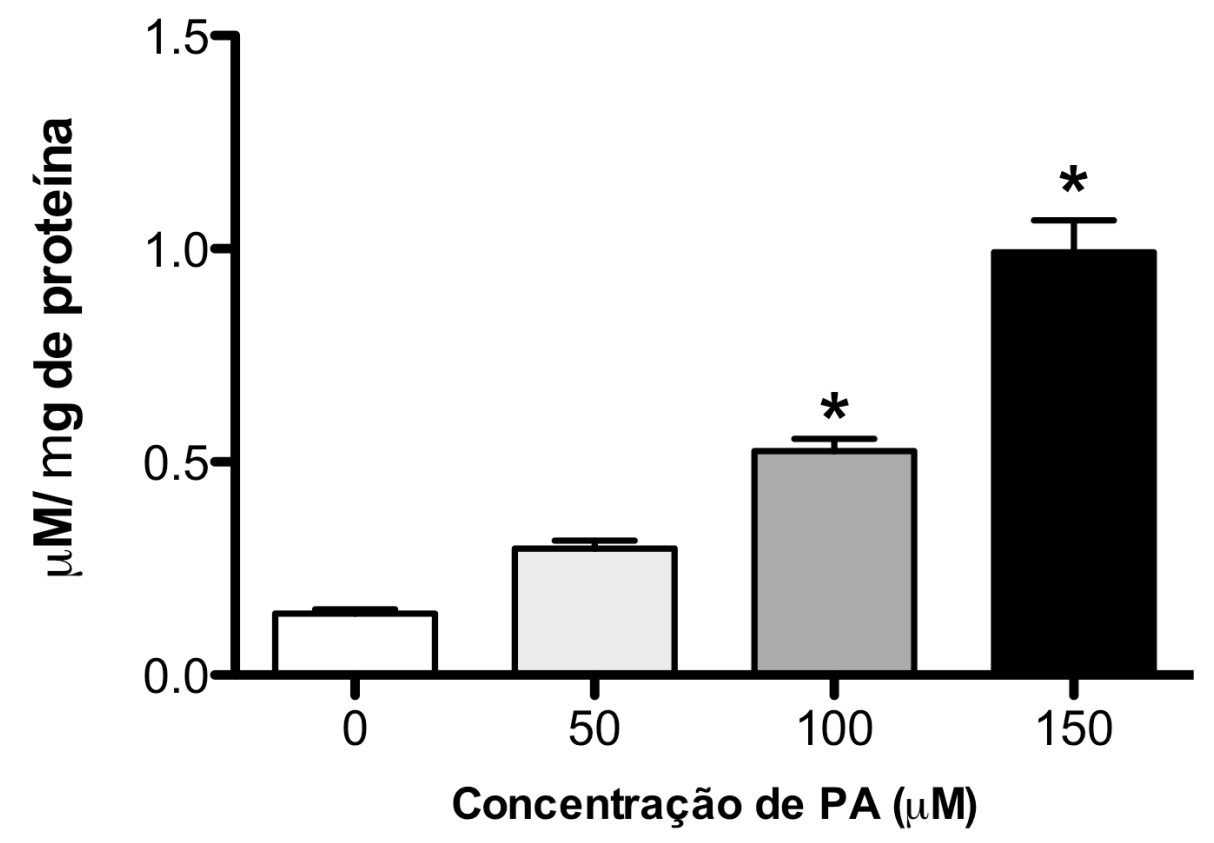

Figura 11 - Efeito do tratamento de PA sobre a produção de nitrito em células Jurkat Avaliação da produção de nitrito em células Jurkat tratadas com PA $(50,100$ e $150 \mu \mathrm{M})$ por $24 \mathrm{~h}$ pelo método de Griess. * $\mathrm{p}<0,001$ Resultados estão expressos como média \pm E.P.M de $n=5$ ensaios. 


\subsubsection{Efeito do PA sobre a expressão da proteína iNOS}

A proteína óxido nítrico sintetase induzível (iNOS) produz do NO na célula sendo ativada por fatores transcricionais como o NF-KB. O tratamento com PA induziu aumento significativo na expressão da iNOS à partir de $100 \mu \mathrm{M}$
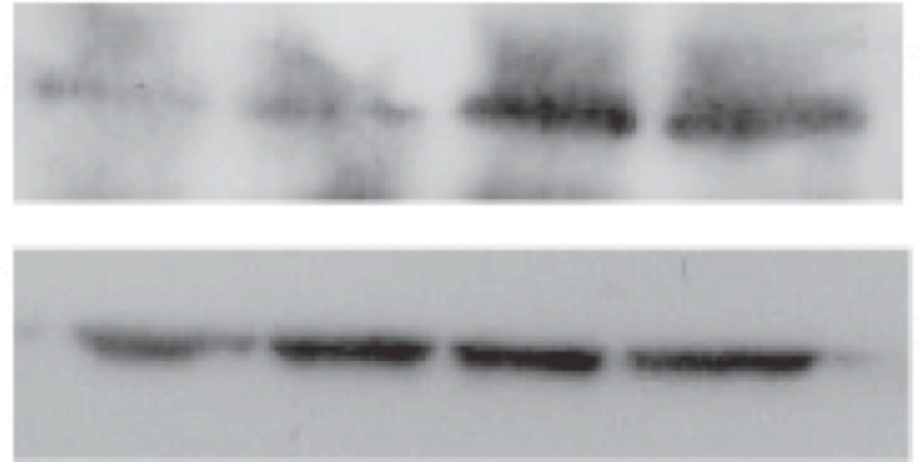

\section{$36 \mathrm{KDa}$}

Figura 12 - Avaliação da expressão da iNOS de células Jurkat tratadas com PA (50, 100 e $150 \mu M)$ por $24 h$. (A) Amostras com mesma quantidade de proteínas foram analisadas por western blotting após separação protéica por eletroforese em gel de poliacrilamida. (B) Quantificação do conteúdo de iNOS. Resultados mostrados como média \pm E.P.M de $n=3$ ensaios. * $\mathrm{p}<$ 0,001 e ${ }^{\#}<0,0001$ quando comparado ao controle. 


\subsubsection{Quantificação de GSH e GSSG}

A glutationa é o antioxidante mais importante produzido pelas células; $90 \%$ encontra-se na sua forma reduzida (GSH) e $10 \%$ na forma oxidada (GSSG). A GSH participa diretamente na neutralização de radicais livres e ROS doando um elétron para as moléculas instáveis. A GSH torna-se reativa e reage com outra molécula reativa de GSH formando GSSG, que pode ser regenerada a sua forma reduzida pela enzima glutationa redutase. A razão GSH/GSSG pode ser utilizado como um marcador de estresse oxidativo e de toxicidade celular (PASTORE et al., 2003).

O tratamento das células Jurkat com PA exibiu uma diminuição do conteúdo de GSH e aumento de GSSG. A razão GSG/GSSG mostrou-se diminuída de forma dose dependente à concentração de PA. 


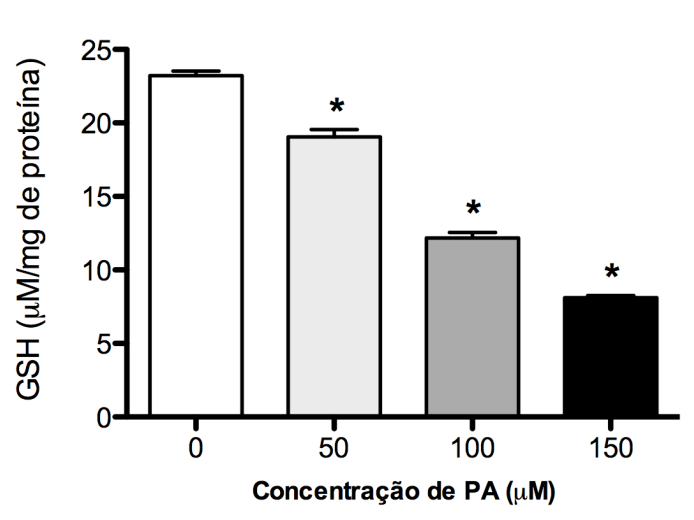

A

B

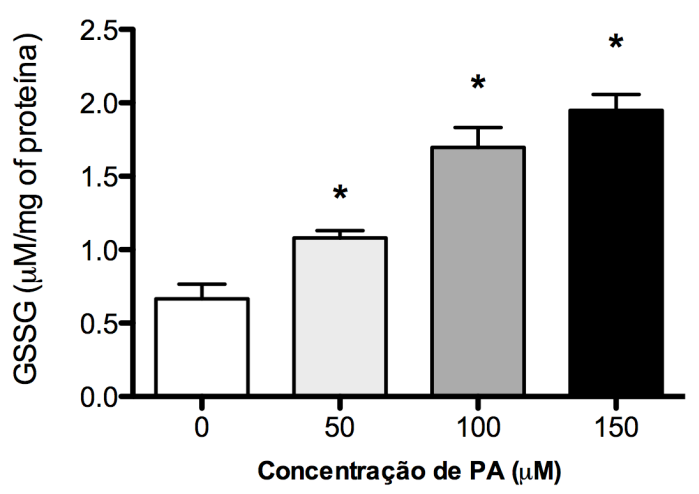

C

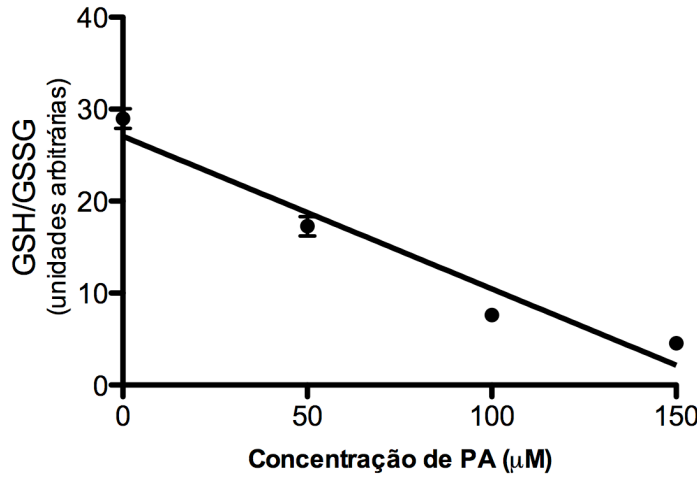

Figura 13 - Efeito do tratamento de PA sobre concentração intracelular de GSH e de GSSG em células Jurkat. Quantificação de GSG (A) e GSSG (B) intracelular em células Jurkat tratadas com PA (50, 100 ou $150 \mu \mathrm{M})$ por 24 h.. Resultados estão expressos como média \pm E.P.M de $n=5$ ensaios. * $p<0,001$ quando comparado ao controle. C Expressão da razão GSH/GSSG 


\subsection{AVALIAÇÃO SOBRE O PERFIL LIPÍDICO}

\subsubsection{Avaliação morfológica de células Jurkat tratadas com PA}

O tratamento com PA levou a formação de gotículas de lipídeos no interior das células Jurkat, identificadas após coloração por May-Grunwald-Giemsa como observado na Figura 15B.

A

B
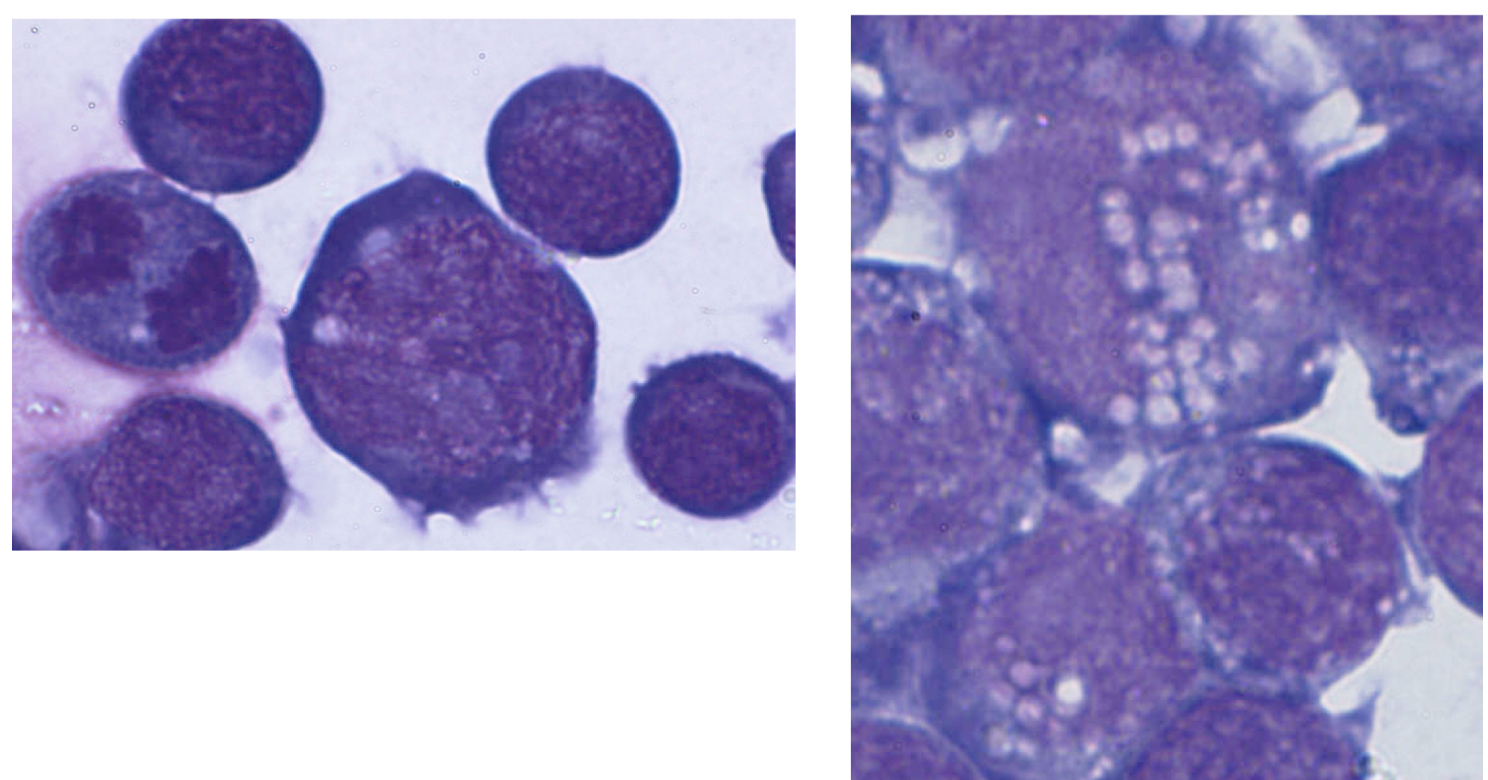

Figura 15 - Análise morfológica das alterações nucleares e citoplasmáticas através da coloração por May-Grunwald-Giemsa sobre o efeito do tratamento de PA em células Jurkat. (A) Células controles; (B) Células tratadas com $50 \mu \mathrm{M}$ de PA por 24 horas. 


\subsubsection{Avaliação do conteúdo de lípides neutros em células Jurkat tratadas}

com PA

As células Jurkat incubadas com PA mostraram aumento no conteúdo intracelular de triacilgliceróis confirmado pela marcação com o corante Oil Red (Figuras 16A e B). A mesma característica foi observada no ensaio de marcação dos lípides neutros utilizando o corante fluorescente Nile Red e analisado por citometria de fluxo. Observa-se que a concentração de lípides neutros (basicamente triacilgliceróis) é diretamente influenciada pela concentração de PA utilizada no tratamento de forma dose dependente (Figura 17).
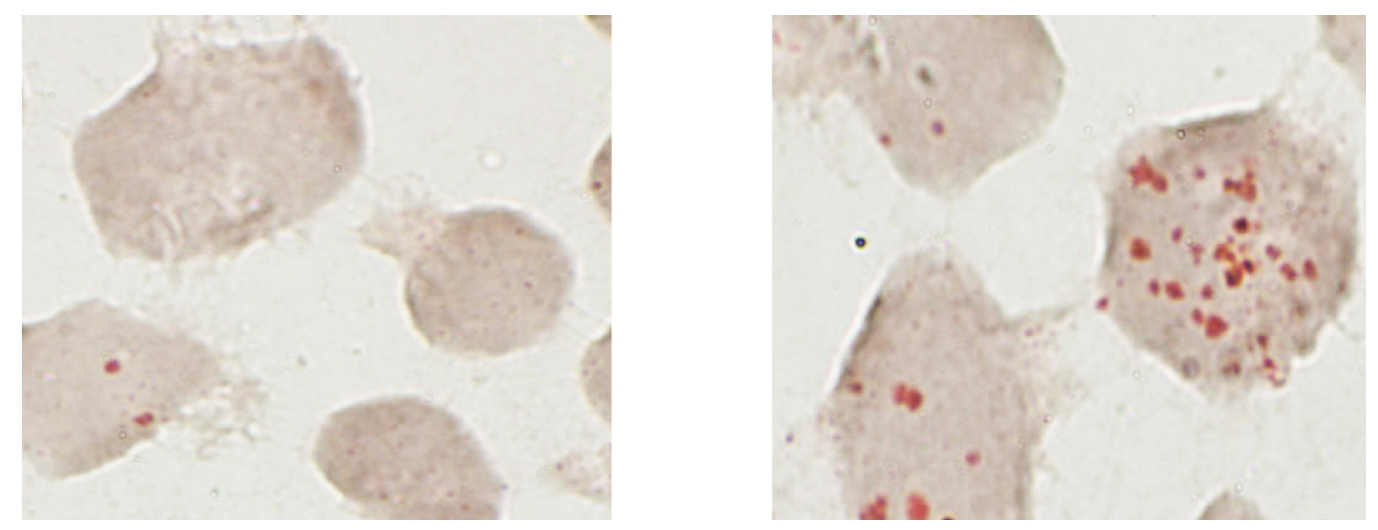

Figura 16 - Efeito do tratamento de PA sobre concentração intracelular de triacilgliceróis em células Jurkat através da marcação com Oil Red. (A) Controle, (B) Células tratadas com PA $50 \mu \mathrm{M}$ por $24 \mathrm{~h}$. 


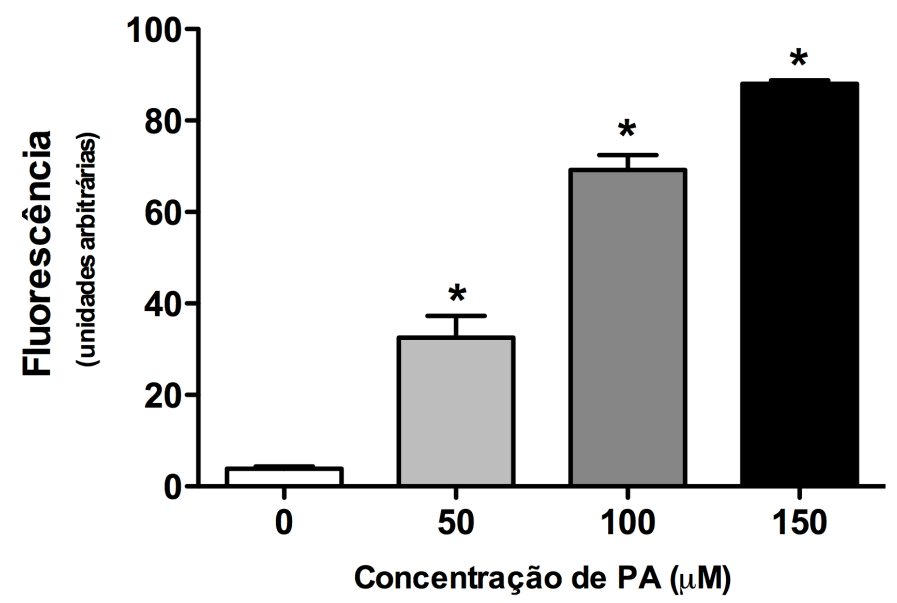

B

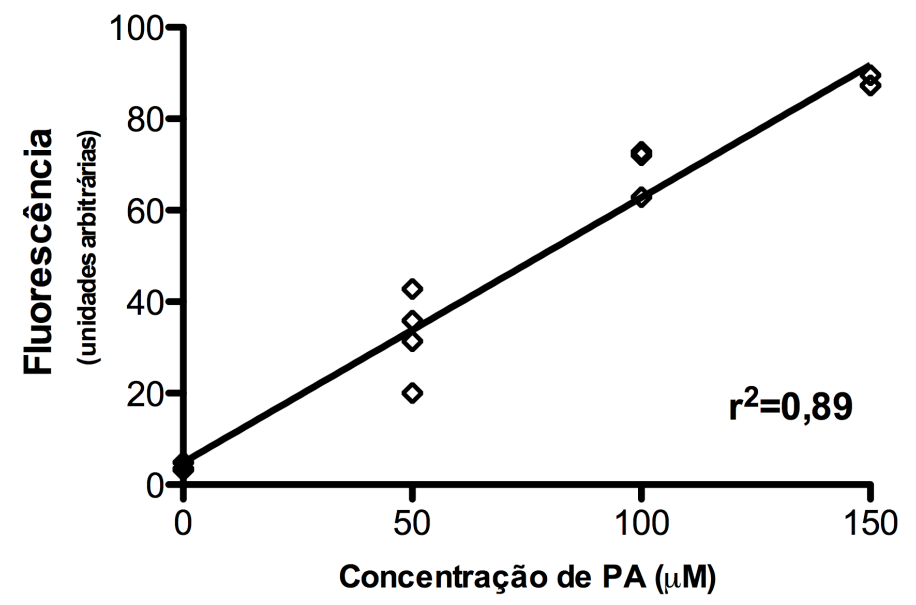

Figura 17 - Efeito do tratamento de PA sobre a concentração de lípides neutros em células Jurkat (A) Marcação de lípides neutros com Nile Red em células tratadas com PA (50, 100 ou 150 $\mu \mathrm{M})$ por $24 \mathrm{~h}$ e analisadas em citometria de fluxo. Resultados estão expressos como média \pm E.P.M de $n=5$ ensaios. ${ }^{*} p<0,001$ quando comparado ao controle. (B) Correlação entre a concentração de PA e a fluorescência de Nile Red em células Jurkat $\left(r^{2}=0,89\right)$. 


\subsubsection{Incorporação do PA nas frações de lipídios intracelular}

Para a análise da incorporação do PA em frações lipídicas, as células Jurkat foram submetidas ao tratamento na presença de $\left[{ }^{14} \mathrm{C}\right]$-palmitato. Após 24 horas de tratamento, os lípides foram extraídos e submetidos a uma separação por cromatografia em camada delgada (Figura 18). Após a identificação das bandas correspondentes (triacilgliceróis, ésteres de colesterol, fosfolipídeos e ácidos graxos livres) estas foram raspadas da placa e a radioatividade do $\left[{ }^{14} \mathrm{C}\right]$-palmitato adicionado foi quantificada. O PA aumentou de maneira dose dependente o conteúdo celular de triacilgliceróis, ácidos graxos e fosfolípides. O conteúdo de éster de colesterol teve aumento significativo apenas quando comparado ao controle nas células incubadas com $150 \mu \mathrm{M}$ de PA.

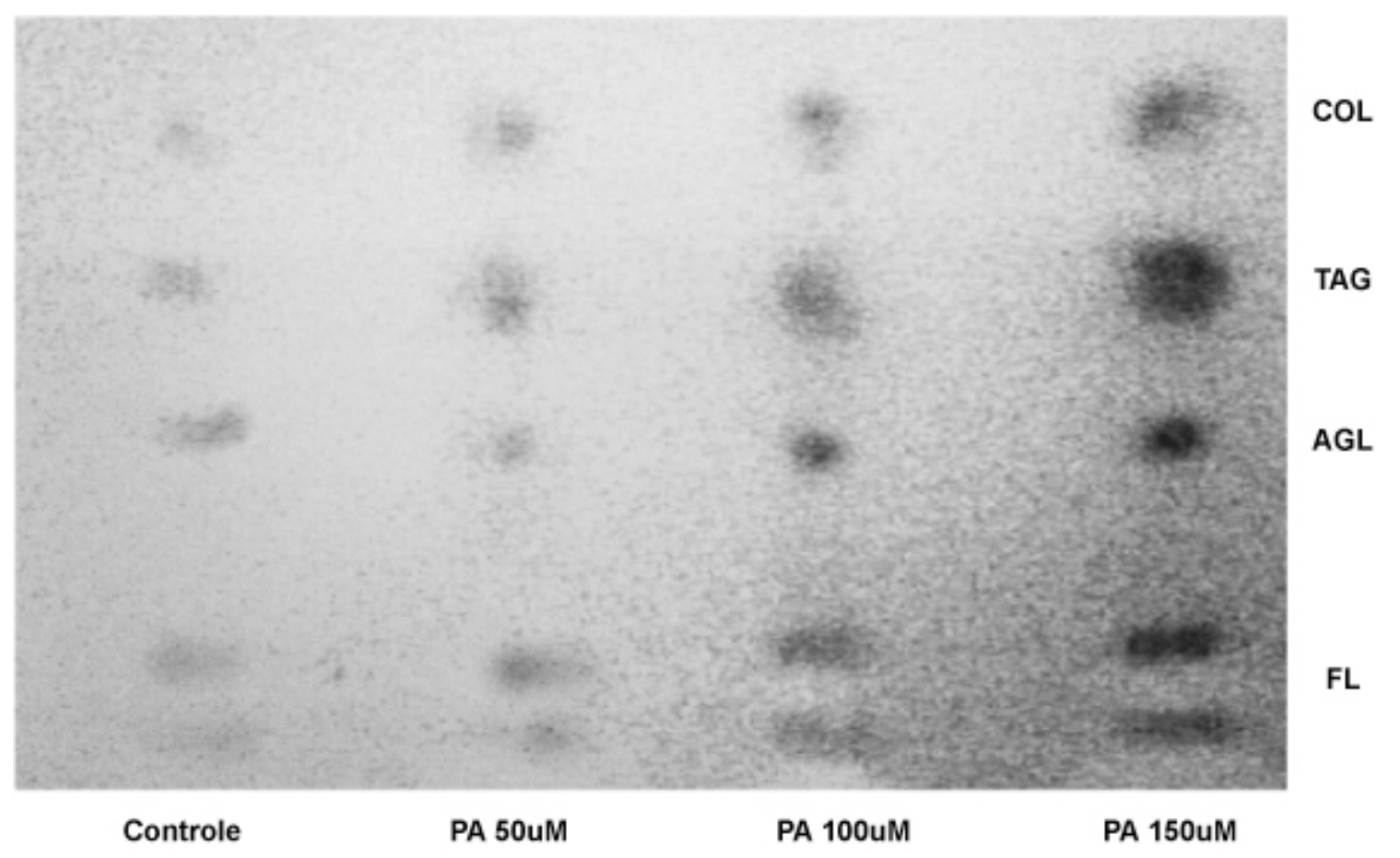

Figura 18 - Avaliação das frações lipídicas de células Jurkat tratadas com PA (50, 100 e $150 \mu M)$ por $24 \mathrm{~h}$. O extrato lipídico das amostras foi separado por cromatografia em camada delgada em

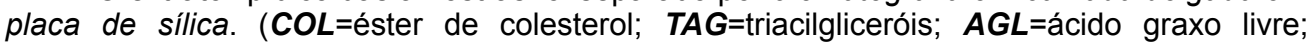
$F L=$ fosfolípides) 

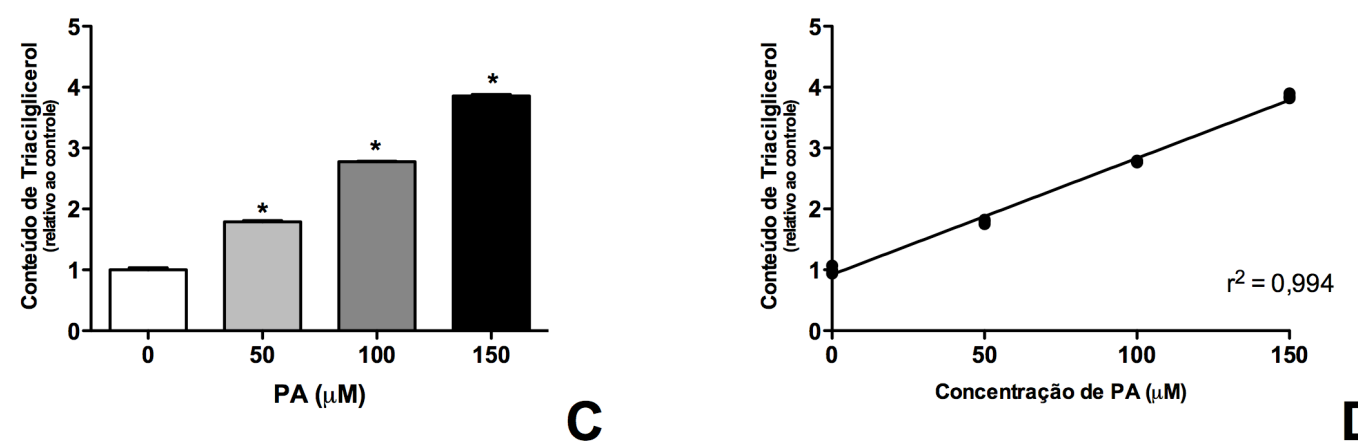

C
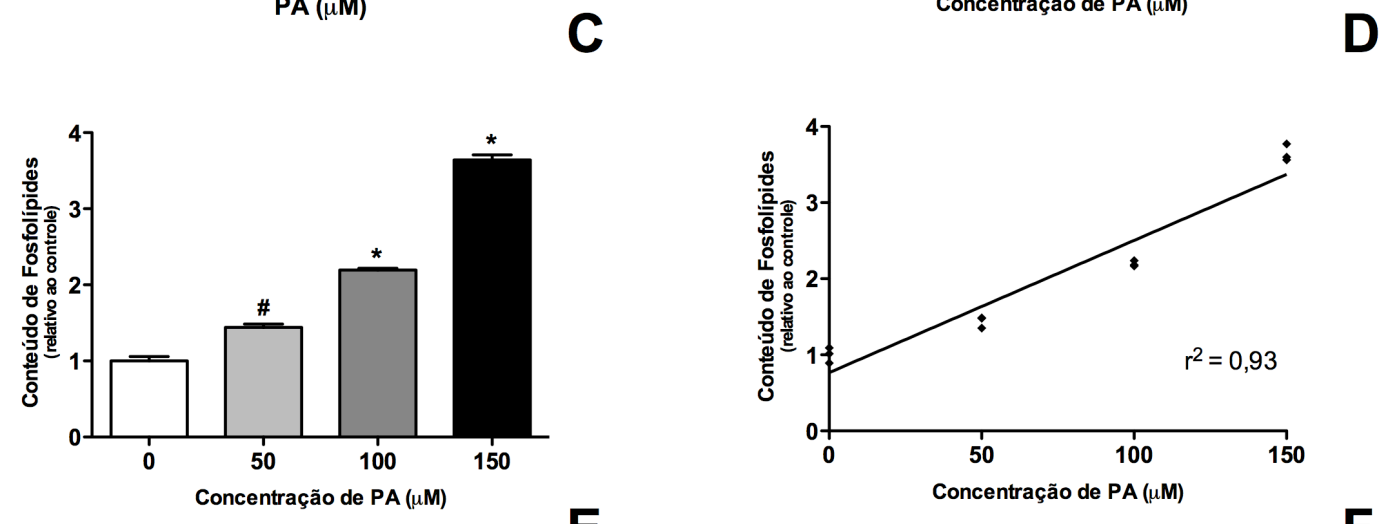

$\mathbf{E}$
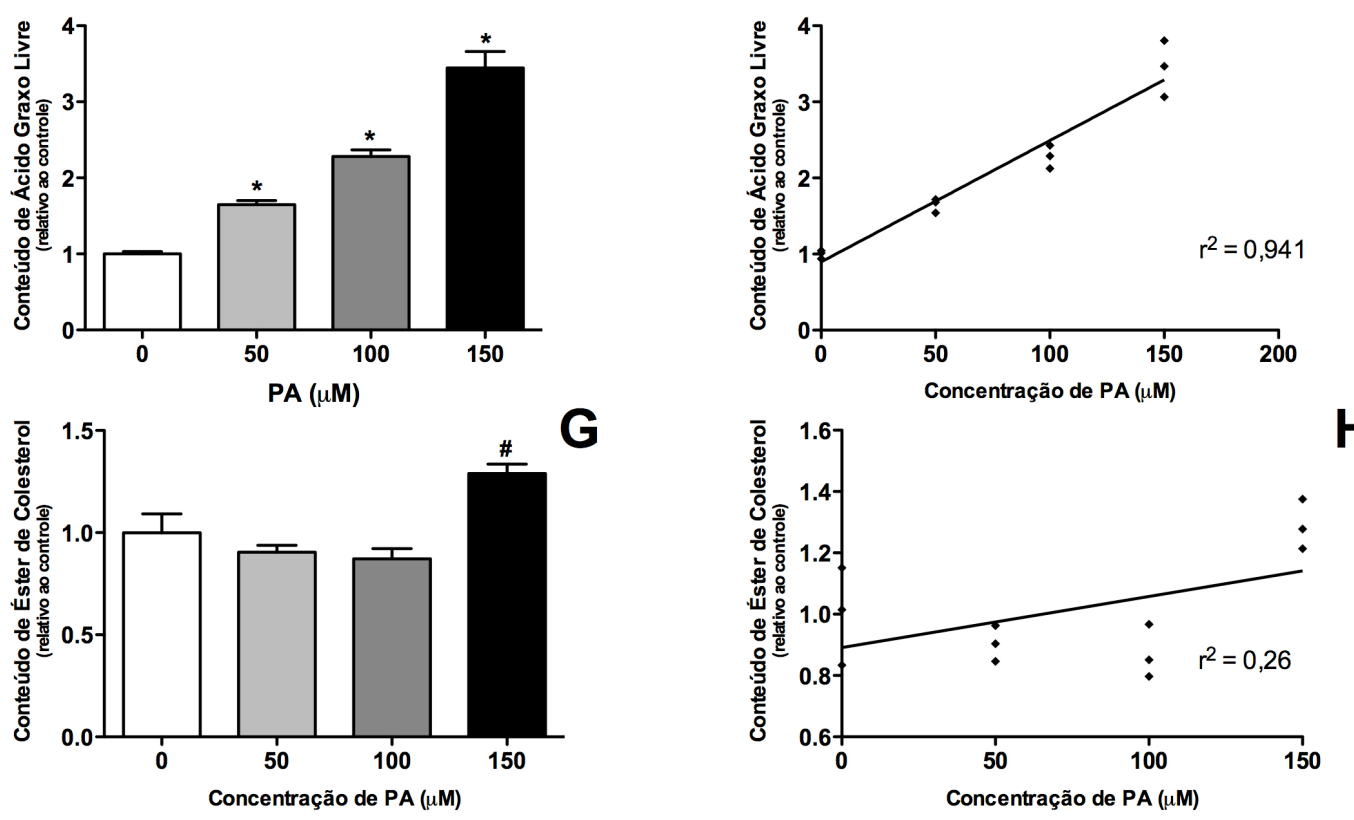

Figura 19 - Análise da incorporação de $\left[{ }^{14} \mathrm{C}\right]$-palmitato em diferentes frações lipídicas após incubação com PA (50,100 e $150 \mu \mathrm{M})$ por $24 \mathrm{~h}$. (A). Triacilgliceróis;(C) Fosfolípides; (E). Ácido graxo livre; (F) Éster de colesterol. Resultados estão expressos como média \pm E.P.M. ${ }^{*} p<0,05$ e ${ }^{\#} p<0,001$ quando comparados ao controle. (B, D, F, H) Correlação entre a concentração de PA e a incorporação de $\left[{ }^{14} \mathrm{C}\right]$-palmitato em diferentes frações lipídicas: 0,$904 ; 0,83 ; 0,841$ e 0,26 , respectivamente. 


\subsubsection{Análise da composição de ácidos graxos em células tratadas com}

PA

A composição de ácidos graxos de células Jurkat foi analisada em HPLC (Figura 20). Os valores em porcentagem de cada ácido graxo estão na Tabela 1. A incubação destas células com PA 50, 100 e $150 \mu \mathrm{M}$ por 24 h elevou a concentração de palmitato em 25\%, 95\% e 277\% em relação ao controle, respectivamente (Figura 21). O tratamento com PA não alterou significativamente a proporção dos outros ácidos graxos analisados.

Tabela 1 - Valores em porcentagem da composição de ácidos graxos nas células Jurkat. As amostras foram analisadas por cromatografia em HPLC. Os valores estão expressos como média \pm E.P.M. de $n=5$ determinações

\begin{tabular}{cc}
\hline Ácido graxo & Porcentagem \\
\hline Láurico (C12:0) & $0,88 \pm 0,17$ \\
Mirístico (C14:0) & $3,78 \pm 0,05$ \\
Palmítico (C16:0) & $29,74 \pm 0,28$ \\
Esteárico (C18:0) & $19,44 \pm 0,8$ \\
Palmitoleico (C16:1) & $3,81 \pm 0,88$ \\
Oleico (C18:1) & $22,42 \pm 0,34$ \\
Linoleico (C18:2) & $7,91 \pm 0,30$ \\
Y-Linolênico (C18:3) & $0,68 \pm 0,33$ \\
Araquidônico (C20:4) & $8,51 \pm 0,39$ \\
Eicosapentaenóico (C20:5) & $1,61 \pm 0,05$ \\
Docosa-hexaenóico (C22:6) & $1,20 \pm 0,21$ \\
\hline
\end{tabular}




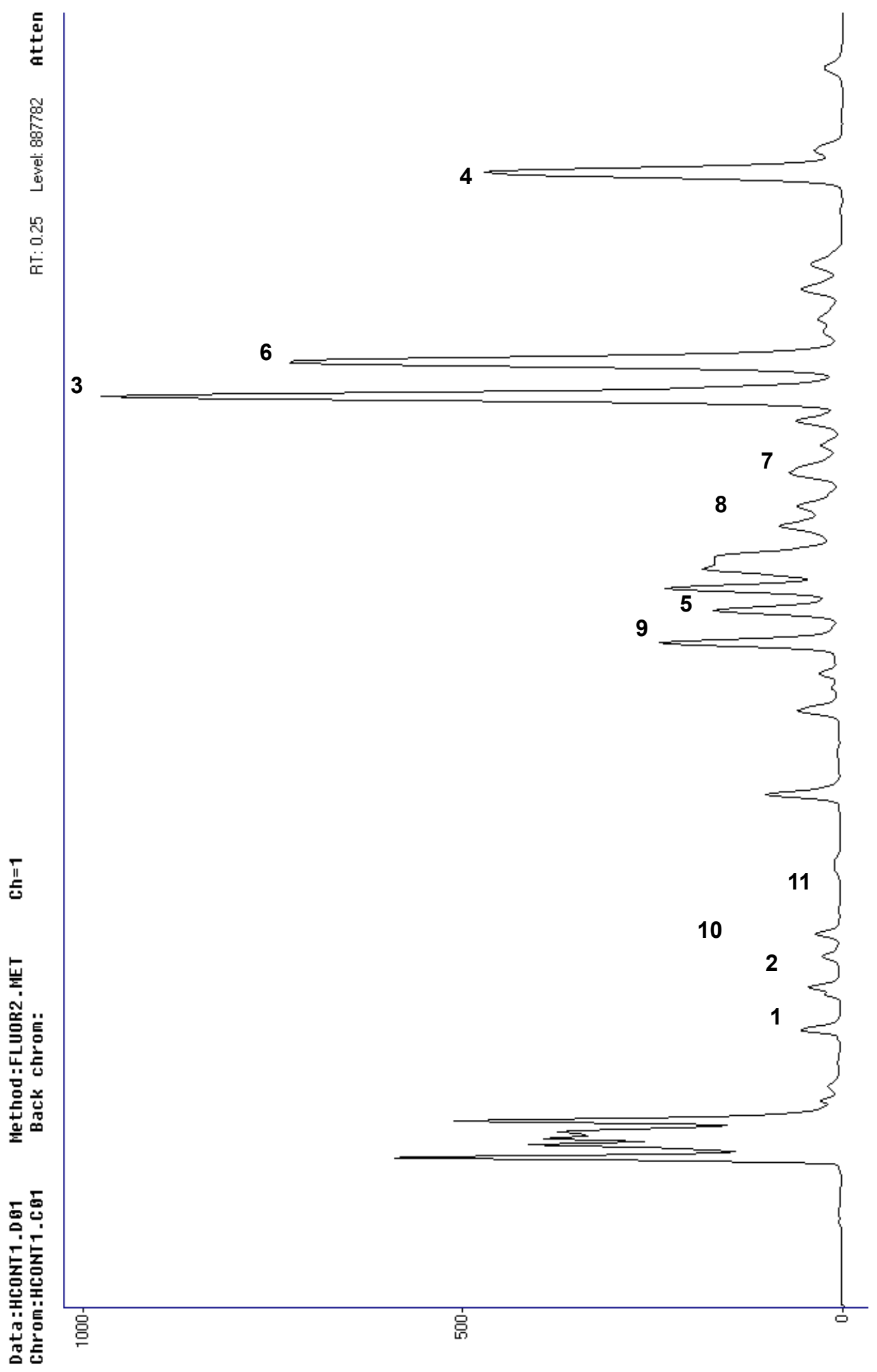

Figura 20 - Análise por HPLC do perfil de ácidos graxos de células Jurkat. 1-láurico, 2-mirístico, 3palmítico, 4-esteárico, 5-palmitoléico, 6-oleico, 7-linoleico, 8-y-linolênico, 9-araquidônico, 10eicosapentaenóico, 11-docosa-hexaenóico. 


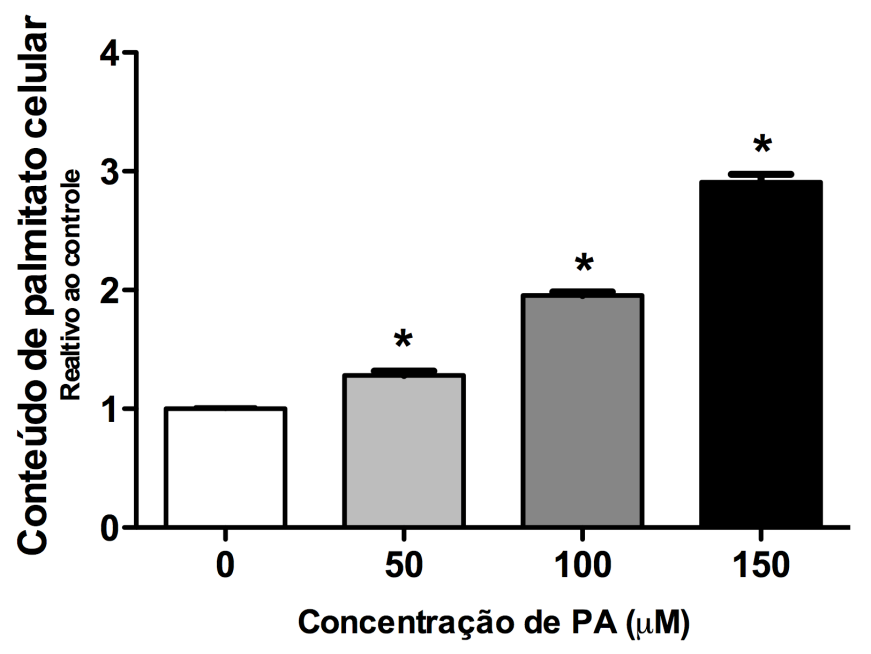

A

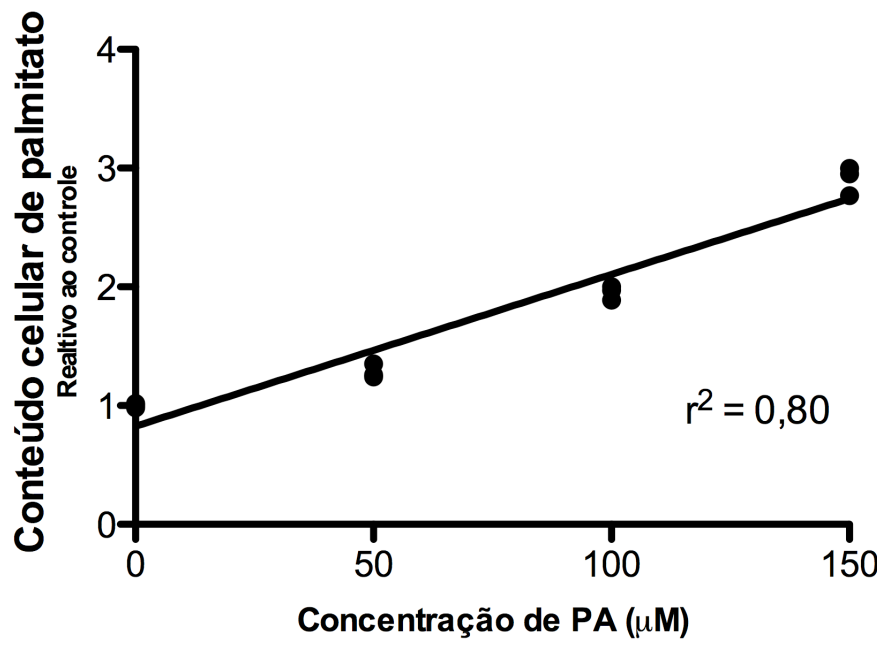

B

Figura 21 - (A) Análise da quantidade de palmitato nas células Jurkat após incubação com PA (50, 100 e $150 \mu \mathrm{M}$ ) por 24h. Resultados estão expressos como média \pm E.P.M. * $p<0,05$ e ${ }^{\#} p<0,001$ quando comparado ao controle. (B) Correlação entre a concentração de PA e o conteúdo celular de palmitato $\left(r^{2}=0,804\right)$. 


\subsection{EFEITO DO PA SOBRE O METABOLISMO DOS LINFÓCITOS}

\subsubsection{Efeito do PA sobre a expressão dos receptores de insulina e de GLUT-4 \\ Em condições basais, os linfócitos apresentam baixa expressão dos}

receptores de insulina (IR) e de GLUT-4, sendo pouco responsíveis à insulina. Análises comparativas da abundância de IR e GLUT-4 foram realizadas em células Jurkat e $\mathrm{J774}$ (linhagem leucêmica de macrófagos de ratos) e os dados estão apresentados na Figura 22. Estas últimas células são responsivas à insulina, assim, foram utilizadas como referência As células foram marcadas com anticorpos anti-IR ou anti-GLUT-4. Em seguida, foram incubados com anticorpo secundário marcado com o fluoróforo FITC (isotiocianato de fluoresceína) e as células foram analisadas por citometria de fluxo. Observa-se que as células Jurkat apresentam baixa expressão de IR e GLUT-4, ao passo que há abundância destas proteínas nas células $\mathrm{J} 774$. 

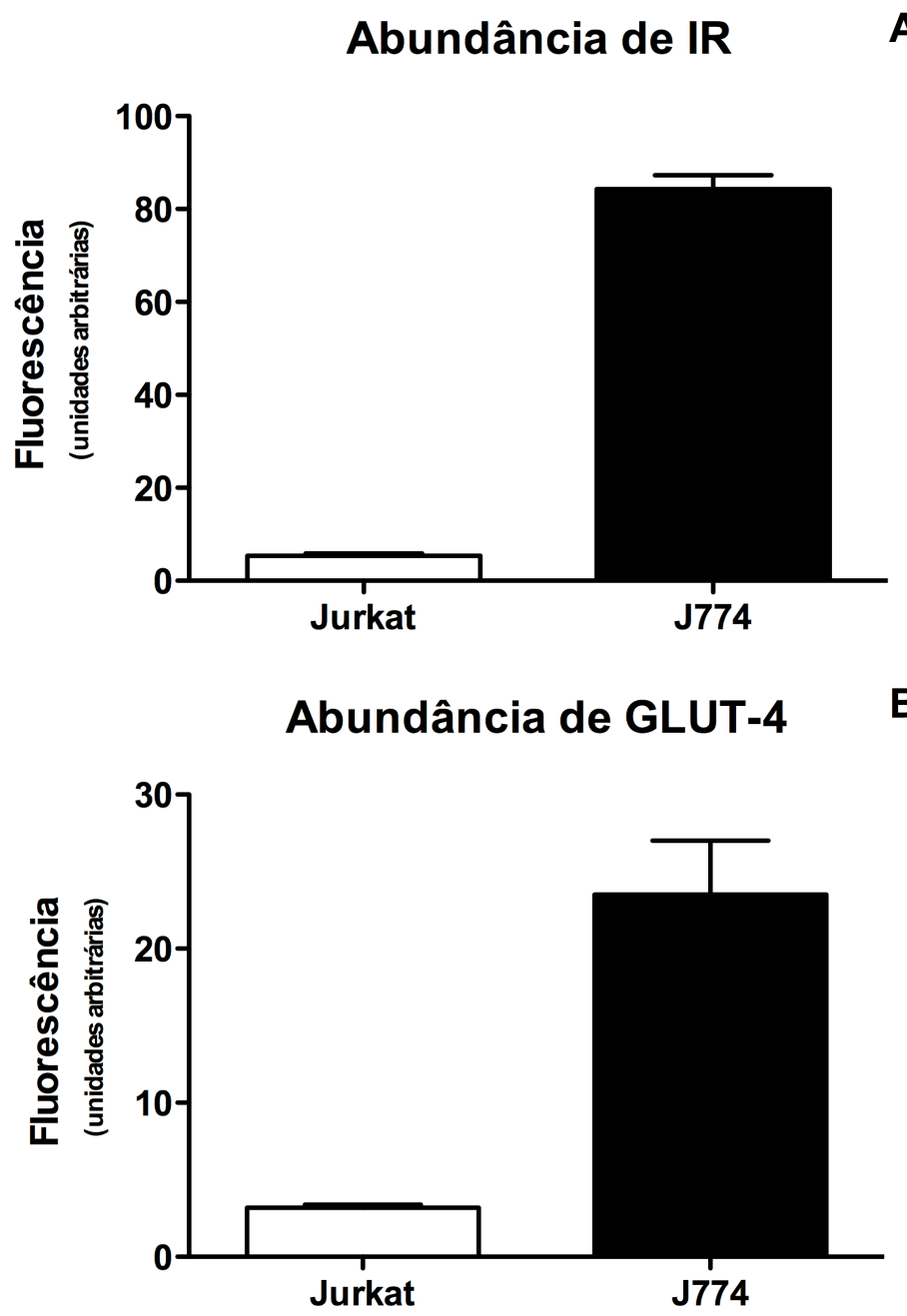

Figura 22 - Análise comparativa da abundância de (A) IR e (B) GLUT-4 em células Jurkat e J774. Os resultados estão expressos como média \pm E.P.M de $n=5$ ensaios. ${ }^{*} p<0,05$ quando comparados ao controle. 
A incubação com PA, estimulou a expressão de ambos IR e GLUT-4 de maneira dose e tempo dependente (Figuras 23 A e C). Há forte correlação dos valores de IR e GLUT-4 com os de fragmentação de DNA; $r^{2}=0,91$ e 0,70, respectivamente (Figuras 23 B e D). Observa-se, portanto, que a expressão destas proteínas está diretamente relacionada com a concentração de PA e também com o processo de apoptose.

A

B
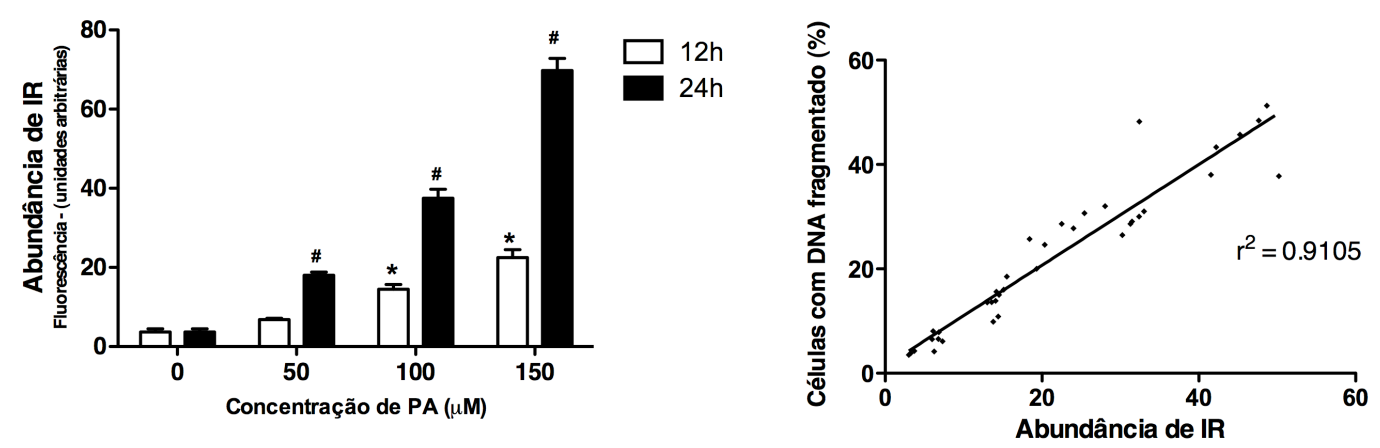

C
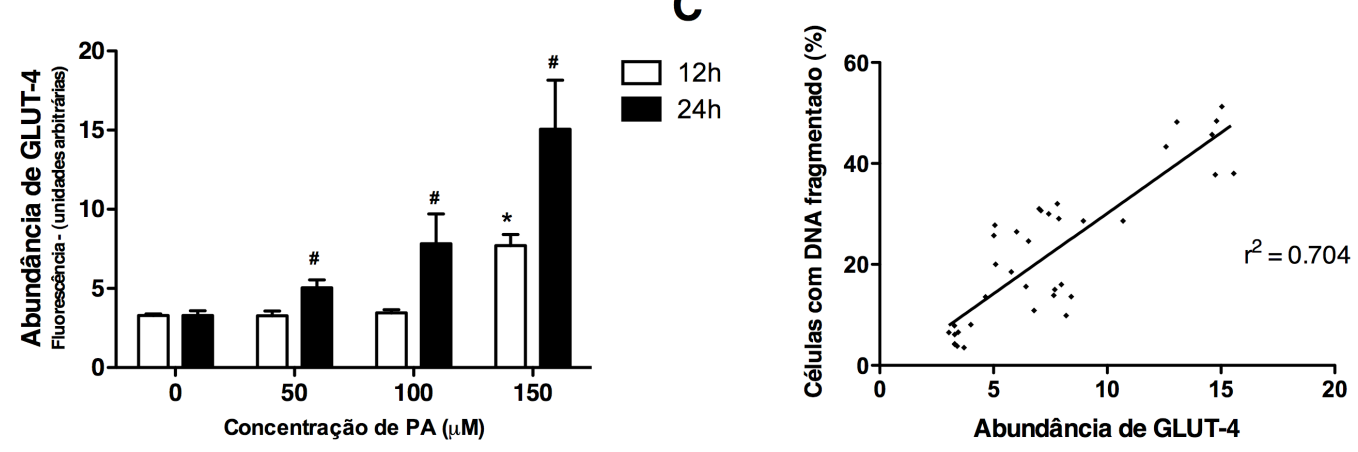

Figura 23 - Efeito do tratamento com PA (50, 100 e $150 \mu \mathrm{M})$ pelo período de 12 e $24 \mathrm{~h}$ sobre a abundância de (A) IR e (C) GLUT-4. Os resultados estão expressos como média \pm E.P.M de $n=7$ ensaios . " $p<0,05$ quando comparado ao controle; * $p<0,001$ quando comparado ao respectivo grupo de $12 \mathrm{~h}$. Correlação entre a expressão de (B) IR e (D) GLUT-4 em relação aos valores de fragmentação de DNA, $r^{2}=0,9105$ e 0,704 , respectivamente. 


\subsubsection{Efeito do PA sobre a via de sinalização de insulina}

Para se determinar o efeito do PA sobre a via de sinalização de insulina, após tratamento por $24 \mathrm{~h}$, foram adicionados às células $10 \mathrm{mU} / \mathrm{mL}$ de insulina e estas foram então incubadas por $30 \mathrm{~min}$. Inicialmente foi analisada a expressão de IR e GLUT-4 por western blotting. Semelhante aos resultados do ensaio de abundância destas proteínas realizado por citometria de fluxo, observa-se que a expressão destas também apresenta relação dependente da dose com a concentração de PA. A incubação com insulina não alterou a expressão destas proteínas, no entanto, embora tenha ocorrido aumento na fosforilação do IR, conforme mostrado na figura 24.

A

PA (uM)

$\begin{array}{llll}0 & 50 & 100 & 150\end{array}$

IP: IR

IP: p-IR

IP: GLUT-4

Continua 


\section{Conclusão}

B

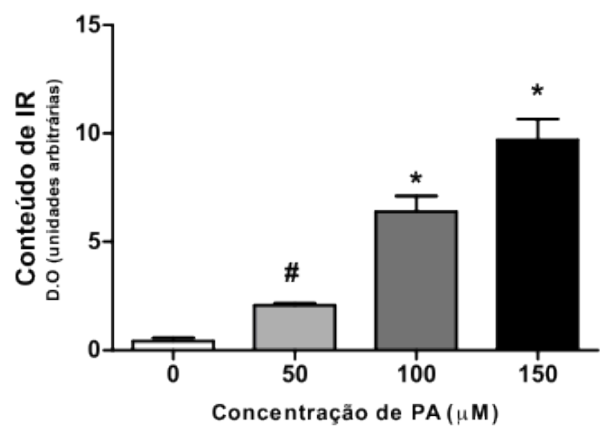

D

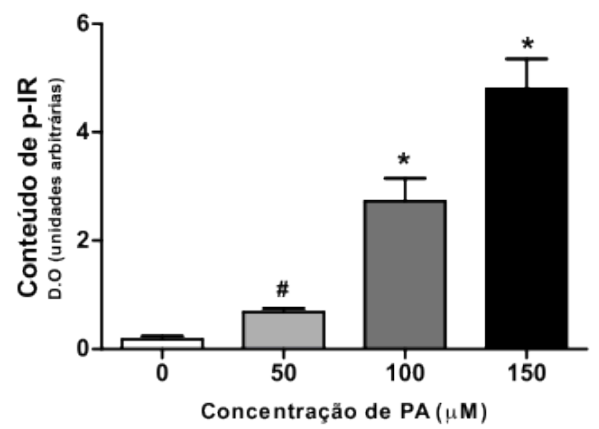

$\mathbf{F}$

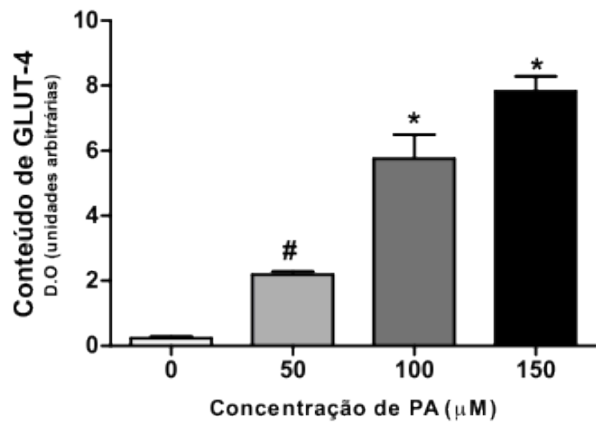

C

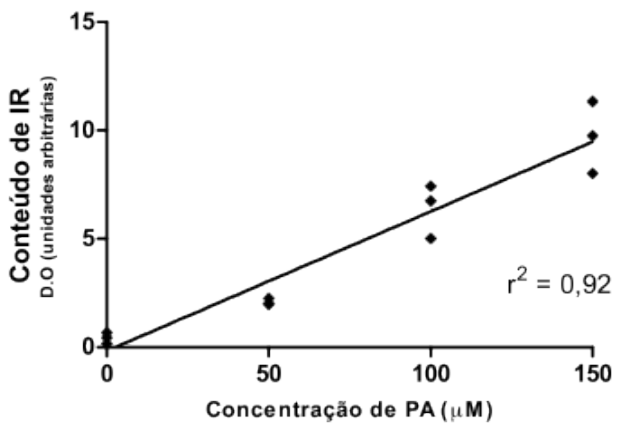

$\mathbf{E}$

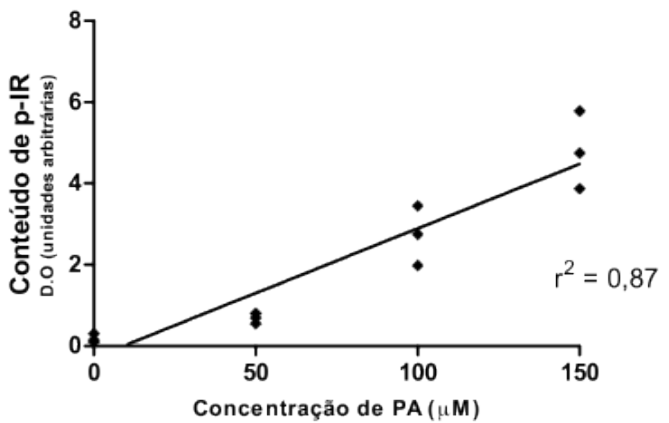

G

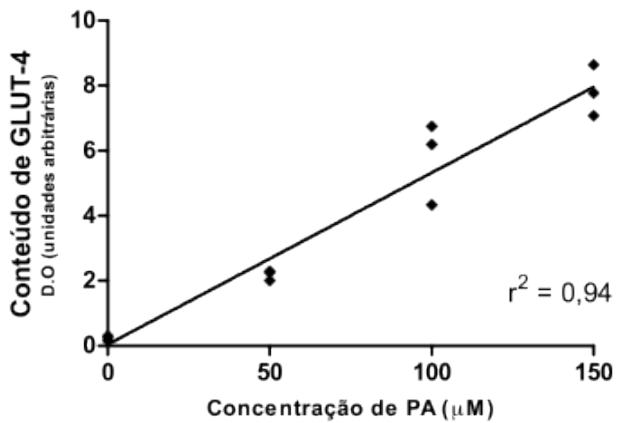

Figura 24 - (A) Análise da expressão das proteínas IR e GLUT-4 após tratamento com PA (50, 100 e 150 $\mu \mathrm{M})$ por $24 \mathrm{~h}$ Análise da fosforilação do IR ( $\mathrm{p}-\mathrm{IR})$ com insulina $(10 \mathrm{mU} / \mathrm{mL})$ por $30 \mathrm{~min}$ após incubação com PA. Amostras com a mesma quantidade de proteínas foram imunoprecipitadas (IP) e analisadas por western blotting após separação protéica por eletroforese em gel de agarose. (B, $\boldsymbol{D}$ e $\boldsymbol{F}$ ) Quantificação do conteúdo de IR, p-IR e GLUT-4 pela densidade ótica, respectivamente. Resultados expressos como média \pm E.P.M. de $n=3$ ensaios. ${ }^{*} \mathrm{p}<0,05 \mathrm{e}{ }^{\#} \mathrm{p}<0,001$ quando comparados ao controle $(\boldsymbol{C}, \boldsymbol{E}$ e $\boldsymbol{G})$ Correlação entre a concentração de PA e o conteúdo de IR, p-IR e GLUT-4, r2 =0,92; 0,87 e 0,94 respectivamente. 
Outras proteínas da via de sinalização da insulina como a IRS-1 e a Akt também foram analisadas. Akt e IRS-1 encontraram-se fosforiladas após a adição da insulina (Figuras 25 e 26 respectivamente). A quantidade da proteína Akt total não foi alterada pela incubação com PA mesmo com a adição de insulina. O tratamento com PA também elevou a quantidade de IRS-1 total. 


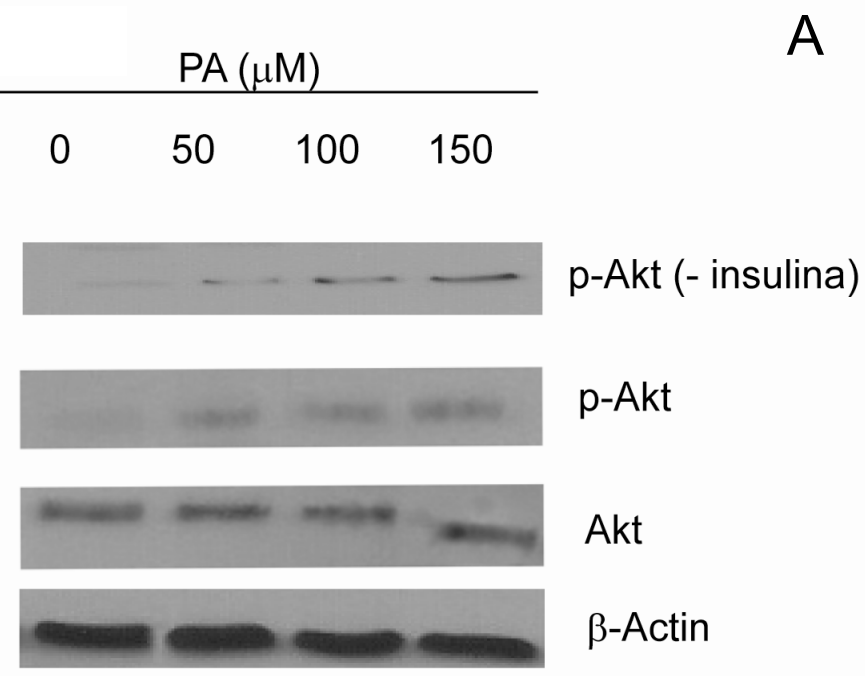

B

Trtamento sem insulina
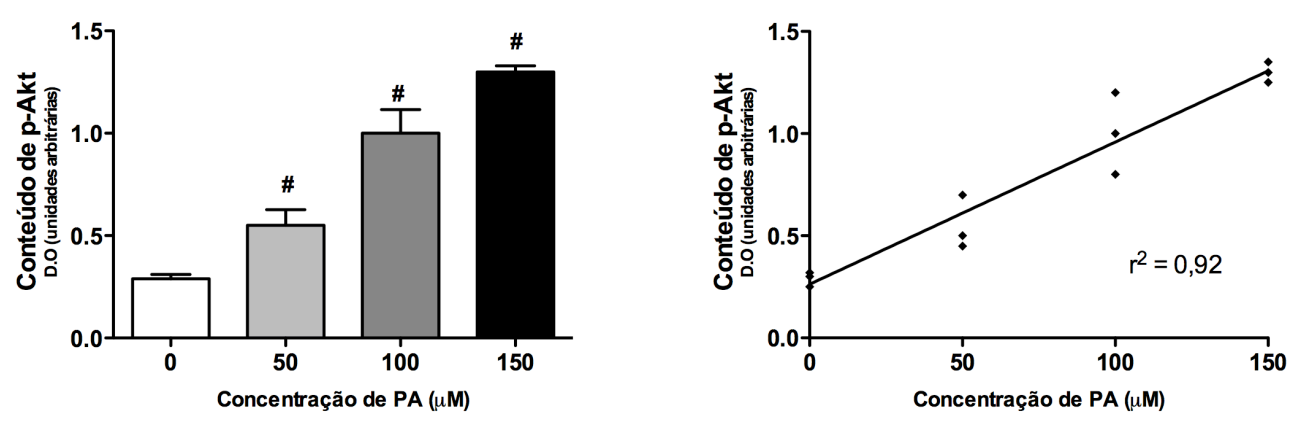

Tratamento com insulina
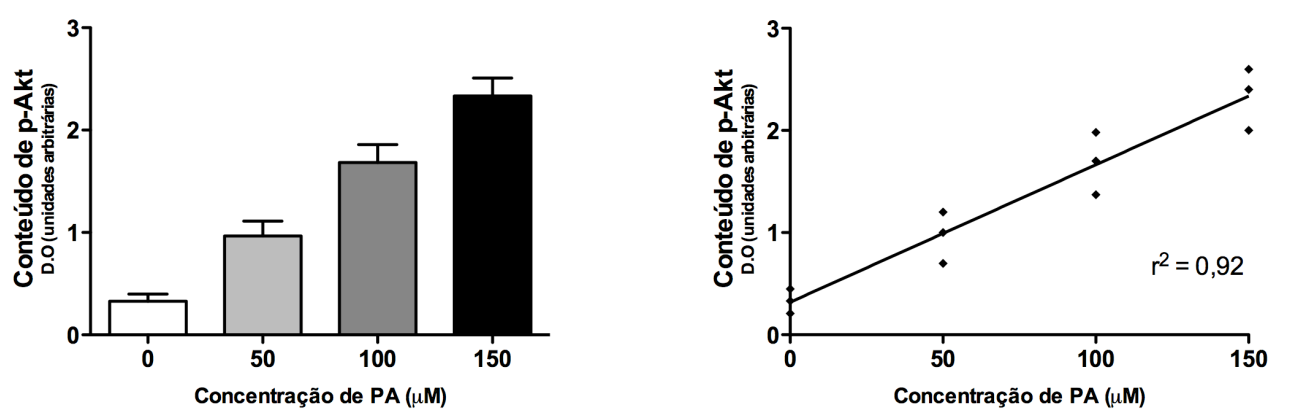

Figura 25 - (A) Avaliação da fosforilação de Akt em células Jurkat incubadas sem insulina e com insulina $(10 \mathrm{mU} / \mathrm{mL})$ por 30 min após tratamento com PA $(50,100$ e $150 \mu \mathrm{M})$ por $24 \mathrm{~h}$. Amostras com a mesma quantidade de proteínas foram imunoprecipitadas e analisadas por western blotting após separação protéica por eletroforese em gel de agarose. (B e D) Quantificação por densidade ótica do conteúdo de p-Akt do grupo sem insulina e pelo tratamento com insulina respectivamente. Os resultados estão expressos como média \pm E.P.M de $n=3$ ensaios. \#p < 0,0001 e ${ }^{*} p<0,001$ quando comparados ao controle. (C e E) Correlação entre a concentração de PA e o conteúdo de p-Akt dos grupos sem insulina e tratado com insulina, respectivamente. 


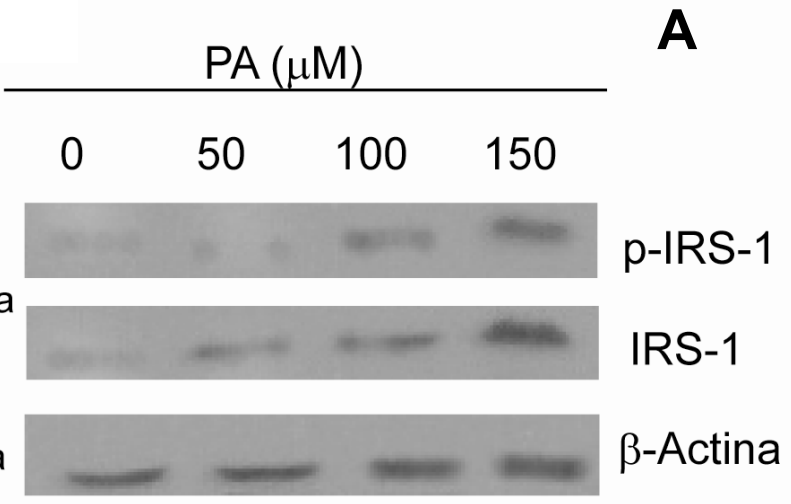

B

C
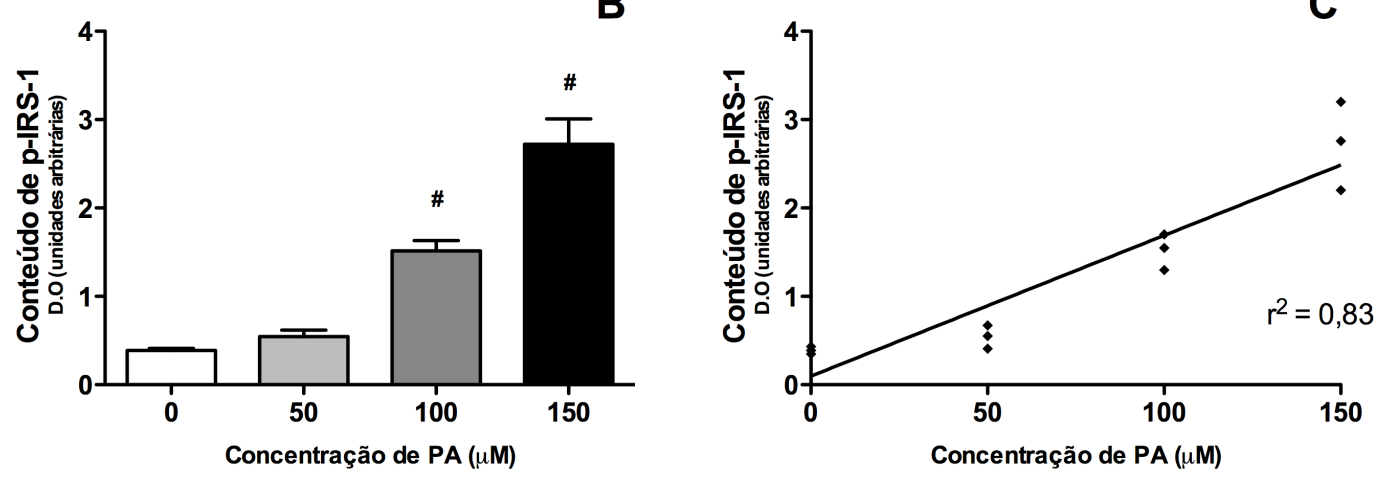

D

$\mathbf{E}$
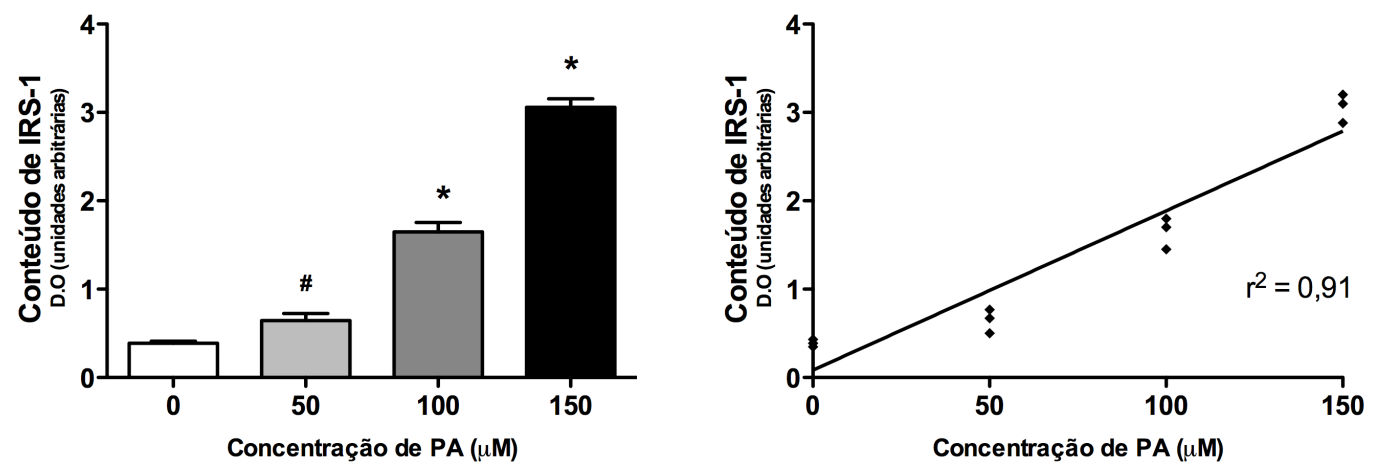

Figura 26 - (A) Avaliação da fosforilação de IRS-1 de células Jurkat incubadas com insulina (10 $\mathrm{mU} / \mathrm{mL})$ por 30 min após tratamento com PA $(50,100$ e $150 \mu \mathrm{M})$ por $24 \mathrm{~h}$. Amostras com a mesma quantidade de proteínas foram analisadas por western blotting após separação protéica por eletroforese em gel de agarose. (B e D) Quantificação por densidade ótica do conteúdo de pIRS-1 e IRS-1 total. Os resultados estão expressos como média \pm E.P.M de n=3 ensaios. \#p $<0,0001$ e *p $<0,001$ quando comparados ao controle. (C e E) Correlação entre a concentração de PA e o conteúdo de p-IRS-1 e IRS-1 total, respectivamente. 


\subsubsection{Efeito do PA sobre o metabolismo de glicose nas células Jurkat}

Devido aos efeitos do PA na via de sinalização da insulina investigou-se se este ácido graxo regula o metabolismo de glicose nas células Jurkat. $O$ tratamento com PA por $24 \mathrm{~h}$ aumentou a captação de glicose de maneira dosedependente. Foi avaliada também a ação da insulina sobre a captação de glicose após tratamento com PA. Na presença do hormônio não houve qualquer efeito quando comparado ao grupo tratado apenas com o ácido graxo (Figura 27A). Em seguida, foi analisada a oxidação da D-[U-14C]-glicose. Ocorreu diminuição da oxidação de glicose de maneira dose dependente frente ao PA. A incubação com insulina não alterou significativamente os valores em relação ao grupo tratado com PA apenas (Figura 27B). 


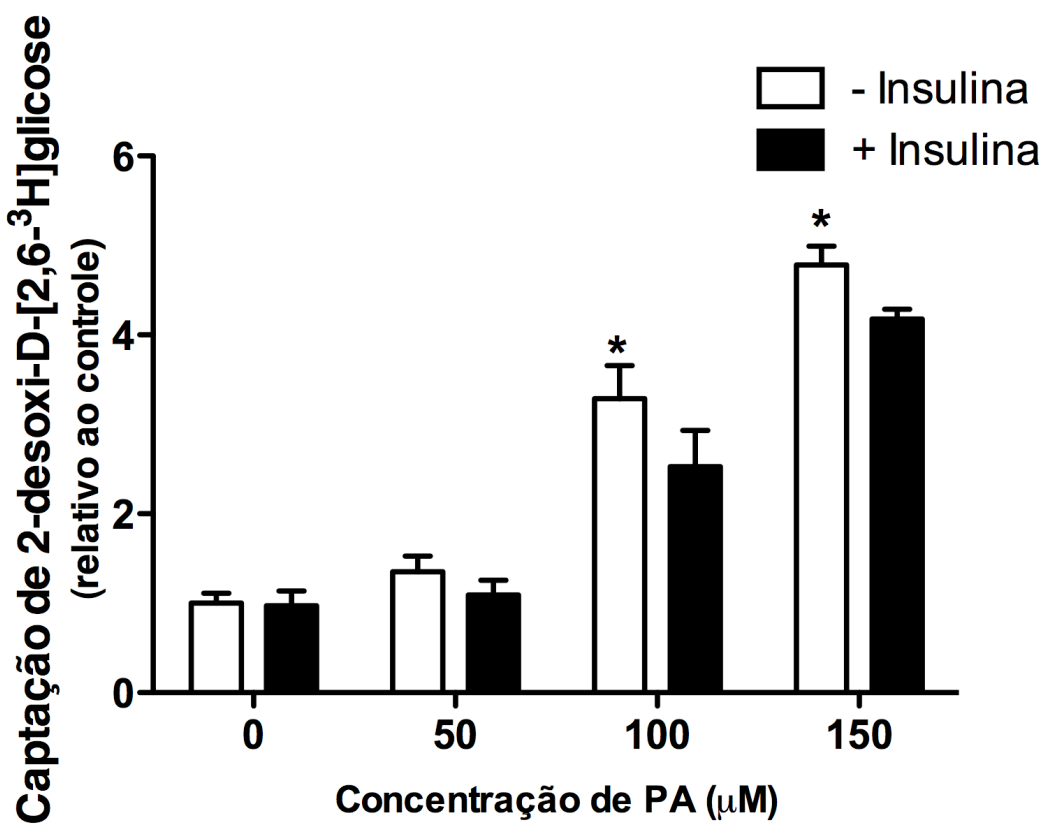

B

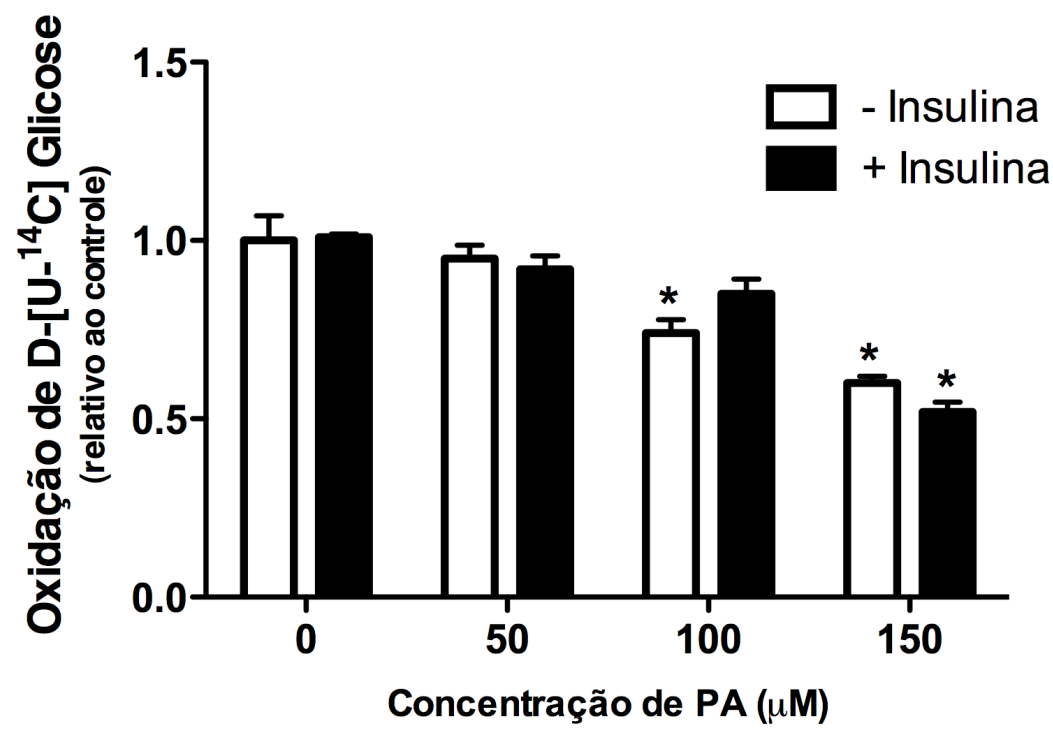

Figura 27 - Efeito do tratamento de PA sobre a (A) captação de glicose e (B) oxidação de glicose em células Jurkat. Os resultados estão expressos como média \pm E.P.M de $n=5$ ensaios. \# $p$ $<0,001$ e ${ }^{*} p<0,05$ quando comparados ao controle. 


\subsubsection{Avaliação do consumo de glicose e glutamina e produção de lactato}

e glutamato

A quantificação dos metabólitos das células tratadas com PA mostrou aumento significativo no consumo de glicose e glutamina. Ao mesmo tempo observou-se aumento na produção de lactato e glutamato.

A

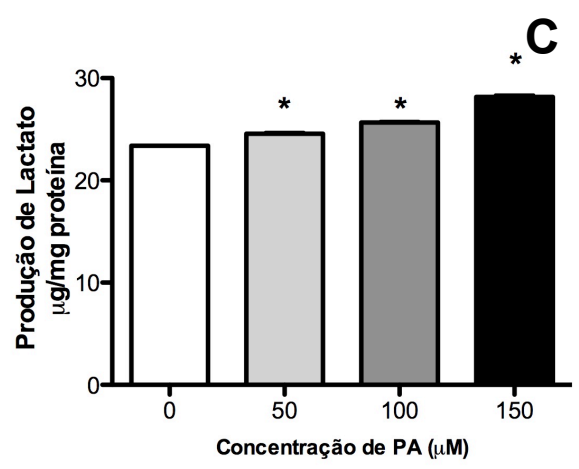

B

D
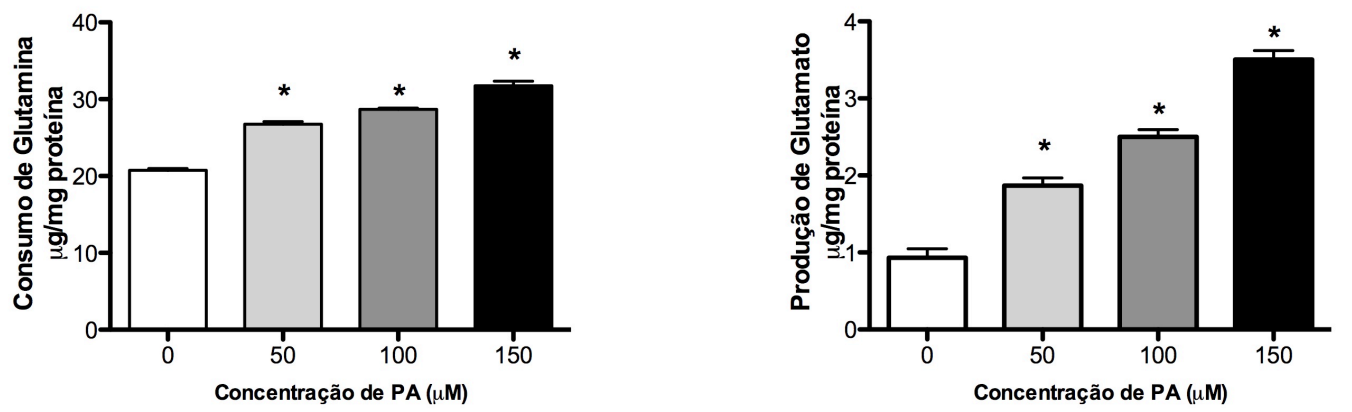

Figura 28 - Efeito do tratamento com PA $(50,100$ e $150 \mu \mathrm{M})$ por 24 h sobre o consumo de glicose e glutamina $(\boldsymbol{A}$ e $\boldsymbol{B})$ e na produção de lactato e glutamato $(\boldsymbol{C}$ e $\boldsymbol{D})$ em células Jurkat. Os resultados estão expressos como média \pm E.P.M de $n=4$ ensaios. ${ }^{*} p<0,05$ quando comparado ao controle. 


\subsubsection{Avaliação do efeito do tratamento com PA na expressão e ativação da AMPK}

A enzima AMPK tem como função ser um sensor energético reagindo à flutuações na razão entre AMP/ATP. A AMPK regula processos metabólicos como a captação de glicose e a $\beta$-oxidação de ácidos graxos. $O$ tratamento com PA ativou a fosforilação da AMPK e também da sua expressão.

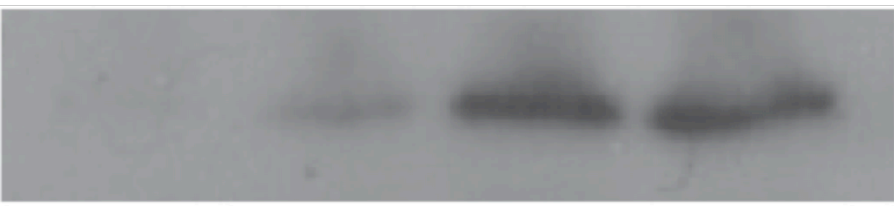

\section{AMPK}

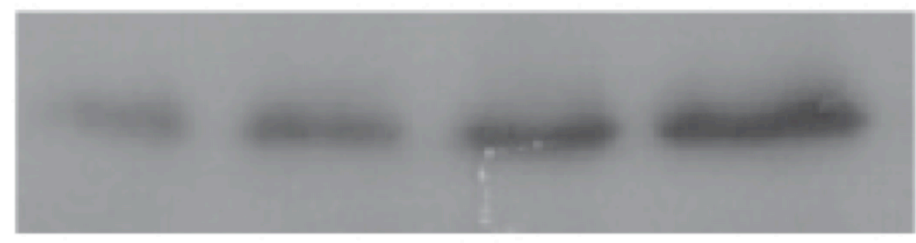

\section{GAPDH}

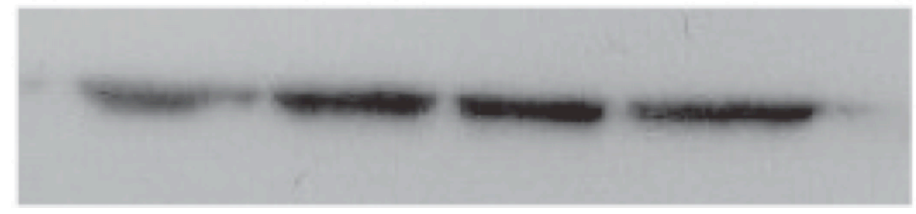

\section{$36 \mathrm{kDa}$}

Figura 29 - Efeito do tratamento de PA sobre a ativação de AMPK células Jurkat. Avaliação da fosforilação de AMPK em células Jurkat após tratamento com PA $(50,100$ e $150 \mu \mathrm{M})$ por $24 \mathrm{~h}$. Amostras com a mesma quantidade de proteínas foram analisadas por western blotting após separação protéica por eletroforese em gel de agarose. 
5.4.6 Efeito do AICAR sobre a fragmentação das células Jurkat tratadas com PA.

As células foram tratadas com PA e concomitantemente com AICAR, um ativador da AMPK, por 24h. O tratamento com a droga no entanto não causou alteração significativa quando comparado ao grupo tratado com PA apenas.

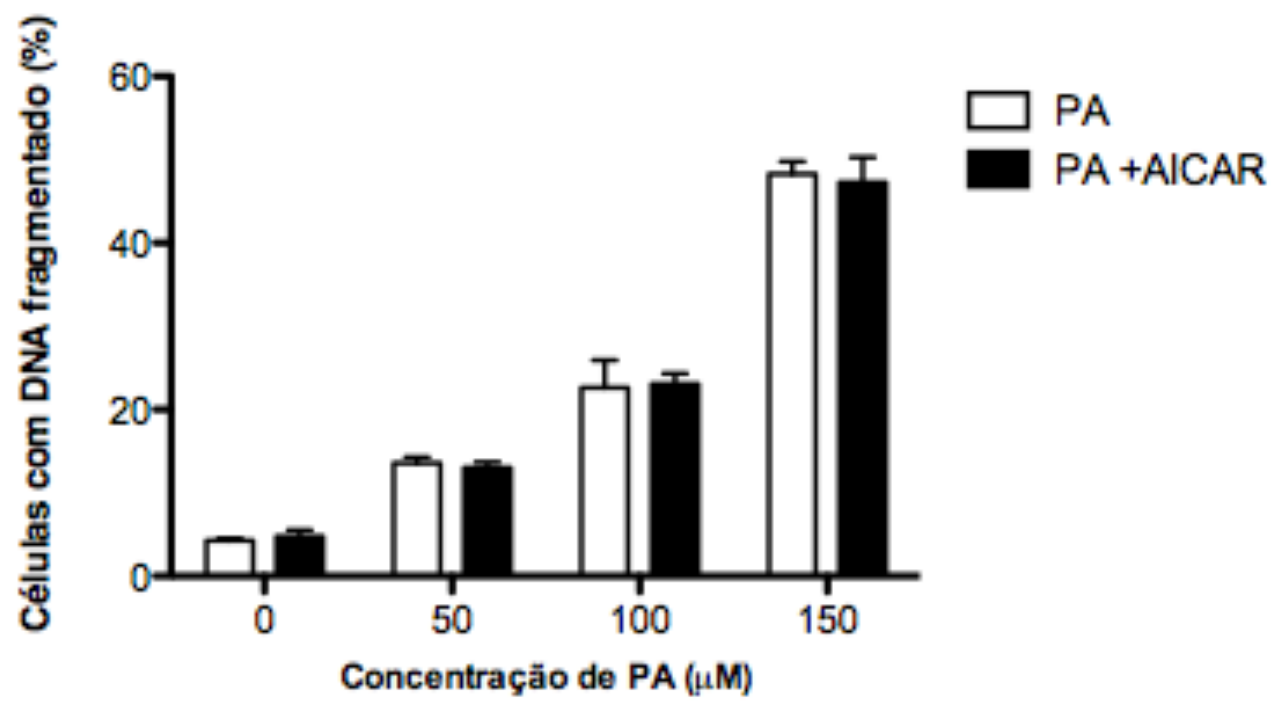

Figura 30 - Efeito do tratamento concomitante com PA e AICAR em células Jurkat. Os resultados estão expressos como média \pm E.P.M de $n=6$ ensaios 
5.4.7 Efeito da insulina sobre a fragmentação das células Jurkat tratadas com PA.

As células foram tratadas com PA e concomitantemente com insulina $(10 \mathrm{mU} / \mathrm{mL})$ por $24 \mathrm{~h}$. O tratamento com o hormônio não mostrou alteração significativa quando comparado ao grupo tratado com PA apenas.

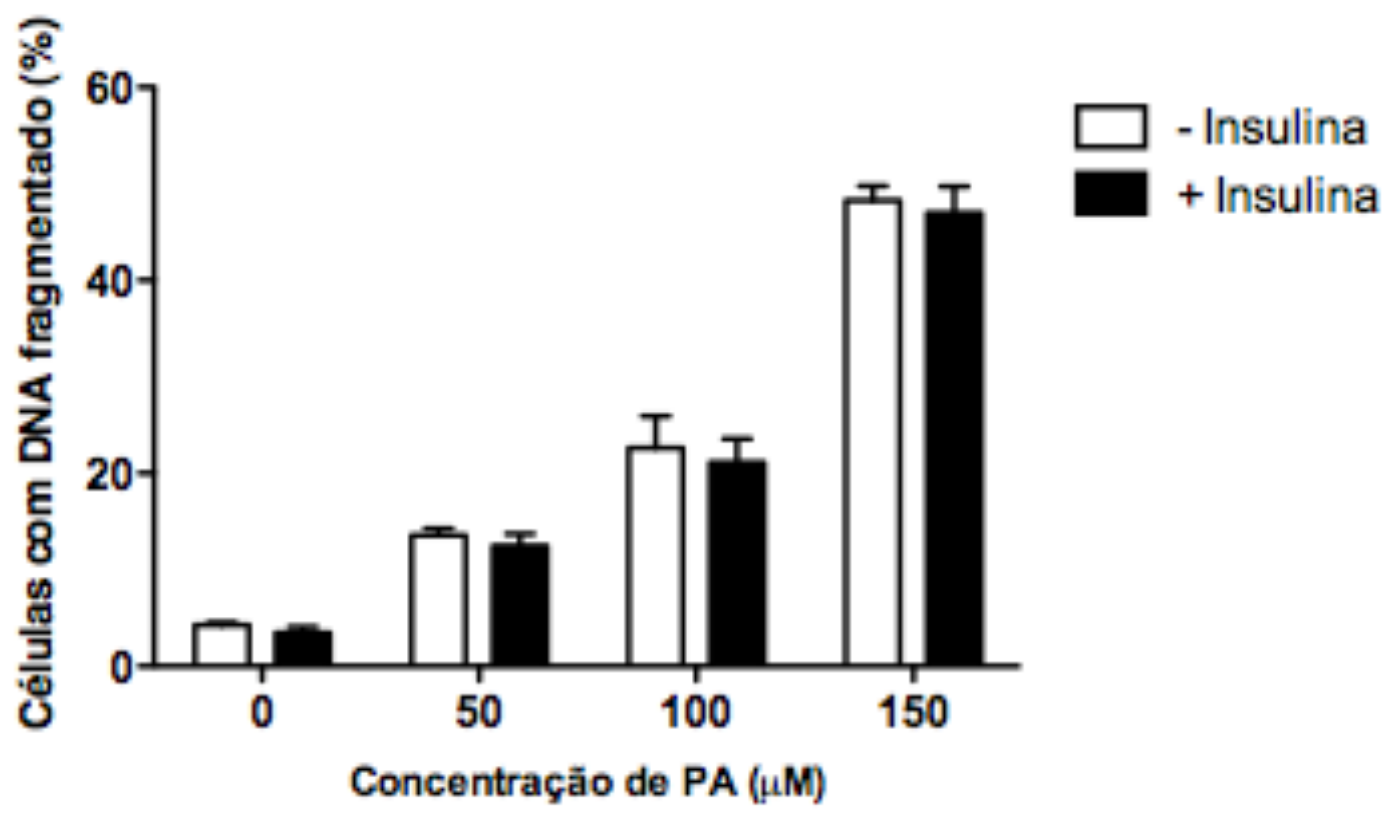

Figura 30 - Efeito do tratamento concomitante com PA e insulina em células Jurkat. Os resultados estão expressos como média \pm E.P.M de $n=5$ ensaios 


\subsection{AVALIAÇÃO DO EFEITO DO PA SOBRE LINFÓCITOS HUMANOS}

Foram realizados ensaios de fragmentação de DNA e abundância de IR e GLUT-4 em linfócitos humanos obtidos de doadores saudáveis. Os resultados foram semelhantes ao obtidos com as células Jurkat.

A

B
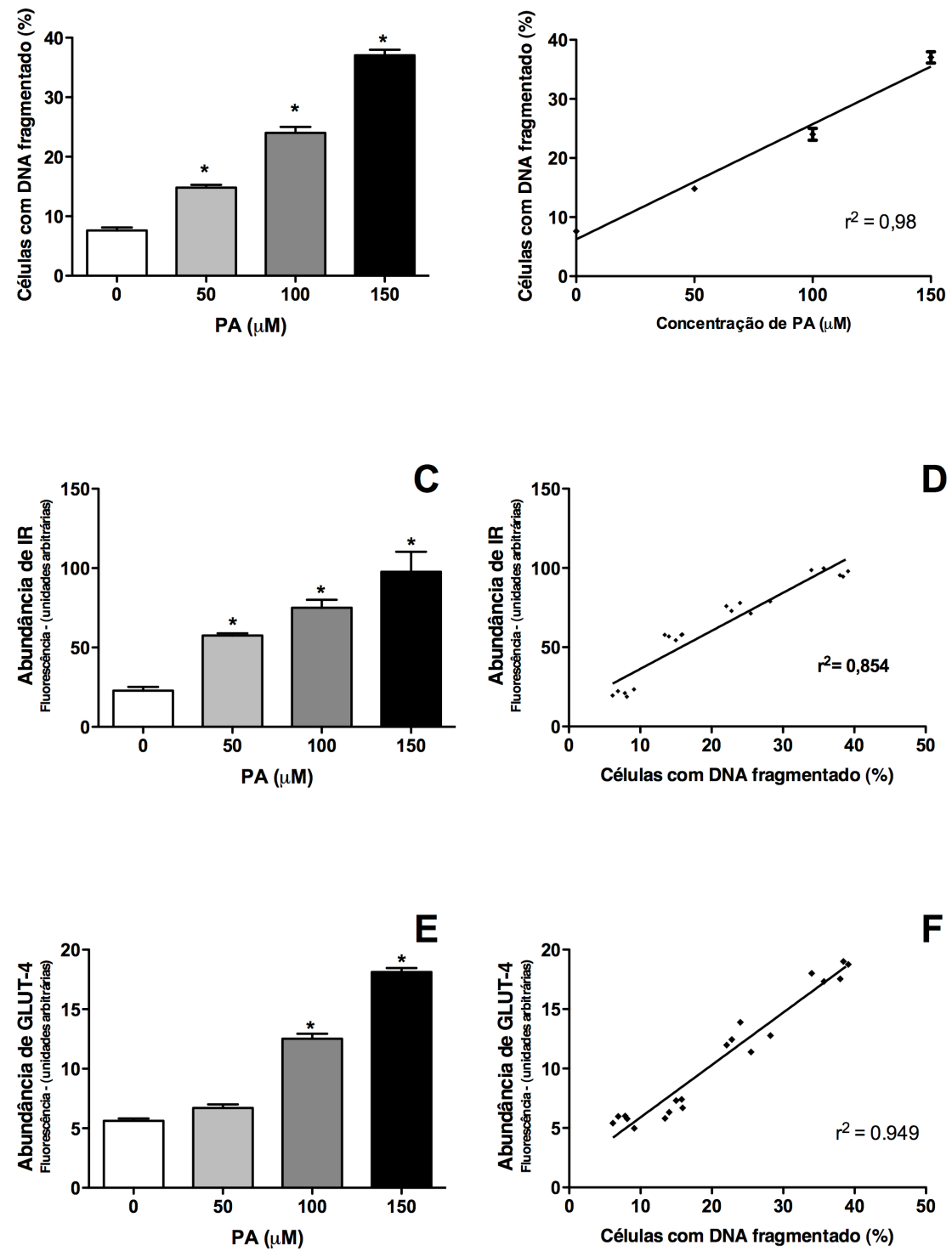

Figura 31 - Efeito do tratamento com PA $(50,100$ e $150 \mu \mathrm{M})$ por 24 h sobre linfócitos humanos quanto a (A) fragmentação de DNA, (C) abundância de IR e (E) abundância de GLUT-4. Os resultados estão expressos como média \pm E.P.M de $n=5$ ensaios. ${ }^{*} p<0,05$ quando comparado ao controle. (B) Correlação entre a concentração de PA e porcentagem de células Jurkat com DNA fragmentado $\left(r^{2}=0,98\right)$. ( $\boldsymbol{D}$ e $\left.\boldsymbol{F}\right)$ Correlação entre a expressão de IR e GLUT-4 em relação aos valores de fragmentação de DNA obtidos após incubação com PA (50, 100 e 150 $\mu \mathrm{M})$ por $24 \mathrm{~h}$ respectivamente. 


\subsection{AVALIAÇÃO DO EFEITO DO JEJUM SOBRE LINFÓCITOS DE RATOS}

\subsubsection{Quantificação de ácidos graxos livres no plasma}

Para estudar o efeito dos ácidos graxos in vivo, ratos Wistar foram submetidos ao jejum por 48 horas. Tal procedimento eleva a concentração de ácidos graxos livres circulantes devido à lipólise no tecido adiposo.

A quantificação dos ácidos graxos livres do plasma de ratos em jejum mostrou-se elevada quando comparada com ratos do grupo controle.

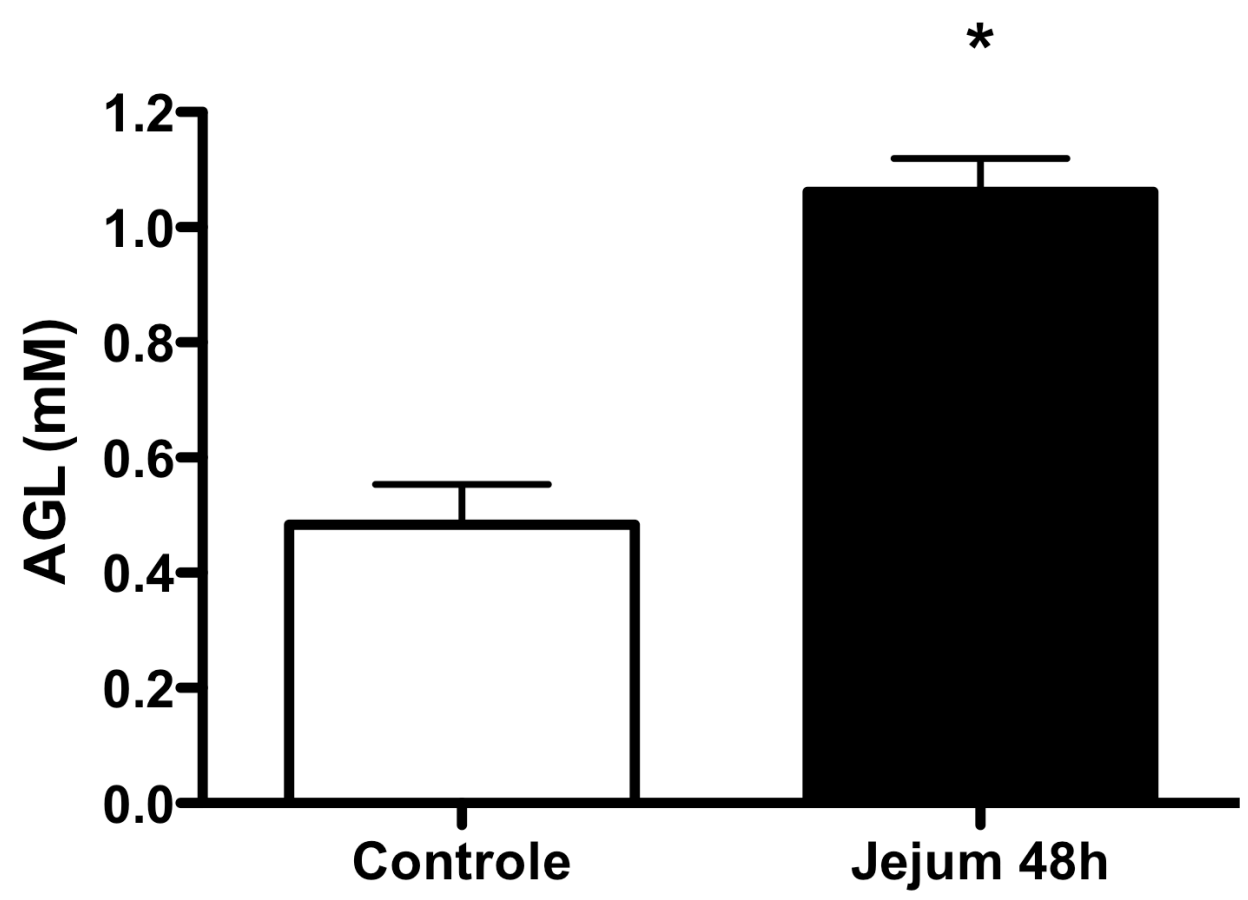

Figura 32 - Quantificação de ácidos graxos livres de ratos mantidos em jejum por 48h. Os resultados estão expressos como média \pm E.P.M de $n=5$ ensaios. ${ }^{*} p<0,012$ quando comparado ao controle. 


\subsubsection{Avaliação do perfil de ácidos graxos do plasma}

A composição de ácidos graxos mostrou aumento das porcentagens de ácidos graxos saturados, especialmente palmítico e esteárico, sendo responsáveis por $85 \%$ do total

Tabela 2 - Valores em porcentagem dos ácidos graxos no plasma de ratos. As análises foram realizadas por separação cromatográfica por HPLC. Os valores estão expressos como média \pm E.P.M. de $n=5$ determinações. ${ }^{*} p<0,05$ quando comparado ao controle.

\begin{tabular}{ccc}
\hline Ácido graxo & Controle & Jejum 48h \\
\hline Láurico (C12:0) & $1,32 \pm 0,17$ & $1,2 \pm 0,05$ \\
Mirístico (C14:0) & $1,95 \pm 0,05$ & $0,7 \pm 0,01$ \\
Palmítico (C16:0) & $30,87 \pm 2,38$ & $45,11 \pm 3,4^{*}$ \\
Esteárico (C18:0) & $17,5 \pm 1,8$ & $30,22 \pm 2,2^{*}$ \\
Palmitoleico (C16:1) & $3,81 \pm 0,88$ & $1,2 \pm 0,21^{*}$ \\
Oleico (C18:1) & $24,87 \pm 0,34$ & $11,8 \pm 0,64^{*}$ \\
Linoleico (C18:2) & $15,09 \pm 0,30$ & $6,2 \pm 0,57^{*}$ \\
Y-Linolênico (C18:3) & $0,31 \pm 0,03$ & $0,3 \pm 0,02$ \\
Araquidônico (C20:4) & $2,25 \pm 0,39$ & $2,37 \pm 0,48$ \\
Eicosapentaenóico (C20:5) & $1,61 \pm 0,05$ & $0,3 \pm 0,01^{*}$ \\
Docosa-hexaenóico (C22:6) & $0,42 \pm 0,21$ & $0,6 \pm 0,3$ \\
\hline
\end{tabular}




\subsubsection{Avaliação do efeito do PA sobre linfócitos de ratos}

Foram realizados ensaios de fragmentação de DNA e abundância de IR e GLUT-4 em linfócitos de ratos em jejum por 48h. Os resultados foram semelhantes ao obtidos com as células Jurkat.
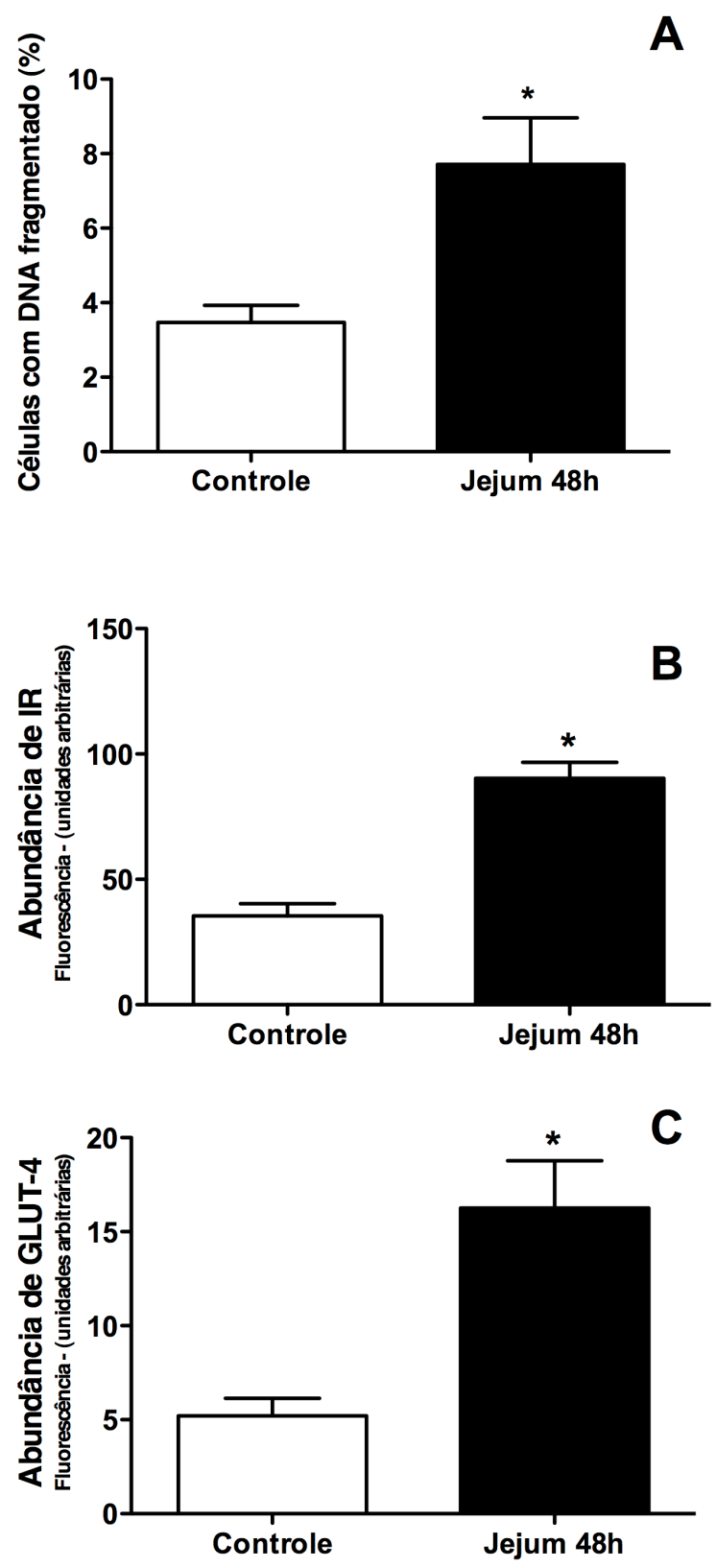

Figura 33 - Efeito do tratamento com PA $(50,100$ e $150 \mu \mathrm{M})$ tratado por $24 \mathrm{~h}$ sobre linfócitos de ratos quanto a $(\boldsymbol{A})$ fragmentação de DNA, (B) abundância de IR e (C) abundância de GLUT-4. Os resultados estão expressos como média \pm E.P.M de $n=5$ ensaios. ${ }^{*} p<0,001$ quando comparado ao controle. 


\subsection{AVALIAÇÃO DOS EFEITOS DOS INDUTORES DE APOPTOSE, ESTAUROSPORINA E ETOPOSIDE SOBRE A EXPRESSÃO DE IR E GLUT-4}

Foram realizados ensaios de fragmentação de DNA e abundância de IR e GLUT-4 em células Jurkat tratadas com agentes indutores de apoptose estaurosporina e etoposide. A estaurosporina é um inibidor de quinases de proteínas não seletivo que compete com o ATP pelo sítio de ligação e participa do processo de apoptose através da ativação da caspase 3 (Chae et al., 2000). O etoposide é um inibidor da enzima topoisomerase II, inibindo, portanto, o processo de replicação do DNA (Montecucco et al., 2007).

As doses utilizadas destes agentes nas células Jurkat foram: 0,25, 0,50 e $1 \mu \mathrm{M}$ por $24 \mathrm{~h}$. Os resultados obtidos foram semelhantes aos encontrados nos ensaios com células Jurkat incubadas com PA.

A estaurosporina apresenta maior toxicidade que o etoposide como pode ser observado no ensaio de fragmentação de DNA (Figura 34A). A estaurosporina e o etoposide aumentaram significativamente a abundância de IR e GLUT-4. Não houve diferença significativa entre os dois agentes indutores de apoptose quanto à abundância de IR e GLUT-4 (Figuras 34C e E). 


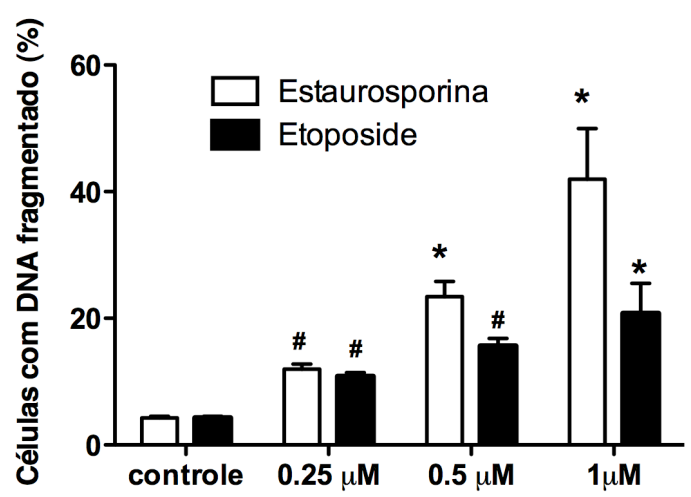

A

B

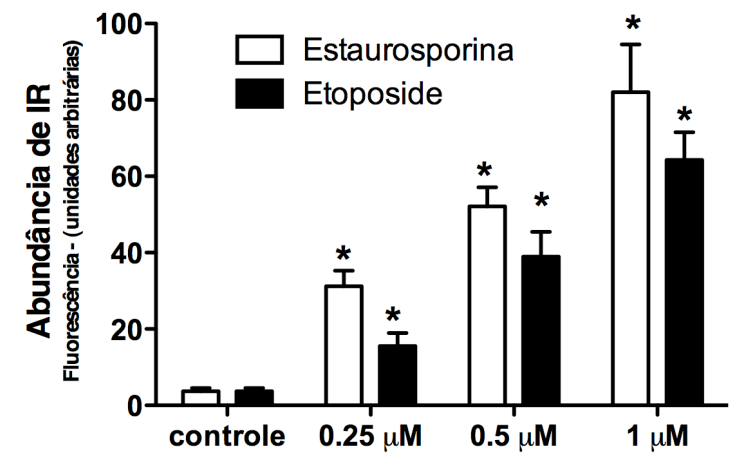

C

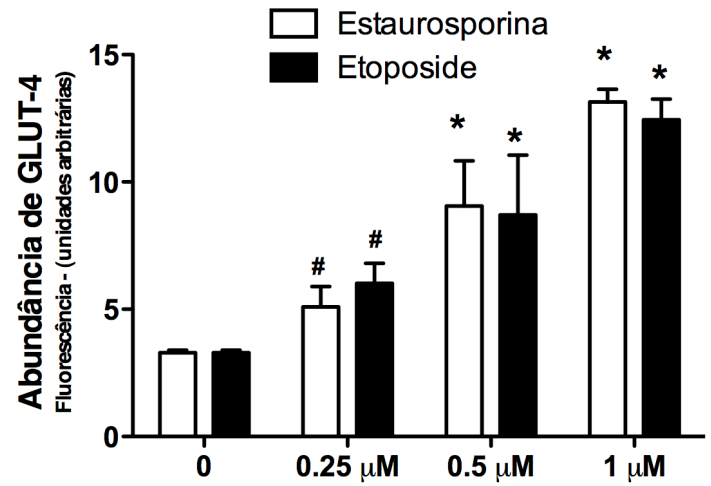

Figura 34 - Avaliação por citometria de fluxo do efeito da estaurosporina e do etoposide sobre (A) fragmentação de DNA, abundância de (C) IR e (E) GLUT-4 em células Jurkat no período de 24h. Resultados estão expressos como média \pm E.P.M de $n=5$ ensaios. * $p<0,05$ e ${ }^{\#} p<$ 0,001 quando comparados ao controle. (B) Correlação entre a concentração de estaurosporina ou etoposide e a fragmentação de DNA de células Jurkat. (D e F) 


\subsection{AVALIAÇÃO DAATIVIDADE DO NF-kB EM CÉLULAS JURKAT}

Foi avaliado o efeito do PA sobre a ativação de NF-kB no período de $2 \mathrm{~h}$ de incubação. O PA induziu ativação do NF-kB de forma dose dependente. $\mathrm{O}$ indutor de apoptose estaurosporina não induziu de maneira significativa a ativação do NF-kB quando comparado ao controle.
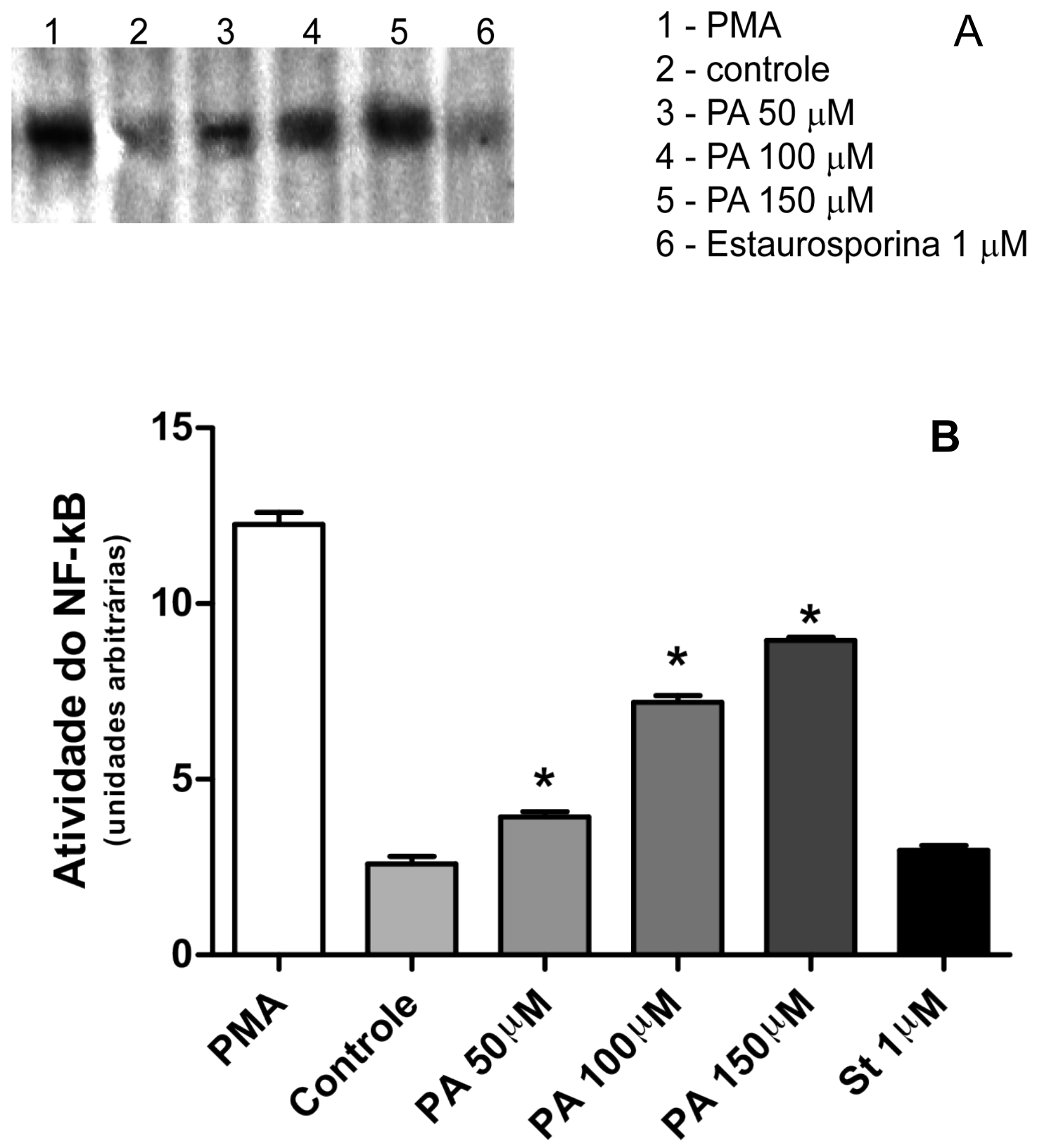

Figura 35 - Efeito do PA e da estaurosporina na ativação do NF-kB de células Jurkat após $2 \mathrm{~h}$ de incubação. Proteínas nucleares foram extraídas e submetidas ao EMSA. (B) Análise densitométrica do NF-kB. Resultados apresentados como média \pm E.P.M de $n=4$ ensaios. * $p<0,001$ quando comparado ao controle. 


\section{DISCUSSÃO}

O PA induziu apoptose das células Jurkat conforme observado pelos ensaios de fragmentação de DNA, despolarização da membrana mitocondrial, liberação de citocromo c para o citoplasma e ativação das caspases 3 e 9 . Estes achados são indicativos de que o PA leva à morte destas células por ativação da via intrínseca de morte, na qual há o envolvimento da mitocôndria. Além disso, foram observados geração e acúmulo de ROS e NO que podem ter contribuído para o disparo do processo apoptótico. Concomitantemente, células tratadas com PA apresentaram aumento do conteúdo de IR e GLUT-4 na membrana plasmática mesmo sem tratamento com insulina. $\mathrm{O}$ tratamento com PA aumentou a captação de glicose, mas diminuiu a sua conversão à $\mathrm{CO}_{2}$ e elevou o conteúdo de classes lipídicas como triacilgliceróis, ésteres de colesterol, ácidos graxos livres e fosfolipídeos.

A mitocôndria apresenta função muito importante na regulação da apoptose. Proteínas pró-apoptóticas como o citocromo c, Smac/DIABLO e AIF estão confinadas no espaço transmembrânico mitocondrial e são liberadas em resposta a estímulos apoptóticos como depleção de fatores de crescimento, exposição à radiação UV e produção de espécies reativas de oxigênio (CHIPUK;BOUCHIER-HAYES;GREEN, 2006; GARRIDO et al., 2006). A injúria mitocondrial é mediada pela abertura dos poros de transição de permeabilidade que leva à despolarização da membrana mitocondrial e a liberação do conteúdo da matriz e da membrana interna para o citossol como o citocromo c (Green et al., 1998; Kroemer et al., 1998). O tratamento com PA aumentou a proporção de células Jurkat com membrana mitocondrial despolarizada de maneira dose dependente. Cury-Boaventura et al. (2004; 2006). demonstraram que os ácidos oleico e linoleico provocam a morte de linfócitos humanos e de células Jurkat por apoptose. Estes autores também observaram aumento na despolarização da membrana mitocondrial e associaram esta mudança com a produção de ROS e quebra do balanço redox.

O citocromo c promove ativação da caspase 9 através da formação de complexo com a Apaf-1 que cliva e ativa a caspase 3 (ZOU et al., 1999). Esta caspase é um dos executores importantes da apoptose sendo responsável 
pela clivagem proteolítica de proteínas como a PARP (COHEN, 1997). O PA elevou a liberação de citocromo $\mathrm{c}$ das mitocôndrias das células Jurkat para o citossol e ativou as caspases 3 e 9 .

O tratamento com PA aumentou a fosforilação da PKC-ס, uma isoforma da superfamília das PKCs, que atua como regulador importante da apoptose. A ativação da $\mathrm{PKC}-\delta$ pode ser iniciada por uma variedade de estímulos incluindo radiação ionizante, agentes anti-cancerígenos, ROS, radiação ultravioleta, fatores de crescimento e citocinas (YOSHIDA, 2007). Os mecanismos moleculares de ativação da PKC- $\delta$ envolvem fosforilação do resíduo de tirosina ou clivagem proteolítica pela caspase 3 . Dependendo do tipo celular e do estímulo apoptótico, a PKC- $\delta$ transloca-se para organelas subcelulares como o núcleo, mitocôndria, complexo de Golgi, retículo endoplasmático e membrana plasmática (BRODIE e BLUMBERG, 2003). Um dos alvos principais é a mitocôndria. A ativação de PKC-ס causa alteração no potencial de membrana mitocondrial e na liberação de citocromo c das mitocôndrias (MAJUMDER et al., 2000; SUMITOMO et al., 2002).

O PA aumentou a fosforilação das proteínas JNK e p38 MAPK, membros da superfamília das MAPK, que são responsivas a estímulos estressantes como choque osmótico, disfunção do retículo endoplasmático, exposição à radiação ionizante, estimulação por citocinas e acúmulo de ROS (LIU et al., 1996; URANO et al., 2000; PEARSON et al., 2001). Em estudos recentes, Ogino et al (2009) e Lee et al (2009) demonstraram ativação da via da JNK em células Jurkat no processo de apoptose utilizando a monocloramina, um oxidante derivado de neutrófilos, e a lactoferrina, uma glicoproteína ligadora de ferro, respectivamente. Em nossos estudos foi também observado que 0 tratamento com PA estimula a fosforilação da proteína ERK em células Jurkat. A ERK também pertence à família das MAPK e está envolvida na sobrevivência e proliferação das células. A ERK é uma serina/treonina quinase que fosforila inúmeras proteínas como proteínas quinases, receptores, proteínas de citoesqueleto e fatores de transcrição (PEARSON et al., 2001; YOON e SEGER, 2006). A ERK participa do processo de proliferação celular, na progressão da fase $\mathrm{G} 1$ para $\mathrm{S}$ e está associada à indução de reguladores 
positivos do ciclo celular e na inativação de genes anti-proliferativos (MELOCHE e POUYSSEGUR, 2007). Em estudo realizado com células RINm5F (células de linhagem pancreática de ratos), foi observado que a exposição ao PA por 4h causa uma ativação persistente da ERK. Após este período, no entanto, observa-se o efeito citotóxico através da ativação da PKC $\delta$, sobrepujando-se à tentativa de sobrevivência da célula (SIMON et al., 2008). Além disso, a ERK pode participar do processo de apoptose também através da retenção da sua forma ativa no citossol o que impede o seu envolvimento com fatores de transcrição que são responsáveis pela resposta mitogênica. $A$ retenção de ERK no citossol potencializa a atividade catalítica de proteínas próapoptóticas como a DAP quinase (MEBRATU e TESFAIGZI, 2009).

Diversos mecanismos têm sido postulados em relação aos efeitos apoptóticos de ácidos graxos tais como: geração de ROS (CACICEDO et al., 2005; WU et al., 2009), síntese de NO (BOSCA et al., 2005) e síntese de novo de ceramidas (MERRILL, 2002). A contribuição relativa destes mecanismos varia de acordo com a concentração do agente apoptótico, tempo de incubação e o tipo celular utilizado. Em nosso estudo foi constatado que o tratamento com PA aumenta a formação e acúmulo de ROS, em especial de superóxido e peróxido de hidrogênio.

Skulachev (1991) propôs um modelo no qual o movimento de AG protonados para a matriz mitocondrial é regido passivamente pelo $\Delta \mathrm{pH}$ da bicamada fosfolipídica da membrana interna, conhecido por mecanismo flipflop. Os AG possuem a capacidade de desacoplar a fosforilação oxidativa principalmente nos complexos I e III da cadeia transportadora de elétrons, alterando o estado redox da célula e induzindo a produção excessiva de ROS, especialmente superóxido e peróxido de hidrogênio, e diminuindo a razão ATP/ ADP (KORSHUNOV et al., 1998). Além disso, os AG podem induzir abertura dos poros de transição de permeabilidade permitindo o extravasamento de proteínas pró-apoptóticas como o citocromo c, AIF e Smac/DIABLO. Em trabalho utilizando músculo esquelético de ratos foi verificado que a incubação com PA aumenta a produção de ROS através de desacoplamento mitocondrial. Resultados com o uso de bromopalmitato e etomoxir (inibidor da CPT-I) 
indicaram que o PA precisa ser oxidado para induzir a produção de ROS (LAMBERTUCCl et al., 2008).

Em nosso estudo verificamos uma diminuição da concentração de GSH e uma queda da razão GSG/GSSG de maneira dose-dependente ao tratamento com PA. O estresse oxidativo é um estado de desequilíbrio redox. A razão entre GSH e GSSG é utilizada para expressar o nível do estresse oxidativo na célula (HALLIWELL e GUTTERIDGE, 1999). A razão GSH/GSSG não só desempenha função importante como regulador homeostático do balanço redox na célula mas também atua como sensor que dispara respostas celulares protetoras ou injuriosas. A GSH é o antioxidante predominante contra os efeitos tóxicos de ROS, particularmente na mitocondria (DELEVE e KAPLOWITZ, 1991; XIAO et al., 2003) e também está envolvida em diversos processos celulares como destoxificação de drogas, sinalização celular e proliferação celular (WU et al., 2004). A diminuição intracelular do conteúdo de GSH é um marcador da progressão de apoptose (HAMMOND;MADEJCZYK;BALLATORI, 2004; FRANCO e CIDLOWSKI, 2006). Em estudo conduzido por Pasini et al (1991), foi estudado o efeito tóxico dos AG durante a reperfusão miocárdica em ratos e verificou-se que o palmitato causa uma grande injúria durante o período de recuperação e também uma queda brusca na razão GSH/GSSG. Em células de linhagem hepática HepG2 foi verificado que a exposição crônica ao PA é tóxica e induz morte celular quando comparado ao ácido oleico. A toxicidade do PA relacionou-se à diminuição da síntese de $\mathrm{GSH}$ devido à limitação da captação de cisteína pela célula. $\mathrm{O}$ uso de doadores de cisteína como a Nacetil-cisteína (NAC) diminuiu a toxicidade do PA nestas células (SRIVASTAVA e CHAN, 2008).

Apesar da função crítica da GSH ser crítico no controle redox e na ativação da apoptose, Franco et al (2007) demonstraram em células Jurkat que a depleção de GSH é necessária para a morte destas células independentemente da formação de ROS, sendo comprovada após a indução de apoptose por indutores como a FasL e o uso concomitante de antioxidantes. Para os autores, a GSH pode estar envolvida no controle pós-transcricional de 
proteínas da cascata de apoptose, visto que a morte celular em condições anaeróbias é observada a depleção de GSH (JACOBSON e RAFF, 1995).

Além do estresse oxidativo, o tratamento das células Jurkat com PA induziu também aumento do estresse nitrosativo com o aumento de $\mathrm{NO}$ e da expressão da iNOS. O NO produzido em excesso pode competir com o oxigênio pelo complexo IV da cadeia de transporte de elétrons, o que acarreta no impareamento da fosforilação oxidativa, diminuição da produção de ATP (MONCADA e ERUSALIMSKY, 2002) e na desregulação da homeostase intracelular de $\left[\mathrm{Ca}^{2+}\right]$, induzindo estresse de retículo (XU et al., 2004). O NO pode também reagir com superóxido e formar peroxinitrito, um potente oxidante. Como resultado, o $\mathrm{NO}$ e os seus derivados podem induzir injúrias na célula como a quebra do DNA e degradação de proteínas (YASMIN;STRYNADKA;SCHULZ, 1997; XU et al., 2004). Em estudo conduzido por Abraviciene et al (2008), a exposição crônica de ilhotas pancreáticas a PA induziu expressão de iNOS, e ativação das proteínas JNK e caspase 3, levando o impareamento da secreção de insulina. O tratamento com rosiglitazona suprimiu a expressão e a ativação destas proteínas e restaurou a secreção do hormônio. Em estudo realizado por Kiang et al (2008), foi mostrado que em células Jurkat induzidas à apoptose por hipóxia química, utilizando cianeto de sódio ( $\mathrm{NaCN}$ ) há aumento da expressão de iNOS da produção de $\mathrm{NO}$ e na da geração de leucotrieno $\mathrm{B}_{4}\left(\mathrm{LTB}_{4}\right)$ e peroxidação lipídica. No mesmo estudo, os autores bloquearam a expressão do gene da iNOS e verificaram diminuição da morte celular e produção de $\mathrm{LTB}_{4}$ e da peroxidação lipídica. Apesar do efeito deletério do NO, Zhang et al (2009) mostraram que na apoptose de células Jurkat mediada por Níquel há depleção de GSH, aumento de ROS e uma diminuição da expressão de iNOS e da produção de NO. A utilização de NAC elevou a razão GSH/GSSG e a expressão de iNOS e a produção de NO. Neste modelo a apoptose por níquel é devido ao efeito tóxico da produção de ROS e redução de NO, regulado pela $\mathrm{GSH}$, e que pode conferir um efeito citoprotetor à célula.

O tratamento com PA induziu despolarização mitocondrial e o aumento da produção de ROS, que podem ter contribuído para diminuição da razão ATP/ 
AMP, visto que há aumento da ativação da AMPK de maneira dose dependente ao ácido graxo. Embora a AMPK atue como um sensor energético induzindo o transporte de glicose e a oxidação de ácidos graxos em cenários de depleção energética, esta enzima pode inibir os efeitos apoptóticos do PA. A AMPK poderia inibir a morte celular através da diminuição/inibição da produção de ROS mitocondrial induzindo aumento da expressão de antioxidantes como as proteínas desacopladoras (UCP - uncoupling proteins) (KUKIDOME et al., 2006). Kim et al (2008) em estudo com células endoteliais de aorta bovina, verificaram que a incubação com PA induz a morte dessas células pela produção de ROS e ativação da proteína pró-apoptótica p38. O uso do ativador da AMPK, AICAR, possibilitou a inibição da apoptose diminuindo a produção de ROS pelo aumento da expressão de UCP-2 e supressão da p38. Em nosso estudo, no entanto, foi verificado que a incubação concomitante do AICAR com PA não inibiu a morte celular.

Células Jurkat tratadas com PA apresentaram aumento da expressão de IR e GLUT-4. Linfócitos T, diferentemente de monócitos, exibem concteúdos baixos de IR e GLUT-4, sendo pouco responsivos ao estímulo com insulina. No entanto, com a ativação destes por imunomoduladores como a fitohemaglutinina (PHA), a expressão de IR é aumentada nestas células (BROWN;ERCOLANI;GINSBERG, 1983, 1985; et al., 1986). Estes achados são sugestivos de que a via de sinalização da insulina pode ser ativada na tentativa de proteger as células Jurkat contra o efeito apoptótico do PA. Resultados semelhantes foram encontrados em linfócitos humanos. A expressão de IR e GLUT-4 também mostrou correlação positiva com os resultados de fragmentação de DNA. Stentz e Kitabchi (2006) demonstraram que o PA induz expressão e translocação de IR e GLUT-4 para a membrana plasmática de linfócitos humanos e células de linhagem de aorta humanas (HAEC). As células HAEC são também pouco responsivas à insulina apresentando baixo conteúdo de IR e GLUT-4. No entanto, os autores deste trabalho utilizaram uma dose elevada de PA $(500 \mu \mathrm{M})$, tanto para células Jurkat como linfócitos humanos, o que pode induzir a morte destas células por necrose (LIMA et al., 2002; GORJAO et al., 2007). 
Em ratos com jejum de $48 \mathrm{~h}$ verificamos também aumento na morte de linfócitos, acompanhado por elevação da concentração de ácidos graxos circulantes. Na análise da composição dos AG no plasma foi encontrada aumento na porcentagem de AG saturados, principalmente palmítico e esteárico, correspondendo a $85 \%$ do total. Além disso, foi também observado aumento da abundância de IR e GLUT-4. Em estudo realizado por Pires et al (2007), foi também observada a morte de linfócitos de ratos em jejum e aumento da concentração de AGL, suportando a hipótese de que este cenário, encontrado em quadros de TD2M, por exemplo, podem levar a um impareamento da função imune.

O tratamento com PA aumentou a fosforilação de Akt. Esta observação é sugestiva de que este ácido graxo pode ativar uma via de sinalização alternativa que resulta na fosforilação de Akt como a via das PKC (BAUER et al., 2001; BAUER e BAIER, 2002). Sweeney et al (2004) observaram que a administração exógena de fosfatidil-inositol-trifosfato causa translocação de GLUT-4 do citossol para a membrana plasmática de células musculares e adiposas, mimetizando o efeito da insulina. Contudo, Russell et al (1999) reportaram aumento do conteúdo de GLUT-4 em músculo papilar ventricular de ratos, durante hipóxia induzida, que era independente da via da PI3K. Estes autores observaram aumento da atividade da AMPK e a administração de um agente ativador desta proteína, AICAR, estimulou a captação de glicose. Por outro lado, a administração de um inibidor de PI3K, a wortmanina, não afetou a translocação de GLUT-4 para a membrana plasmática.Estes resultados são sugestivos de que a translocação de GLUT-4 para a membrana plasmática pode ser ativada por vias e estímulos independente da sinalização da insulina.

Para verificar se o aumento na abundância de IR e GLUT-4 nas células Jurkat resultam em elevação do fluxo de substratos através da via glicolítica, a captação de glicose foi determinada. O consumo de glicose foi aumentado pelo tratamento com PA. A insulina não teve efeito adicional sobre a captação de glicose induzida pelo ácido graxo. A glicose é rapidamente utilizada em linfócitos para a geração de ATP e como fonte de carbono para a biossíntese de macromoléculas. A ativação de leucócitos está associada à utilização 
elevada de glicose visto que há aumento na expressão de transportadores de glicose (CALDER;DIMITRIADIS;NEWSHOLME, 2007). Em estudos relacionados ao tratamento de células Jurkat com anticorpos CD95, foi observada apoptose destas células devido à ativação do receptor da família do TNF (OEHM et al., 1992; et al., 1994) e diminuição da atividade dos transportadores de glicose (BERRIDGE et al., 1996).

Em adição aos resultados de elevação na captação de glicose, observase que a oxidação de glicose está diminuída e os esqueletos de carbonos estão sendo desviados para a produção de macromoléculas lipídicas como: triacilgliceróis, fosfolipídeos, ésteres de colesterol e ácidos graxos livres. A estimulação de vias biossintéticas à partir da glicose como precursora pode reduzir os efeitos tóxicos do PA. Os efeitos dos ácidos oleico e PA em ovários de hamster (LISTENBERGER et al., 2003), células de ilhotas pancreáticas (CNOP et al., 2001) e células de linhagem de hepatócitos HepG2 (RICCHI et al., 2009) foram comparadas. O ácido oleico apresentou citotoxidade mais baixa e sua incorporação em frações de triacilgliceróis foi mais efetiva. Tais resultados corroboram com a proposição de que a conversão de ácido graxo em triacilgliceróis pode reduzir sua toxicidade. No entanto, o mecanismo de proteção da célula é ineficiente quando quantidades excessivas do ácido graxo são administradas, excedendo-se a capacidade de incorporá-lo em triacilgliceróis.

A insulina e o metabolismo de glicose podem atuar na proteção contra a morte das células. lida et al (2002) observaram que a insulina pode proteger as células THP-1, células de linhagem humana monocítica, da apoptose induzida por depleção energética. A proteção destas células foi relacionada à regulação positiva da proteína anti-apoptótica BcL-xL. Muller et al (2006) demostraram que a insulina secretada por células MIN6, uma linhagem celular secretora de insulina, em resposta à glicose elevada no meio, exercem efeito autócrino para proteger a célula da apoptose e estimular a proliferação celular. Zhao et al (2008) observaram que a ativação da proteína pró-apoptótica Puma é metabolicamente regulada em linfócitos T. A privação de glicose nestas células ativa esta proteína. O aumento do metabolismo de glicose, por sua vez, 
suprime a sua atividade e atenua a morte celular após a retirada de fatores de crescimento do meio.

As células tratadas com PA apresentaram um aumento do consumo de glutamina e da produção de glutamato de forma dose-dependente à concentração de PA. Em linfócitos, juntamente com a glicose, o consumo de glutamina é elevado e a diminuição da sua disponibilidade compromete a proliferação celular (NEWSHOLME, 1996; CURI et al., 2005), síntese de citocinas como a IL-2 e IFN-Y (CHANG;YANG;SHAIO, 1999), diminuição da produção de marcadores de superfície como a CD25 e CD45, e da proporção de linfócitos $\mathrm{CD}^{+}$(YAQOOB e CALDER, 1996). Os principais produtos do metabolismo de glutamina são: glutamato, aspartato e glutamato, sendo que este último pode atuar como precurssor da síntese de GSH. Além disso a glutamina é importante na produção de ATP e portanto para as reações ATPdependentes da síntese de GSH (POMPELLA et al., 2003). Chang et al (2002) mostraram que a suplementação de glutamina pode proteger células Jurkat da apoptose induzida por PMA e ionomicina, um ionóforo para $\left[\mathrm{Ca}^{2+}\right]$, através do aumento do conteúdo de GSH e diminuição de ROS.

Apesar do aumento no consumo de glutamina e na produção de glutamato observa-se que as células tratadas com PA exibem diminuição da viabilidade celular, depleção de GSH e aumento de ROS de maneira dose dependente. Evidencia-se, portanto, que na estratégia de sobrevivência das células foi ineficiente frente ao efeito tóxico do PA.

O tratamento com PA ativou o NF-kB em células Jurkat no período de $2 \mathrm{~h}$. Por sua vez, o agente apoptótico estaurosporina não conseguiu ativá-lo no período de $2 \mathrm{~h}$. O NF-kB é um regulador da expressão de genes que controlam a proliferação e a sobrevivência de células eucariotas, além de participar na regulação da diferenciação de células $\mathrm{T}$, imunidade, resposta inflamatória, apoptose e metástase (PERKINS e GILMORE, 2006). O NF-kB regula a expressão de genes anti-apoptóticos como a TRAF1 e TRAF2 diminuindo a atividade de caspases (SHEIKH e HUANG, 2003). Em estudo realizado com células de pacientes com leucemia crônica de células $B$, o tratamento com TNF- $\alpha$ induz a proliferação destas células via ativação de NF-kB O uso da 
estaurosporina aboliu a ativação do NF-kB e portanto inibiu a proliferação celular (JABBAR;HOFFBRAND;WICKREMASINGHE, 1994). Guha et al (2007) demonstraram que em células de miócitos da linhagem C212 a interrupção no potencial de membrana mitocondrial, através da depleção do DNA mitocondrial ou o tratamento com o ionóforo mitocondrial CCCP (carbonyl-cyanide $\mathrm{m}$ chlorophenylhidrazone), causa estresse oxidativo que culmina em uma captação acentuada de glicose e da ativação da glicólise. Além disso, observaram aumento da expressão de GLUT-4 e receptores de insulina e IGF-1. Este mesmo grupo de pesquisadores confirmou que o aumento da expressão de IR, IGF-R e GLUT-4 está relacionado à ativação do NF-kB. Ensaios inibindo a ativação deste fator de transcrição levaram à diminuição da expressão destas proteínas e aumento do estresse oxidativo e de apoptose (BISWAS et al., 2008).

O tratamento das células Jurkat com os indutores de apoptose, estaurosporina e etoposide, apresentou resultados semelhantes aos ensaios realizados com PA. Estes indutores causaram apoptose das células e elevou a expressão de IR e GLUT-4 na membrana plasmática. Tais efeitos devem constituir uma tentativa das células de sobreviver frente ao efeito apoptótico da estaurosporina e do etoposide bem como do PA. 


\section{CONCLUSÃO}

O tratamento com PA induziu apoptose das células Jurkat de maneira tempo e dose dependente. Foi evidenciado que há ativação da via intrínseca de morte celular caracterizada pela liberação de citocromo c da mitocondria e ativação das caspases 3 e 9, além das vias induzidas pela JNK e p38 MAPK e produção de ROS. No entanto, concomitantemente, observamos que provavelmente como tentativa de sobrevivência, os linfócitos tratados com PA apresentam ativação das vias de sinalização da insulina, estimulando a captação de glicose e síntese de macromoléculas lipídicas (triacilgliceróis, fosfolípides e ésteres de colesterol) e, portanto, removendo o PA e inibindo o seu efeito citotóxico. Contudo, na presença de altas concentrações de PA prevalece o mecanismo de apoptose. 


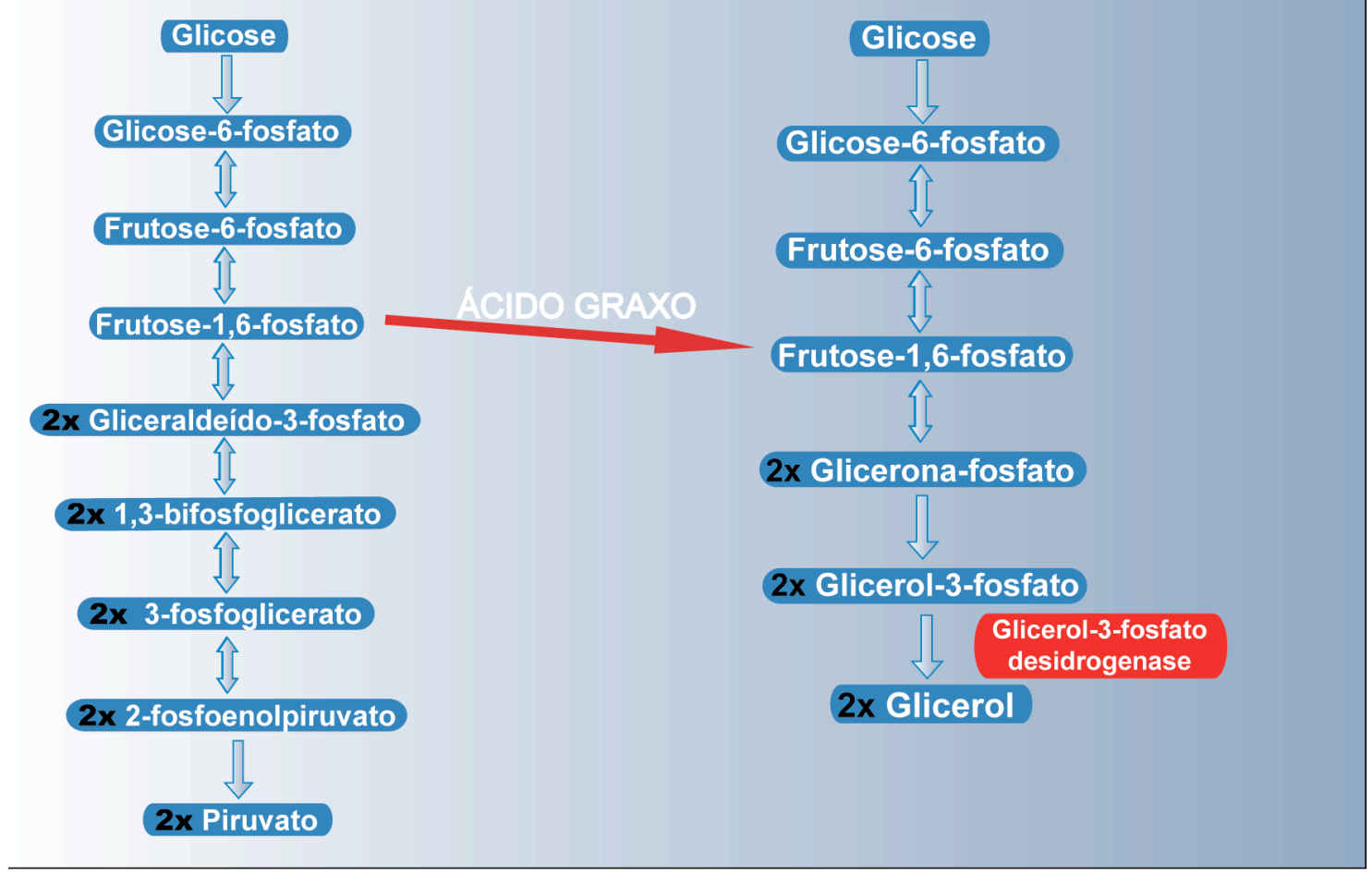

Figura 36 - Comparação entre a via glicolítica e a síntese de glicerol. O ácido graxo inibe a continuidade da via glicolítica e estimula a síntese de glicerol que é utilizado como esqueleto de carbono para a síntese de lípides como os triacilgliceróis e fosfolípides. 


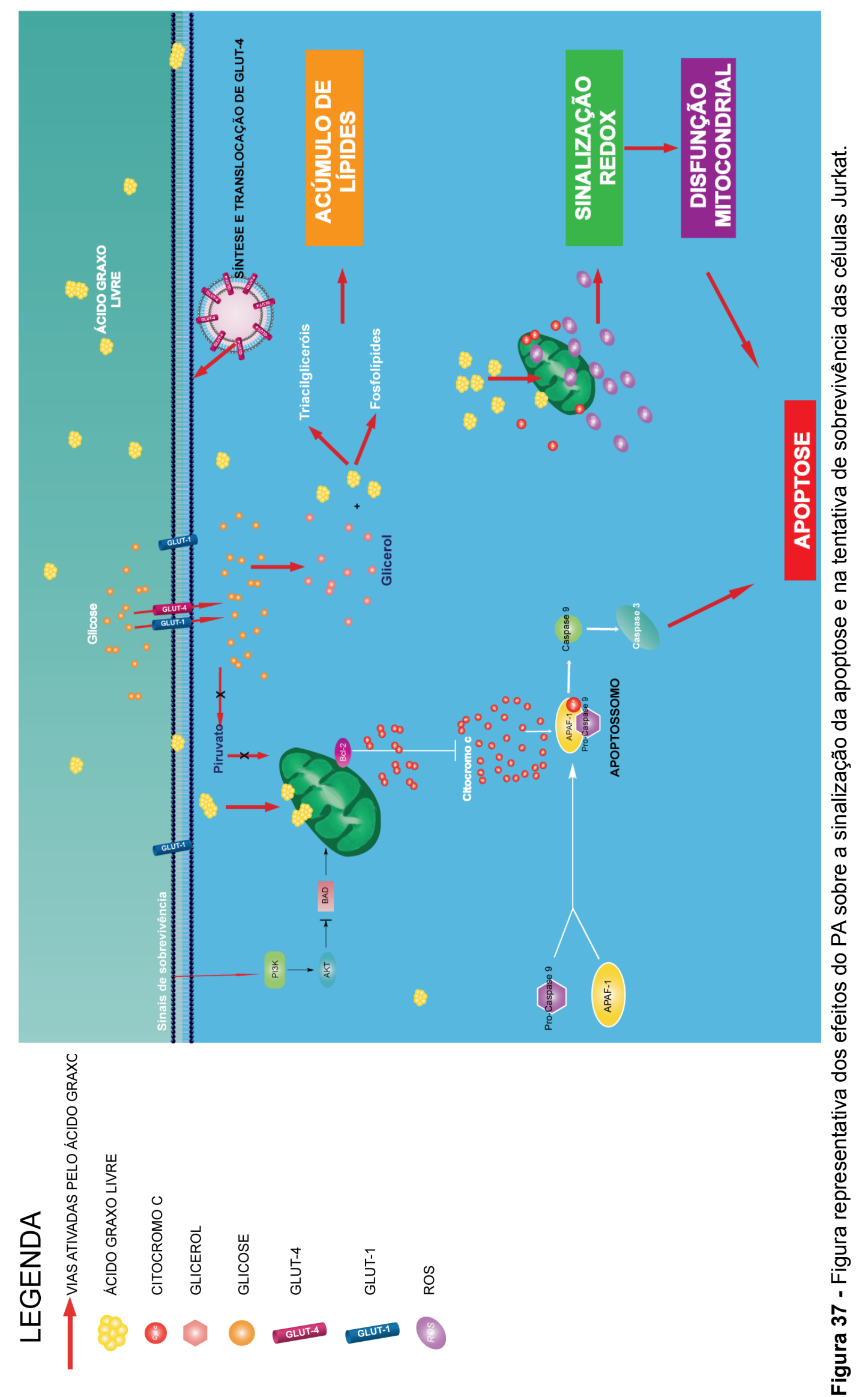




\section{REFERÊNCIAS 1}

ABARAVICIENE, S. M.; LUNDQUIST, I.; SALEHI, A. Rosiglitazone counteracts palmitate-induced beta-cell dysfunction by suppression of MAP kinase, inducible nitric oxide synthase and caspase 3 activities. Cell Mol. Life. Sci., v. 65, n. 14, p. 2256-65, 2008.

ADAMEC, E.; MOHAN, P. S.; CATALDO, A. M.; VONSATTEL, J. P.; NIXON, R. A. Up-regulation of the lysosomal system in experimental models of neuronal injury: implications for Alzheimer's disease. Neuroscience, v. 100, n. 3, p. 663-75, 2000.

AGGARWAL, B. B. Signalling pathways of the TNF superfamily: a doubleedged sword. Nat. Rev. Immunol., v. 3, n. 9, p. 745-56, 2003.

ALDERSON, M. R.; TOUGH, T. W.; BRADDY, S.; DAVIS-SMITH, T.; ROUX, E.; SCHOOLEY, K.; MILLER, R. E.; LYNCH, D. H. Regulation of apoptosis and T cell activation by Fas-specific mAb. Int. Immunol., v. 6, n. 11, p. 1799-806, 1994.

ANDERSON, M. K. At the crossroads: diverse roles of early thymocyte transcriptional regulators. Immunol. Rev., v. 209, p. 191-211, 2006.

ANDREWS, N. C.; FALLER, D. V. A rapid micropreparation technique for extraction of DNA-binding proteins from limiting numbers of mammalian cells. Nucleic Acids Res., v. 19, n. 9, p. 2499, 1991.

ANEL, A.; RICHIERI, G. V.; KLEINFELD, A. M. A tyrosine phosphorylation requirement for cytotoxic T lymphocyte degranulation. J. Biol. Chem., v. 269, n. 13, p. 9506-13, 1994.

ARDAWI, M. S.; NEWSHOLME, E. A. Glutamine metabolism in lymphocytes of the rat. Biochem. J., v. 212, n. 3, p. 835-42, 1983.

1De acordo com: ASSOCIAÇÃO BRASILEIRA DE NORMAS TÉCNICAS. NBR 6023: Informação e documentação: referências: elaboração. Rio de Janeiro, 2002. 
ATTARDI, L. D.; DEPINHO, R. A. Conquering the complexity of p53. Nat. Genet., v. 36, n. 1, p. 7-8, 2004.

AUESTAD, N.; INNIS, S. M. Dietary n-3 fatty acid restriction during gestation in rats: neuronal cell body and growth-cone fatty acids. Am. J. Clin. Nutr., v. 71, n. 1 Suppl, p. 312S-4S, 2000.

AZEVEDO-MARTINS, A. K.; CURI, R. Fatty acids decrease catalase activity in human leukaemia cell lines. Cell Biochem. Funct., v. 26, n. 1, p. 87-94, 2008.

BAEHRECKE, E. H. How death shapes life during development. Nat. Rev. Mol. Cell Biol., v. 3, n. 10, p. 779-87, 2002.

BANDOH, S.; TSUKADA, T.; MARUYAMA, K.; OHKURA, N.; YAMAGUCHI, K. Differential expression of NGFI-B and RNR-1 genes in various tissues and developing brain of the rat: comparative study by quantitative reverse transcription-polymerase chain reaction. J. Neuroendocrinol., v. 9, n. 1, p. 3-8, 1997.

BARVITENKO, N. N.; ADRAGNA, N. C.; WEBER, R. E. Erythrocyte signal transduction pathways, their oxygenation dependence and functional significance. Cell. Physiol. Biochem., v. 15, n. 1-4, p. 1-18, 2005.

BAUER, B.; BAIER, G. Protein kinase C and AKT/protein kinase B in CD4+ Tlymphocytes: new partners in TCR/CD28 signal integration. Mol. Immunol., v. 38, n. 15, p. 1087-99, 2002.

BAUER, B.; KRUMBOCK, N.; FRESSER, F.; HOCHHOLDINGER, F.; SPITALER, M.; SIMM, A.; UBERALL, F.; SCHRAVEN, B.; BAIER, G. Complex formation and cooperation of protein kinase $C$ theta and Akt1/protein kinase $B$ alpha in the NF-kappa B transactivation cascade in Jurkat T cells. J. Biol. Chem., v. 276, n. 34, p. 31627-34, 2001.

BENNETT, M.; MACDONALD, K.; CHAN, S. W.; LUZIO, J. P.; SIMARI, R.; WEISSBERG, P. Cell surface trafficking of Fas: a rapid mechanism of p53mediated apoptosis. Science, v. 282, n. 5387, p. 290-3, 1998. 
BERRIDGE, M. V.; TAN, A. S.; MCCOY, K. D.; KANSARA, M.; RUDERT, F. CD95 (Fas/Apo-1)-induced apoptosis results in loss of glucose transporter function. J. Immunol., v. 156, n. 11, p. 4092-9, 1996.

BIANCHI, M. E. Significant (re)location: how to use chromatin and/or abundant proteins as messages of life and death. Trends Cell. Biol., v. 14, n. 6, p. 287-93, 2004.

BISWAS, G.; TANG, W.; SONDHEIMER, N.; GUHA, M.; BANSAL, S.; AVADHANI, N. G. A distinctive physiological role for IkappaBbeta in the propagation of mitochondrial respiratory stress signaling. J. Biol. Chem., v. 283, n. 18, p. 12586-94, 2008.

BOSCA, L.; ZEINI, M.; TRAVES, P. G.; HORTELANO, S. Nitric oxide and cell viability in inflammatory cells: a role for $\mathrm{NO}$ in macrophage function and fate. Toxicol., v. 208, n. 2, p. 249-58, 2005.

BOSMAN, G. J.; WILLEKENS, F. L.; WERRE, J. M. Erythrocyte aging: a more than superficial resemblance to apoptosis? Cell Physiol. Biochem., v. 16, n. $1-3$, p. $1-8,2005$

BOUILLET, P.; STRASSER, A. Bax and Bak: back-bone of T cell death. Nat. Immunol., v. 3, n. 10, p. 893-4, 2002.

BRADFORD, M. M. A rapid and sensitive method for the quantitation of microgram quantities of protein utilizing the principle of protein-dye binding. Anal Biochem., v. 72, p. 248-54, 1976.

BRADLEY, J. R.; POBER, J. S. Tumor necrosis factor receptor-associated factors (TRAFs). Oncogene, v. 20, n. 44, p. 6482-91, 2001.

BRAY, S. J. Notch signalling: a simple pathway becomes complex. Nat. Rev. Mol. Cell Biol., v. 7, n. 9, p. 678-89, 2006.

BREITTMAYER, J. P.; PELASSY, C.; COUSIN, J. L.; BERNARD, A.; AUSSEL, $C$. The inhibition by fatty acids of receptor-mediated calcium movements in Jurkat T-cells is due to increased calcium extrusion. J. Biol. Chem., v. 268, n. 28, p. 20812-7, 1993. 
BRODIE, C.; BLUMBERG, P. M. Regulation of cell apoptosis by protein kinase C delta. Apoptosis, v. 8, n. 1, p. 19-27, 2003.

BROOKS, C. L.; GU, W. Dynamics in the p53-Mdm2 ubiquitination pathway. Cell Cycle, v. 3, n. 7, p. 895-9, 2004.

BROWN, T. J.; ERCOLANI, L.; GINSBERG, B. H. Properties and regulation of the T lymphocyte insulin receptor. J. Recept. Res., v. 3, n. 4, p. 481-94, 1983.

Demonstration of receptors for insulin-like growth factor-II on human Tlymphocytes. J. Recept. Res., v. 5, n. 4, p. 297-309, 1985.

BUFFINGTON, C. K.; EL-SHIEKH, T.; KITABCHI, A. E.; MATTERI, R. Phytohemagglutinin (PHA) activated human T-lymphocytes: concomitant appearance of insulin binding, degradation and insulin-mediated activation of pyruvate dehydrogenase (PDH). Biochem. Biophys. Res. Commun., v. 134, n. 1, p. 412-9, 1986.

CACICEDO, J. M.; BENJACHAREOWONG, S.; CHOU, E.; RUDERMAN, N. B.; IDO, Y. Palmitate-induced apoptosis in cultured bovine retinal pericytes: roles of $\mathrm{NAD}(\mathrm{P}) \mathrm{H}$ oxidase, oxidant stress, and ceramide. Diabetes, v. 54, n. 6, p. 1838-45, 2005.

CALDER, P. C. Fuel utilization by cells of the immune system. Proc. Nutr. Soc., v. 54, n. 1 , p. $65-82,1995$.

$\mathrm{N}-3$ polyunsaturated fatty acids and immune cell function. Adv. Enzyme Regul,. v. 37, p. 197-237, 1997.

CALDER, P. C.; DIMITRIADIS, G.; NEWSHOLME, P. Glucose metabolism in lymphoid and inflammatory cells and tissues. Curr. Opin. Clin. Nutr. Metab. Care, v. 10, n. 4, p. 531-40, 2007.

CALOGERO, S.; GRASSI, F.; AGUZZI, A.; VOIGTLANDER, T.; FERRIER, P.; FERRARI, S.; BIANCHI, M. E. The lack of chromosomal protein Hmg1 does not disrupt cell growth but causes lethal hypoglycaemia in newborn mice. Nat. Genet., v. 22, n. 3, p. 276-80, 1999. 
CASTRO-OBREGON, S.; RAO, R. V.; DEL RIO, G.; CHEN, S. F.; POKSAY, K. S.; RABIZADEH, S.; VESCE, S.; ZHANG, X. K.; SWANSON, R. A.; BREDESEN, D. E. Alternative, nonapoptotic programmed cell death: mediation by arrestin 2, ERK2, and Nur77. J. Biol. Chem., v. 279, n. 17, p. 17543-53, 2004.

CAUWELS, A.; JANSSEN, B.; WAEYTENS, A.; CUVELIER, C.; BROUCKAERT, $P$. Caspase inhibition causes hyperacute tumor necrosis factor-induced shock via oxidative stress and phospholipase A2. Nat. Immunol., v. 4, n. 4, p. 387-93, 2003.

CHANG, L.; KARIN, M. Mammalian MAP kinase signalling cascades. Nature, v. 410, n. 6824, p. 37-40, 2001.

CHANG, W. K.; YANG, K. D.; CHUANG, H.; JAN, J. T.; SHAIO, M. F. Glutamine protects activated human $T$ cells from apoptosis by up-regulating glutathione and Bcl-2 levels. Clin. Immunol., v. 104, n. 2, p. 151-60, 2002.

CHANG, W. K.; YANG, K. D.; SHAIO, M. F. Effect of glutamine on Th1 and Th2 cytokine responses of human peripheral blood mononuclear cells. Clin. Immunol., v. 93, n. 3, p. 294-301, 1999.

CHIANG, C. W.; HARRIS, G.; ELLIG, C.; MASTERS, S. C.; SUBRAMANIAN, R.; SHENOLIKAR, S.; WADZINSKI, B. E.; YANG, E. Protein phosphatase 2A activates the proapoptotic function of BAD in interleukin- 3-dependent lymphoid cells by a mechanism requiring 14-3-3 dissociation. Blood, v. 97, n. 5, p. 1289-97, 2001.

CHIANG, C. W.; KANIES, C.; KIM, K. W.; FANG, W. B.; PARKHURST, C.; XIE, M.; HENRY, T.; YANG, E. Protein phosphatase 2A dephosphorylation of phosphoserine 112 plays the gatekeeper role for BAD-mediated apoptosis. Mol. Cell. Biol., v. 23, n. 18, p. 6350-62, 2003.

CHIPUK, J. E.; BOUCHIER-HAYES, L.; GREEN, D. R. Mitochondrial outer membrane permeabilization during apoptosis: the innocent bystander scenario. Cell Death Differ., v. 13, n. 8, p. 1396-402, 2006. 
CHIRALA, S. S.; JAYAKUMAR, A.; GU, Z. W.; WAKIL, S. J. Human fatty acid synthase: role of interdomain in the formation of catalytically active synthase dimer. Proc. Natl. Acad. Sci. U S A, v. 98, n. 6, p. 3104-8, 2001.

CIOFANI, M.; ZUNIGA-PFLUCKER, J. C. Notch promotes survival of pre-T cells at the beta-selection checkpoint by regulating cellular metabolism. Nat .Immunol., v. 6, n. 9, p. 881-8, 2005.

CLAUDIO, E.; BROWN, K.; PARK, S.; WANG, H.; SIEBENLIST, U. BAFFinduced NEMO-independent processing of NF-kappa B2 in maturing B cells. Nat. Immunol,. v. 3, n. 10, p. 958-65, 2002.

CNOP, M.; HANNAERT, J. C.; HOORENS, A.; EIZIRIK, D. L.; PIPELEERS, D. $G$. Inverse relationship between cytotoxicity of free fatty acids in pancreatic islet cells and cellular triglyceride accumulation. Diabetes, v. 50, n. 8, p. 1771-7, 2001.

COHEN, G. M. Caspases: the executioners of apoptosis. Biochem. J., v. 326 ( Pt 1), p. 1-16, 1997.

COTTERMAN, R.; JIN, V. X.; KRIG, S. R.; LEMEN, J. M.; WEY, A.; FARNHAM, P. J.; KNOEPFLER, P. S. N-Myc regulates a widespread euchromatic program in the human genome partially independent of its role as a classical transcription factor. Cancer Res., v. 68, n. 23, p. 9654-62, 2008.

CRABTREE, B.; NEWSHOLME, E. A. A quantitative approach to metabolic control. Curr. Top. Cell. Regul., v. 25, p. 21-76, 1985.

CURI, R.; LAGRANHA, C. J.; DOI, S. Q.; SELLITTI, D. F.; PROCOPIO, J.; PITHON-CURI, T. C.; CORLESS, M.; NEWSHOLME, P. Molecular mechanisms of glutamine action. J. Cell. Physiol., v. 204, n. 2, p. 392-401, 2005.

CURI, R.; NEWSHOLME, P.; PITHON-CURI, T. C.; PIRES-DE-MELO, M.; GARCIA, C.; HOMEM-DE-BITTENCOURT JUNIOR, P. I.; GUIMARAES, A. R. Metabolic fate of glutamine in lymphocytes, macrophages and neutrophils.

Braz .J. Med. Biol. Res., v. 32, n. 1, p. 15-21, 1999. 
CURY-BOAVENTURA, M. F.; GORJAO, R.; DE LIMA, T. M.; NEWSHOLME, P.; CURI, R. Comparative toxicity of oleic and linoleic acid on human lymphocytes. Life. Sci., v. 78, n. 13, p. 1448-56, 2006.

CURY-BOAVENTURA, M. F.; POMPEIA, C.; CURI, R. Comparative toxicity of oleic acid and linoleic acid on Jurkat cells. Clin. Nutr., v. 23, n. 4, p. 721-32, 2004.

DAS, I.; CRAIG, C.; FUNAHASHI, Y.; JUNG, K. M.; KIM, T. W.; BYERS, R.; WENG, A. P.; KUTOK, J. L.; ASTER, J. C.; KITAJEWSKI, J. Notch oncoproteins depend on gamma-secretase/presenilin activity for processing and function. $\mathbf{J}$. Biol. Chem., v. 279, n. 29, p. 30771-80, 2004.

DATTA, S. R.; KATSOV, A.; HU, L.; PETROS, A.; FESIK, S. W.; YAFFE, M. B.; GREENBERG, M. E. 14-3-3 proteins and survival kinases cooperate to inactivate BAD by BH3 domain phosphorylation. Mol. Cell, v. 6, n. 1, p. 41-51, 2000.

DBAIBO, G. S.; HANNUN, Y. A. Signal transduction and the regulation of apoptosis: roles of ceramide. Apoptosis, v. 3, n. 5, p. 317-34, 1998.

DE BOTTON, S.; SABRI, S.; DAUGAS, E.; ZERMATI, Y.; GUIDOTTI, J. E.; HERMINE, O.; KROEMER, G.; VAINCHENKER, W.; DEBILI, N. Platelet formation is the consequence of caspase activation within megakaryocytes.

Blood, v. 100, n. 4, p. 1310-7, 2002.

DELEVE, L. D.; KAPLOWITZ, N. Glutathione metabolism and its role in hepatotoxicity. Pharmacol. Ther., v. 52, n. 3, p. 287-305, 1991.

DEVI, G. R. XIAP as target for therapeutic apoptosis in prostate cancer. Drug News Perspect., v. 17, n. 2, p. 127-34, 2004.

DEY, D.; MUKHERJEE, M.; BASU, D.; DATTA, M.; ROY, S. S.; BANDYOPADHYAY, A.; BHATTACHARYA, S. Inhibition of insulin receptor gene expression and insulin signaling by fatty acid: interplay of PKC isoforms therein. Cell Physiol. Biochem., v. 16, n. 4-6, p. 217-28, 2005. 
DIESSENBACHER, P.; HUPE, M.; SPRICK, M. R.; KERSTAN, A.; GESERICK, P.; HAAS, T. L.; WACHTER, T.; NEUMANN, M.; WALCZAK, H.; SILKE, J.; LEVERKUS, M. NF-kappaB inhibition reveals differential mechanisms of TNF versus TRAIL-induced apoptosis upstream or at the level of caspase-8 activation independent of clAP2. J. Invest. Dermato.I, v. 128, n. 5, p. 1134-47, 2008.

DLAMINI, Z.; MBITA, Z.; ZUNGU, M. Genealogy, expression, and molecular mechanisms in apoptosis. Pharmacol. Ther., v. 101, n. 1, p. 1-15, 2004.

DONG, Y. L.; YAN, T.; HERNDON, D. N.; WAYMACK, J. P. Alterations in intracellular lymphocyte metabolism induced by infection and injury. J. Surg. Res., v. 53, n. 3, p. 293-7, 1992.

ECKERT, A.; MARQUES, C. A.; KEIL, U.; SCHUSSEL, K.; MULLER, W. E. Increased apoptotic cell death in sporadic and genetic Alzheimer's disease. Ann. N. Y. Acad. Sci., v. 1010, p. 604-9, 2003.

EDINGER, A. L.; THOMPSON, C. B. Akt maintains cell size and survival by increasing mTOR-dependent nutrient uptake. Mol. Biol. Cell, v. 13, n. 7, p. 2276-88, 2002.

ENGEDAL, N.; SAATCIOGLU, F. Ceramide-induced cell death in the prostate cancer cell line LNCaP has both necrotic and apoptotic features. Prostate, v. 46, n. 4, p. 289-97, 2001.

ERKAN, M.; KLEEFF, J.; ESPOSITO, I.; GIESE, T.; KETTERER, K.; BUCHLER, M. W.; GIESE, N. A.; FRIESS, H. Loss of BNIP3 expression is a late event in pancreatic cancer contributing to chemoresistance and worsened prognosis. Oncogene, v. 24, n. 27, p. 4421-32, 2005.

ERLANDSSON HARRIS, H.; ANDERSSON, U. Mini-review: The nuclear protein HMGB1 as a proinflammatory mediator. Eur. J. Immunol., v. 34, n. 6, p. 1503-12, 2004.

FADEEL, B.; ORRENIUS, S. Apoptosis: a basic biological phenomenon with wide-ranging implications in human disease. J. Intern. Med., v. 258, n. 6, p. 479-517, 2005. 
FADOK, V. A. The sirens' call. Nat. Cell Biol., v. 5, n. 8, p. 697-9, 2003.

FADOK, V. A.; BRATTON, D. L.; ROSE, D. M.; PEARSON, A.; EZEKEWITZ, R. A.; HENSON, P. M. A receptor for phosphatidylserine-specific clearance of apoptotic cells. Nature, v. 405, n. 6782, p. 85-90, 2000.

FAS, S. C.; FRITZSCHING, B.; SURI-PAYER, E.; KRAMMER, P. H. Death receptor signaling and its function in the immune system. Curr. Dir. Autoimmun., v. 9, p. 1-17, 2006.

FENNELL, D. A.; PALLASKA, A.; CORBO, M.; COTTER, F. E. Stochastic modelling of apoptosis kinetics. Apoptosis, v. 10, n. 2, p. 447-52, 2005.

FERL, R. J. 14-3-3 proteins: regulation of signal-induced events. Physiol .Plant, v. 120, n. 2, p. 173-178, 2004.

FERRI, K. F.; KROEMER, G. Organelle-specific initiation of cell death pathways. Nat. Cell .Biol., v. 3, n. 11, p. E255-63, 2001.

FIUZA, U. M.; ARIAS, A. M. Cell and molecular biology of Notch. J. Endocrinol., v. 194, n. 3, p. 459-74, 2007.

FOGHSGAARD, L.; WISSING, D.; MAUCH, D.; LADEMANN, U.; BASTHOLM, L.; BOES, M.; ELLING, F.; LEIST, M.; JAATTELA, M. Cathepsin B acts as a dominant execution protease in tumor cell apoptosis induced by tumor necrosis factor. J. Cell. Biol,. v. 153, n. 5, p. 999-1010, 2001.

FOLCH, J.; LEES, M.; SLOANE STANLEY, G. H. A simple method for the isolation and purification of total lipides from animal tissues. J. Biol. Chem., v. 226, n. 1, p. 497-509, 1957.

FRANCO, R.; CIDLOWSKI, J. A. SLCO/OATP-like transport of glutathione in FasL-induced apoptosis: glutathione efflux is coupled to an organic anion exchange and is necessary for the progression of the execution phase of apoptosis. J. Biol. Chem., v. 281, n. 40, p. 29542-57, 2006. 
FRANCO, R.; PANAYIOTIDIS, M. I.; CIDLOWSKI, J. A. Glutathione depletion is necessary for apoptosis in lymphoid cells independent of reactive oxygen species formation. J. Biol. Chem., v. 282, n. 42, p. 30452-65, 2007.

GARRIDO, C.; GALLUZZI, L.; BRUNET, M.; PUIG, P. E.; DIDELOT, C.; KROEMER, G. Mechanisms of cytochrome c release from mitochondria. Cell Death Differ., v. 13, n. 9, p. 1423-33, 2006.

GEARHART, J.; PASHOS, E. E.; PRASAD, M. K. Pluripotency redux--advances in stem-cell research. N. Engl. J. Med., v. 357, n. 15, p. 1469-72, 2007.

GIBSON, R. A.; MAKRIDES, M. n-3 polyunsaturated fatty acid requirements of $t$ erm infants. Am. J. Clin. Nutr., v. 71, n. 1 Suppl, p. 251S-5S, 2000.

GLUCKSMANN, A. Local factors in the histogenesis of hypertrophic scars. Br. J. Plast. Surg., v. 4, n. 2, p. 88-103, 1951.

GORJAO, R.; CURY-BOAVENTURA, M. F.; DE LIMA, T. M.; CURI, R. Regulation of human lymphocyte proliferation by fatty acids. Cell Biochem. Funct., v. 25, n. 3, p. 305-15, 2007.

GOZUACIK, D.; KIMCHI, A. Autophagy as a cell death and tumor suppressor mechanism. Oncogene, v. 23, n. 16, p. 2891-906, 2004.

GREEN, D. R.; AMARANTE-MENDES, G. P. The point of no return: mitochondria, caspases, and the commitment to cell death. Results Probl. Cell Differ., v. 24, p. 45-61, 1998.

GUHA, M.; SRINIVASAN, S.; BISWAS, G.; AVADHANI, N. G. Activation of a novel calcineurin-mediated insulin-like growth factor-1 receptor pathway, altered metabolism, and tumor cell invasion in cells subjected to mitochondrial respiratory stress. J. Biol. Chem., v. 282, n. 19, p. 14536-46, 2007.

GUICCIARDI, M. E.; DEUSSING, J.; MIYOSHI, H.; BRONK, S. F.; SVINGEN, P. A.; PETERS, C.; KAUFMANN, S. H.; GORES, G. J. Cathepsin B contributes to TNF-alpha-mediated hepatocyte apoptosis by promoting mitochondrial release of cytochrome c. J. Clin. Invest., v. 106, n. 9, p. 1127-37, 2000. 
GUIMARAES, C. A.; BENCHIMOL, M.; AMARANTE-MENDES, G. P.; LINDEN, R. Alternative programs of cell death in developing retinal tissue. J. Biol. Chem., v. 278, n. 43, p. 41938-46, 2003.

HABER, E. P.; HIRABARA, S. M.; GOMES, A. D.; CURI, R.; CARPINELLI, A. R.; CARVALHO, C. R. Palmitate modulates the early steps of insulin signalling pathway in pancreatic islets. FEBS Lett., v. 544, n. 1-3, p. 185-8, 2003.

HALLIWELL, B.; GUTTERIDGE, J. M. C. Free radicals in biology and medicine. 3rd. Oxford New York: Clarendon Press; Oxford University Press, 1999. xxxi, 936 p. ISBN 0198500459 (Hbk) 0198500440 (Pbk).

HAMMOND, C. L.; MADEJCZYK, M. S.; BALLATORI, N. Activation of plasma membrane reduced glutathione transport in death receptor apoptosis of HepG2 cells. Toxicol. Appl. Pharmacol., v. 195, n. 1, p. 12-22, 2004.

HAYDAY, A. C.; PENNINGTON, D. J. Key factors in the organized chaos of early T cell development. Nat Immunol ., v. 8, n. 2, p. 137-44, 2007.

HENDRICKSON, S. C.; ST LOUIS, J. D.; LOWE, J. E.; ABDEL-ALEEM, S. Free fatty acid metabolism during myocardial ischemia and reperfusion. Mol. Cell Biochem., v. 166, n. 1-2, p. 85-94, 1997.

HENGARTNER, M. O. The biochemistry of apoptosis. Nature, v. 407, n. 6805 , p. $770-6,2000$.

HENRY-MOWATT, J.; DIVE, C.; MARTINOU, J. C.; JAMES, D. Role of mitochondrial membrane permeabilization in apoptosis and cancer. Oncogene, v. 23 , n. 16, p. $2850-60,2004$.

HENSON, P. M.; BRATTON, D. L.; FADOK, V. A. The phosphatidylserine receptor: a crucial molecular switch? Nat .Rev. Mol. Cell. Biol., v. 2, n. 8, p. 627-33, 2001.

HERCEG, Z.; WANG, Z. Q. Failure of poly(ADP-ribose) polymerase cleavage by caspases leads to induction of necrosis and enhanced apoptosis. Mol. Cell Biol., v. 19, n. 7, p. 5124-33, 1999. 
HERMEKING, H. The 14-3-3 cancer connection. Nat. Rev. Cancer, v. 3, n. 12, p. 931-43, 2003.

HIRAI, I.; WANG, H. G. Survival-factor-induced phosphorylation of Bad results in its dissociation from Bcl-x $(\mathrm{L})$ but not Bcl-2. Biochem. J., v. 359, n. Pt 2, p. 345-52, 2001.

HOFFMAN, B.; LIEBERMANN, D. A. The proto-oncogene c-myc and apoptosis. Oncogene, v. 17, n. 25, p. 3351-7, 1998.

HOLCIK, M.; GIBSON, H.; KORNELUK, R. G. XIAP: apoptotic brake and promising therapeutic target. Apoptosis, v. 6, n. 4, p. 253-61, 2001.

HOLCIK, M.; KORNELUK, R. G. XIAP, the guardian angel. Nat. Rev. Mol. Cell Biol., v. 2, n. 7, p. 550-6, 2001.

HOLLER, N.; ZARU, R.; MICHEAU, O.; THOME, M.; ATTINGER, A.; VALITUTTI, S.; BODMER, J. L.; SCHNEIDER, P.; SEED, B.; TSCHOPP, J. Fas triggers an alternative, caspase-8-independent cell death pathway using the kinase RIP as effector molecule. Nat. Immunol,. v. 1, n. 6, p. 489-95, 2000.

HONG, S. J.; DAWSON, T. M.; DAWSON, V. L. Nuclear and mitochondrial conversations in cell death: PARP-1 and AIF signaling. Trends Pharmacol. Sci., v. 25, n. 5, p. 259-64, 2004.

HOTCHKISS, R. S.; OSMON, S. B.; CHANG, K. C.; WAGNER, T. H.; COOPERSMITH, C. M.; KARL, I. E. Accelerated lymphocyte death in sepsis occurs by both the death receptor and mitochondrial pathways. J. Immunol., v. 174, n. 8, p. 5110-8, 2005.

HUANG, Y.; RICH, R. L.; MYSZKA, D. G.; WU, H. Requirement of both the second and third BIR domains for the relief of X-linked inhibitor of apoptosis protein (XIAP)-mediated caspase inhibition by Smac. J. Biol .Chem., v. 278, n. 49, p. 49517-22, 2003. 
HUME, D. A.; RADIK, J. L.; FERBER, E.; WEIDEMANN, M. J. Aerobic glycolysis and lymphocyte transformation. Biochem. J., v. 174, n. 3, p. 703-9, 1978.

IIDA, K. T.; SUZUKI, H.; SONE, H.; SHIMANO, H.; TOYOSHIMA, H.; YATOH, S.; ASANO, T.; OKUDA, Y.; YAMADA, N. Insulin inhibits apoptosis of macrophage cell line, THP-1 cells, via phosphatidylinositol-3-kinase-dependent pathway. Arterioscler. Thromb. Vasc. Biol., v. 22, n. 3, p. 380-6, 2002.

ISRAELS, L. G.; ISRAELS, E. D. Apoptosis. Stem Cells, v. 17, n. 5, p. 306-13, 1999.

JAATTELA, M.; TSCHOPP, J. Caspase-independent cell death in T lymphocytes. Nat. Immunol., v. 4, n. 5, p. 416-23, 2003.

JABBAR, S. A.; HOFFBRAND, A. V.; WICKREMASINGHE, R. G. Redox reagents and staurosporine inhibit stimulation of the transcription regulator NFkappa B following tumour necrosis factor treatment of chronic B-leukaemia cells. Leuk. Res., v. 18, n. 7, p. 523-30, 1994.

JACOBSON, M. D.; RAFF, M. C. Programmed cell death and Bcl-2 protection in very low oxygen. Nature, v. 374, n. 6525, p. 814-6, 1995.

JIN, Z.; GAO, F.; FLAGG, T.; DENG, X. Nicotine induces multi-site phosphorylation of Bad in association with suppression of apoptosis. J. Biol. Chem., v. 279, n. 22, p. 23837-44, 2004.

JOAQUIN, A. M.; GOLLAPUDI, S. Functional decline in aging and disease: a role for apoptosis. J. Am. Geriatr. Soc., v. 49, n. 9, p. 1234-40, 2001.

JOSHI, I.; MINTER, L. M.; TELFER, J.; DEMAREST, R. M.; CAPOBIANCO, A. J.; ASTER, J. C.; SICINSKI, P.; FAUQ, A.; GOLDE, T. E.; OSBORNE, B. A. Notch signaling mediates G1/S cell-cycle progression in T cells via cyclin D3 and its dependent kinases. Blood, v. 113, n. 8, p. 1689-98, 2009. 
KARIN, M.; LIN, A. NF-kappaB at the crossroads of life and death. Nat. Immunol, v. 3, n. 3, p. 221-7, 2002.

KAUFMANN, S. H.; HENGARTNER, M. O. Programmed cell death: alive and well in the new millennium. Trends Cell. Biol., v. 11, n. 12, p. 526-34, 2001.

KERR, J. F.; WYLLIE, A. H.; CURRIE, A. R. Apoptosis: a basic biological phenomenon with wide-ranging implications in tissue kinetics. Br. J. Cancer, v. 26 , n. 4, p. 239-57, 1972.

KIANG, J. G.; KRISHNAN, S.; LU, X.; LI, Y. Inhibition of inducible nitric-oxide synthase protects human $\mathrm{T}$ cells from hypoxia-induced apoptosis. Mol. Pharmacol., v. 73, n. 3, p. 738-47, 2008.

KIM, J. E.; KIM, Y. W.; LEE, I. K.; KIM, J. Y.; KANG, Y. J.; PARK, S. Y. AMPactivated protein kinase activation by 5 -aminoimidazole-4-carboxamide-1-betaD-ribofuranoside (AICAR) inhibits palmitate-induced endothelial cell apoptosis through reactive oxygen species suppression. J. Pharmacol. Sci., v. 106, n. 3, p. 394-403, 2008.

KIM, J. W.; WON, J.; SOHN, S.; JOE, C. O. DNA-binding activity of the Nterminal cleavage product of poly(ADP-ribose) polymerase is required for UV mediated apoptosis. J. Cell. Sci., v. 113 ( Pt 6), p. 955-61, 2000.

KLEFSTROM, J.; ARIGHI, E.; LITTLEWOOD, T.; JAATTELA, M.; SAKSELA, E.; EVAN, G. I.; ALITALO, K. Induction of TNF-sensitive cellular phenotype by cMyc involves p53 and impaired NF-kappaB activation. EMBO J., v. 16, n. 24, p. 7382-92, 1997.

KORSHUNOV, S. S.; KORKINA, O. V.; RUUGE, E. K.; SKULACHEV, V. P.; STARKOV, A. A. Fatty acids as natural uncouplers preventing generation of O2.- and $\mathrm{H} 2 \mathrm{O} 2$ by mitochondria in the resting state. FEBS Lett., v. 435, n. 2-3, p. 215-8, 1998.

KOVACIC, S.; SOLTYS, C. L.; BARR, A. J.; SHIOJIMA, I.; WALSH, K.; DYCK, J. R. Akt activity negatively regulates phosphorylation of AMP-activated protein kinase in the heart. J Biol Chem, v. 278, n. 41, p. 39422-7, 2003. 
KRAUSS, S. W.; LO, A. J.; SHORT, S. A.; KOURY, M. J.; MOHANDAS, N.; CHASIS, J. A. Nuclear substructure reorganization during late-stage erythropoiesis is selective and does not involve caspase cleavage of major nuclear substructural proteins. Blood, v. 106, n. 6, p. 2200-5, 2005.

KROEMER, G.; DALLAPORTA, B.; RESCHE-RIGON, M. The mitochondrial death/life regulator in apoptosis and necrosis. Annu. Rev. Physiol,. v. 60, p. 619-42, 1998.

KUKIDOME, D.; NISHIKAWA, T.; SONODA, K.; IMOTO, K.; FUJISAWA, K.; YANO, M.; MOTOSHIMA, H.; TAGUCHI, T.; MATSUMURA, T.; ARAKI, E. Activation of AMP-activated protein kinase reduces hyperglycemia-induced mitochondrial reactive oxygen species production and promotes mitochondrial biogenesis in human umbilical vein endothelial cells. Diabetes, v. 55, n. 1, p. 120-7, 2006.

KUMAR, A.; TAKADA, Y.; BORIEK, A. M.; AGGARWAL, B. B. Nuclear factorkappaB: its role in health and disease. J. Mol. Med., v. 82, n. 7, p. 434-48, 2004.

LAEMMLI, U. K. Cleavage of structural proteins during the assembly of the head of bacteriophage T4. Nature, v. 227, n. 5259, p. 680-5, 1970.

LAI, E. C. Notch signaling: control of cell communication and cell fate. Development, v. 131, n. 5, p. 965-73, 2004.

LAMBERTUCCI, R. H.; HIRABARA, S. M.; SILVEIRA LDOS, R.; LEVADAPIRES, A. C.; CURI, R.; PITHON-CURI, T. C. Palmitate increases superoxide production through mitochondrial electron transport chain and NADPH oxidase activity in skeletal muscle cells. J. Cell. Physiol., v. 216, n. 3, p. 796-804, 2008.

LANG, F.; FOLLER, M.; LANG, K. S.; LANG, P. A.; RITTER, M.; GULBINS, E.; VERENINOV, A.; HUBER, S. M. Ion channels in cell proliferation and apoptotic cell death. J. Membr. Biol., v. 205, n. 3, p. 147-57, 2005.

LEE, S. H.; PARK, S. W.; PYO, C. W.; YOO, N. K.; KIM, J.; CHOI, S. Y. Requirement of the JNK-associated Bcl-2 pathway for human lactoferrininduced apoptosis in the Jurkat leukemia T cell line. Biochimie, v. 91, n. 1, p. 102-8, 2009. 
LEGASPI, A.; JEEVANANDAM, M.; STARNES, H. F., JR.; BRENNAN, M. F. Whole body lipid and energy metabolism in the cancer patient. Metabolism, $\mathrm{v}$. 36 , n. 10, p. 958-63, 1987.

LEIST, M.; JAATTELA, M. Four deaths and a funeral: from caspases to alternative mechanisms. Nat. Rev. Mol. Cell Biol., v. 2, n. 8, p. 589-98, 2001.

LEU, J. I.; DUMONT, P.; HAFEY, M.; MURPHY, M. E.; GEORGE, D. L. Mitochondrial p53 activates Bak and causes disruption of a Bak-Mcl1 complex. Nat. Cell Biol., v. 6, n. 5, p. 443-50, 2004.

LEVINE, B.; KLIONSKY, D. J. Development by self-digestion: molecular mechanisms and biological functions of autophagy. Dev. Cell, v. 6, n. 4, p. 463-77, 2004.

LI, Q.; VERMA, I. M. NF-kappaB regulation in the immune system. Nat. Rev. Immunol., v. 2, n. 10, p. 725-34, 2002.

LIMA, T. M.; KANUNFRE, C. C.; POMPEIA, C.; VERLENGIA, R.; CURI, R. Ranking the toxicity of fatty acids on Jurkat and Raji cells by flow cytometric analysis. Toxicol. In Vitro, v. 16, n. 6, p. 741-7, 2002.

LIN, B.; KOLLURI, S. K.; LIN, F.; LIU, W.; HAN, Y. H.; CAO, X.; DAWSON, M. I.; REED, J. C.; ZHANG, X. K. Conversion of Bcl-2 from protector to killer by interaction with nuclear orphan receptor Nur77/TR3. Cell, v. 116, n. 4, p. 527-40, 2004.

LISTENBERGER, L. L.; HAN, X.; LEWIS, S. E.; CASES, S.; FARESE, R. V., JR.; ORY, D. S.; SCHAFFER, J. E. Triglyceride accumulation protects against fatty acid-induced lipotoxicity. Proc. Natl .Acad. Sci. U. S. A., v. 100, n. 6, p. 3077-82, 2003.

LIU, Z. G.; BASKARAN, R.; LEA-CHOU, E. T.; WOOD, L. D.; CHEN, Y.; KARIN, M.; WANG, J. Y. Three distinct signalling responses by murine fibroblasts to genotoxic stress. Nature, v. 384, n. 6606, p. 273-6, 1996. 
LIZARD, G.; MONIER, S.; CORDELET, C.; GESQUIERE, L.; DECKERT, V.; GUELDRY, S.; LAGROST, L.; GAMBERT, P. Characterization and comparison of the mode of cell death, apoptosis versus necrosis, induced by 7 betahydroxycholesterol and 7-ketocholesterol in the cells of the vascular wall. Arterioscler. Thromb. Vasc. Biol., v. 19, n. 5, p. 1190-200, 1999.

LOCKSHIN, R. A.; ZAKERI, Z. Caspase-independent cell deaths. Curr. Opin. Cell Biol., v. 14, n. 6, p. 727-33, 2002.

LOCKSLEY, R. M.; KILLEEN, N.; LENARDO, M. J. The TNF and TNF receptor superfamilies: integrating mammalian biology. Cell, v. 104, n. 4, p. 487-501, 2001.

LU, Z. H.; MU, Y. M.; WANG, B. A.; LI, X. L.; LU, J. M.; LI, J. Y.; PAN, C. Y.; YANASE, T.; NAWATA, H. Saturated free fatty acids, palmitic acid and stearic acid, induce apoptosis by stimulation of ceramide generation in rat testicular Leydig cell. Biochem. Biophys. Re.s Commun., v. 303, n. 4, p. 1002-7, 2003.

MACK, A.; HACKER, G. Inhibition of caspase or FADD function blocks proliferation but not MAP kinase-activation and interleukin-2-production during primary stimulation of T cells. Eur .J .Immunol,. v. 32, n. 7, p. 1986-92, 2002.

MACKINTOSH, C. Dynamic interactions between 14-3-3 proteins and phosphoproteins regulate diverse cellular processes. Biochem. J., v. $381, \mathrm{n} . \mathrm{Pt}$ 2, p. 329-42, 2004.

MAJUMDER, P. K.; PANDEY, P.; SUN, X.; CHENG, K.; DATTA, R.; SAXENA, S.; KHARBANDA, S.; KUFE, D. Mitochondrial translocation of protein kinase $C$ delta in phorbol ester-induced cytochrome $\mathrm{c}$ release and apoptosis. J. Biol. Chem., v. 275, n. 29, p. 21793-6, 2000.

MAK, T. W.; YEH, W. C. Signaling for survival and apoptosis in the immune system. Arthritis. Res., v. 4 Suppl 3, p. S243-52, 2002.

MARTIN, S. J.; FINUCANE, D. M.; AMARANTE-MENDES, G. P.; O'BRIEN, G. A.; GREEN, D. R. Phosphatidylserine externalization during CD95-induced 
apoptosis of cells and cytoplasts requires ICE/CED-3 protease activity. J. Biol. Chem., v. 271, n. 46, p. 28753-6, 1996.

MARTINS DE LIMA, T.; GORJAO, R.; HATANAKA, E.; CURY-BOAVENTURA, M. F.; PORTIOLI SILVA, E. P.; PROCOPIO, J.; CURI, R. Mechanisms by which fatty acids regulate leucocyte function. Clin. Sci. (Lond)., v. 113, n. 2, p. 65-77, 2007.

MARUYAMA, K.; TSUKADA, T.; BANDOH, S.; SASAKI, K.; OHKURA, N.; YAMAGUCHI, K. Expression of the putative transcription factor NOR-1 in the nervous, the endocrine and the immune systems and the developing brain of the rat. Neuroendocrinology, v. 65, n. 1, p. 2-8, 1997.

MASSAO HIRABARA, S.; DE OLIVEIRA CARVALHO, C. R.; MENDONCA, J. R.; PILTCHER HABER, E.; FERNANDES, L. C.; CURI, R. Palmitate acutely raises glycogen synthesis in rat soleus muscle by a mechanism that requires its metabolization (Randle cycle). FEBS. Lett, v. 541, n. 1-3, p. 109-14, 2003.

MEBRATU, Y.; TESFAIGZI, Y. How ERK1/2 activation controls cell proliferation and cell death: Is subcellular localization the answer? Cell Cycle, v. 8, n. 8, p. 1168-75, 2009.

MEILHAC, O.; ESCARGUEIL-BLANC, I.; THIERS, J. C.; SALVAYRE, R.; NEGRE-SALVAYRE, A. Bcl-2 alters the balance between apoptosis and necrosis, but does not prevent cell death induced by oxidized low density lipoproteins. FASEB J., v. 13, n. 3, p. 485-94, 1999.

MELOCHE, S.; POUYSSEGUR, J. The ERK1/2 mitogen-activated protein kinase pathway as a master regulator of the G1- to S-phase transition. Oncogene, v. 26, n. 22, p. 3227-39, 2007.

MERRILL, A. H., JR. De novo sphingolipid biosynthesis: a necessary, but dangerous, pathway. J. Biol. Chem., v. 277, n. 29, p. 25843-6, 2002.

MINAMIKAWA, T.; WILLIAMS, D. A.; BOWSER, D. N.; NAGLEY, P. Mitochondrial permeability transition and swelling can occur reversibly without 
inducing cell death in intact human cells. Exp. Cell Res., v. 246, n. 1, p. 26-37, 1999.

MOCHIZUKI, T.; ASAI, A.; SAITO, N.; TANAKA, S.; KATAGIRI, H.; ASANO, T.; NAKANE, M.; TAMURA, A.; KUCHINO, Y.; KITANAKA, C.; KIRINO, T. Akt protein kinase inhibits non-apoptotic programmed cell death induced by ceramide. J. Biol. Chem., v. 277, n. 4, p. 2790-7, 2002.

MONCADA, S.; ERUSALIMSKY, J. D. Does nitric oxide modulate mitochondrial energy generation and apoptosis? Nat. Rev. Mol. Cell Biol., v. 3, n. 3, p. 214-20, 2002.

MULLER, D.; JONES, P. M.; PERSAUD, S. J. Autocrine anti-apoptotic and proliferative effects of insulin in pancreatic beta-cells. FEBS Lett., v. 580, n. 30, p. 6977-80, 2006.

NEWMEYER, D. D.; FERGUSON-MILLER, S. Mitochondria: releasing power for life and unleashing the machineries of death. Cell, v. 112, n. 4, p. 481-90, 2003.

NEWSHOLME, E. A. The possible role of glutamine in some cells of the immune system and the possible consequence for the whole animal. Experientia, v. 52, n. 5, p. 455-9, 1996.

NEWSHOLME, E. A.; DIMITRIADIS, G. The role of the lymphoid system in the regulation of the blood glucose level. Horm. Metab. Res., v. 39, n. 10, p. 730-3, 2007.

NEWSHOLME, P. Why is L-glutamine metabolism important to cells of the immune system in health, postinjury, surgery or infection? J. Nutr., v. 131, n. 9 Suppl, p. 2515S-22S; discussion 2523S-4S, 2001.

NEWSHOLME, P.; COSTA ROSA, L. F.; NEWSHOLME, E. A.; CURI, R. The importance of fuel metabolism to macrophage function. Cell Biochem. Funct., v. 14, n. 1, p. 1-10, 1996.

NICOLETTI, I.; MIGLIORATI, G.; PAGLIACCI, M. C.; GRIGNANI, F.; RICCARDI, C. A rapid and simple method for measuring thymocyte apoptosis 
by propidium iodide staining and flow cytometry. J. Immunol. Methods., v. 139, n. 2, p. 271-9, 1991.

NICOTERA, P.; LEIST, M.; MANZO, L. Neuronal cell death: a demise with different shapes. Trends. Pharmacol. Sci., v. 20, n. 2, p. 46-51, 1999.

NISHIHARA, H.; KIZAKA-KONDOH, S.; INSEL, P. A.; ECKMANN, L. Inhibition of apoptosis in normal and transformed intestinal epithelial cells by cAMP through induction of inhibitor of apoptosis protein (IAP)-2. Proc. Natl. Acad. Sci. U. S. A., v. 100, n. 15, p. 8921-6, 2003.

NONNECKE, B. J.; FRANKLIN, S. T.; YOUNG, J. W. Effects of ketones, acetate, and glucose on in vitro immunoglobulin secretion by bovine lymphocytes. J. Dairy. Sci., v. 75, n. 4, p. 982-90, 1992.

ODA, T.; ELKAHLOUN, A. G.; PIKE, B. L.; OKAJIMA, K.; KRANTZ, I. D.; GENIN, A.; PICCOLI, D. A.; MELTZER, P. S.; SPINNER, N. B.; COLLINS, F. S.; CHANDRASEKHARAPPA, S. C. Mutations in the human Jagged1 gene are responsible for Alagille syndrome. Nat. Genet., v. 16, n. 3, p. 235-42, 1997.

OEHM, A.; BEHRMANN, I.; FALK, W.; PAWLITA, M.; MAIER, G.; KLAS, C.; LIWEBER, M.; RICHARDS, S.; DHEIN, J.; TRAUTH, B. C.; ET AL. Purification and molecular cloning of the APO-1 cell surface antigen, a member of the tumor necrosis factor/nerve growth factor receptor superfamily. Sequence identity with the Fas antigen. J. Biol. Chem., v. 267, n. 15, p. 10709-15, 1992.

OGINO, T.; OZAKI, M.; HOSAKO, M.; OMORI, M.; OKADA, S.; MATSUKAWA, A. Activation of c-Jun N-terminal kinase is essential for oxidative stress-induced Jurkat cell apoptosis by monochloramine. Leuk. Res., v. 33, n. 1, p. 151-8, 2009.

OHTSUKA, T.; RYU, H.; MINAMISHIMA, Y. A.; MACIP, S.; SAGARA, J.; NAKAYAMA, K. I.; AARONSON, S. A.; LEE, S. W. ASC is .a Bax. adaptor and regulates the p53-Bax mitochondrial apoptosis pathway. Nat. Cell. Biol., v. 6, n. 2, p. 121-8, 2004. 
OPFERMAN, J. T.; KORSMEYER, S. J. Apoptosis in the development and maintenance of the immune system. Nat. Immunol., v. 4, n. 5, p. 410-5, 2003.

PARRY, R. V.; REIF, K.; SMITH, G.; SANSOM, D. M.; HEMMINGS, B. A.; WARD, S. G. Ligation of the T cell co-stimulatory receptor CD28 activates the serine-threonine protein kinase protein kinase B. Eur. J. Immunol., v. 27, n. 10, p. 2495-501, 1997.

PASINI, E.; CECONI, C.; CURELLO, S.; CARGNONI, A.; FERRARI, R. [Toxicity of fatty acids during myocardial reperfusion: a new possible mechanism of action]. Cardiologia, v. 36, n. 3, p. 237-45, 1991.

PASTORE, A.; FEDERICI, G.; BERTINI, E.; PIEMONTE, F. Analysis of glutathione: implication in redox and detoxification. Clin. Chim. Acta, v. 333, n. 1, p. 19-39, 2003.

PATTERSON, S. D.; SPAHR, C. S.; DAUGAS, E.; SUSIN, S. A.; IRINOPOULOU, T.; KOEHLER, C.; KROEMER, G. Mass spectrometric identification of proteins released from mitochondria undergoing permeability transition. Cell Death Diffe.r, v. 7, n. 2, p. 137-44, 2000.

PEARSON, G.; ROBINSON, F.; BEERS GIBSON, T.; XU, B. E.; KARANDIKAR, M.; BERMAN, K.; COBB, M. H. Mitogen-activated protein (MAP) kinase pathways: regulation and physiological functions. Endocr. Rev., v. 22, n. 2, p. 153-83, 2001.

PELENGARIS, S.; KHAN, M.; EVAN, G. c-MYC: more than just a matter of life and death. Nat. Rev. Cancer, v. 2, n. 10, p. 764-76, 2002.

PERFETTINI, J. L.; KROEMER, R. T.; KROEMER, G. Fatal liaisons of p53 with Bax and Bak. Nat. Cell. Biol., v. 6, n. 5, p. 386-8, 2004.

PERFETTINI, J. L.; REED, J. C.; ISRAEL, N.; MARTINOU, J. C.; DAUTRYVARSAT, A.; OJCIUS, D. M. Role of Bcl-2 family members in caspaseindependent apoptosis during Chlamydia infection. Infect. Immun., v. 70, n. 1, p. 55-61, 2002. 
PERKINS, N. D.; GILMORE, T. D. Good cop, bad cop: the different faces of NFkappaB. Cell Death Differ., v. 13, n. 5, p. 759-72, 2006.

PERL, M.; CHUNG, C. S.; AYALA, A. Apoptosis. Crit. Care. Med., v. 33, n. 12 Suppl, p. S526-9, 2005.

PIRES, J.; CURI, R.; OTTON, R. Induction of apoptosis in rat lymphocytes by starvation. Clin. Sci. (Lond)., v. 112, n. 1, p. 59-67, 2007.

PLAS, D. R.; RATHMELL, J. C.; THOMPSON, C. B. Homeostatic control of lymphocyte survival: potential origins and implications. Nat. Immunol., v. 3, n. 6, p. 515-21, 2002.

POMPELLA, A.; VISVIKIS, A.; PAOLICCHI, A.; DE TATA, V.; CASINI, A. F. The changing faces of glutathione, a cellular protagonist. Biochem. Pharmacol., $v$. 66, n. 8, p. 1499-503, 2003.

POZUELO RUBIO, M.; GERAGHTY, K. M.; WONG, B. H.; WOOD, N. T.; CAMPBELL, D. G.; MORRICE, N.; MACKINTOSH, C. 14-3-3-affinity purification of over 200 human phosphoproteins reveals new links to regulation of cellular metabolism, proliferation and trafficking. Biochem. J., v. 379, n. Pt 2, p. 395-408, 2004.

PRICE, D. L.; SISODIA, S. S.; BORCHELT, D. R. Genetic neurodegenerative diseases: the human illness and transgenic models. Science, v. 282, n. 5391, p. 1079-83, 1998.

PROSKURYAKOV, S. Y.; KONOPLYANNIKOV, A. G.; GABAI, V. L. Necrosis: a specific form of programmed cell death? Exp. Cell. Res., v. 283, n. 1, p. 1-16, 2003.

PUI, J. C.; ALLMAN, D.; XU, L.; DEROCCO, S.; KARNELL, F. G.; BAKKOUR, S.; LEE, J. Y.; KADESCH, T.; HARDY, R. R.; ASTER, J. C.; PEAR, W. S. Notch1 expression in early lymphopoiesis influences $B$ versus $T$ lineage determination. Immunity., v. 11, n. 3, p. 299-308, 1999. 
RAHMAN, I.; KODE, A.; BISWAS, S. K. Assay for quantitative determination of glutathione and glutathione disulfide levels using enzymatic recycling method. Nat. Protoc., v. 1, n. 6, p. 3159-65, 2006.

RANDLE, P. J.; GARLAND, P. B.; HALES, C. N.; NEWSHOLME, E. A. The glucose fatty-acid cycle. Its role in insulin sensitivity and the metabolic disturbances of diabetes mellitus. Lancet, v. 1, n. 7285, p. 785-9, 1963.

RATHMELL, J. C.; FARKASH, E. A.; GAO, W.; THOMPSON, C. B. IL-7 enhances the survival and maintains the size of naive T cells. J. Immunol., v. 167, n. 12, p. 6869-76, 2001.

RATHMELL, J. C.; THOMPSON, C. B. Pathways of apoptosis in lymphocyte development, homeostasis, and disease. Cell, v. 109 Suppl, p. S97-107, 2002. RATHMELL, J. C.; VANDER HEIDEN, M. G.; HARRIS, M. H.; FRAUWIRTH, K. A.; THOMPSON, C. B. In the absence of extrinsic signals, nutrient utilization by lymphocytes is insufficient to maintain either cell size or viability. Mol. Cell., v. 6, n. 3, p. 683-92, 2000.

REAVEN, G. M.; HOLLENBECK, C.; JENG, C. Y.; WU, M. S.; CHEN, Y. D. Measurement of plasma glucose, free fatty acid, lactate, and insulin for $24 \mathrm{~h}$ in patients with NIDDM. Diabetes, v. 37, n. 8, p. 1020-4, 1988.

RICCHI, M.; ODOARDI, M. R.; CARULLI, L.; ANZIVINO, C.; BALLESTRI, S.; PINETTI, A.; FANTONI, L. I.; MARRA, F.; BERTOLOTTI, M.; BANNI, S.; LONARDO, A.; CARULLI, N.; LORIA, P. Differential effect of oleic and palmitic acid on lipid accumulation and apoptosis in cultured hepatocytes. J. Gastroenterol. Hepatol., 2009.

RICE, L.; ALFREY, C. P. The negative regulation of red cell mass by neocytolysis: physiologic and pathophysiologic manifestations. Cell Physiol. Biochem., v. 15, n. 6, p. 245-50, 2005.

RICHIERI, G. V.; KLEINFELD, A. M. Free fatty acid perturbation of transmembrane signaling in cytotoxic T lymphocytes. J. Immunol., v. 143, n. 7, p. 2302-10, 1989.

Unbound free fatty acid levels in human serum. J. Lipid Res., v. 36, n. 2, p. 229-40, 1995. 
ROITT, I. Lymphoreticular system: functional organization. J. Clin. Pathol., v. 25, n. 11, p. 1003-4, 1972.

ROTHENBERG, E. V.; MOORE, J. E.; YUI, M. A. Launching the T-cell-lineage developmental programme. Na.t Rev. Immunol., v. 8, n. 1, p. 9-21, 2008.

RUSSELL, R. R., 3RD; BERGERON, R.; SHULMAN, G. I.; YOUNG, L. H. Translocation of myocardial GLUT-4 and increased glucose uptake through activation of AMPK by AICAR. Am. J. Physiol., v. 277, n. 2 Pt 2, p. H643-9, 1999.

RUTTER, G. A.; DA SILVA XAVIER, G.; LECLERC, I. Roles of 5'-AMP-activated protein kinase (AMPK) in mammalian glucose homoeostasis. Biochem. J., v. 375, n. Pt 1, p. 1-16, 2003.

SAEKI, K.; YUO, A.; OKUMA, E.; YAZAKI, Y.; SUSIN, S. A.; KROEMER, G.; TAKAKU, F. Bcl-2 down-regulation causes autophagy in a caspase-independent manner in human leukemic HL60 cells. Cell Death. Differ., v. 7, n. 12, p. 1263-9, 2000.

SAITO, A.; NARASIMHAN, P.; HAYASHI, T.; OKUNO, S.; FERRAND-DRAKE, M.; CHAN, P. H. Neuroprotective role of a proline-rich Akt substrate in apoptotic neuronal cell death after stroke: relationships with nerve growth factor. $J$. Neurosci., v. 24, n. 7, p. 1584-93, 2004.

SALDEEN, J. Cytokines induce both necrosis and apoptosis via a common Bcl-2-inhibitable pathway in rat insulin-producing cells. Endocrinology, v. 141, n. 6 , p. 2003-10, 2000.

SALVESEN, G. S.; DUCKETT, C. S. IAP proteins: blocking the road to death's door. Nat. Rev. Mol. Cell Biol., v. 3, n. 6, p. 401-10, 2002.

SAMEJIMA, H.; TORII, C.; KOSAKI, R.; KUROSAWA, K.; YOSHIHASHI, H.; MUROYA, K.; OKAMOTO, N.; WATANABE, Y.; KOSHO, T.; KUBOTA, M.; MATSUDA, O.; GOTO, M.; IZUMI, K.; TAKAHASHI, T.; KOSAKI, K. Screening for Alagille syndrome mutations in the JAG1 and $\mathrm{NOTCH} 2$ genes using 
denaturing high-performance liquid chromatography. Genet. Test., v. 11, n. 3, p. 216-27, 2007.

SCAFFIDI, P.; MISTELI, T.; BIANCHI, M. E. Release of chromatin protein HMGB1 by necrotic cells triggers inflammation. Nature, v. 418, n. 6894, p. 191-5, 2002.

SCHMELZLE, T.; HALL, M. N. TOR, a central controller of cell growth. Cell, v. 103, n. 2, p. 253-62, 2000.

SCHWEICHEL, J. U.; MERKER, H. J. The morphology of various types of cell death in prenatal tissues. Teratology, v. 7, n. 3, p. 253-66, 1973.

SENFTLEBEN, U.; KARIN, M. The IKK/NF-kappa B pathway. Crit. Care. Med., v. 30, n. 1 Suppl, p. S18-26, 2002.

SENFTLEBEN, U.; LI, Z. W.; BAUD, V.; KARIN, M. IKKbeta is essential for protecting $\mathrm{T}$ cells from TNFalpha-induced apoptosis. Immunity, v. 14, n. 3, p. 217-30, 2001.

SHEIKH, M. S.; HUANG, Y. Death receptor activation complexes: it takes two to activate TNF receptor 1. Cell Cycle, v. 2, n. 6, p. 550-2, 2003.

SHI, Y. Caspase activation: revisiting the induced proximity model. Cell, v. 117, n. 7, p. 855-8, 2004.

SHIBATA, M.; HATTORI, H.; SASAKI, T.; GOTOH, J.; HAMADA, J.; FUKUUCHI, Y. Subcellular localization of a promoter and an inhibitor of apoptosis (Smac/ DIABLO and XIAP) during brain ischemia/reperfusion. Neuroreport., v. 13, n. 15 , p. 1985-8, 2002.

SHIRANE, M.; NAKAYAMA, K. I. Inherent calcineurin inhibitor FKBP38 targets Bcl-2 to mitochondria and inhibits apoptosis. Nat. Cell Biol., v. 5, n. 1, p. 28-37, 2003. 
HIRANE, M.; NAKAYAMA, K. I. Immunophilin FKBP38, an inherent inhibitor of calcineurin, targets Bcl-2 to mitochondria and inhibits apoptosis]. Nippon Rinsho, v. 62, n. 2, p. 405-12, 2004.

SIEGELIN, M. D.; KOSSATZ, L. S.; WINCKLER, J.; RAMI, A. Regulation of $\mathrm{XIAP}$ and Smac/DIABLO in the rat hippocampus following transient forebrain ischemia. Neurochem. Int., v. 46, n. 1, p. 41-51, 2005.

SIMON, M. N.; AZEVEDO-MARTINS, A. K.; AMANSO, A. M.; CARVALHO, C. R.; CURI, R. Persistent activation of Akt or ERK prevents the toxicity induced by saturated and polyunsaturated fatty acids in RINm5F beta-cells. Toxicol. In Vitro., v. 22, n. 4, p. 1018-24, 2008.

SKULACHEV, V. P. Fatty acid circuit as a physiological mechanism of uncoupling of oxidative phosphorylation. FEBS Lett., v. 294, n. 3, p. 158-62, 1991.

SOUCEK, L.; WHITFIELD, J.; MARTINS, C. P.; FINCH, A. J.; MURPHY, D. J.; SODIR, N. M.; KARNEZIS, A. N.; SWIGART, L. B.; NASI, S.; EVAN, G. I. Modelling Myc inhibition as a cancer therapy. Nature, v. 455, n. 7213 , p. 67983, 2008.

SOUCIE, E. L.; ANNIS, M. G.; SEDIVY, J.; FILMUS, J.; LEBER, B.; ANDREWS, D. W.; PENN, L. Z. Myc potentiates apoptosis by stimulating Bax activity at the mitochondria. Mol. Cell Biol., v. 21, n. 14, p. 4725-36, 2001.

SRIVASTAVA, S.; CHAN, C. Application of metabolic flux analysis to identify the mechanisms of free fatty acid toxicity to human hepatoma cell line. Biotechnol. Bioeng., v. 99, n. 2, p. 399-410, 2008.

STENTZ, F. B.; KITABCHI, A. E. Palmitic acid-induced activation of human Tlymphocytes and aortic endothelial cells with production of insulin receptors, reactive oxygen species, cytokines, and lipid peroxidation. Biochem. Biophys. Res. Commun., v. 346, n. 3, p. 721-6, 2006.

STOKA, V.; TURK, B.; SCHENDEL, S. L.; KIM, T. H.; CIRMAN, T.; SNIPAS, S. J.; ELLERBY, L. M.; BREDESEN, D.; FREEZE, H.; ABRAHAMSON, M.; 
BROMME, D.; KRAJEWSKI, S.; REED, J. C.; YIN, X. M.; TURK, V.; SALVESEN, G. S. Lysosomal protease pathways to apoptosis. Cleavage of bid, not pro-caspases, is the most likely route. J. Biol. Chem., v. 276, n. 5, p. 3149-57, 2001.

STRAUSS, A. W.; ALBERTS, A. W.; HENNESSY, S.; VAGELOS, P. R. Regulation of synthesis of hepatic fatty acid synthetase: polysomal translation in a cell-free system. Proc. Natl. Acad. Sci. U. S .A., v. 72, n. 11, p. 4366-70, 1975.

SUMITOMO, M.; OHBA, M.; ASAKUMA, J.; ASANO, T.; KUROKI, T.; HAYAKAWA, M. Protein kinase Cdelta amplifies ceramide formation via mitochondrial signaling in prostate cancer cells. J. Clin. Invest., v. 109, n. 6, p. 827-36, 2002.

SUN, C.; CAI, M.; GUNASEKERA, A. H.; MEADOWS, R. P.; WANG, H.; CHEN, J.; ZHANG, H.; WU, W.; XU, N.; NG, S. C.; FESIK, S. W. NMR structure and mutagenesis of the inhibitor-of-apoptosis protein XIAP. Nature, v. 401, n. 6755, p. 818-22, 1999.

SUSIN, S. A.; LORENZO, H. K.; ZAMZAMI, N.; MARZO, I.; SNOW, B. E.; BROTHERS, G. M.; MANGION, J.; JACOTOT, E.; COSTANTINI, P.; LOEFFLER, M.; LAROCHETTE, N.; GOODLETT, D. R.; AEBERSOLD, R.; SIDEROVSKI, D. P.; PENNINGER, J. M.; KROEMER, G. Molecular characterization of mitochondrial apoptosis-inducing factor. Nature, v. 397, n. 6718, p. 441-6, 1999.

SUTCLIFFE, J. E.; BREHM, A. Of flies and men; p53, a tumour suppressor. FEBS Lett., v. 567, n. 1, p. 86-91, 2004.

SUZUKI, S.; SUZUKI, N.; MIRTSOS, C.; HORACEK, T.; LYE, E.; NOH, S. K.; HO, A.; BOUCHARD, D.; MAK, T. W.; YEH, W. C. Nur77 as a survival factor in tumor necrosis factor signaling. Proc. Natl. Acad. Sci. U. S. A., v. 100, n. 14, p. 8276-80, 2003.

SWEENEY, G.; GARG, R. R.; CEDDIA, R. B.; LI, D.; ISHIKI, M.; SOMWAR, R.; FOSTER, L. J.; NEILSEN, P. O.; PRESTWICH, G. D.; RUDICH, A.; KLIP, A. Intracellular delivery of phosphatidylinositol $(3,4,5)$-trisphosphate causes incorporation of glucose transporter 4 into the plasma membrane of muscle and fat cells without increasing glucose uptake. J. Biol. Chem., v. 279, n. 31, p. 32233-42, 2004. 
SZABO, C. Mechanisms of cell necrosis. Crit. Care. Med., v. 33, n. 12 Suppl, p. S530-4, 2005.

TAN, Y.; DEMETER, M. R.; RUAN, H.; COMB, M. J. BAD Ser-155 phosphorylation regulates $\mathrm{BAD} / \mathrm{Bcl}-\mathrm{XL}$ interaction and cell survival. J. Biol. Chem., v. 275, n. 33, p. 25865-9, 2000.

TASHIRO, K.; MAKITA, Y.; SHIKE, T.; SHIRATO, I.; SATO, T.; CYNSHI, O.; TOMINO, Y. Detection of cell death of cultured mouse mesangial cells induced by oxidized low-density lipoprotein. Nephron., v. 82, n. 1, p. 51-8, 1999.

THOMAS, R. K.; KALLENBORN, A.; WICKENHAUSER, C.; SCHULTZE, J. L.; DRAUBE, A.; VOCKERODT, M.; RE, D.; DIEHL, V.; WOLF, J. Constitutive expression of c-FLIP in Hodgkin and Reed-Sternberg cells. Am. J. Pathol., v. 160, n. 4, p. 1521-8, 2002.

THORNBERRY, N. A.; LAZEBNIK, Y. Caspases: enemies within. Science, v. 281, n. 5381, p. 1312-6, 1998.

TIBBETTS, M. D.; ZHENG, L.; LENARDO, M. J. The death effector domain protein family: regulators of cellular homeostasis. Nat. Immunol., v. 4, n. 5, p. 404-9, 2003.

TOLKOVSKY, A. M.; XUE, L.; FLETCHER, G. C.; BORUTAITE, V. Mitochondrial disappearance from cells: a clue to the role of autophagy in programmed cell death and disease? Biochimie, v. 84, n. 2-3, p. 233-40, 2002.

TOLLEFSBOL, T. O.; COHEN, H. J. Culture kinetics of glycolytic enzyme induction, glucose utilization, and thymidine incorporation of extended-exposure phytohemagglutinin-stimulated human lymphocytes. J. Cell. Physiol., v. 122, n. 1, p. 98-104, 1985.

TRONSTAD, K. J.; GJERTSEN, B. T.; KRAKSTAD, C.; BERGE, K.; BRUSTUGUN, O. T.; DOSKELAND, S. O.; BERGE, R. K. Mitochondrialtargeted fatty acid analog induces apoptosis with selective loss of mitochondrial glutathione in promyelocytic leukemia cells. Chem. Biol., v. 10, n. 7, p. 609-18, 2003. 
UNGER, R. H.; ORCI, L. Diseases of liporegulation: new perspective on obesity and related disorders. FASEB J., v. 15, n. 2, p. 312-21, 2001.

URANO, F.; WANG, X.; BERTOLOTTI, A.; ZHANG, Y.; CHUNG, P.; HARDING, H. P.; RON, D. Coupling of stress in the ER to activation of JNK protein kinases by transmembrane protein kinase IRE1. Science, v. 287, n. 5453, p. 664-6, 2000.

VARMA, R.; CHAI, Y.; TRONCOSO, J.; GU, J.; XING, H.; STOJILKOVIC, S. S.; MATTSON, M. P.; HAUGHEY, N. J. Amyloid-beta induces a caspase-mediated cleavage of P2X4 to promote purinotoxicity. Neuromolecular Med., v. 11, n. 2, p. 63-75, 2009.

VERCAMMEN, D.; BROUCKAERT, G.; DENECKER, G.; VAN DE CRAEN, M.; DECLERCQ, W.; FIERS, W.; VANDENABEELE, P. Dual signaling of the Fas receptor: initiation of both apoptotic and necrotic cell death pathways. J. Exp. Med, v. 188, n. 5, p. 919-30, 1998.

VIRAG, L.; SALZMAN, A. L.; SZABO, C. Poly(ADP-ribose) synthetase activation mediates mitochondrial injury during oxidant-induced cell death. $\mathbf{J}$ Immunol., v. 161, n. 7, p. 3753-9, 1998.

WAJANT, H.; SCHEURICH, P. Analogies between Drosophila and mammalian TRAF pathways. Prog. Mol. Subcell. Biol., v. 34, p. 47-72, 2004.

WALKER, N. I.; HARMON, B. V.; GOBE, G. C.; KERR, J. F. Patterns of cell death. Methods Achiev. Exp. Pathol., v. 13, p. 18-54, 1988.

WANG, H.; BLOOM, O.; ZHANG, M.; VISHNUBHAKAT, J. M.; OMBRELLINO, M.; CHE, J.; FRAZIER, A.; YANG, H.; IVANOVA, S.; BOROVIKOVA, L.; MANOGUE, K. R.; FAIST, E.; ABRAHAM, E.; ANDERSSON, J.; ANDERSSON, U.; MOLINA, P. E.; ABUMRAD, N. N.; SAMA, A.; TRACEY, K. J. HMG-1 as a late mediator of endotoxin lethality in mice. Science, v. 285, n. 5425, p. 248-51, 1999.

WANG, H.; YANG, H.; TRACEY, K. J. Extracellular role of HMGB1 in inflammation and sepsis. J. Intern. Med., v. 255, n. 3, p. 320-31, 2004. 
WANG, H. G.; PATHAN, N.; ETHELL, I. M.; KRAJEWSKI, S.; YAMAGUCHI, Y.; SHIBASAKI, F.; MCKEON, F.; BOBO, T.; FRANKE, T. F.; REED, J. C. Ca2+induced apoptosis through calcineurin dephosphorylation of BAD. Science, v. 284, n. 5412, p. 339-43, 1999.

WANG, R.; ZHANG, L.; YIN, D.; MUFSON, R. A.; SHI, Y. Protein kinase C regulates Fas (CD95/APO-1) expression. J. Immunol., v. 161, n. 5, p. 2201-7, 1998.

WESTON, C. R.; LAMBRIGHT, D. G.; DAVIS, R. J. Signal transduction. MAP kinase signaling specificity. Science, v. 296, n. 5577, p. 2345-7, 2002.

WILSON, C. A.; BROWNING, J. L. Death of HT29 adenocarcinoma cells induced by TNF family receptor activation is caspase-independent and displays features of both apoptosis and necrosis. Cell Death Differ., v. 9, n. 12, p. 1321-33, 2002.

WINOTO, A.; LITTMAN, D. R. Nuclear hormone receptors in T lymphocytes. Cell, v. 109 Suppl, p. S57-66, 2002.

WU, G.; FANG, Y. Z.; YANG, S.; LUPTON, J. R.; TURNER, N. D. Glutathione metabolism and its implications for health. J. Nutr., v. 134, n. 3, p. 489-92, 2004.

WU, H.; ICHIKAWA, S.; TANI, C.; ZHU, B.; TADA, M.; SHIMOISHI, Y.; MURATA, Y.; NAKAMURA, Y. Docosahexaenoic acid induces ERK1/2 activation and neuritogenesis via intracellular reactive oxygen species production in human neuroblastoma SH-SY5Y cells. Biochim. Biophys. Acta., v. 1791, n. 1, p. 8-16, 2009.

WYLLIE, A. H.; KERR, J. F.; CURRIE, A. R. Cell death: the significance of apoptosis. Int. Rev. Cytol., v. 68, p. 251-306, 1980.

XIAO, G. G.; WANG, M.; LI, N.; LOO, J. A.; NEL, A. E. Use of proteomics to demonstrate a hierarchical oxidative stress response to diesel exhaust particle 
chemicals in a macrophage cell line. J. Biol. Chem., v. 278, n. 50, p. 50781-90, 2003.

XU, W.; LIU, L.; CHARLES, I. G.; MONCADA, S. Nitric oxide induces coupling of mitochondrial signalling with the endoplasmic reticulum stress response. Nat. Cell .Biol,. v. 6, n. 11, p. 1129-34, 2004.

YAFFE, M. B. Master of all things phosphorylated. Biochem. J., v. 379, n. Pt 2, p. e1-2, 2004.

YAN, N.; SHI, Y. Histone H1.2 as a trigger for apoptosis. Nat. Struct. Biol., v. 10, n. 12, p. 983-5, 2003.

YANEY, G. C.; CORKEY, B. E. Fatty acid metabolism and insulin secretion in pancreatic beta cells. Diabetologia, v. 46, n. 10, p. 1297-312, 2003.

YANG, H.; WANG, H.; CZURA, C. J.; TRACEY, K. J. The cytokine activity of HMGB1. J. Leukoc. Biol., v. 78, n. 1, p. 1-8, 2005.

YAQOOB, P. Fatty acids and the immune system: from basic science to clinical applications. Proc. Nutr. Soc., v. 63, n. 1, p. 89-104, 2004.

YAQOOB, P.; CALDER, P. C. Glutamine requirement of proliferating T lymphocytes. Biochem .Soc. Trans., v. 24, n. 1, p. 78S, 1996.

YASMIN, W.; STRYNADKA, K. D.; SCHULZ, R. Generation of peroxynitrite contributes to ischemia-reperfusion injury in isolated rat hearts. Cardiovasc .Res., v. 33, n. 2, p. 422-32, 1997.

YIN, X. M.; WANG, K.; GROSS, A.; ZHAO, Y.; ZINKEL, S.; KLOCKE, B.; ROTH, K. A.; KORSMEYER, S. J. Bid-deficient mice are resistant to Fas-induced hepatocellular apoptosis. Nature, v. 400, n. 6747, p. 886-91, 1999.

YOOK, Y. H.; KANG, K. H.; MAENG, O.; KIM, T. R.; LEE, J. O.; KANG, K. I.; KIM, Y. S.; PAIK, S. G.; LEE, H. Nitric oxide induces BNIP3 expression that causes cell death in macrophages. Biochem. Biophys. Res. Commun., v. 321, n. 2, p. 298-305, 2004. 
YOON, S.; SEGER, R. The extracellular signal-regulated kinase: multiple substrates regulate diverse cellular functions. Growth Factors, v. 24, n. 1, p. 21-44, 2006.

YOSHIDA, K. PKCdelta signaling: mechanisms of DNA damage response and apoptosis. Cell Signal, v. 19, n. 5, p. 892-901, 2007.

YOU, Z.; MADRID, L. V.; SAIMS, D.; SEDIVY, J.; WANG, C. Y. c-Myc sensitizes cells to tumor necrosis factor-mediated apoptosis by inhibiting nuclear factor kappa B transactivation. J. Biol. Chem., v. 277, n. 39, p. 36671-7, 2002.

YU, C.; CHEN, Y.; CLINE, G. W.; ZHANG, D.; ZONG, H.; WANG, Y.; BERGERON, R.; KIM, J. K.; CUSHMAN, S. W.; COONEY, G. J.; ATCHESON, B.; WHITE, M. F.; KRAEGEN, E. W.; SHULMAN, G. I. Mechanism by which fatty acids inhibit insulin activation of insulin receptor substrate-1 (IRS-1)associated phosphatidylinositol 3-kinase activity in muscle. J. Biol. Chem., v. 277, n. 52, p. 50230-6, 2002.

YUAN, J.; LIPINSKI, M.; DEGTEREV, A. Diversity in the mechanisms of neuronal cell death. Neuron., v. 40, n. 2, p. 401-13, 2003.

ZAMORA, R.; VODOVOTZ, Y.; BETTEN, B.; WONG, C.; ZUCKERBRAUN, B.; GIBSON, K. F.; FORD, H. R. Intestinal and hepatic expression of BNIP3 in necrotizing enterocolitis: regulation by nitric oxide and peroxynitrite. Am. J. Physiol. Gastrointest. Liver Physiol., v. 289, n. 5, p. G822-30, 2005.

ZECHNER, R.; STRAUSS, J. G.; HAEMMERLE, G.; LASS, A.; ZIMMERMANN, R. Lipolysis: pathway under construction. Curr. Opin. Lipidol., v. 16, n. 3, p. 333-40, 2005.

ZERMATI, Y.; GARRIDO, C.; AMSELLEM, S.; FISHELSON, S.; BOUSCARY, D.; VALENSI, F.; VARET, B.; SOLARY, E.; HERMINE, O. Caspase activation is required for terminal erythroid differentiation. J. Exp. Med. v. 193, n. 2, p. 247-54, 2001. 
ZHA, J.; WEILER, S.; OH, K. J.; WEI, M. C.; KORSMEYER, S. J. Posttranslational $\mathrm{N}$-myristoylation of BID as a molecular switch for targeting mitochondria and apoptosis. Science, v. 290, n. 5497, p. 1761-5, 2000.

ZHANG, D.; SHEN, J.; WANG, C.; ZHANG, X.; CHEN, J. GSH-dependent iNOS and HO-1 mediated apoptosis of human Jurkat cells induced by nickel(II). Environ. Toxicol., v. 24, n. 4, p. 404-14, 2009.

ZHANG, X. K. Vitamin A and apoptosis in prostate cancer. Endocr. Relat. Cancer., v. 9, n. 2, p. 87-102, 2002.

ZHAO, Y.; COLOFF, J. L.; FERGUSON, E. C.; JACOBS, S. R.; CUI, K.; RATHMELL, J. C. Glucose metabolism attenuates p53 and Puma-dependent cell death upon growth factor deprivation. J. Biol. Chem., v. 283, n. 52, p. 36344-53, 2008.

ZHOU, L. L.; ZHOU, L. Y.; LUO, K. Q.; CHANG, D. C. Smac/DIABLO and cytochrome $c$ are released from mitochondria through a similar mechanism during UV-induced apoptosis. Apoptosis, v. 10, n. 2, p. 289-99, 2005.

ZHOU, Y. P.; GRILL, V. E. Long-term exposure of rat pancreatic islets to fatty acids inhibits glucose-induced insulin secretion and biosynthesis through a glucose fatty acid cycle. J. Clin. Invest., v. 93, n. 2, p. 870-6, 1994.

ZOU, H.; LI, Y.; LIU, X.; WANG, X. An APAF-1.cytochrome c multimeric complex is a functional apoptosome that activates procaspase-9. J. Biol. Chem., v. 274, n. 17, p. 11549-56, 1999. 
ANEXO 


\title{
ACTIVATION OF SURVIVAL AND APOPTOTIC SIGNALING PATHWAYS IN LYMPHOCYTES EXPOSED TO PALMITIC ACID\#
}

\author{
Hilton Kenji Takahashi*, Tavane David Cambiaghi, Augusto Ducati \\ Luchessi*, Marco Aurelio Ramirez Vinolo *, Sandro Massao Hirabara**, \\ Philip Newsholme*** and Rui Curi* \\ * Department of Physiology and Biophysics, Institute of Biomedical \\ Sciences, University of São Paulo, Brazil \\ ${ }^{* *}$ Cruzeiro do Sul University, Brazil \\ ${ }^{* * *}$ UCD School of Biomolecular and Biomedical Science, UCD Conway \\ Institute, University College Dublin, Ireland
}

To whom correspondence should be addressed: Av. Prof. Lineu Prestes, 1524, 05508-900, Cidade Universitária, São Paulo, SP, Brazil. E-mail: hilton@icb.usp.br, Telephone: 5511 3091-7245, Fax: 55113091 \# This work was supported by FAPESP, CNPq and CAPES

\section{ABSTRACT}

The toxicity of palmitic acid (PA, an abundant plasma and cell associated saturated fatty acid) towards human T-lymphocyte cell line (Jurkat) has been previously investigated. In the current study, Jurkat cells were treated with sublethal concentrations of PA $(50,100$ and $150 \mu \mathrm{M})$ and the activity of various signaling proteins was investigated. We initially determined that PA induced apoptosis and mitochondrial dysfunction in a dose dependent manner as evaluated by DNA fragmentation assay and depolarization of the mitochondrial membrane respectively. PA treatment led to release of cytochrome c from the 
inner mitochondrial membrane to the cytosol, activated members of the MAPK protein family JNK, p38, ERK, and activated caspases-9 and 3. Exposure of cells to PA for $12 \mathrm{~h}$ increased insulin receptor and GLUT-4 levels in the plasma membrane. The same effect was observed in human lymphocytes obtained from healthy donors. Insulin treatment $(10 \mathrm{mU} / \mathrm{mL}$ for 30 minutes) promoted a significant increase in the phosphorylation state of the insulin receptor $\beta$-subunit and Akt. A correlation was found between cell DNA fragmentation and expression levels of both the insulin receptor and GLUT-4. Glucose uptake by cells increased when incubated in the presence of PA but in the absence of insulin was observed. Glucose oxidation was diminished by PA treatment and there was an accumulation of neutral lipids (triglyceride) and other lipid classes (phospholipids and cholesterol ester). Our results suggest that parameters of insulin signaling and non-oxidative glucose metabolism are stimulated as part of a coordinated response to cell survival in lymphocytes exposed to PA.

Keywords: Apoptosis, Lymphocytes, Jurkat cells, Palmitic acid, Insulin Receptor, GLUT-4.

Abbreviations: IR, Insulin receptor; GLUT, Glucose Transporter; PA, Palmitic Acid;

\section{INTRODUCTION}

Careful regulation of cell survival and death is critical for the functioning of 
the mammalian immune system. Apoptosis plays an important role to regulate the length of time and extension of an immune response $(1,2)$. Apoptosis ensures a functional repertoire of mature $B$ and $T$ cells, and maintains tolerance toward self $(3,4)$. Particularly, lymphocyte apoptosis is important for removal of cells that failed to express an antigen receptor. Lymphocytes also undergo apoptosis when an infection is successfully cleared (5).

The signaling events that lead to cell death by apoptosis can be divided into two distinct pathways that involve mitochondria (intrinsic pathway) or death receptors (extrinsic pathway) (6). In the extrinsic pathway, death 'ligands' unleash the apoptotic pathway through death receptors that belong to the TNF super family receptors. In lymphocytes, the most important members of this family involved in the intracellular signaling are: TNF receptors type 1 and 2, known as CD120a and CD120b, and Fas receptor, also known as CD95 (7). The attachment of ligands to these receptors initiates the recruitment of effectors that stimulates intracellular signals resulting in cell death or, if the stimulus is not sufficient, survival. Usually these effector molecules are enzymes such as protein kinases, protein phosphatases and proteases (8). Apoptosis can be induced via the intrinsic pathway by deprivation of growth and differentiation factors, defects in receptor signaling, and exposure to drugs or agents that can damage DNA such as UV radiation. These stimuli promote the translocation of pro-apoptotic proteins, such as Bax, to mitochondria altering the integrity of this organelle membrane. Mitochondria then release various apoptotic effectors such as cytochrome c, AIF and Smac/DIABLO that can activate the cell death machinery (9). This machinery is driven by a proteolytic 
system involving a family of aspartate-specific cysteine proteases called caspases. These enzymes participate in a cascade that is triggered in response to pro-apoptotic signals and culminates in cleavage of structural and regulatory proteins, resulting in disassembly of the cell (10). In the intrinsic pathway, cytochrome c associates with apoptosis protease-activating factor-1 (APAF-1) and caspase- 9 to form the apoptosome that triggers the activation of downstream cascade of effector proteases (11, 12). Activated effector caspases then mediate the proteolysis of a range of substrates including other caspases such as caspase-3 and cytoskeletal proteins as actin and laminin (4).

Fatty acids are known to play diverse roles for immune cell function acting as a source of carbon for oxidation to $\mathrm{CO}_{2}$, as structural components of cell membrane phospholipids, as signaling molecules and as precursors for the synthesis of eicosanoids and others mediators (12). However, there is increasing evidence that free fatty acids can cause cell death through activation of apoptosis. Several mechanisms have been described to account for PA induced apoptosis such as: endoplasmatic reticulum stress (13), de novo ceramide synthesis (14), and via p38 MAPK pathway activation (15).

Lymphocytes use both glucose and glutamine as metabolic fuels at high rates even when they are immunological quiescent (16).T-Lymphocytes in their basal state express low levels of IR and GLUT-4, and cellular glucose uptake is mediated by GLUT-1 $(17,18)$. During activation of T-lymphocytes, insulin receptors and other GLUT isoforms (1,3 and 4) are translocated to the plasma membrane (18-21). In the present study, death signaling pathways (release of cytochrome c, activation of caspases 3 and 9, and expression/activation of MAPK proteins p38, JNK and ERK) were investigated in PA-treated Jurkat cells. 
Previous studies have shown that insulin and increased glucose metabolism act to protect against cell death (22-25).

Thus we investigated activation of some components of the insulin signaling pathway and glucose metabolism were investigated with respect to cell survival or apoptosis induced by PA.

\section{MATERIALS AND METHODS}

Chemicals - Cell culture medium, antibiotics and fetal calf serum (FCS) were obtained from Gibco Life Technologies (Grand Island, NY, USA). Insulin receptor, phospho-Insulin receptor and GLUT-4 antibodies were obtained from Santa Cruz (Santa Cruz, CA, USA). Akt and phospho-Akt (ser-473), p38, phospho-p38, SAPK/JNK, phospho-SAPK/JNK, p44MAPK, phospho-p44 MAPK antibodies were obtained from Cell Signaling (Danvers, MA, USA). All other reagents were obtained from Sigma Chemical Co. (St. Louis, MO, USA).

Cell Line - Jurkat cells were obtained from the Dunn School of Pathology (Oxford University, UK). The cells were maintained in log-phase growth at $37^{\circ} \mathrm{C}$ and in a $5 \% \quad \mathrm{CO}_{2}$ humidified atmosphere. Cells were grown in RPMI-1640 medium supplemented with 10\% FCS, $20 \mathrm{mM}$ HEPES, $10 \mathrm{U} / \mathrm{ml}$ ampicilin and $10 \mu \mathrm{g} / \mathrm{ml}$ streptomycin. Cell population was kept between $1 \times 10^{5}$ and $1 \times 10^{6}$ cells per $\mathrm{ml}$.

Cell treatment - The cells were diluted to $2 \times 10^{5}$ per ml. After 24 hours culture, when the number of cells reached $4 \times 10^{5}$ cells per ml, PA $(50,100,150$ $\mu \mathrm{M})$ was added to the medium. The ethanol solution used to dilute palmitic acid was always lower than $0.05 \%$ of the culture medium. This concentration of 
ethanol has shown not to be toxic for the cells (data not shown). The experiments were carried out at $37^{\circ} \mathrm{C}$ in a $5 \% \mathrm{CO}_{2}$ humidified atmosphere.

Human lymphocyte preparation - Lymphocytes were isolated from blood $(10 \mathrm{ml})$ of healthy volunteers and diluted with an equal volume of PBS (phosphate buffer saline), at $\mathrm{pH} \mathrm{7.4 \text {,containing } 1 0 0 \mathrm { mM } \mathrm { CaCl } _ { 2 } , 5 0 \mathrm { mM } \mathrm { MgCl }}$ and carefully layered on $10 \mathrm{ml}$ Lymphoprep@ $(\mathrm{d}=1.077)$ (Sigma Chemical Co, St Louis, MO, USA). The tubes were centrifuged at $1,200 \mathrm{rpm}$ at $4^{\circ} \mathrm{C}$ for $30 \mathrm{~min}$ and the supernatant, rich in mononuclear cells, was separated and submitted to incubation in cell culture flask with RPMI-1640 medium for 1 hour at $37^{\circ} \mathrm{C}$ and in a $5 \% \mathrm{CO}_{2}$ humidified atmosphere. This procedure allows monocyte to adhere to the flask surface. The medium was centrifuged at $1,200 \mathrm{rpm}$ and $4^{\circ} \mathrm{C}$ for 10 min and lymphocytes were ressuspended in PBS. The number of viable (>95\%) lymphocytes was determined by trypan blue exclusion. All experimental protocol involving humans were approved by the ethical committee of the Institute of Biomedical Sciences, University of São Paulo.

DNA fragmentation assay - Cells were centrifuged at high speed $(12,000$ rpm) for $20 \mathrm{~s}$. The pellet was washed and ressuspended in $0.2 \mathrm{ml}$ of lysis buffer ( $0.1 \%$ sodium citrate and $0.1 \%$ Triton $X-100)$ containing $50 \mu \mathrm{g} / \mathrm{mL}$ of PI. Lysed cells were then incubated in the dark, at $4{ }^{\circ} \mathrm{C}$ for $24 \mathrm{~h}$, and used for DNA fragmentation analysis. PI intercalates between bases in double-stranded nucleic acids of exposed nuclei. After incubation, samples were evaluated in a 
FACScalibur flow cytometric equipment (Becton Dickinson, CA, USA) by using the Cell Quest software. Ten thousand events were evaluated per experiment. PI fluorescence was measured in the FL2 channel (620 nm).DNA fragmentation is observed by the occurrence of low fluorescent particles. This indicates DNA cleavage since high condensed and small size fragments cannot be intensively bound by PI.

Mitochondrial membrane depolarization assay - $1 \times 10^{6}$ cells were centrifuged at $1000 \times \mathrm{g}$ for $15 \mathrm{~min}$ at $4^{\circ} \mathrm{C}$ and the pellet obtained was ressuspended in $1 \mathrm{ml}$ PBS. Rhodamine 123 is a cell-permeable, cationic, fluorescent dye that is readily sequestered by active mitochondria without inducing cytotoxic effects. Uptake and equilibration of rhodamine 123 is rapid. Therefore, rhodamine 123 allows for quick and easy detection of changes in mitochondrial membrane potential. Rhodamine $123(5 \mu \mathrm{M})$ was added and the cells were then incubated for $15 \mathrm{~min}$ at $37^{\circ} \mathrm{C}$ in the dark. Afterwards, the cells were washed twice with cold PBS and incubated for 30 min at $30^{\circ} \mathrm{C}$ in the dark. Fluorescence of rhodamine 123 was determined using the FL1 channel (Green fluorescence-530/30 nm).

Assay for Insulin receptor and GLUT-4 proteins - These proteins were analyzed by both flow cytometry and western blotting. Cells were centrifuged at 1,200 rpm for 10 minutes and incubated with IR or GLUT-4 antibodies in PBS at 1:50 ratio. After 1 hour incubation, cells were washed and ressuspended in medium with secondary antibody conjugated with FITC at $1: 100$ ratio. Cells were incubated for 1 hour, washed and ressuspended in PBS. FITC fluorescence intensity was measured in FL1 channel. Results are presented as 
mean of fluorescence intensity.

Subcellular fractionation - For detection of cytochome c redistribution, both the cytosolic and mitochondria fractions were isolated from treated cells by washing in ice-cold PBS. The cells were then lysed using lysis buffer $(250 \mathrm{mM}$ sucrose, $70 \mathrm{mM} \mathrm{KCl}$ and $2 \mathrm{mg} / \mathrm{ml}$ digitonin in PBS) on ice for $5 \mathrm{~min}$, cell suspension was centrifuged at $250 \mathrm{~g}$ for $5 \mathrm{~m}$ at $4^{\circ} \mathrm{C}$. The supernatant was removed and stored at $-70^{\circ} \mathrm{C}$ as the cytosolic fraction. The pellet was ressuspended in immunoprecipitation buffer (100 mM Tris-HCl, $\mathrm{pH}$ 7.0; $10 \mathrm{mM}$ EDTA; $100 \mathrm{mM} \mathrm{NaF} ; 10 \mathrm{mM}$ sodium pyrophosphate; $10 \mathrm{mM}$ sodium orthovanadate and $0.1 \mathrm{mM}$ PMSF) and placed on ice for $10 \mathrm{~min}$. The suspension was centrifuged at $12,000 \mathrm{rpm}$ for $10 \mathrm{~min} \mathrm{t} 4^{\circ} \mathrm{C}$ and the supernatant was stored as mitochondrial fraction at $-70^{\circ} \mathrm{C}$. The fractions were submitted to a western blotting assay.

Western blotting assay- After the incubation period, cells were centrifuged at 1,200 rpm for 10 minutes and homogenized in extraction buffer (100 mM Tris- $\mathrm{HCl}, \mathrm{pH} 7.0 ; 10 \mathrm{mM}$ EDTA; $100 \mathrm{mM} \mathrm{NaF} ; 10 \mathrm{mM}$ sodium pyrophosphate; $10 \mathrm{mM}$ sodium orthovanadate; at $100^{\circ} \mathrm{C}$ ). The samples were sonicated and SDS (10\%) was added followed by 30 minutes of incubation on ice. After that, samples were centrifuged at $12,000 \mathrm{rpm}$, for $40 \mathrm{~min}$, at $4^{\circ} \mathrm{C}$. Aliquots of supernatants were used for measurement of total protein content as described by Bradford (26). Equal amounts of proteins of each sample were separated using SDS-polyacrylamide gel (27). Western blotting was carried out following the method described by Towbin et al.(28). Proteins of the gel were 
transferred to a nitrocellulose membrane at $120 \mathrm{~V}$ for $1 \mathrm{~h}$. Non-specific bounds were blocked by incubating the membranes with $10 \%$ defatted milk in TBS-T solution (10 mM Tris- $\mathrm{HCl}$, pH 7.0; 150 mM NaCl; 0.05\% Tween 20). Membranes were washed in TBS-T and then incubated with respective antibodies in TBS-T solution containing $5 \%$ albumin, at $4^{\circ}$, overnight. Membranes were washed again and incubated with anti-IgG antibody linked to horseradish peroxidase in TBS-T solution containing 5\% albumin for 1 hour. Following washing again, membranes were incubated with substrate for peroxidase and chemiluminescence enhancer Amersham ECL (GE Healthcare, Buckinghamshire, England) for $1 \mathrm{~min}$ and immediately exposed to X-ray film for 1-20 min. Films were then revealed in the conventional manner. Band intensities were quantified by optical densitometry using the Image-J program (Frederick, MD, USA).

Immunoprecipitation - At the end of the incubation period, cell proteins were extracted as described in the western blotting protocol. Aliquots of extracted protein samples were used for measurement of total protein content as described by Bradford (26). Equal amounts of proteins of each sample were complexed with respective antibody (anti-IR, anti-phospho-IR, and anti-GLUT-4) for an overnight period. The immunocomplexes were then precipitated with Protein A Sepharose 6MB (GE Healthcare, Buckinghamshire, England) and submitted to a $12 \%$ SDS-PAGE electrophoresis. The proteins of the gel were electrically transferred to a nitrocellulose membrane and submitted to the western blot procedure described above. 
Glucose uptake measurement - After treatment with PA, cells (1x106) were transferred to tubes and incubated at $37^{\circ} \mathrm{C}$ either in the absence or in the presence of insulin $(10 \mathrm{mU} / \mathrm{ml})$ for 25 minutes. Subsequently, PBS containing $0.5 \mathrm{mM}$ 2-deoxy-D-glucose and $0.5 \mu \mathrm{Ci}$ 2-[1, 2 -3H] deoxy-D-glucose was added to cells for 5 minutes. Incubations were then stopped by addition of cytochalasin B (50 $\mu \mathrm{M}$ final concentration). The cells were then separated from radioactive incubation medium by centrifugation for $30 \mathrm{~s}(5,000 \mathrm{rpm})$. An aliquot of cells were used to determine the protein concentration in each sample by using the Bradford method (26). Cells and incubation media were then transferred to scintillation vials and radioactivity was counted in a Beckman-LS 5000 TD scintillating counter (Beckman Instruments, Fullerton, CA, USA).

Glucose oxidation assay - Glucose oxidation was determined by the conversion of $\mathrm{D}-\left[\mathrm{U}-{ }^{14} \mathrm{C}\right]$ glucose into ${ }^{14} \mathrm{CO}_{2}$. Briefly, cells $\left(1 \times 10^{6}\right)$, after treatment with PA, were incubated for $1 \mathrm{~h}$ at $37{ }^{\circ} \mathrm{C}$ in scintillation vials containing $1 \mathrm{ml}$

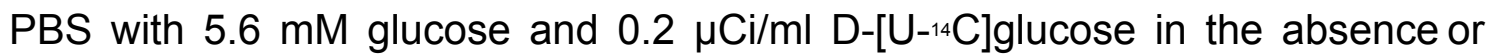
presence of insulin $(10 \mathrm{mU} / \mathrm{ml})$. The scintillation flasks had a centered isolated well containing a loosely folded piece of filter paper moistened with $0.2 \mathrm{ml} 2-$ phenylethylamine/methanol $(1: 1, \mathrm{v} / \mathrm{v})$. After the 1 -h incubation period, the medium was acidified with $0.4 \mathrm{ml} \mathrm{HCl}(5 \mathrm{~N})$ and the flasks were maintained sealed at $37{ }^{\circ} \mathrm{C}$ for an additional 30 min period. At the end of this period, filter papers were carefully removed and transferred to scintillation vials for 
radioactivity measurement.

Incorporation of [ $\left.{ }^{14} \mathrm{C}\right]-$ palmitic acid into lipid fractions - Jurkat cells were treated with PA $(50,100$ and $150 \mu \mathrm{M})$ and with the addition of $0.5 \mu \mathrm{Ci}\left[{ }^{14} \mathrm{C}\right]-$ palmitic acid. After 24 hour incubation, the cells were submitted to lipid extraction using Folch's method (29). Dried samples were ressuspended in 50 $\mu$ l chloroform/methanol $(2: 1 \mathrm{v} / \mathrm{v})$ and chromatographed using a thin layer chromatographic plate with a $250 \mu \mathrm{m}$ stationary phase of silica gel (Sigma Chemical Co, St Louis, MO, USA) and a solvent system consisting of hexane/ diethyl ether/ acetic acid (70:30:1, by volume) All solvents used were of HPLC grade (Merck KGaA, Darmstadt, Germany). The plate was kept in a glass chamber containing iodine to visualize the lipid spots. Lipid spots were gently scraped from silica plates and transferred to scintillation vials for radioactivity measurement.

\section{Determination of fatty acid composition}

Total lipids from Jurkat treated cells were extracted as previously described by Folch et al (29). The lipids were saponified using $2 \mathrm{~mL}$ of an alkaline methanol solution ( $1 \mathrm{~mol}$ per $\mathrm{mL} \mathrm{NaOH}$ in $90 \%$ methanol) at $37^{\circ} \mathrm{C}$ for $2 \mathrm{~h}$ in a shaking water bath. Afterwards, the alkaline solution was acidified to $\mathrm{pH}$ 3 with $\mathrm{HCl}$ solution $(1 \mathrm{~mol} / \mathrm{mL})$. Fatty acids were then extracted three times with $2 \mathrm{~mL}$ hexane. After the extraction procedure and saponification the fatty acids were derivatized with 4-bromomethyl-7 coumarin (30), and the analysis performed in a liquid chromatographer (Shimadzu model LC-10A, Shimadzu, 
Kyoto, Japan). The samples were eluted using a C8 column $(25 \mathrm{~cm} \times 4.6$ i.d., $5 \mu \mathrm{m}$ of particles) with pre-column C8 (2.5 cm $\times 4.6$ i.d., $5 \mu \mathrm{m}$ of particles), $1 \mathrm{~mL}$ per minute of acetonitrile/water $(77: 23 \mathrm{v} / \mathrm{v})$ flow and fluorescence detector (325 nm excitation and 395 emission).

Statistical analysis -The results are presented as mean \pm standard error of mean (S.E.M.) and analyzed by one-way or two-way ANOVA with Tukey or Bonferroni post-hoc tests, respectively. The level of significance was set at $p<$ 0.05. Linear regression analysis was used to verify the correlations between DNA fragmentation and insulin receptor or GLUT-4 abundance. 


\section{RESULTS}

Effect of PA on markers of cell death - Incubation with PA (50, 100 or $150 \mu \mathrm{M})$ raised the proportion of Jurkat cells with fragmented DNA (Figure1). There was an increase in the percentage of cells presenting with a depolarization of the mitochondrial membrane following incubation with PA, in a

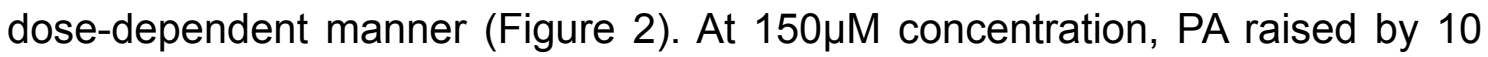
fold the percentage of cells with depolarized mitochondria when compared to control. PA also increased cytochrome $\mathrm{c}$ release from the mitochondria to the cytosol. A significant increase in the active forms of caspases 3 and 9 following PA treatment, was determined by western blotting analysis (Figure 3).

The effect of PA on Jurkat cell death signaling - The main kinases involved in activation of apoptosis, including JNK, p38 MAPK and ERK, were assessed by western blotting. PA induced JNK phosphorylation, whereas the level of JNK total protein was not altered. p38 MAPK phosphorylation was also augmented by PA treatment. PA also significantly increased the level of ERK phosphorylation (Figure 4). 
Analysis of IR and GLUT-4 following PA exposure - PA increased the abundance of IR and GLUT-4 on Jurkat cell plasma membrane after $12 \mathrm{~h}$ treatment as observed by flow cytometry (Figures $5 \mathrm{~A}$ and $5 \mathrm{C}$ ). A strong correlation was observed between DNA fragmentation and expression of IR $\left(\mathrm{r}^{2}=\right.$ 0.91) or GLUT-4 $\left(r^{2}=0.74\right)$ (Figures 5B and 5D). Similar results were obtained with human lymphocytes after 24 hours of treatment with PA (Figure 6). Again, a strong correlation was obtained between DNA fragmentation and expression of IR and GLUT-4; $r^{2}=0.85$ and 0.8 , respectively.

An immunoblot assay of IR and GLUT-4 was carried out to confirm the observations obtained by flow cytometry. (Figure 7).

The effect of PA on the Insulin signaling pathway - Components of the insulin signaling pathway were evaluated. After 24 hour incubation with PA, cells were treated with insulin $(10 \mathrm{mU} / \mathrm{ml})$ for 30 minutes. Insulin was able to promote IR- $\beta$ phosphorylation in these conditions as indicated by western blotting analysis (Figure 7). Insulin also raised the phosphorylation of Akt in serine-473 position (Figure 8).

The effect of PA on Jurkat cell glucose metabolism - As PA increased the expression of IR and GLUT-4 in Jurkat cells then we investigated glucose uptake by these cells. PA increased the uptake of glucose by Jurkat cells but this effect was not further enhanced by the addition of insulin. PA treated cells exhibited diminished $\mathrm{CO}_{2}$ production from [U-14 $\mathrm{C}$ ] glucose as compared to control cells incubated in the absence of PA (Figure 9). 
Effect of PA treatment on intracellular lipid content - After $24 \mathrm{~h}$ treatment, $\left.{ }^{14} \mathrm{C}\right]$-palmitic acid was found to be incorporated into all lipid classes analyzed (triglycerides, cholesterol ester, phospholipids and free fatty acids). Palmitic acid increased in a dose-dependent manner the content of cell associated triglyceride, free fatty acid fraction and phospholipids. Cholesterol ester content was significantly increased only in cells treated with $150 \mu \mathrm{M}$ PA when compared to control cells incubated in the absence of PA (Figure 10).

Analysis of cellular fatty acid composition - The composition of fatty acids from Jurkat cells is described in Table 1. PA treatment significantly increased PA content in Jurkat cells. For incubation concentrations of 50, 100 and $150 \mu \mathrm{M}$ PA there was $1.25,1.95$ and 2.77 fold increase over control, respectively.

\section{DISCUSSION}

PA induced apoptosis of Jurkat cells in a dose-dependent manner as indicated by DNA fragmentation, mitochondrial membrane depolarization, cytochrome c release and activation of caspases 3 and 9 . These findings indicate PA activation of intrinsic apoptotic pathways involving the mitochondria. One or more death signaling pathways involving JNK, p38 and ERK were also activated. Concomitantly, PA treated-Jurkat cells exhibited an increase of IR and GLUT-4 content in their plasma membrane in the absence of insulin. PA treatment increased glucose uptake but diminished its conversion to $\mathrm{CO}_{2}$, and raised the content of the major lipid classes: triglyceride, cholesterol ester, free fatty acid and phospholipids. 
Mitochondria play a central role in the regulation of apoptosis due to the involvement of pro-apoptotic proteins, such as cytochrome c, Smac/DIABLO and AIF, that are confined in its intermembrane space and released in response to apoptotic stimuli such as growth factor deprivation, UV exposure and production of reactive oxygen species $(31,32)$. Mitochondrial injury is mediated by the opening of the permeability transition pore that leads to depolarization of the mitochondrial membrane and the release of inner membrane and matrix contents into the cytosol, including cytochrome c $(33,34)$. PA treatment increased the proportion of Jurkat cells with depolarized mitochondrial membrane in a dose dependent manner. Previously Cury-Boaventura et al showed that oleic acid and linoleic acid can promote death of both human lymphocyte and Jurkat cells $(35,36)$. The latter authors observed an increase in mitochondrial membrane depolarization and associated the mitochondrial changes with ROS production and disruption of redox balance.

Cytochrome c promotes caspase- 9 activation through the complex formation with apoptotic protease activating factor 1 (Apaf-1) (37), which leads to cleavage and activation of caspase-3. Caspase-3 is one of the key executioners of apoptosis, being responsible either partially or totally for the proteolytic cleavage of many key proteins such as the nuclear enzyme poly (ADP-ribose) polymerase (PARP) (38). PA increased the release of cytochrome c from Jurkat cell mitochondria to the cytosol and activated caspases 9 and 3 . PA augmented the phosphorylation state of JNK and p38 MAPK proteins, both members of the MAPK superfamily that are responsive to stress stimuli ranging from osmotic shock and ionizing radiation to cytokine stimulation (39). Other studies, e.g. Ogino et al (40) and Lee et al (41) have demonstrated activation 
of the JNK pathway in Jurkat cells resulting in apoptosis using monochloramine, a neutrophil-derived oxidant, and lactoferrin, a multi-functional iron-binding glycoprotein. Several mechanisms have been postulated for the apoptotic effect of fatty acids: generation of ROS $(42,43)$, nitric oxide synthesis $(44)$ and de novo synthesis of ceramides (45). The relative contribution of these various mechanisms varies according to the concentration of apoptotic agent, the time of incubation and cell type.

Jurkat cells treated with PA responded by increased expression of insulin receptor and GLUT-4. Resting T-lymphocytes, unlike monocytes, exhibit low levels of insulin receptor and GLUT-4, being non-responsive to insulin. However, upon activation by immunomodulators such as phytohemagglutinin (PHA), insulin receptor expression is increased in lymphocytes (46-48). The response of Jurkat cells incubated in the presence of PA was to increase their abundance of IR and GLUT-4. These findings suggest that insulin may protect Jurkat cells against the apoptotic effect of PA. We found similar results in human lymphocytes. The expression of insulin receptor and GLUT-4 were strongly correlated with DNA fragmentation. Stentz and Kitabchi (49) have also demonstrated that PA induced the expression/translocation of IR and GLUT-4 to the plasma membrane of human lymphocytes and human aortic endothelial cell lineage cells (HAEC). HAEC cells are also insulin insensitive presenting low expression levels of IR and GLUT-4. The authors used a relatively high dose of $\mathrm{PA}, 500 \mu \mathrm{M}$, which is known to be highly toxic for both Jurkat cells and human lymphocytes $(50,51)$.

PA itself increased the level of phosphorylated Akt. This observation suggests that PA can activate an alternative signaling pathway resulting in Akt 
phosphorylation (perhaps PKC, $(52,53)$. Sweeney et al (54) observed that exogenous delivery of phosphatidylinositol $(3,4,5)$-trisphosphate causes translocation of GLUT-4 from the cytosol to plasma membrane of muscle and fat cells, mimicking the response to insulin. However, Russell et al (55) reported an increase of GLUT-4 content in rat ventricular papillary muscle during hypoxia which was dependent on a PI3K independent pathway. These authors observed an increase in AMP-activated protein kinase (AMPK) activity and administration of the AMPK activating agent, AICAR, stimulated glucose uptake. On the other hand, administration of a PI3K inhibitor, wortmannin, did not affect the translocation of GLUT-4. These results suggest that the translocation of GLUT-4 to plasma membrane is activated by many different stimuli and pathways.

In order to verify whether the increase in IR and GLUT-4 abundance in Jurkat cells resulted in increased flux of substrates through the glycolytic pathway, glucose uptake was measured. Glucose consumption was increased by PA treatment in a concentration dependent fashion. Insulin had no additional effect on glucose uptake induced by PA. Glucose is readily utilized by lymphocytes as it is used for generation of ATP and a carbon source for macromolecule biosynthesis. Activation of leukocytes is associated with increased glucose utilization due to enhanced expression of glucose transporters (56). Treatment of Jurkat cells with CD95 antibodies resulted in apoptotic cell death through activation of $\operatorname{TNF}$ family receptor $(57,58)$ and lowered glucose transport activity (59). In addition to the increase in glucose uptake, we demonstrated in this work that glucose oxidation was decreased and the carbon backbone was deviated to synthesis of lipid macromolecules: triacylglycerol, phospholipids and cholesterol esters in PA treated Jurkat cells. 
By stimulation of biosynthetic pathways glucose may provide the means to avoid PA dependent toxic effects. Independent studies have compared the effects of oleic acid and PA on Chinese hamster ovary (60), pancreatic islet cells (61) and HepG2 hepatocyte line cell (62). Oleic acid presented the lowest cytotoxicity and its incorporation into triglyceride fraction was more effective. This result corroborates with the proposition that fatty acid conversion into triglyceride can reduce its cytotoxicity. However, this cell protection mechanism is ineffective when excessive amounts of fatty acids are given so exceeding the capacity to be incorporated into triglycerides.

Previous studies have shown that insulin and glucose metabolism act to protect against cell death. lida et al (22) observed that insulin can protect THP-1 cells, a human monocytic cell line, from cell apoptosis induced by starvation. The protection of these cells was related to the up regulation of the antiapoptotic protein Bcl-xL. Muller et al (23) showed that insulin secreted by MIN6 cells (an insulin-secreting cell line), in response to elevated glucose exerts autocrine effects to protect against apoptosis and stimulate cell proliferation. Zhao et al (24) have observed that the pro-apoptotic protein Puma (p53 upregulated modulator of apoptosis) activation is metabolically regulated in TLymphocyte cells. Glucose deprivation led to activation of this protein. Increased glucose metabolism suppressed p53-mediated Puma induction and attenuated cell death after growth factor withdrawal, whereas decreased glucose promoted p53-mediated Puma induction.

Taken as a whole, PA treatment activated several death signaling pathways (release of cytochrome c and activation of caspases 3 and 9 and MAPK proteins $\mathrm{p}-38$, JNK and ERK) that lead to lymphocyte apoptosis. We 
suggest that, in an attempt to survive, lymphocytes activate insulin signaling pathways and glucose utilization in response to PA so stimulating the synthesis of lipid macromolecules (triglycerides, phospholipids and cholesterol esthers) therefore removing PA from mediating intracellular cytotoxic effects. However, in the presence of high concentrations of PA, apoptotic mechanisms prevail and the cells die.

\section{Acknowledgments}

We are grateful to Drs. Rolando B. Ceddia, Leonardo S. dos Reis, Thais M. Lima and Elaine Hatanaka for their commentaries and to Jose Roberto Mendonça and Geraldina de Souza for technical assistance.

\section{REFERENCES}

1. Newton, K., and Strasser, A. 2000. Cell death control in lymphocytes. Adv Immunol 76:179-226.

2. Marsden, V. S., and Strasser, A. 2003. Control of apoptosis in the immune system: Bcl-2, BH3-only proteins and more. Annu Rev Immunol 21:71-105.

3. Newton, K., Kurts, C., Harris, A. W., and Strasser, A. 2001. Effects of a dominant interfering mutant of FADD on signal transduction in activated T cells. Curr Biol 11:273-276.

4. Opferman, J. T. 2008. Apoptosis in the development of the immune system. Cell Death Differ 15:234-242.

5. Porter, B. O., and Malek, T. R. 1999. Prostaglandin E2 inhibits T cell activation-induced apoptosis and Fas-mediated cellular cytotoxicity by blockade of Fas-ligand induction. Eur J Immunol 29:2360-2365. 
6. Rathmell, J. C., and Thompson, C. B. 2002. Pathways of apoptosis in lymphocyte development, homeostasis, and disease. Cell 109 Suppl:S97-107.

7. Aggarwal, B. B. 2003. Signalling pathways of the TNF superfamily: a double-edged sword. Nat Rev Immunol 3:745-756.

8. Mak, T. W., and Yeh, W. C. 2002. Signaling for survival and apoptosis in the immune system. Arthritis Res 4 Suppl 3:S243-252.

9. Salvesen, G. S., and Duckett, C. S. 2002. IAP proteins: blocking the road to death's door. Nature reviews 3:401-410.

10. Thornberry, N. A., and Lazebnik, Y. 1998. Caspases: enemies within. Science 281:1312-1316.

11. Yang, J., Liu, X., Bhalla, K., Kim, C. N., Ibrado, A. M., Cai, J., Peng, T. I., Jones, D. P., and Wang, X. 1997. Prevention of apoptosis by Bcl-2: release of cytochrome $\mathrm{c}$ from mitochondria blocked. Science 275:1129-1132.

12. Li, P., Nijhawan, D., Budihardjo, I., Srinivasula, S. M., Ahmad, M., Alnemri, E. S., and Wang, X. 1997. Cytochrome $\mathrm{c}$ and dATP-dependent formation of Apaf-1/caspase-9 complex initiates an apoptotic protease cascade. Cell 91:479-489.

13. Guo, W., Wong, S., Xie, W., Lei, T., and Luo, Z. 2007. Palmitate modulates intracellular signaling, induces endoplasmic reticulum stress, and causes apoptosis in mouse 3T3-L1 and rat primary preadipocytes. Am J Physiol Endocrinol Metab 293:E576-586.

14. Listenberger, L. L., Ory, D. S., and Schaffer, J. E. 2001. Palmitate-induced apoptosis can occur through a ceramide-independent pathway. J Biol Chem 276:14890-14895.

15. Chai, W., and Liu, Z. 2007. p38 mitogen-activated protein kinase mediates palmitate-induced apoptosis but not inhibitor of nuclear factor-kappaB 
degradation in human coronary artery endothelial cells. Endocrinology 148:1622-1628.

16. Newsholme, P., Curi, R., Pithon Curi, T. C., Murphy, C. J., Garcia, C., and Pires de Melo, M. 1999. Glutamine metabolism by lymphocytes, macrophages, and neutrophils: its importance in health and disease. $J$ Nutr Biochem 10:316-324.

17. Gould, G. W., and Holman, G. D. 1993. The glucose transporter family: structure, function and tissue-specific expression. Biochem J 295 ( Pt 2): 329-341.

18. Chakrabarti, R., Jung, C. Y., Lee, T. P., Liu, H., and Mookerjee, B. K. 1994. Changes in glucose transport and transporter isoforms during the activation of human peripheral blood lymphocytes by phytohemagglutinin. J Immunol 152:2660-2668.

19. Goodman, D. W., and Isakson, P. C. 1993. Mitogen activation of resting lymphocytes exposes cryptic insulin receptors. J Biol Chem 268:4207-4215.

20. Stentz, F. B., and Kitabchi, A. E. 2004. De novo emergence of growth factor receptors in activated human CD4+ and CD8+ T lymphocytes. Metabolism 53:117-122.

21. Maratou, E., Dimitriadis, G., Kollias, A., Boutati, E., Lambadiari, V., Mitrou, P., and Raptis, S. A. 2007. Glucose transporter expression on the plasma membrane of resting and activated white blood cells. Eur J Clin Invest $37: 282-290$.

22. lida, K. T., Suzuki, H., Sone, H., Shimano, H., Toyoshima, H., Yatoh, S., Asano, T., Okuda, Y., and Yamada, N. 2002. Insulin inhibits apoptosis of macrophage cell line, THP-1 cells, via phosphatidylinositol-3-kinasedependent pathway. Arterioscler Thromb Vasc Biol 22:380-386.

23. Muller, D., Jones, P. M., and Persaud, S. J. 2006. Autocrine anti-apoptotic 
and proliferative effects of insulin in pancreatic beta-cells. FEBS Lett 580:6977-6980.

24. Zhao, Y., Coloff, J. L., Ferguson, E. C., Jacobs, S. R., Cui, K., and Rathmell, J. C. 2008. Glucose metabolism attenuates p53 and Pumadependent cell death upon growth factor deprivation. J Biol Chem 283:36344-36353.

25. Wood, T. E., Dalili, S., Simpson, C. D., Hurren, R., Mao, X., Saiz, F. S., Gronda, M., Eberhard, Y., Minden, M. D., Bilan, P. J., Klip, A., Batey, R. A., and Schimmer, A. D. 2008. A novel inhibitor of glucose uptake sensitizes cells to FAS-induced cell death. Mol Cancer Ther 7:3546-3555

26. Bradford, M. M. 1976. A rapid and sensitive method for the quantitation of microgram quantities of protein utilizing the principle of protein-dye binding. Analytical biochemistry 72:248-254.

27. Laemmli, U. K. 1970. Cleavage of structural proteins during the assembly of the head of bacteriophage T4. Nature 227:680-685.

28. Towbin, H., Staehelin, T., and Gordon, J. 1979. Electrophoretic transfer of proteins from polyacrylamide gels to nitrocellulose sheets: procedure and some applications. Proceedings of the National Academy of Sciences of the United States of America 76:4350-4354.

29. Folch, J., Lees, M., and Sloane Stanley, G. H. 1957. A simple method for the isolation and purification of total lipides from animal tissues. $J$ Biol Chem 226:497-509.

30. Abushufa, R., Reed, P., and Weinkove, C. 1994. Fatty acids in erythrocytes measured by isocratic HPLC. Clin Chem 40:1707-1712.

31. Chipuk, J. E., Bouchier-Hayes, L., and Green, D. R. 2006. Mitochondrial outer membrane permeabilization during apoptosis: the innocent bystander scenario. Cell death and differentiation 13:1396-1402. 
32. Garrido, C., Galluzzi, L., Brunet, M., Puig, P. E., Didelot, C., and Kroemer, G. 2006. Mechanisms of cytochrome $\mathrm{c}$ release from mitochondria. Cell death and differentiation 13:1423-1433.

33. Kroemer, G., Dallaporta, B., and Resche-Rigon, M. 1998. The mitochondrial death/life regulator in apoptosis and necrosis. Annu Rev Physiol 60:619-642.

34. Green, D. R., and Reed, J. C. 1998. Mitochondria and apoptosis. Science 281:1309-1312.

35. Cury-Boaventura, M. F., Gorjao, R., de Lima, T. M., Newsholme, P., and Curi, R. 2006. Comparative toxicity of oleic and linoleic acid on human lymphocytes. Life Sci 78:1448-1456.

36. Cury-Boaventura, M. F., Pompeia, C., and Curi, R. 2004. Comparative toxicity of oleic acid and linoleic acid on Jurkat cells. Clin Nutr 23:721-732.

37. Zou, H., Li, Y., Liu, X., and Wang, X. 1999. An APAF-1.cytochrome c multimeric complex is a functional apoptosome that activates procaspase-9. J Biol Chem 274:11549-11556.

38. Cohen, G. M. 1997. Caspases: the executioners of apoptosis. Biochem J 326 ( Pt 1):1-16.

39. Pearson, G., Robinson, F., Beers Gibson, T., Xu, B. E., Karandikar, M., Berman, K., and Cobb, M. H. 2001. Mitogen-activated protein (MAP) kinase pathways: regulation and physiological functions. Endocr Rev 22:153-183.

40. Ogino, T., Ozaki, M., Hosako, M., Omori, M., Okada, S., and Matsukawa, A. 2009. Activation of c-Jun N-terminal kinase is essential for oxidative stress-induced Jurkat cell apoptosis by monochloramine. Leuk Res 33:151-158.

41. Lee, S. H., Park, S. W., Pyo, C. W., Yoo, N. K., Kim, J., and Choi, S. Y. 
2009. Requirement of the JNK-associated Bcl-2 pathway for human lactoferrin-induced apoptosis in the Jurkat leukemia T cell line. Biochimie 91:102-108.

42. Cacicedo, J. M., Benjachareowong, S., Chou, E., Ruderman, N. B., and Ido, Y. 2005. Palmitate-induced apoptosis in cultured bovine retinal pericytes: roles of $\mathrm{NAD}(\mathrm{P}) \mathrm{H}$ oxidase, oxidant stress, and ceramide. Diabetes 54:1838-1845.

43. Wu, H., Ichikawa, S., Tani, C., Zhu, B., Tada, M., Shimoishi, Y., Murata, Y., and Nakamura, Y. 2009. Docosahexaenoic acid induces ERK1/2 activation and neuritogenesis via intracellular reactive oxygen species production in human neuroblastoma SH-SY5Y cells. Biochim Biophys Acta 1791:8-16.

44. Bosca, L., Zeini, M., Traves, P. G., and Hortelano, S. 2005. Nitric oxide and cell viability in inflammatory cells: a role for NO in macrophage function and fate. Toxicology 208:249-258.

45. Merrill, A. H., Jr. 2002. De novo sphingolipid biosynthesis: a necessary, but dangerous, pathway. J Biol Chem 277:25843-25846.

46. Brown, T. J., Ercolani, L., and Ginsberg, B. H. 1983. Properties and regulation of the T lymphocyte insulin receptor. $J$ Recept Res 3:481-494.

47. Brown, T. J., Ercolani, L., and Ginsberg, B. H. 1985. Demonstration of receptors for insulin-like growth factor-II on human T-lymphocytes. $J$ Recept Res 5:297-309.

48. Buffington, C. K., el-Shiekh, T., Kitabchi, A. E., and Matteri, R. 1986. Phytohemagglutinin (PHA) activated human T-lymphocytes: concomitant appearance of insulin binding, degradation and insulin-mediated activation of pyruvate dehydrogenase (PDH). Biochem Biophys Res Commun 134:412-419.

49. Stentz, F. B., and Kitabchi, A. E. 2006. Palmitic acid-induced activation of 
human T-lymphocytes and aortic endothelial cells with production of insulin receptors, reactive oxygen species, cytokines, and lipid peroxidation. Biochem Biophys Res Commun 346:721-726.

50. Gorjao, R., Cury-Boaventura, M. F., de Lima, T. M., and Curi, R. 2007. Regulation of human lymphocyte proliferation by fatty acids. Cell Biochem Funct 25:305-315.

51. Lima, T. M., Kanunfre, C. C., Pompeia, C., Verlengia, R., and Curi, R. 2002. Ranking the toxicity of fatty acids on Jurkat and Raji cells by flow cytometric analysis. Toxicol In Vitro 16:741-747.

52. Bauer, B., and Baier, G. 2002. Protein kinase $C$ and AKT/protein kinase B in CD4+ T-lymphocytes: new partners in TCR/CD28 signal integration. Mol Immunol 38:1087-1099.

53. Bauer, B., Krumbock, N., Fresser, F., Hochholdinger, F., Spitaler, M., Simm, A., Uberall, F., Schraven, B., and Baier, G. 2001. Complex formation and cooperation of protein kinase $C$ theta and Akt1/protein kinase B alpha in the NF-kappa B transactivation cascade in Jurkat T cells. J Biol Chem 276:31627-31634.

54. Sweeney, G., Garg, R. R., Ceddia, R. B., Li, D., Ishiki, M., Somwar, R., Foster, L. J., Neilsen, P. O., Prestwich, G. D., Rudich, A., and Klip, A. 2004. Intracellular delivery of phosphatidylinositol $(3,4,5)$-trisphosphate causes incorporation of glucose transporter 4 into the plasma membrane of muscle and fat cells without increasing glucose uptake. $J$ Biol Chem 279:32233-32242.

55. Russell, R. R., 3rd, Bergeron, R., Shulman, G. I., and Young, L. H. 1999. Translocation of myocardial GLUT-4 and increased glucose uptake through activation of AMPK by AICAR. Am J Physiol 277:H643-649.

56. Calder, P. C., Dimitriadis, G., and Newsholme, P. 2007. Glucose metabolism in lymphoid and inflammatory cells and tissues. Curr Opin Clin Nutr Metab Care 10:531-540. 
57. Oehm, A., Behrmann, I., Falk, W., Pawlita, M., Maier, G., Klas, C., LiWeber, M., Richards, S., Dhein, J., Trauth, B. C., and et al. 1992. Purification and molecular cloning of the APO-1 cell surface antigen, a member of the tumor necrosis factor/nerve growth factor receptor superfamily. Sequence identity with the Fas antigen. $J$ Biol Chem 267:10709-10715.

58. Alderson, M. R., Tough, T. W., Braddy, S., Davis-Smith, T., Roux, E., Schooley, K., Miller, R. E., and Lynch, D. H. 1994. Regulation of apoptosis and $\mathrm{T}$ cell activation by Fas-specific mAb. Int Immunol 6:1799-1806.

59. Berridge, M. V., Tan, A. S., McCoy, K. D., Kansara, M., and Rudert, F. 1996. CD95 (Fas/Apo-1)-induced apoptosis results in loss of glucose transporter function. J Immunol 156:4092-4099.

60. Listenberger, L. L., Han, X., Lewis, S. E., Cases, S., Farese, R. V., Jr., Ory, D. S., and Schaffer, J. E. 2003. Triglyceride accumulation protects against fatty acid-induced lipotoxicity. Proceedings of the National Academy of Sciences of the United States of America 100:3077-3082.

61. Cnop, M., Hannaert, J. C., Hoorens, A., Eizirik, D. L., and Pipeleers, D. G. 2001. Inverse relationship between cytotoxicity of free fatty acids in pancreatic islet cells and cellular triglyceride accumulation. Diabetes 50:1771-1777.

62. Ricchi, M., Odoardi, M. R., Carulli, L., Anzivino, C., Ballestri, S., Pinetti, A., Fantoni, L. I., Marra, F., Bertolotti, M., Banni, S., Lonardo, A., Carulli, N., and Loria, P. 2009. Differential effect of oleic and palmitic acid on lipid accumulation and apoptosis in cultured hepatocytes. J Gastroenterol Hepatol. 


\section{FIGURE LEGENDS}

Figure 1: Effect of different concentrations of PA on DNA fragmentation of Jurkat cells cultured for 12 and 24 hours. ${ }^{*} p<0.05$ as compared to control; \# $p$ $<0.05$ when compared to respective $12 \mathrm{~h}$ period. Results are expressed as mean \pm S.E.M.

Figure 2: Effect of PA on mitochondria membrane depolarization. ${ }^{*} p<$ 0.05 when compared to control. Results are expressed as mean \pm S.E.M.

Figure 3: Analysis of A) cytochrome $c$ distribution and B) caspases 3 and 9 activation after $24 \mathrm{~h}$ incubation with PA by immunoblotting.

Figure 4: Analysis of JNK-1/2, p38 and ERK-1/2 activation after 24h incubation with PA by immunoblotting.

Figure 5: Effect of different concentrations and of PA on A) IR abundance and B) GLUT-4 in 12 and 24 hours incubated cell. ${ }^{*} p<0.05$ as compared to control. $* p<0.05$ as compared to respective $12 \mathrm{~h}$ period. Results are expressed as mean of fluorescence $(\mathrm{MFI}) \pm$ S.E.M. Correlation graph between Jurkat cells with fragmented DNA (in percentage) and C) IR abundance and D) GLUT-4 abundance. $r^{2}$ values are indicated.

Figure 6: Effects of PA on A) human lymphocyte cells on DNA 
fragmentation, abundance of B) IR and C) GLUT-4. * $p<0.001$ when compared to control. Results are expressed as mean of fluorescence (MFI) \pm S.E.M.

Figure 7: Analysis of IR and GLUT-4 protein by immunoprecipitation after incubation with PA for $24 \mathrm{~h}$. p-IR protein was analyzed by immunoprecipitation (after $24 \mathrm{~h}$ incubation with PA, insulin $(10 \mathrm{mU} / \mathrm{mL})$ was added to cells for 30 minutes.

Figure 8: Effect of PA on A) glucose uptake and B) on glucose decarboxylation. * $p<0.05$ when compared to control. Results are expressed as mean \pm S.E.M.

Figure 9: Analysis of $\left[{ }^{14} \mathrm{C}\right]$-palmitate incorporation into different classes of lipid after $24 \mathrm{~h}$ incubation. Results are expressed as mean \pm S.E.M. 


\section{FIGURES}

FIGURE 1

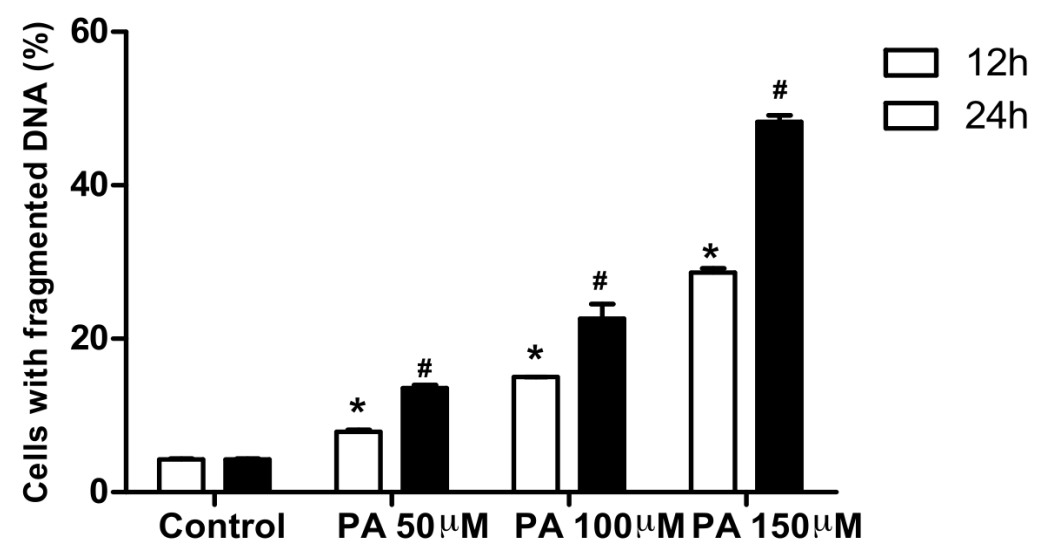

FIGURE 2

Mitochondrial Membrane Depolarization

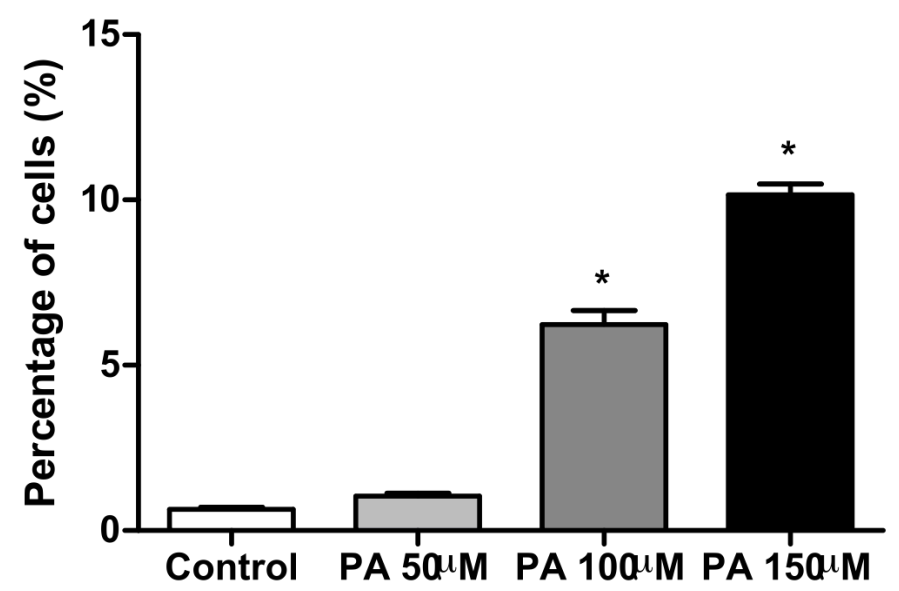

FIGURE 3

0

$50 \mu \mathrm{M} \quad 100 \mu \mathrm{M} \quad 150 \mu \mathrm{M}$

0

$50 \mu \mathrm{M}$

$100 \mu \mathrm{M} \quad 150 \mu \mathrm{M}$ 


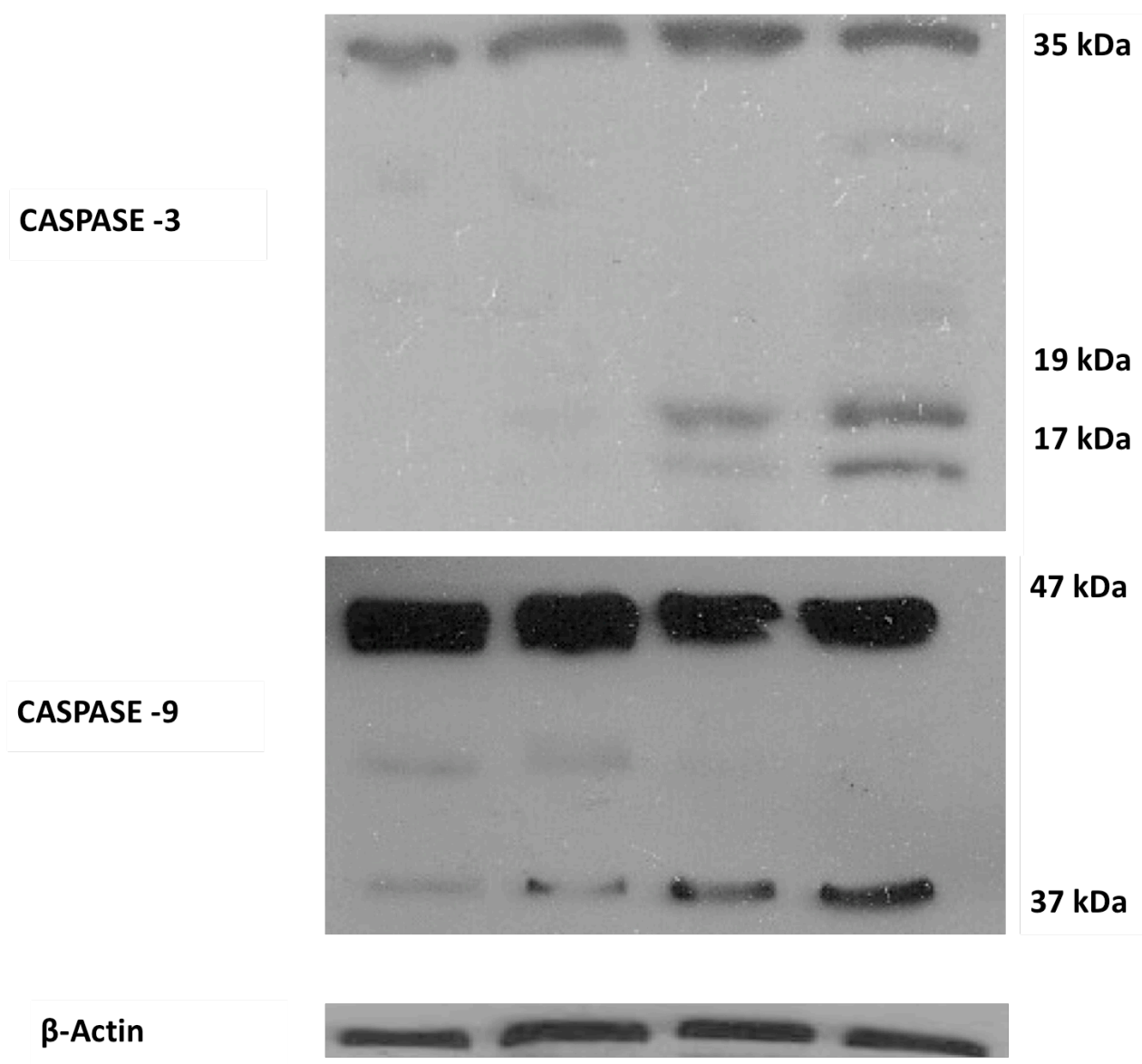


FIGURE 4

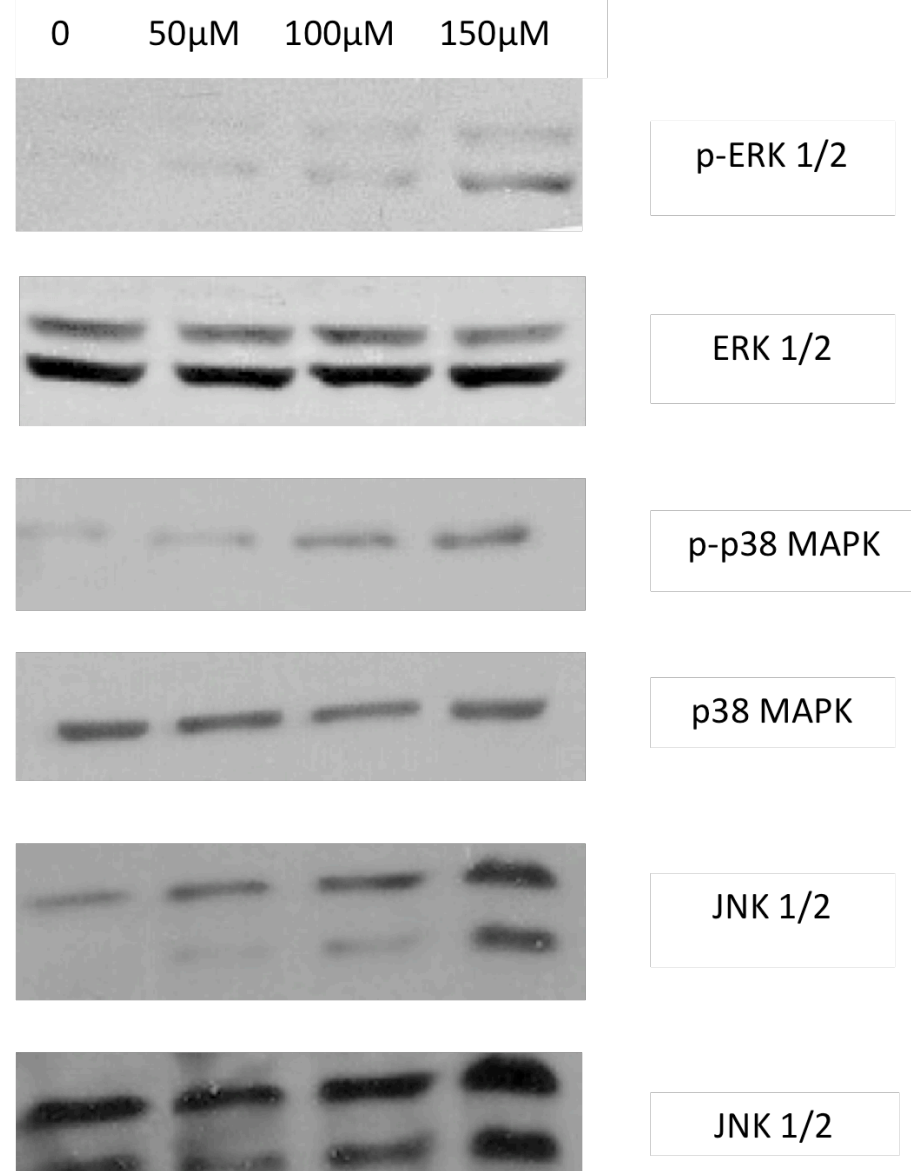


FIGURE 5
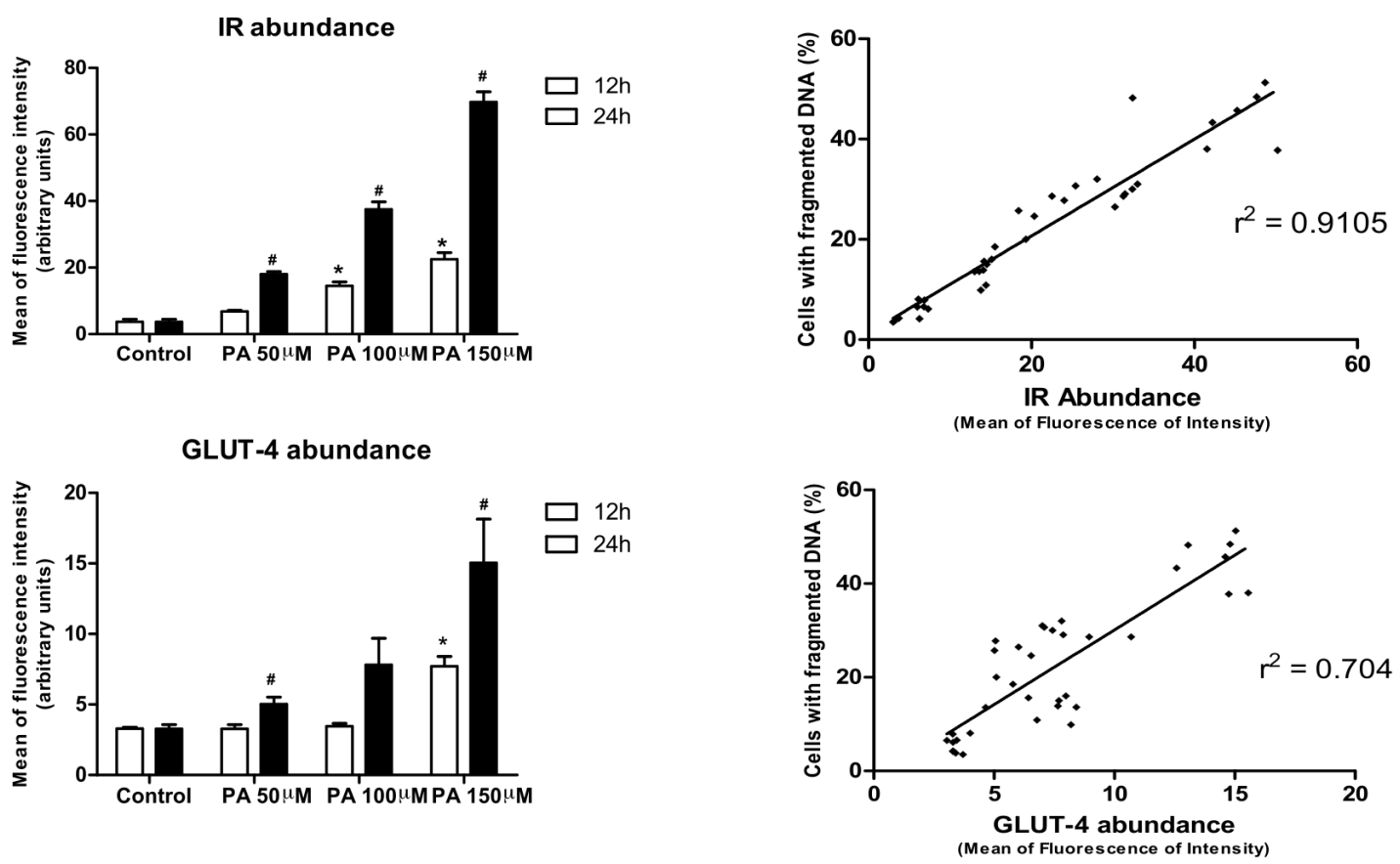

\section{FIGURE6}

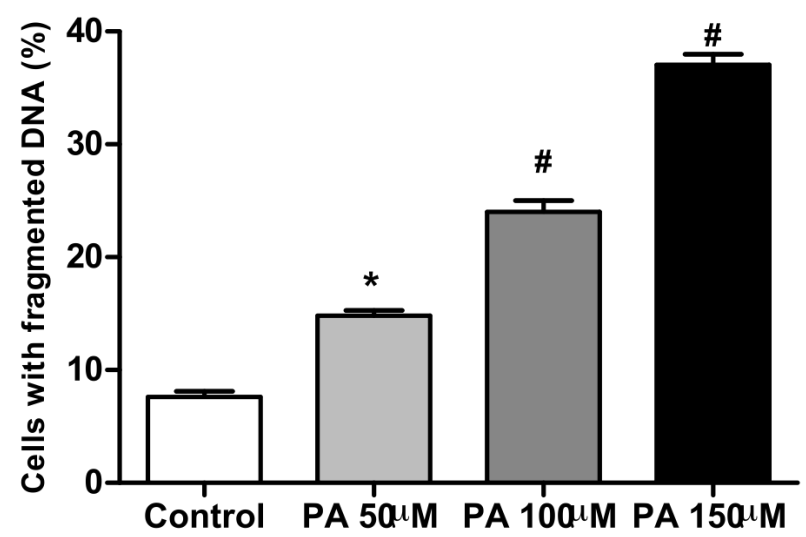



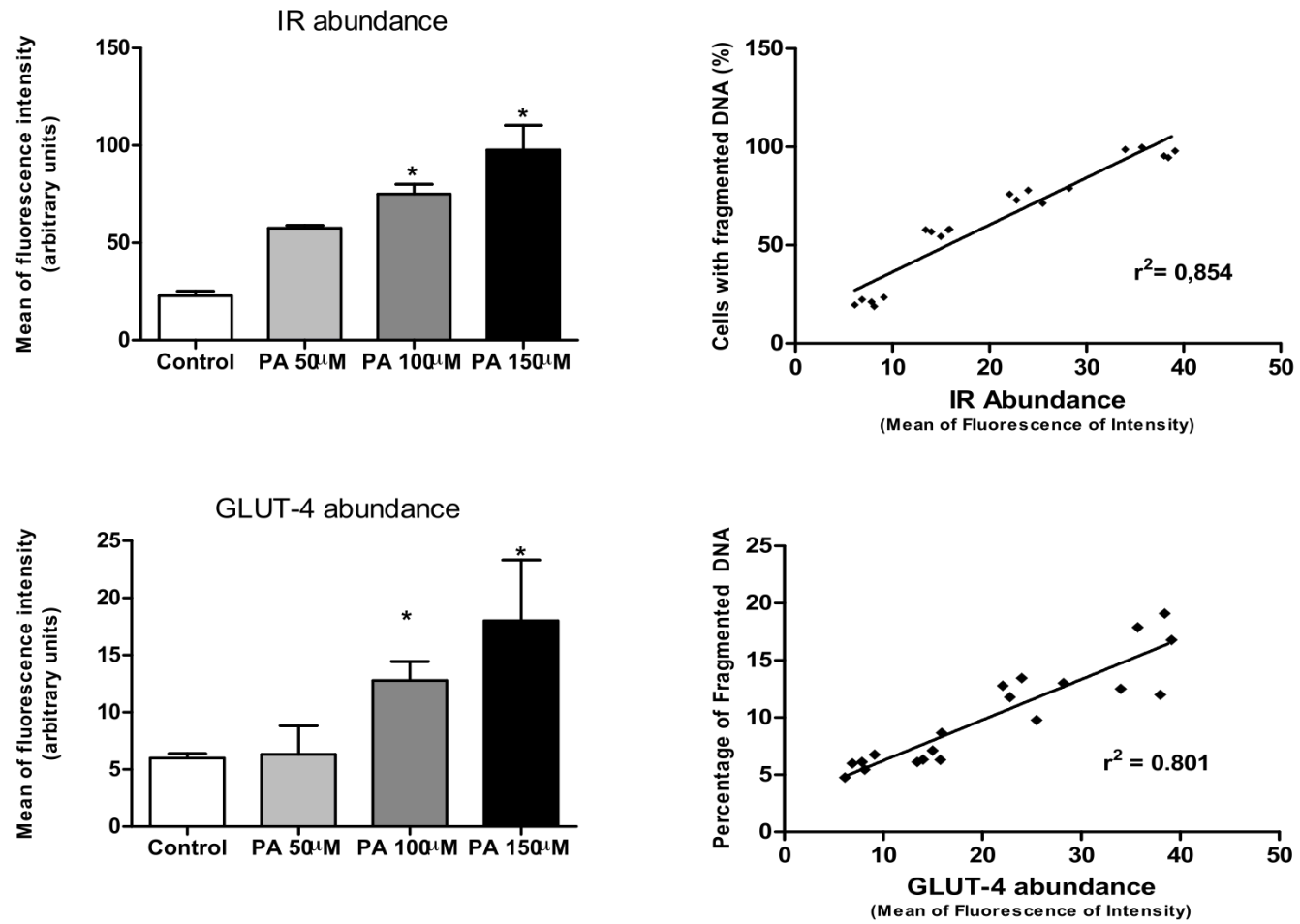

FIGURE 7 


\section{FIGURE 8}
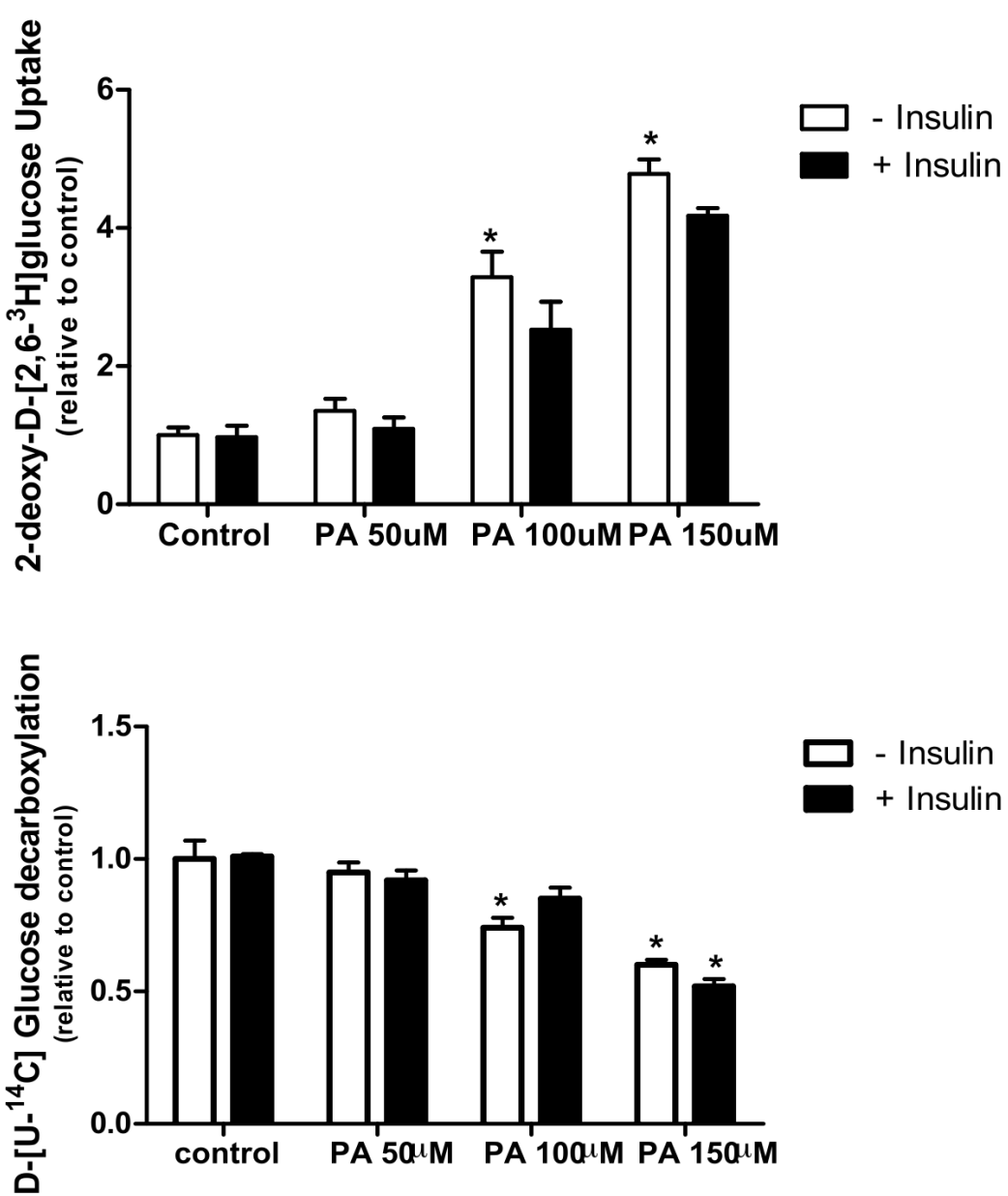


\section{FIGURE 9}
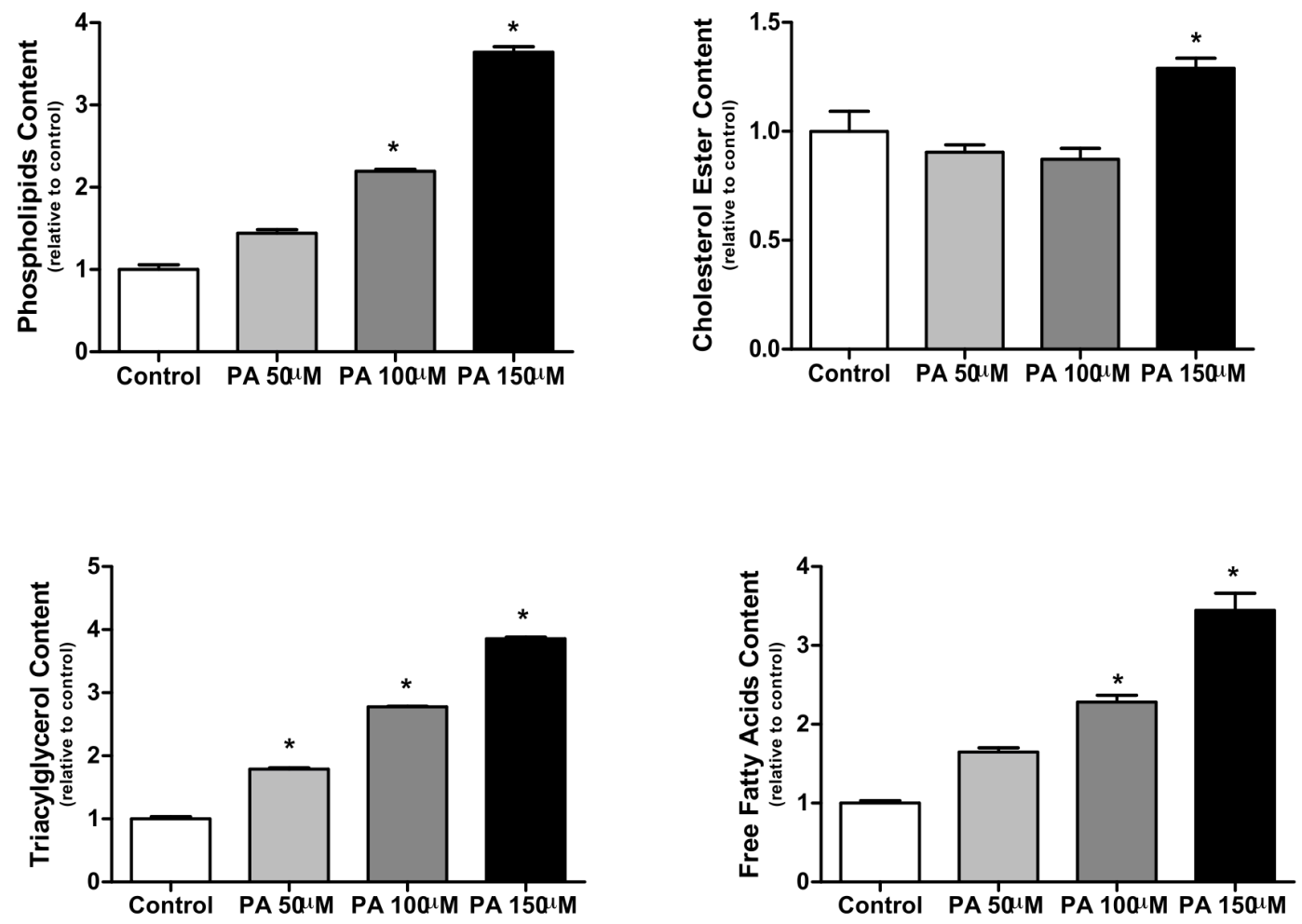